\title{
EIGHTY YEARS
}

\section{REMINISCENCES}
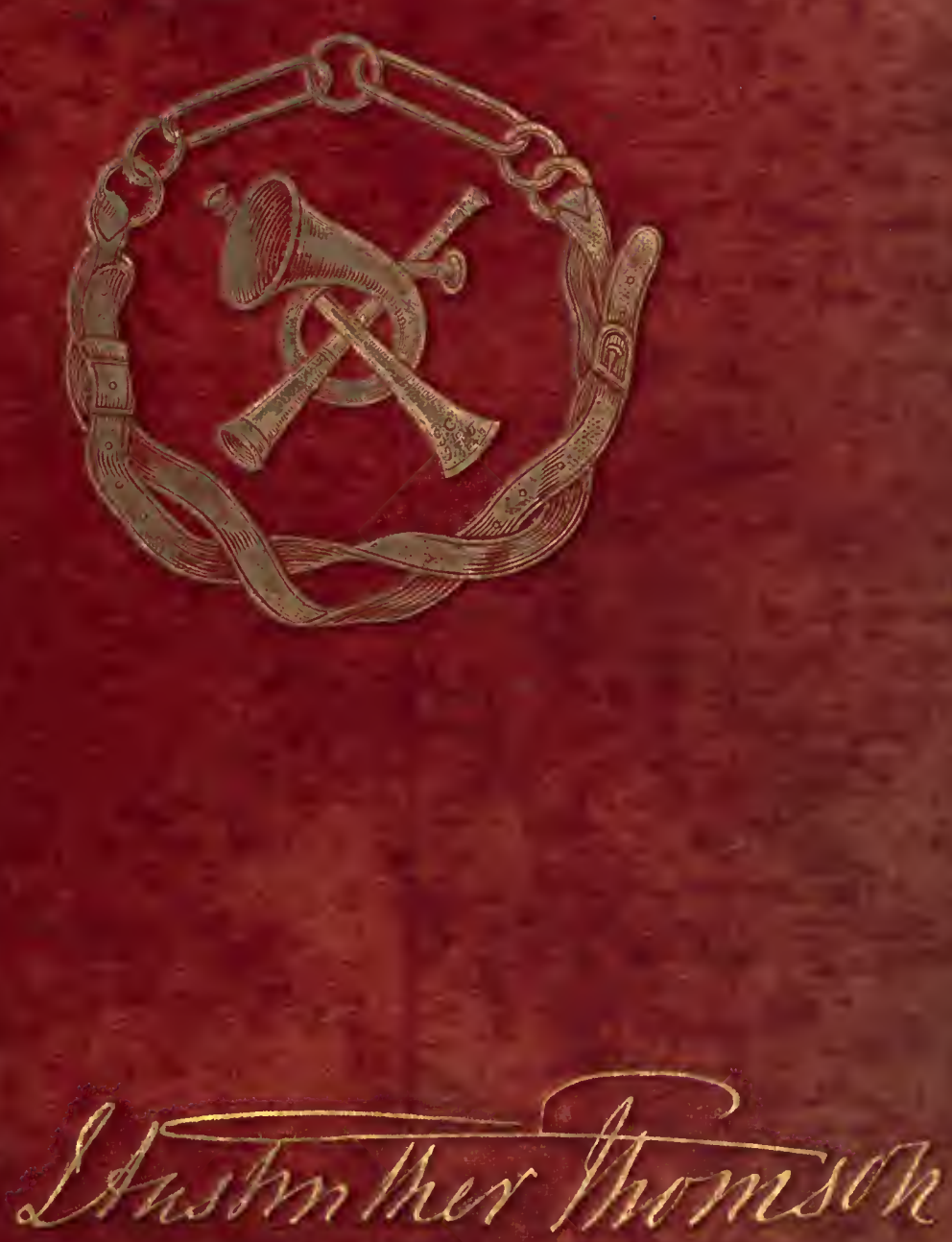
Ex Libris

C. K. OGDEN

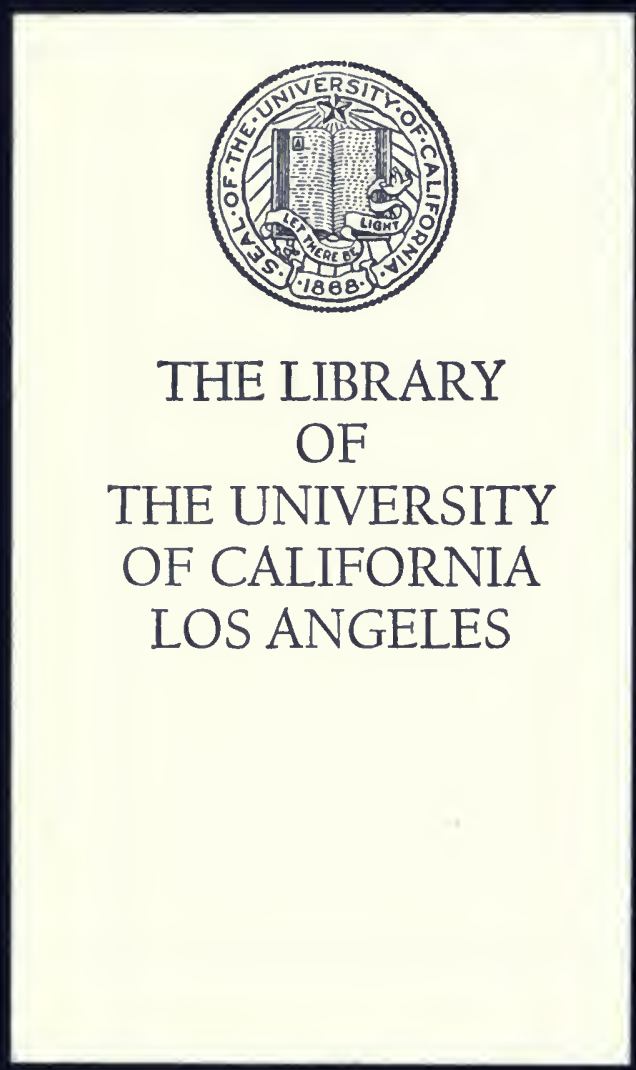


w 100

$$
946
$$


Weald A ale

1904. 

EIGHTY YEARS' REMINISCENCES 

Digitized by the Internet Archive in 2007 with funding from Microsoft Corporation 


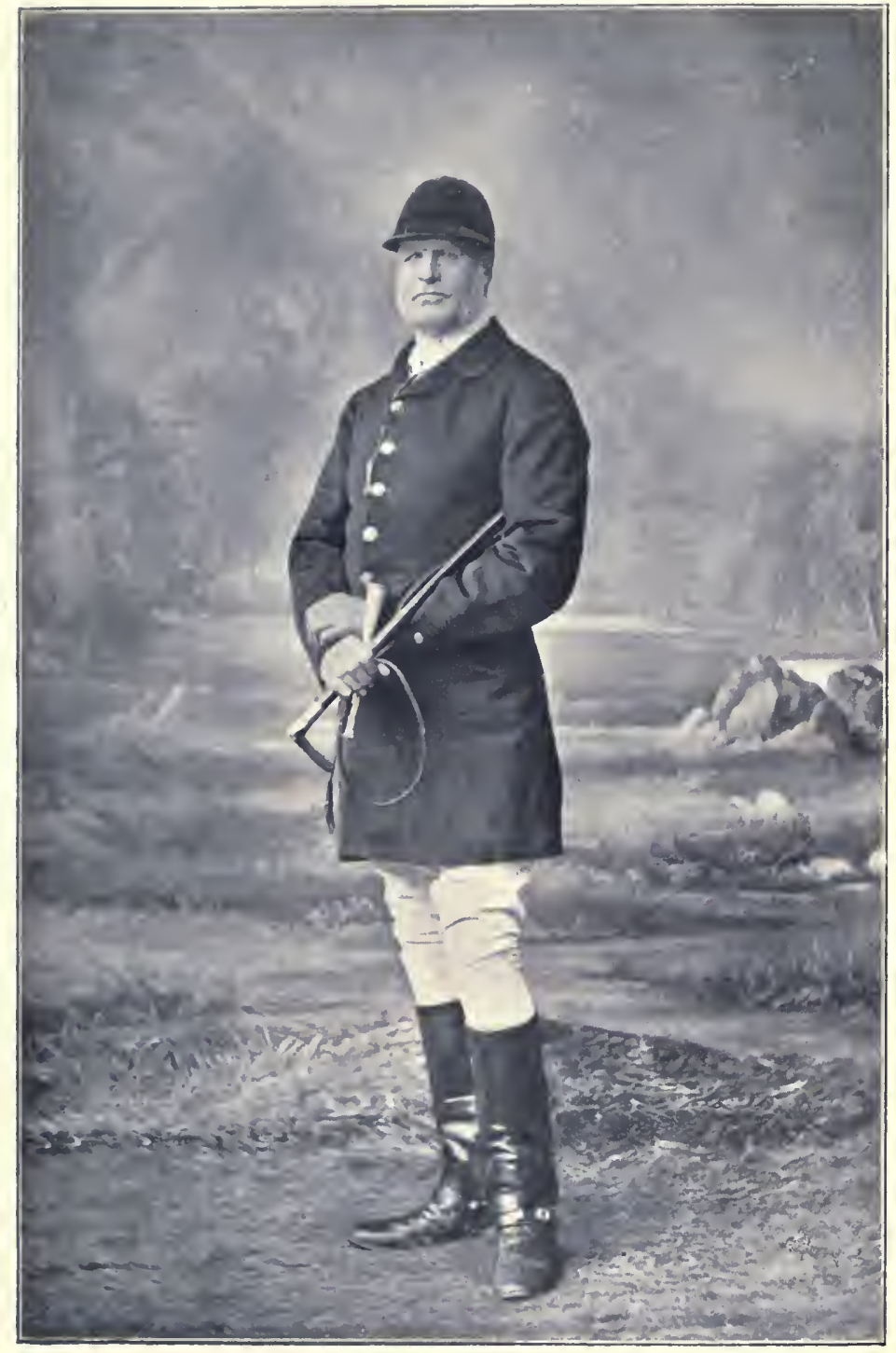

COLONEL J. AISTRUTHER THOMSON.

From a Photograph by G. I. Rodger, St. Anlrew's, 


\section{EIGHTY YEARS'}

\section{R E M I N I S C E N C E S}

BY

COLONEL ANSTRUTHER THOMSON

WITH ILLUSTRATIONS

. IN TWO VOLUMES. VOLUME I.

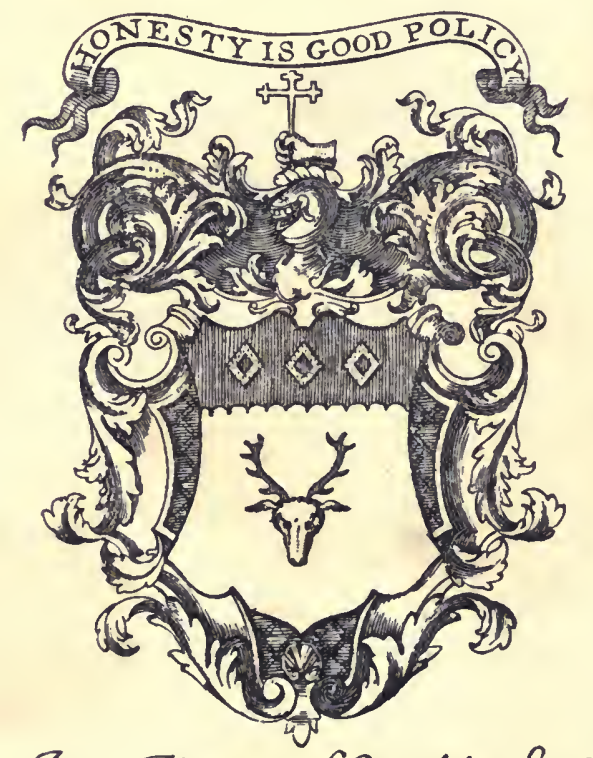

Sohn Thomson of Gharleton Gra:

LONGMANS, GREEN, AND CO.

39 PATERNOSTER ROW, LONDON NEW YORK AND BOMBAY 



\section{SK \\ 285 \\ A62A5 \\ V. 1}

To

\section{MY WIFE}

Whose ENERgy and PERSEVERANCE ENABLED ME TO COMPLETE

THESE REMINISCENCES 



\section{O N T E N T S}

CHAPTER

PAGE

I. The St. Clairs and Thomsons . . . . I

II. My Schooldays . $\quad$ - . $\quad$ - 5

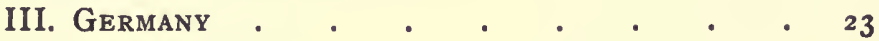

IV. 9TH Lancers . . . . . . . . 36

V. QueEn Victoria's Coronation • • . $\quad 52$

VI. Hampton Court and Dorchester . • . 70

VII. I3TH Light Dragoons • • • • $\quad$ • 85

VIII. Exeter and Ireland . • . • • . 106

IX. Atherstone: First Time . . . . . II7

X. FIFE : 1849 AND $185^{\circ}$. . . . . . 133

XI. Atherstone: Second Time, 1850 • • . I4I

XII. The Crimea . . . . . . . . 160

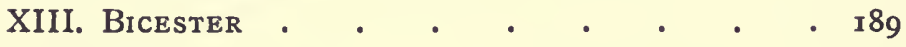

XIV. FIFE • • • • . . • • . 219

XV. The Fife Mounted Rifles • • • . 230

XVI. DeRbY DAY . . . . . . . 250

XVII. Henry Loch in China • . . . . 267

XVIII. Fife Election • • • • • • 295

XIX. Pytchley • • . . . . . . 312

XX. The Waterloo Run . • . . . . 344

XXI. Johan Erasmus Boehm, afterwards Sir EDGAR BOEHM . . . • . . 36I

XXII. Sale of Pytchley Horses and Leatham GRANGE • • • • • • $\quad 388$

APPENDIX . . . . . . . . . 4 4I7

VOL. I. $\quad b$ 



\section{LIST OF ILLUSTRATIONS}

Colonel J. Anstruther Thomson. From a Photograph by G. B. Rodger, St. Andrewes . . . . . . Frontispiece

Arms of John Thomson of Charleton, EsQ., $\mathrm{r}_{786}$. . . . . . Vignette on Title-page

Arms of James Thomson of Mildaine and Montrybo, r676. From Heralds' Office, Edinburgh . . . . . . Facing page I

Hon. Grizel St. Clair, Wife of John Paterson of Preston Hall. From an Oil Painting at Charleton . . " " 2

John Paterson of Preston Hall. From a Miniature Painting on Copper by Madame Vorelse at Charleton . . " " 4

Colonel John Anstruther, 62nd RegiMENT, I803. From a Painting by Martin at Charleton . . . . . . " , " 6

J. Anstruther Thomson, late M.F.H., 1807. From a Water-colour Painting by Douglas at Charleton . . . " " 8

Midnight March To LynN, 1842 . From a Water-colour Sketch by Soame Fenyns,

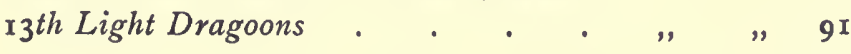


i3th Light Dragoons at Dublin, J. A. T. on "Dhroleen," I847. From a Watercolour Painting by Michael Angelo Hayes Facing page II 5

Badminton Group, 1857. Photographed at Badminton by Luigi Cella . . . " " 2II

JAMES, 3RD EARL of Rosslyn. From $a$ Painting at Dysart . . . . " " 2 " 219

John Anstruther Thomson of Charleton, 1830. From a Painting by Colvin Smith at Charleton. . . . . . " " 306

John Walker, Fife Hounds, I829-1848. From a Photograph, 1866 . . . " " 334

"Fresco." From a Pencil Sketch in possession of the late Tom Firr . . . . " " 34I

"Valeria." From a Painting by Corbet at Charleton . . . . . . " " 347

"Rainbow." From a Painting by Corbet at Charleton . . . . . . " " 350 TOM FIRR, ABOUT 1870. From a Photograph " " 356

\section{IN THE TEXT.}

Sketch of Balaclava Charge . . .

Plan of the Waterloo Run, 2ND Feb., 1866 



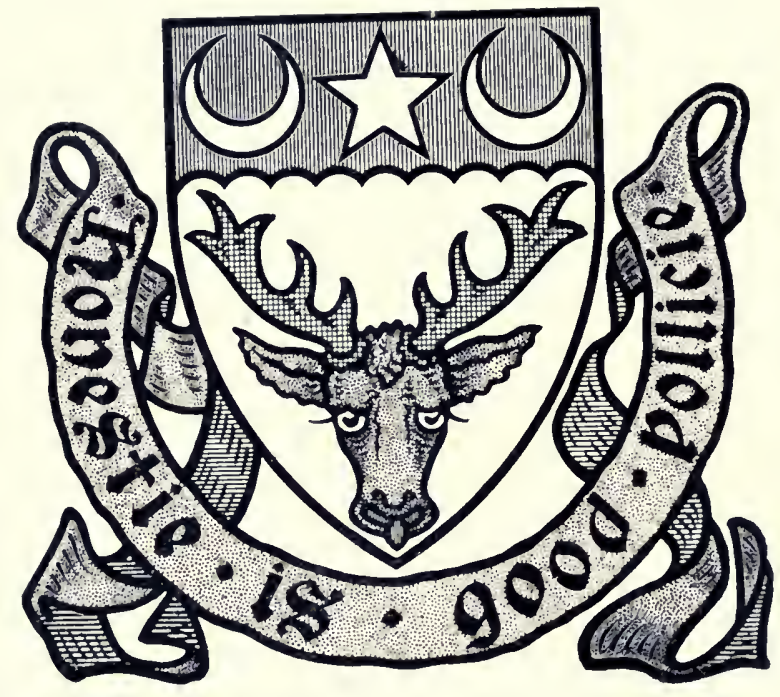

ARMS OF JAMES THOMSON OF MILDAINE AND MONTRYBO, 1676 . 


\section{ERRATA.}

Page 65, line 4 from bottom, for "Masters" read "Musters".

" 136, "13, for "wended" read "mended".

"156, "13, for "Maude "read "Mawe".

" 2ro, " 5 from bottom, for "Crafton " read "Grafton".

" 247, " I, for " 1862 " read " I86I".

" 250, " 9 from bottom, for "Rosslyn " read "Loughborough". 



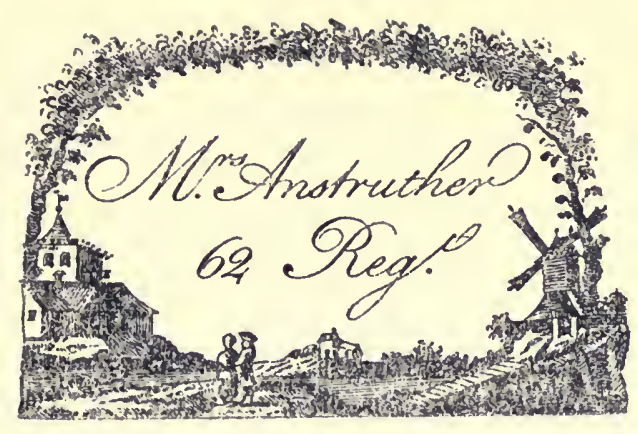

CHAPTER I.

THE ST. CLAIRS AND THOMSONS.

Henry St. Clair, eighth Lord Sinclair, married, in 1680, Grizel, daughter of Sir James Cockburn of Cockburn. He had two sons and two daughters. His eldest son, John, Master of Sinclair, never assumed the title, being attainted for taking part in the rising of 17 I 5 . He died in 1750 , leaving no issue, and was succeeded by his brother James, a distinguished General, who also died without issue.

Grizel, his eldest daughter, married John Paterson of Preston Hall, son of the Archbishop of Glasgow. John Paterson died in the Fleet Prison, I716, the day before he was to have been executed, having been concerned in the rising of I7 I5. He had one son, Colonel James Paterson St. Clair, who succeeded him, and one daughter, Margaret, who married, in 1744, John Thomson of Charleton. Colonel Paterson St. Clair dying without issue, his sister Margaret, wife of John Thomson of Charleton, became heirgeneral of the Lords Sinclair, and the estate of Dysart went to his cousin, Sir John Erskine of Alva, son of Catherine, second daughter of Henry, eighth VOL. I. 
Lord Sinclair, and he left all his personal property to my father.

James Thomson of Mildaine and Montrybo (Mildeans and Montrave) matriculated his arms about 1676. His eldest son, John, married, in 1709, Rachael, daughter of John Brymer of Edrom, in the county of Berwick. Her mother was Mary Bethune of Balfour. Their eldest daughter, Mary, married John Spottiswoode of Spottiswoode, Co. Berwick. In I I I 3 he bought the Barony of Charleton from Colonel John Hope. The barony consists of the farms of Laddedy, Newbigging of Charleton (now called Newbigging of Ceres), Newbigging of Craighall, Wilkieston and Gathercauld. $\mathrm{He}$ also was laird of the lands of Kilmany and Touch, which he left to his younger sons. His eldest son, John (who married Margaret Paterson), succeeded him, built the present house of Charleton about i 760, and then matriculated his arms again as Thomson of Charleton. The old house was called Newton, and was situated where the farm buildings now are. When it was pulled down the "flooring deals" were sent for cradling to the coal pits at Laddedy.

They had one son, John, who died at the age of eighteen, and two daughters-Rachel, married to Colonel John MacDonell, Younger of Lochgary, who died young without children, and Grizel, who married Colonel John Anstruther (my grandfather). Colonel Anstruther joined Wolfe's Regiment in 1756. He was afterwards Major in the 63rd Regiment and Colonel in the 62nd Regiment. He served 


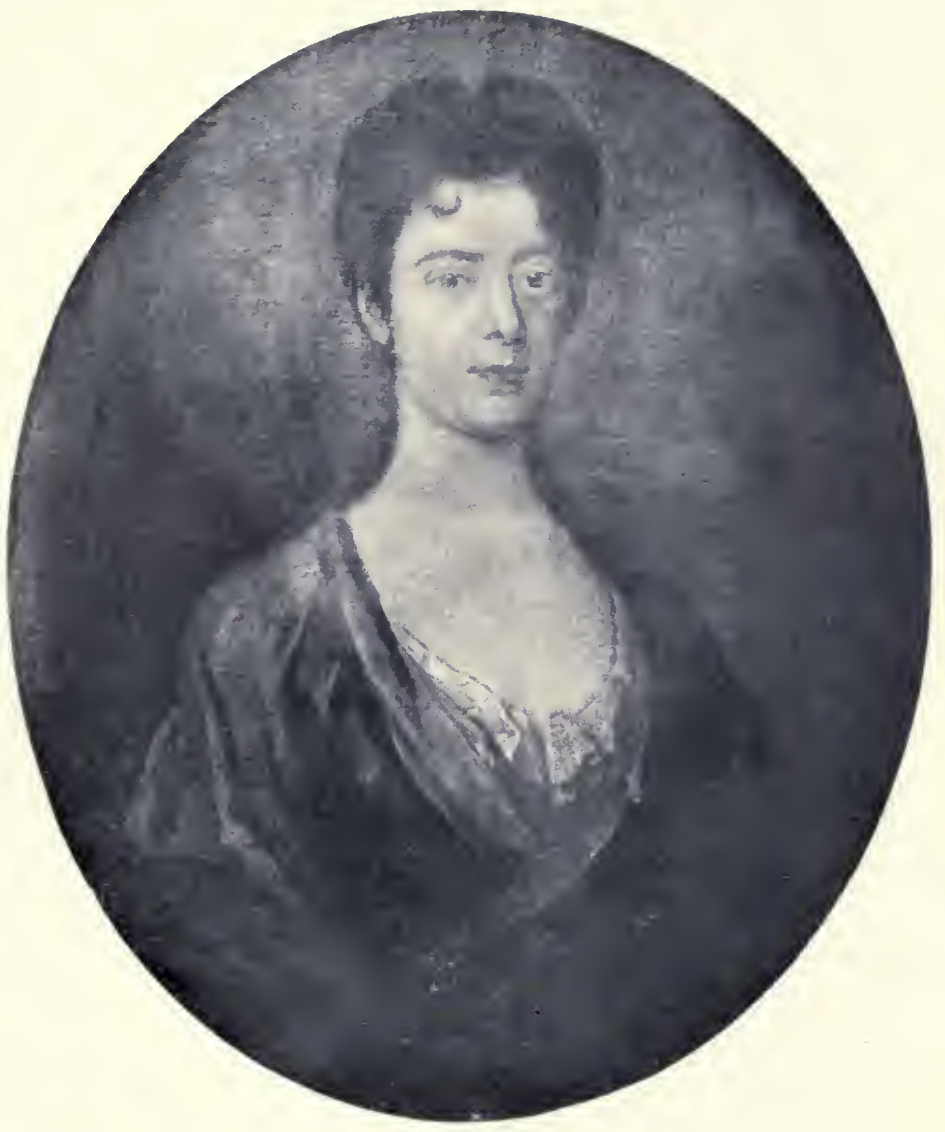

HON. GRIZEL ST. CLAIR, WIFE OF JOHN PATERSON OF PRESTON HALL. 

in the American War in General Burgoyne's division in 1777 , was taken prisoner and twice wounded. When he retired from the army he sold his commission for $£ 8,000$, and bought the farm of Coates, near Charleton, and during the latter part of his life lived at Coates House with his two daughters, Margaret and Catherine. Margaret married General Durham of Largo.

John Thomson of Charleton, not having given his consent to his daughter's marriage, took care that Colonel Anstruther should have no benefit, and left the Charleton property to his grandson, my father. $\mathrm{He}$ also put into his will that any one succeeding to Balcaskie should forfeit Charleton, and that in case of my father dying without an heir, Charleton should go to the second son of John Spottiswoode of Spottiswoode.

My father was the eldest son of John Anstruther, second son of Sir Robert Anstruther of Balcaskie, and took the name of Thomson on succeeding to the estate of Charleton on the death of his mother. $\mathrm{He}$ was born in 1776, and succeeded to Charleton in I797. He raised a troop of the Fife Fencible Cavalry, of which regiment his father was Colonel. When they were disbanded the colours were sent to Charleton, where they now are.

In I 800 he became Major of the Fife Yeomanry, their Colonel being Morrison of Naughton, to whom my father succeeded in command in 1807 . He was Master of Hounds for three years (1803-1 806), the kennels being at Charleton. He gave the hounds to 
the county on retiring from the mastership, and they were the origin of the Fife pack.

My father married, in 1807 , Clementina, daughter of the Right Honourable William Adam of Blair Adam, Baron of Exchequer, and of the Hon. Eleanora Elphinstone, sister to Lord Keith. He had five daughters and two sons, of which I was the elder.

\section{Old Fife Yeomanty Song, Written during the PENINSUlaR WaR.}

\section{CORNEL TAMSON.}

Come a' ye jolly Britons, I pray you lend an ear;

Cheer up your noble courages and enter Volunteers ;

Come, enter Volunteers, brave boys, and fight for your Queen, And when we are returned, in whisky we will swim.

We're the Light Horse of Fifeshire, sae merrily we'll go Along with Cornel Tamson, that valiant hero.

Our coats they are of blue, brave boys, our jackets are of red, A glittering cap and feathers we wear upon our head;

A noble horse to ride upon; ten guineas in advance;

And sae merrily we'll go, brave boys, we'll lay the pride of France.

We're the Light Horse of Fifeshire, etc.

And now the time is come, brave boys, when we must cross the seas ;

We'll fight both France and Flanders and foreign countries With glittering swords and pistols : we'll do the best we can, And make the Frenchmen tremble when they see a Fifeshireman.

We're the Light Horse of Fifeshire, etc.

And when the wars are ended, and God spare our lives, We'll bring vast sums of money to our sweethearts and our wives ; We'll push about the flowing bowl, successes we will singHere's a health to Cornel Tamson and all his valiant men : We'll push about the flowing bowl, successes we will singHere's a health to Cornel Tamson and God save the King.

We're the Light Horse of Fifeshire, sae merrily we'll go Along with Cornel Tamson, that valiant hero. 


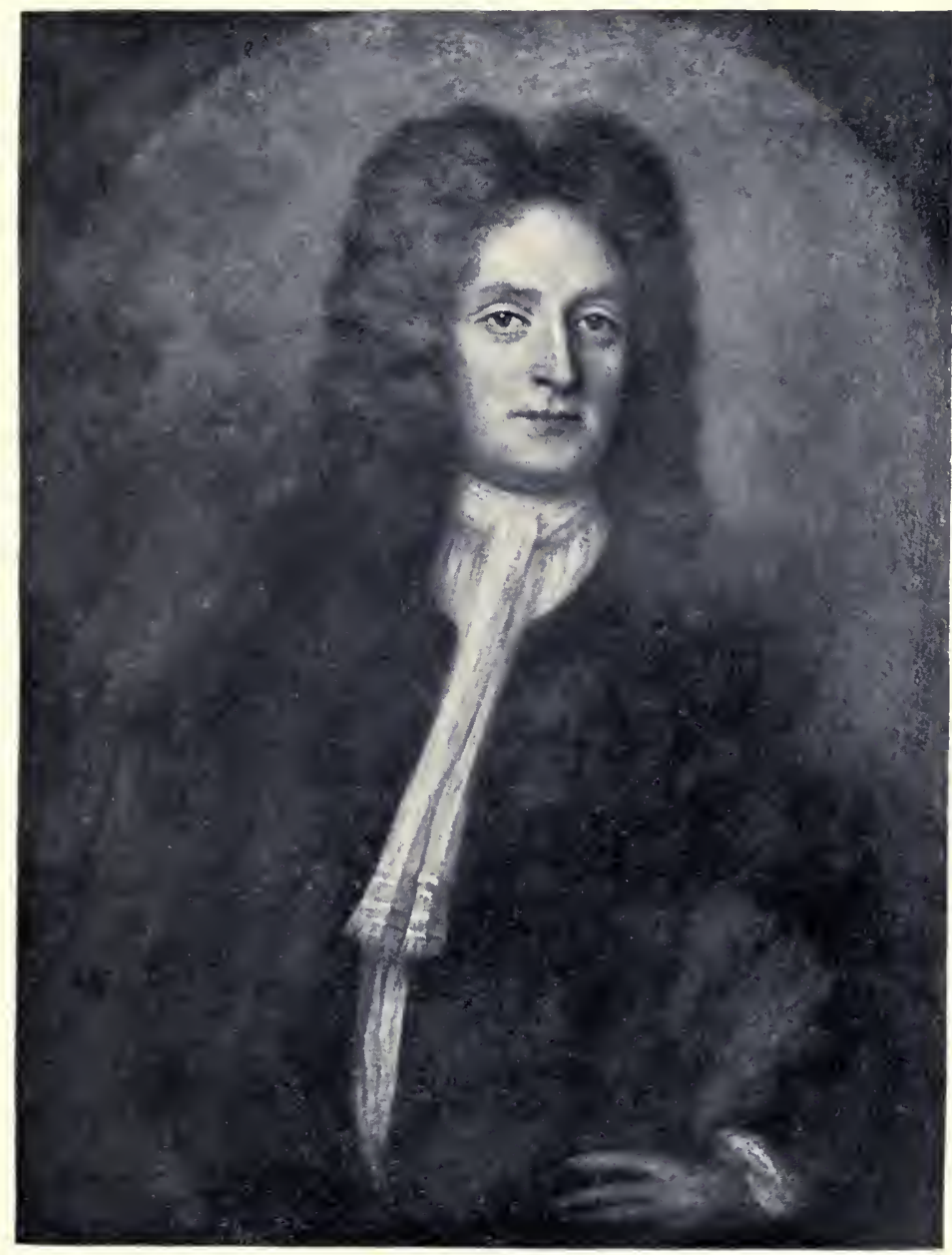

JOHN PATERSON OF PRESTON HALL,

From a Miniature on Copper by Madame Vorelse. 



\section{CHAPTER II.}

MY SCHOOLDAYS.

I was born at Charleton on 9th August, I 81 8. About the first thing I can remember was when George IV. came to Scotland in I822. My father took the Fife Yeomanry over to be reviewed on the sands at Portobello, and we had a flag on the top of the house at Charleton and another on the hill above Coates.

Our old nurse, Annie Gordon, came from Balgonie, Lord Leven's place near Markinch, which was afterwards burned down. She used to sing about the "Bountree Bank" and the "Warlock Craigie". She was a wizened old woman with a mutch, and used to make "sowens" (a kind of fermented oatmeal) in the nursery cupboard, and once a year she allowed herself a feed of raspberries and cream. She died at Charleton, and was buried at Newburn Church.

About this time Sir John Hope gave me a black pony called "Pinkie". I was put on him on a pad without stirrups, and I used to cling on by my heels.

One day the hounds met on the top of the hill at Charleton. I rode "Pinkie" and my sister Mary was on a donkey. Jimmy Honeyman went out to take care of us, riding my father's gig horse 
"Dragon," a black horse with a grey tail. Honeyman had been a private in the Fife Fencible Cavalry, and afterwards in the Fife Yeomanry, and was a groom at Charleton all the rest of his life. They found a fox in the Horse Shoe Wood and ran towards Balcarres, and the donkey ran away with Mary. Crane was huntsman. He had been huntsman in the Peninsular War with the Duke of Wellington. Mr. Rigg of Tarvit and Captain Wemyss were joint masters. On going to the covert all the field went through a gate except John Dalyell of Lingo, who jumped the sunk fence, which is now abolished.

We were in Edinburgh in the winter of 1825 , and lived at 35 York Place, next door to Colvin Smith the artist. He painted my sister Jean's picture. We had the whooping cough, and after that she was so changed that he could not finish it. While there I was sent to my first school, a day school kept by Mr. Knight in George Street, where there were about 120 dirty little beggars.

In 1826 my father, mother and one sister went to London, and posted all the way, taking me with them.

My uncle, William Adam, had a house in Great Russell Street, No. I04. He was a lawyer and accountant-general, and was also Commissioner for the Duke of Bedford, whose two sons, Henry and Cosmo, were committed to his care. I and my cousin, Willy Adam, were sent with them to school at Putney at Mr. Carmalt's. $\mathrm{He}$ was a big, stout 


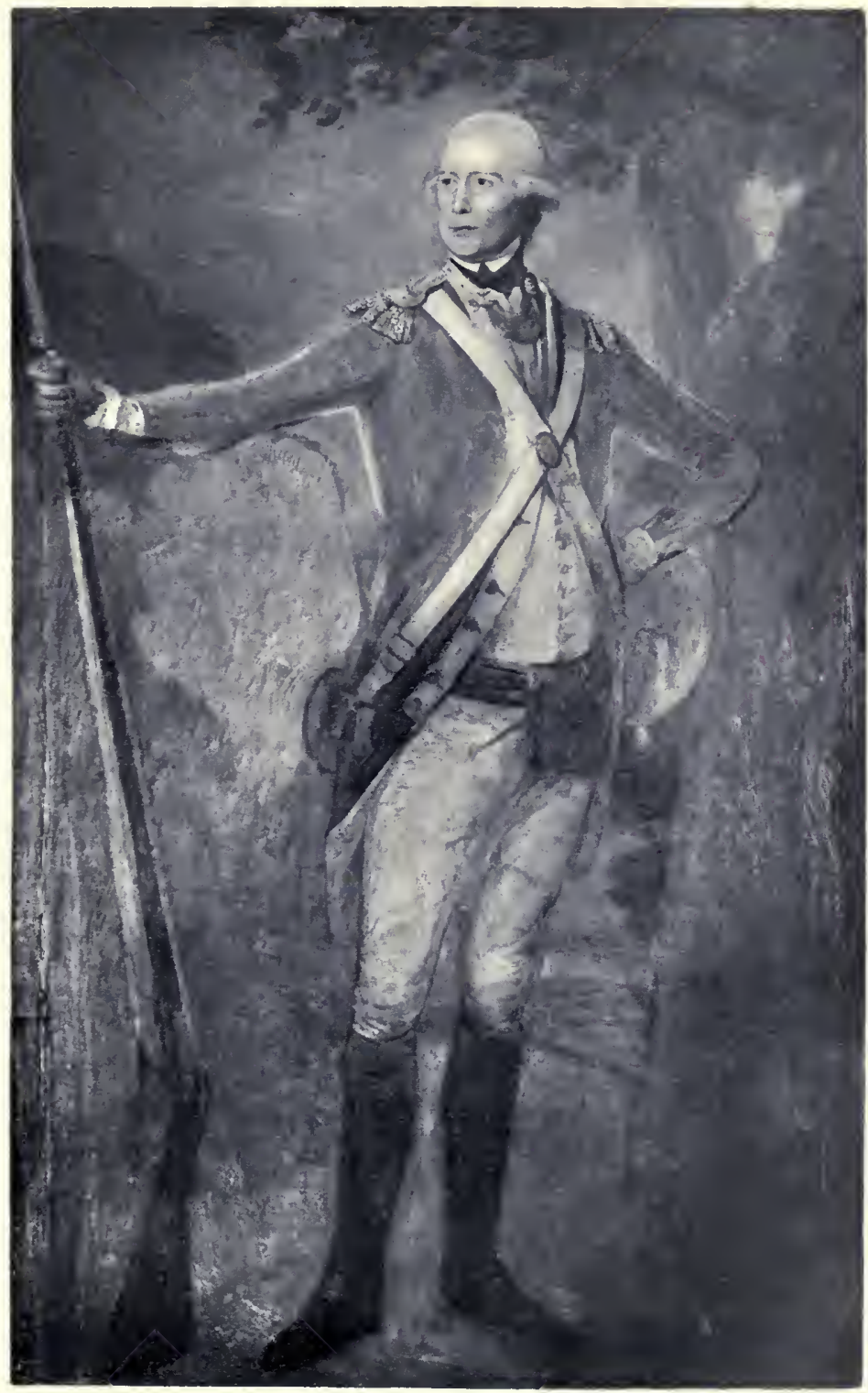

COLONEL JOHN ANSTRUTHER, 62ND REGIMENT (I8O3).

(MY GRANDFATHER.)

From a Painting by Martin at Charleton. 

man with a flat nose. There were about I 50 boys there.' There was a French master whom we called "Mousey". Willy Adam's mother was a Russian named Polteratsky, so of course he was called Polteratsky, and "Mousey" used to call him "Rattikit".

In those days little boys used to have what they called skeleton suits with their trousers buttoned over their jackets, but "Rattikit's" garment was more extraordinary still. It was light grey, with huge black buttons down the front, across the middle of his back, and half way down to his knees. This "Mousey" called Rattikit's "trap drawers".

My uncle had a house in Richmond Park at Sheen Gate (where Professor Owen afterwards lived). My great-aunt, Mrs. Loch, kept house with him there. He usually drove down from London on Saturdays and stayed till Monday, and often called for me and Willy Adam on the way and took us with him.

We were allowed to roam about the park as we liked. In those days the grand old trees were alive with birds of all kinds-hawks, woodpeckers, wrynecks and owls - and the ponds swarmed with herons, wild ducks, coots and water hens. My uncle gave me a copy of Bewicke's Birds, which I delighted to study, and got a deal of knowledge about them.

We were constantly in mischief, and the butler used to lock the doors and take away our clothes to prevent us getting up too early in the morning. We jumped out of the window, which was only some five or six feet from the ground, and ran about the garden with blankets wrapped round us. 
One Sunday afternoon we were bathing in the water trough at the cowhouse when a party of ladies and gentlemen from London appeared. We had no time to get our clothes, so we scrambled on to the top of the park wall and hid among the ivy.

In our first summer holidays we and our cousin, George Loch, went from London to Leith in the Tourist. She was one of the first steamers that sailed from these ports. She was quite small, and as it was very rough, I was very sick.

At Leith we were put into an Aberdeen steamer, and from it transferred into a small boat which landed us on the rocks at Elie, and we walked up to Charleton with George Loch and James Venables, my father's butler.

About this time percussion guns came to be in general use, and my father gave George Loch one. He himself always shot with a flint gun. During the holidays we went out hunting with Stewart's Harriers to hunt roedeer at Cruivie, near Kilmany. A young horse of Stewart's kicked me on the shin, and my father wrote an account of the accident to my mother.

“My Dearest Clem,- -

"A horse has kicked John on the leg. It is merely a bruise, but painful. Mrs. Gillespie and Tom Loch have bathed the leg in warm water and are going to put leeches on it and then a poultice. It is now only about an hour since it happened, and he desires me to say to you that he has now no pain. 


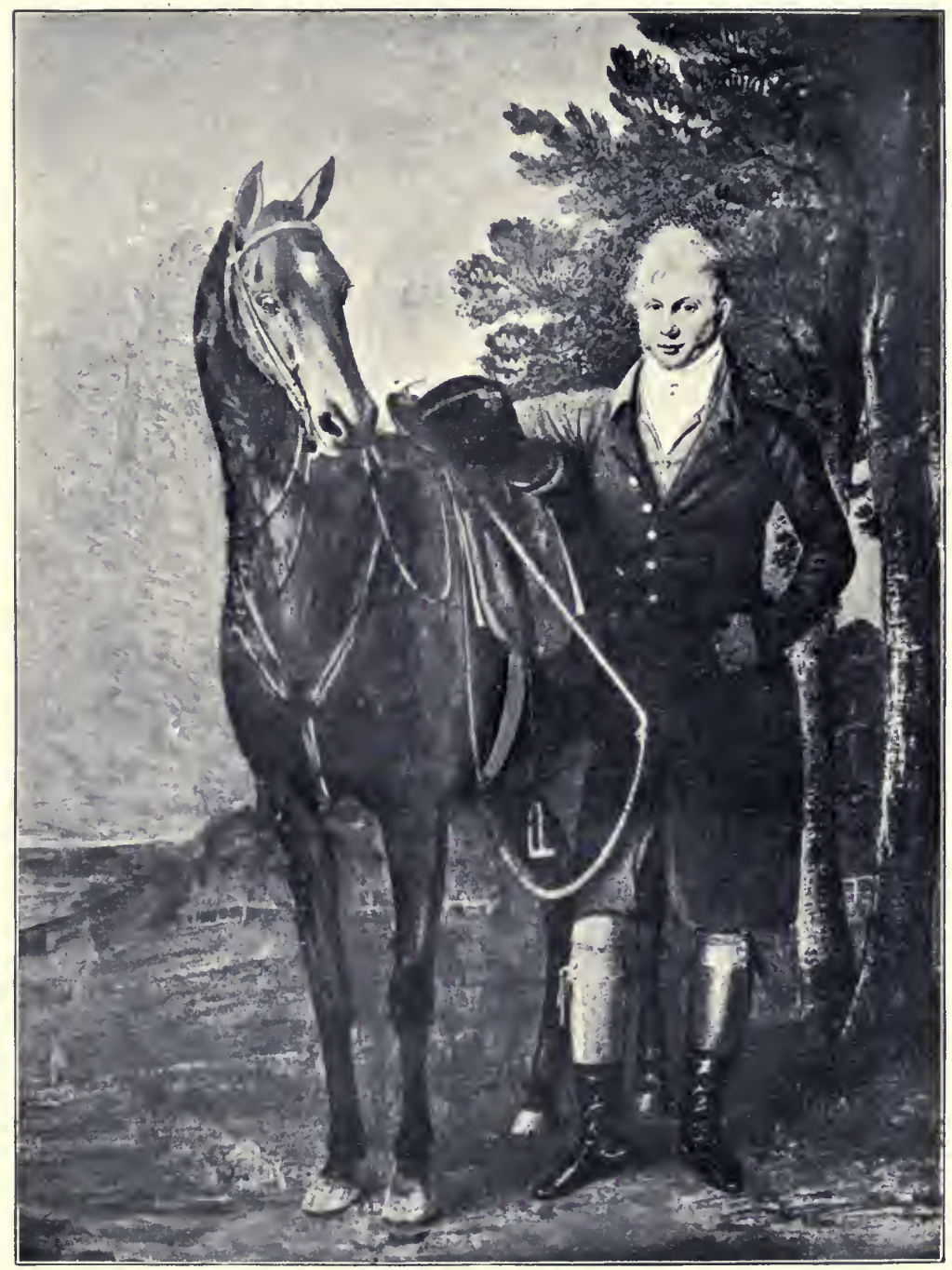

J. ANSTRUTHER THOMSON, LATE M.F.H., I807.

(MY FATHER.)

From a Water-colour Painting by Douglas. 

"Mrs. Gillespie and Tom do not think it even necessary to send for a doctor, but I doubt he will not be able to move by the steam-boat on Saturday, and I think it better that you should come here, as he will be better in the carriage than a gig tomorrow.

" $\mathrm{He}$ is now asleep, and by the time that you reach this I have no doubt but that he will be quite well.

" This house is full of ladies-Mrs. Bruce, Mrs. Maitland, Norah Loch and Susan Gillespie-so that you see John's hurt is not of consequence.

"Ever my dearest, "Yours J. A. T.

"Kilmany, Half-past Trelve, Wednesday.

"Since writing this I have found him laughing and eating grapes, so don't come, but send the carriage to-night to take him home to-morrow morning, as it is best not to trust to the gig in case of rain."

Next summer my uncle posted down from Richmond Park to Buxton, accompanied with "Granny Loch" and Mary, her grand-niece, and myself. I sat at the back of the carriage on the "dickey" with the footman, who wore top-boots, and was very fat and marked with smallpox. His name was George Baldwin.

My father, mother and sisters met us at Buxton, having driven all the way from Charleton with a unicorn team. Two of the horses were named "Sam- 
son" and "Goliath". The other one died at Harrogate, and they bought another for $£ 45$, which I used to ride afterwards at Leamington.

We met Mr. Graham of Airth and his son, Carolus, who used to go out fishing with me; Mr. Owen of Woodhouse and his daughters (the eldest became Mrs. Middleton Biddulph of Chirk, and the next one Mrs. Edward Williams); Mr. Billy Bagge and his sister, afterwards Mrs. Villebois; Sir Hope Grant, who was then a subaltern in the 9th Lancers, and his sister, Mrs. Speirs. They had balls in the hotel, and I danced with Miss Bagge! She was very pretty. While at Buxton Miss Owen allowed me to ride her horse-at least her father did. It was the first big horse that I had ever ridden.

We drove on from Buxton to Leamington, where my father consulted Dr. Jephson, who was famous at that time.

One day my cousin, Emily Adam, who lived with us, lost her watch in Wakerley Wood. I remembered having cut a hazel stick there, and next day we went back and found the watch at the very place where I had cut the stick.

We were all together there for the Christmas holidays. It was a tremendous hard frost, and Captain Hibbert of Bilton Grange," and Captain Pearson, afterwards the owner of "Achievement," etc., had a sledge, and gave us a drive on Christmas day. Mr. Fellowes of Shottisham, Norfolk, was then Master of the Warwickshire Hounds.

Willy Adam and I were at Putney three years, 
and on going home my uncle got his friend Phil Williams to examine us, and found that we knew nothing.

One ceremony at Putney took place every half. We were marched up to Carmalt's desk two and two. Two glasses of a horrid compound of bark were on the desk, and an usher stood on each side. We had to drink the dose, turn to the usher, and put out our tongues to show that we had swallowed it! This was charged in our account, "Wine, 5s."

We were removed from Putney. Willy Adam was sent to Laleham, near Staines, and I went to the Academy at Edinburgh. I was boarded at Mr. Dyer's, the English master. He lived in Raeburn Place. There were eight of us in the houseStewart McNaughton; Dick Moubray, afterwards Sir Richard Hussey; Bigge, afterwards parson at Stamfordham, in Northumberland; Dykes, the Hereditary Champion; Dundas, whose sister was Mrs. Farquharson of Invercauld ; Frank Johnstone, brother of Johnstone of Alva ; Lumsden, Sam Dyer and myself.

The night I arrived my tutor was ill in bed. At bedtime I made a "devil" of wet gunpowder on a slate, and set the bed curtains on fire. I managed to pull them down and put them out, but filled the house with smoke. However, it was forgiven, being a first fault.

My brother Willie and Tom Erskine, Cambo, were at school at Loretto, Musselburgh. A horsedealer, a great friend of my father's, Matthew Baird, 
lent me a pony on Saturday afternoons, and I used to ride down there to see them.

Mr. Dyer was too fine a gentleman for his position. He used to go out riding on a very goodlooking horse, called "Luck's All," which he hired from Tom King. While I was still there, he was arrested for debt and put into prison on the Calton Hill.

I walked over to Barnton one afternoon and saw Mr. Ramsay's hounds. Kit Scott, huntsman, Tom Rintoul and Jim Harrison, whips. One day we went to Craigleith Quarry. It was hard frost and a little snow. I was on the ice. One of the fellows threw a stone at me. I was stooping to pick it up off the ice, when plop I went in up to my chin. The ice kept breaking in front of me, but I kept wobbling on till I suppose I touched the bottom, when I jumped out and ran home. It was beastly cold, but I tumbled into bed and was none the worse of it.

Part of the time at the Academy, John Shairp (Principal of St. Andrews) was next me in school. He was as keen about hunting as I was. Our schoolbooks were full of pictures of horses.

The Christies of Durie were also at the Academy. Jim used to ride a fine horse of his father's called "Partner," and they had a pony called "Fidget". During the holidays they were at Charleton, or I was at Durie nearly every day, and we used to gallop all the way along the links and jump the ditches. No wire in those days. 
My first real hunt was in 1830 , when I was at the Academy in Edinburgh and at home for the Christmas holidays. We started on the "Balcarres" coach from 2 Princes Street, drove down to Newhaven (Granton pier was not then built), were put on board the steamer, and crossed to Pettycur. If it was low water we scrambled into a flory-boat, and were rowed to the pier. All the boatmen had high top-hats which they had rescued from the sea, having been blown off the heads of former passengers! We got on the "Balcarres" coach, which ran as far as Anstruther. They had three horses, and the coachman was John Beveridge.

My companions on the coach were Mr. James Melville of Hanwell, Mr. Willy Glass of Smiddy Green, and James Clark, farmer at Wormiston, the best and keenest of fox-hunting farmers at that date. He walked forty-two couple of foxhound puppies for the Fife Hunt, having kept a couple each season for forty-two years in succession.

The meet was at Balcaskie; Whyte-Melville and Captain $\mathrm{W}^{\top}$ emyss were joint masters. Walker was huntsman. He had been with Lord Kintore in the V.W.H., and also at Turriff in Aberdeenshire, and succeeded Crane, who died the previous season.

Tom Batters was first whip. Tom (Will) Smith was second whip. He came from Brocklesby, and was afterwards with Mr. Grant of Kilgraston, Lord Kelburne, Lord Shannon, at Castle Martyr in Ireland, and lastly at Brocklesby. He was also with Lord Southampton. 
I had a capital pony called "Tom Pipes," the picture of a little hunter. Mr. Melville had a beautiful black horse; Jimmy Rait had a black thorough-bred called "Cholera Morbus," and a cut whip "to bring the hind quarters over". Campbell of Saddell was also out. They ran all day in the woods at King's Muir, and while hounds were running in covert, Saddell sang "Arouse, boys, arouse".

About this time Sir Henry Bethune of Kilconquhar came to reside at home. $\mathrm{He}$ was Commander-in-Chief of the Persian army, and had the power of life and death in that country. He was a grand man, standing six feet five inches in height, very handsome, with the most courteous manners. He had a falconer and several falcons. It was a most interesting sport.

The falconers had an old setter dog which hunted till he found a covey of partridges. The falconer then threw off a hawk, which rose in circles till very high, then hovered above the dog. The dog looked up to see if the hawk was ready, and then ran in and roused the birds. Swoop went the hawk. If he missed, the birds generally went into a hedge, and the hawk soared again and hovered over the birds. The old dog then went off after them and got another point. If the hawk killed its bird the falconer went gently to it and picked it up. If not, he had to fetch the hawk with the lure, a dummy bird with a bit of pigeon on it. He called the hawk "Killy, Killy, Voiyooh," a sort of view-halloo, and hurled the lure 
in the air. The hawk stooped to it and began to eat the pigeon, and he then succeeded in picking it up.

Our keeper, George Etches, learned the trade. At that time there was a falcon's nest both at Kincraig Rocks and on the Isle of May. We got the young ones and kept them for two or three years. We lost a good many, for in a high wind they used to get so far away that they did not come back again.

Sir Henry was a man with grand and liberal ideas. He was asked to make a fox covert, and he planted thirty-five acres at Belliston, which was the best covert in Fife for many years. When he gave up hunting in 1847 I bought both his horses, and took them to the Atherstone country- "Percy" and "Guy Faux". Sir Henry went out to Persia again and died there.

In September, 1832, I went to Eton, and wrote to my mother as follows :-

“Mr. Coleridge's House,

"Eтon, Thursday, 2oth September, 1832.

"My Dear Mama,- -

"Uncle William brought me out here yesterday morning and then left me on his road to Scotland. There are a good number of fellows here, but I do not know how many. I have a room to myself, which I am in at present, but it smells horribly of mice. We breakfast by ourselves, but I breakfasted this morning with $\mathrm{Mr}$. Coleridge, because it was my first time. We dine all together in the dining-room with Mr. and Mrs. Coleridge. I am not placed yet, 
and I do not know when I shall, as to-morrow is a holiday. I daresay I shall like it well enough when I can make verses better. There are some very nice fellows here. Cosmo Russell has not come yet. There is a fellow named Scott coming into the same house from the Academy. Mr. Coleridge has a St. Bernard dog. He is such a fine chap, bigger than 'Neppy,' and just like the picture Eleanor drew of one.

"How is Nelly's sore throat and sore side. What have you done with 'Tom Pipes'; is he out at grass? "My dear Mama,

"Again your affectionate "John A. ThOmson.

"I got a new hat in London. I will write to Mr. Ferguson when I am placed. Write to me soon."

In Coleridge's house there were lots of good fellows-Stafford Northcote (Lord Iddesleigh), Lord John Manners (Duke of Rutland) and his brother George, Cosmo Russell, Harry Liddell (Lord Ravensworth), Fred Graham of Netherby, John Bastard, Mat Tiernay, two Champernounes, Scott Murray, Talbot Clifton and his brother Henry, Gisburne (called “Keggs"), Herries, George and Dick Curzon (Howe), Sandford-Graham, Farrar and Harvey Farquhar (I was his fag). They were all first-rate gentlemen.

My greatest friends were George Miles, "Kitty" Claggett and Eustace Arkwright. 
Wilkinson was captain of the school. George Lane Fox was sixth form or Upper Division. Godfrey Arkwright was captain of the boats, and Hare was captain of the second boat.

Frank Charteris (Lord Wemyss), Charles Scott and Andrew Blackburne went from the Edinburgh Academy at the same time Scott and I went to Coleridge's. I was placed in the Upper Remove fourth form.

Mr. Coleridge to my uncle, W. Adam :-

"ETon, 23rd September, 1832.

"My Dear Sir,-

"I send you these few lines, according to my promise, to inform you that Dr. Keate has placed Thomson in the Upper Remove of the fourth form, for which station he is well fitted by his general knowledge of Greek and Latin, but by no means so by his powers of composition in verse or prose. $\mathrm{He}$ is however, I trust, fully sensible of his own deficiency, and will do his utmost to make up what is now wanting from the anomalous system in which he has been trained. Can it be right or advisable to defer the practical application of any knowledge so long as it is usual to do at the Edinburgh Academy? Scott, who has just come to me from the sixth form, has been admirably trained in Latin and Greek, and is in all respects a very clever, well-informed and thoughtfulboy, and yet during the whole five years he has been at the Academy he has not put pen to paper once. I am no bigot to our own system; I VOL. I. 
think it can be improved in many points; but I am sure that Dr. Williams' cannot be right. It would be a very kind thing in any one, who was so privileged, to converse with him on the subject; but do not you on any account commit me. I am more than satisfied with the system so far as it goes; the fault, I find, is that it only goes so far.

"You will not, I trust, fail to visit Eton either on your way back or shortly after you return. In the meantime, believe me, my dear Sir,

"Yours very sincerely,

"Edward Coleridge."

Stafford Northcote was, I think, in the Lower Division of the fifth form. He afterwards became Chancellor of the Exchequer, and was created Lord Iddesleigh. His principal companion Gisborne, was very fond of natural history, had a capital collection of stuffed birds, and drew and painted birds most beautifully. I never saw him again after we left Eton, and I believe he died young.

Herries and Farrar were also great friends of Northcote's. Carew was usually called "Lobby," and afterwards became Lord Wexford. $\mathrm{He}$ was called "Lobby" because he always called the passage " the lobby".

Ascend the "lobby" now, O Muse !

The great Wexfordian room peruse!

Stafford Northcote had very light hair, and there was a Windsor boy who sang in the choir whose name was Jack Tabner, and whose hair was the 
same colour. Northcote was therefore christened "Tab".

Selwyn, who was afterwards Bishop of New Zealand, was then private tutor to Sir John Thorold, and they did not live in college.

Another fellow in Coleridge's house was Cornwallis Maude, afterwards Lord Hawarden. John Bastard and Mat Tiernay were in the same remove with me. We were up to Cookesley, and did six o'clock lesson with Luxmoore.

Northcote and Gisborne were among my greatest friends, and I remember them picking up long reeds and hurling them like javelins at each other, all the time quoting Homer and fancying themselves Grecian warriors. One of our great amusements in winter was toodling-hunting birds in the hedges and chasing them till they were blown, when we captured them. ${ }^{1}$

The following summer I was in the Victory, of which Marriot was captain. She was a horrible old tub ; it was like rowing in a barge. They gave us a new boat, and we immediately bumped the Thetis, the boat in front of us. Next year they promoted the Victory, and made her the second highest boat next to the ten-oar. I think Northcote was in the Victory that year, also Marks and Meux. John Quick was captain of the boats.

Tom Walsh was captain of the Thetis, and we pulled together in the lower sixes. $\mathrm{He}$ was stroke and I was five. We won it by half a length against

${ }^{1}$ My father died on Ioth April, 1833. I went home from Eton, and returned at the end of the Easter holidays. 
Clagget. Green was captain of the lower boats, but as he was in the eight of the school Clagget was put on as stroke for lower sixes.

After I became fifth form I used to mess with Northcote. I think he had then become captain of the house. He had nine fags and I had one, Harry Liddell, the present Lord Ravensworth.

I was very idle, and had no turn for doing verses. Northcote could compose them almost as quick as he could repeat them, and used to correct mine, and help me with them. The verses had to be sent in on Monday at midday school. Once we had a serious quarrel. One very hot morning I came in and found Tab at breakfast in his shirt sleeves, and his coat hanging on my chair. "Tab, take your coat off my chair." "I shan't," quoth he. "If you don't, I'll chuck it out of the window." "Shan't," he repeated. Away went the coat out of the window, and floated into the tutor's garden. Unfortunately it was Monday morning. Tab said, "You may finish your verses for yourself".

That week the verses were a very inferior lot, and my tutor was very much puzzled to know the reason why. However, we soon made it up, and were better friends than ever. ${ }^{1}$

My tutor was always afraid that I should influence Tab for evil, as I was very idle and fond of field sports. We used to have card parties, and sit on the floor and play at vingt-et-un for halfpence.

1 The verses were done by Tom Walsh, whom I never met again after leaving Eton till September, 1898. 
Once Northcote had to go away in the middle of a game, having lost about two shillings. He handed over to the boy who took his place a sheet of paper with these words, "Here is a schedule of my debts, and here is the sum of my possessions," and handed him a halfpenny.

We sometimes had singing parties too. I can remember a song of Tab's called "The One Horse Shay," beginning-

Mrs. Bubbs was fat and free,

And fair and forty-three,

And blooming as a peony in buxom May.

She long the toast had been

Of Farringdon-Within,

And took up the better half of the One Horse Shay.

In July, I833, Mr. Coleridge wrote again to my uncle :-

"My DeAr Sir,-

"As your nephew is to see you on his way through London I shall send you a few lines to assure you that he is going on very well in all respects, except his school exercises. He is extremely good tempered, regular and attentive enough to his lessons; but he does not take as much trouble as he ought with his prose or verse composition. He might do more without any great act of self-denial, and I wish you to make a point with him of his raising himself by his industry. Could we effect this it would be of value not only for itself, but also as a probable means of keeping him out of the only evil into which I have any fear of his falling-namely, a reckless, coarse manner, and an excessive abandonment to bodily, rather than 
mental pursuits. I do not wish to prevent, but to moderate his pursuit of such recreations, and to teach him that a union of the two adds sweetness to either.

"You will be glad to receive from me a good account of Lord Cosmo Russell. He is doing well, and might, if he were not a Lord, do excellently. As it is, I will screw him up to the utmost point I can. The King will certainly ask for an additional week's holidays to-morrow, in which case your nephew's day of return to Eton will be Saturday, I 5 th September, unless, indeed, you would wish him to avail himself of another week, a privilege usually granted to Scotch boys on account of the distance.

"I am very sorry you have never paid me your promised visit; but I daresay you can show cause.

"Ever yours, my dear Sir,

"Very faithfully;

"Edward Coleridge.

"ETon, 28th July, 1833."

I left Eton at Christmas, I 834. On the last day I went out hunting with De Burgh's staghounds, on a hack of Bob Davies. Eustace Arkwright went with me. He wore a red coat; I wore a green one. My boots were made (by an order on old Ingleton) with a seam down the back instead of the old Wellington pattern, and I gave him fourteen shillings extra to make a pair of tops. I left them (the tops) at my uncle's house in I 3 Berkeley Square when I went abroad. When I returned the house was sold, and I never saw them again. 
CHAPTER III.

GERMANY.

After leaving Eton I went abroad with Captain Lethbridge, Royal Artillery, as tutor. He was rather a stuck-up chap, but we got on pretty well. We started on top of a coach from Gloucester Coffeehouse in January, I835, sailed over to Ostend, ran aground, and had to wait till the tide rose. Luckily it was very calm. At last we got to Ostend, and went on to Saxe-Weimar.

" 9 th January, 1835.

“My Dear Mother,-

"We have arrived here at last in the middle of yesterday morning at two o'clock. I never felt it so cold in my life, and we got cold rooms and were obliged to get beds made for us; but now we have got into our own abode. Sir John Hope had written to General Slybach, or Swybach, that we were coming, so he had got lodgings ready for us. He is very good-natured to us and very useful. We had a recommendation to Baron Someone from Baron Ompteda, and we got an invitation last night to a ball there; but it is not proper to go anywhere and meet the Grand Duc till you have been at court, so we asked the General what we should do, and he 
told us to go, and that if the Duc made any objection the Baron must bear the blame. So we went and were introduced to the Duc. He is a great, fat man, but goes bustling about and talks to every one. We go to court next Thursday, and we who have not got uniforms are obliged to go in a dress like a Quaker's-all black with a sword and cocked hat. There are immense lots of English here, viz., Preston, McFarlane, Miller, Horrocks, Tomline (who were at Eton); two Hopes and Mr. Sproat, their tutor ; another Miller and Mr. Halley, their (Miller's) tutor, who I know was an acquaintance of Miss Applebee's.

"I think I wrote to you last from Brussels the day I could not go to Waterloo. We passed over the field the next day in the diligence. The conductor had been a French soldier and was wounded there, so he told us all about it. We have been at Cologne, or Koeln as the Germans call it, and came along the banks of the Rhine. They are very fine and must be beautiful when green in summer, but not anything wonderful, I think. There are immense rocky hills covered with firs and copse on each side and vineyards between them and the river. It has been a hard frost here and there has been some snow, but to-day I am sorry to say it is a thaw. Sir James and Lady Hamilton are here. You may recollect them at Leamington. We have got a young German clod to clean our shoes and brush cloes and be generally useful. He can't sprechen anything but Deutch, so we hold telegraphic communications, and 
he twigs most wonderfully quick. You must direct to the Poste Reste, Weimar, Saxe-Weimar. Our landlady's name is Voight, and she only speaks German, but she has a daughter who interprets. I have filled up my sheet, so I shall stop.

"Your affec.

"J. A. Thomson.

"Write to me directly and tell me all the news. Tell Nelly that the Captain waltzes so well that the ladies kept him well employed last night in a dance (as they do when they pick up any one for a partner), and he was so tired all the time, for we had not been in bed for two nights, except yesterday morning."

Sir John Hope of Pinkie had given us letters to General Seebach, the Oberjägermeister. We went to call on him, and found a tall old gentleman with his grey hair cut very close, dressed in a shooting jacket, standing at a desk reading an English slang dictionary. He was a grand old man and very kind to us. Willie Hope (afterwards General commanding in Edinburgh), Norman M'Leod (tutor to Tom Preston), Rocheid (father of Mrs. Briggs of Strathairley), Horrocks, etc., were there.

The Grand Duke was very kind to all the boys. The Grand Duchess was a Russian, and a charming lady. We were all dressed in court dress--black straight-cut coats, cocked hats, knee-breeches and black silk stockings, and we all stood in a row like young rooks.

The Grand Duke used to walk round and say a 
few words to each of us. "Avez-vous bonnes nouvelles de vos parents?" "Have you good news of your parents?" The Grand Duchess spoke perfect English. We were sometimes invited to dinner. Among the guests was Sir James Ramsay of Bamff, who had a curious trick of saying, "Eh, quoi, what?" On being invited by the Duke to take a glass of wine (which was the fashion in those days), he replied, "Eh, quoi, what?"

Our German master, Dr. Weissenborne, was a most eccentric man-a tall, pale man, with huge spectacles, and a very strong smell of tobacco. $\mathrm{He}$ usually carried a chameleon inside the breast of his shirt, and he had a little Dachshund called Waldina. His knowledge of the English language was not very correct. On hearing of runaway matches to Gretna Green, where the parties were married by the blacksmith, he said, "Is it necessary to be a blacksmith to perform marriages in Scotland?"

Norman M'Leod was much in love with a charming girl called Melanie Speigel. Many years afterwards he was at Elie, and came to dine at Charleton. I had never met him since our Weimar days. I took his wife in to dinner. He said, "Tell her all about Weimar-she knows about Melanie Speigel."

The Duke used to ask us to the Jagd (to shoot hares). They surrounded the district for two or three miles with several hundred men, a gun and a beater being placed alternately. We then marched slowly in towards the centre. At the end of the Jagd it was like a regiment firing volleys. The Duke was 
attended by some mounted hussars, who occasionally acted as retrievers. I have seen one cutting three and four at a wounded hare. We always had a grand luncheon in the middle of the day.

\section{"Weimar, Widnesday, 4th February, 1835.}

"My Dear Mother,-

"As Miller, ${ }^{1}$ the bearer of this, starts tomorrow morning from this place to England, I think it is a good opportunity to write to you, as he has volunteered to take it. He has been here for some time, and has got his commission in the I 2 th Lancers, so he is now returning home.

"I received your and Willie's letter the other day. Willie's letter is very amusing. I hope the next will be more extensive. You need not be the least afraid that there are not enough Germans to talk German to, as there is a whole regiment of soldiers, and very few of them can speak anything else. General Seebach told me that he heard from Pinkie that some of you had been at a masquerade. $\mathrm{He}$ is a jolly old fellow, and has a son who talks English very well. Monday was the Duke's birthday, so there was a grand dinner, and last night a ball. We could not move last night without treading on a prince's or a princess's toes. A princess sent a page to Captain Lethbridge commanding him to dance with her, which he did. They are the oddest looking people ever you saw. When we first saw

\footnotetext{
${ }^{1}$ Sir William Millar of Glenlee.
} 
them Horrocks exclaimed, 'How on earth did they ever get so many screres together?' They have a splendid room at the palace built of marble; the walls are a yellowish sort of marble, and there is a gallery supported by white columns, and all sculptured at the top. It is quite splendid when lighted. German is rather a stiff language. Captain Lethbridge cannot get out any of the gutturals and is quite in despair; but I am not, for I can speak to the servant, who says 'water' in English and 'queskesay' in a sort of German gibberish. We are going to a soiree to-night at Tomline's. I received a letter from Aunt Louisa at the same time as yours. We get English papers here, and I see that Admiral Fleming lost his election and something about a fire at Edinburgh. Let me hear about it. I have nothing more to say, but I thought it a good opportunity to write, so I shall stop as I have no more time.

"So good-bye,

"Your affec.

"John A. Thomson.

"I have directed this to Charleton, as you may have returned there before Miller has arrived, and I have enclosed it."

In the spring we went to Berlin, and saw a good many reviews, and became very intimate with a number of German officers. One day, when we had stopped for luncheon in a wood, we found a chap hanging on a tree. He was quite dry, like a mummy. 
We went from Berlin to Dresden and lived in the Pernieische Gasse. Count Fredro was on the first floor and I and Lethbridge above him. Countess Fredro was a Russian-a great tall gaunt woman, who spoke English very well. A Russian girl lived with her called Katerina Simionofska. We had a dancing master who used to dance at the opera, and taught us gymnastics and waltzing, and we used to practise with Katerina.

The chaps at Dresden were Lord Alex. Russell, Bob Balfour of Balbirnie, Lord Stair, Lord Blantyre, Rashleigh, Pat Baker, John Udny and Gordon Cumming.

During the summer Lethbridge and I went to the Saxon Schweiz. We lived at a pub. and ate "blauen Forellen". We then went on to Teplitz-a most wonderful country for partridges. There was another Englishman there whose name I forget, and we went to interview the Oberjägermeister to ask permission to shoot. We found him sitting with his feet in a tub of hot water. He gave us leave, so we hired two guns and "Patronen," and joined the Jagd next day. There were about a dozen officers in uniform and some pointer dogs. All the crops were in narrow strips and the partridges got up by scores.

We returned to Dresden and remained there the next winter. We were joined by Henry Gordon, brother of Khartoum Gordon. His father was an artillery officer, and a friend of Lethbridge's, and Henry Gordon remained with us all winter. After leaving Dresden I did not see him again for forty 
years. One day I was at Woolwich at the Artillery Barracks. I wanted to get a patrol jacket as a pattern for the Fife Light Horse. I asked Major Talbot, with whom I was staying, if he could help me. He said, "Come along to the Arsenal," and being shown into the Governor's room I found my old friend Henry Gordon. We rushed into each other's arms. This was not very long before his brother's death, and he was shortly afterwards made a baronet.

One morning we saw an execution. Three men had their heads cut off with a sword. A wooden shed was erected in the middle of a great plain, and many thousands of people were present. It took place soon after daylight on a winter morning. The victim was placed in a chair with his arms tied. The Scharfrichter stood on his left rear, with a broad square-pointed sword. He did not raise his hand, but brought it from right to left with a sweeping cut, and the man's head just rolled away down an inclined wooden trough, and the body was slipped into a coffin at the bottom. The third man was very much excited, and I distinctly heard him say, "Ich bin unschuldig vor die Augen von Himmel". He would not sit still, and one of the assistants held him by the hair while the executioner cut his head off. This was about the last time an execution of the kind ever took place. They were all three chimney-sweeps, and had murdered an old woman to get possession of her money, but only succeeded in finding a few groschen. 
In August, 1835, while I was at Dresden, I was gazetted to the 17 th Lancers. Lord Lucan commanded the regiment at that time. My guardians considered I was too young, and requested the Commander-in-Chief, Lord Hill, to cancel the commission. A few months afterwards Lord Rosslyn, then Colonel of the 9th Lancers, offered me a commission, which was accepted with the understanding I was to have six months leave.

It was a tremendous hard winter, the thermometer $30^{\circ}$ below zero. People had their ears frost-bitten while crossing over the bridge.

We made great friends with the Cherini family. He was General in the Saxon army. He had a charming daughter, and his son had got a commission in the Austrian army. I was just appointed to the Fife Yeomanry, Sir Ralph Anstruther's troop, and he sent me a uniform. The.jacket was almost the same as the gth Lancers.

One evening we put on our uniforms, and Cherini said mine was prächtig. His was white coat, kneebreeches and gaiters.

Towards the end of the winter Gordon went home and Lethbridge and I went to Prague. The snow was tremendously deep, and the roads so bad that ropes were tied to the top of the diligence and men hung on to them at the bad places.

We went on to Vienna and remained there till the weather got better. We then bought a carriage and posted all the way to Nancy.' Passing Nancy we went to the salt mines. 
"Horse Guards, 2nd February, 1836.

“SIR,- -

"I am commanded by General Lord Hill, to acquaint you, that on your lodging the sum of $£ 840$ in the hands of Messrs. Cox \& Co., Army Agents, His Lordship will submit your name to His Majesty for the purchase of a Cornetcy in the gth Light Dragoons.

"I have the honour to be,

"Sir,

"Your humble Servant,

"Fitzroy Somerset.

"To John Anstruther Thomson."

I was gazetted on the 12 th of March, 1836 , and passed that summer at Nancy in a pension at Madame Lerboullet's. My window looked out on the barrack yard of the cuirassiers. There were two families I used to visit-Kortwrights and Major Fitzmaurice (his wife was the sister of the parson at Clyro). Harry Villebois came there for a bit. At that time a M. Gastaldi was living near, and invited us all to a feast (where we got very merry) and a musical performance (where each guest took the part of a different instrument). Harry Villebois and I had a round or two to demonstrate the art of self-defence. We all slept on the premises, one of the Kortwrights and I under the billiard table.

While at Nancy I wrote the following letter to my mother :- 
"NANcy, Tuesday, Ioth May, 1836.

"My Dear Mother, -

"I received your letter this morning and one from Mary yesterday, and as I shall tell you all my news in this, if you will pass it on to her it will do as an answer to both.

"You did not perhaps know before writing, but I suppose you will before receiving this, that I am going to stay here two months longer. I am both glad and sorry. In another month I shall talk French like a house-a-fire. Next Saturday we go to Metz with Mr. Chamberlayne in our carriage (if we can't sell it); if we do sell it, in the 'dilly,' I suppose. Capt. L. will not come back here, but Mr. Chamberlayne and I will. I am going into a pension, but have not yet settled where. About a week ago there was a grand wedding here. The bride's gown cost $£ 400$, and was made of point lace. Two days after there was a ball to which we went, but there was such a crowd it was impossible to move, much less dance. I suppose by this time you have seen the 9th, as Mary informs me that they marched into Edinr. on the Ist. You may send me a description of them. The new Cornet Spicer was at Eton with me, I think, and is a very nice fellow if the same. By-the-bye, I received Max F.'s letter two or three days ago. I wonder why on earth he sent it to Britain-I will row him for it. I am just going to write to Willie. Do you really think of making him an engineer or artilleryman? I think it would VOL. $I$. 
be a capital plan. Mr. Chamberlayne paints very beautifully and gives me a lesson whenever I choose, so I have three brushes and eight colours-oil-and dab away, and I think I shall succeed when I know a little more about the palette. When the weather turns finer we are going out to sketch. By-the-bye, about fourteen days ago we went to the salt mines at Deuze. We got into a tub and down we went 450 feet, and found ourselves in a vault about twenty-four feet broad and high, and perhaps a mile long. There are a number of streets at right angles supported by pillars. The salt is as hard as rock, and is all blasted and cut with pick-axes. They say that the echo of a blast is very beautiful. Capt. L. and a Count Gastaldi who was with us sang some duets, which echoed beautifully. I fancy John Dalyell must be rather disappointed with his English hunting-he has got such a bad country. An old gentleman here lent me (your horror) the Sport. Mag., and I saw all about it, also that the $9^{\text {th }}$ are all famous riders. I suppose I must have some horses when I join, but the Colonel will tell you all about that. I was hard at work all yesterday afternoon with a pick-axe and spade cultivating Major Fitz-Maurice's kail-yard, and am going at it again to-day! He has got such a nice boy, three and a half years old-such a manly little fellow, and if I ever become a colonel he is to be in my regiment. I suppose Hamilton has left the castle, but you did not tell me where he is gone to. At Vienna I got some music and put it into my shako, and that into my porțmanteau, and Capt. 
L. did the same. They have been ten weeks on the road now and are not yet arrived.

"I have not got no more to tell you. By-thebye, thinking of negations or negatives, in one of the travellers' books somewhere or other I read the following: 'A Cockney having lost his hat at a party exclaimed, "Hasn't nobody not never seen ne'er a 'at nowhere"'. However, having told you all my news, give my love to Clem, and tell her to get well. How glad I shall be to have a chat at home, and I am,

"Your affec.

$$
\text { "J. A. Thomson." }
$$

I left Nancy on the top of a diligence, on a very hot day, with my poodle "Lorrine". The dust was perfectly awful, and the heat stifling. Two French soldiers were my compagnons de voyage, and I produced my commission, which caused them to remark I was bien heureux to be a sous-lieutenant at such an early age. I was then 6 feet 2 inches in height, according to my passport: "Cheveux blonds, yeux bleux, nez moyen, menton rond, . . . taché de rousseaux". I went down the Rhine to Rotterdam, and there embarked for London. 


\section{CHAPTER IV.}

9TH LANCERS.

ON the 3 oth of July I went to report myself at Piershill. Lord Loughborough was then the LieutenantColonel. I borrowed a horse from Matthew Baird in Dublin Street, and rode down to barracks. I wore a long green bombazine coat (made in Germany), white duck regimental trousers, a high tophat with a very narrow brim. Being rather ashamed of it I rammed it under my chair, but Tom Whalley immediately discovered it, and said, "Twig his hat!" Arthur Williams, who had known my sisters at Eaton Mascott, took me under his protection, and gave me good advice, and made me buy a green account-book. I was appointed to "C" Troop-Captain, Percy Williams; Tom Whalley was the Lieutenant.

"Piershill Barracks,

"Monday, August, 1836 .

"My Dear Mother,-

"I will give you an account of what I have done since I left you. On arriving in Edinburgh I got a horse from Baird and trotted to the barracks with my credentials, but as neither Loughborough nor Colonel Campbell were there I went to the Adjutant, a jolly old Irishman named Cooke, and he 
showed me the mess-room, etc., and introduced me to Arthur Williams, who told me what I should do. I then went back to Edinburgh and dined at the Lochs. I like Eliza very much, but Mr. Walker had just gone away, so I did not see him. I slept at Charlotte Square, and yesterday had my things sent down here and came myself. In the evening I went out riding with Spicer and Johnston, dined at mess at half-past seven, and went to bed. Colonel Campbell is gone to inspect a troop of yeomanry somewhere, and they expect Loughborough to-day, but it is doubtful if he will come or not. I have got into Meicklam's room. He is on leave, and has left his bed and furniture; but as there were and are sundry bugs in it, the sooner I get my own the better. I have got a soldier-servant named Jenkinson, and his wife cleans my room and washes everything for twenty-five shillings a month. We all breakfast in the mess-room when and how we choose, and all the teapots, etc., belong to the mess, so I don't want any. Send me some shirts as soon as possible, though only two or three are finished. I am in Percy Williams' troop. He is very goodnatured and amusing, though rather a rattler. Whalley (pronounced Wayley) is the Lieutenant. $\mathrm{He}$ is a little gentleman-like, rather swell fellow, and has set me all a-going most swimmingly. I like Spicer, Spottiswoode, Whalley and Johnston best. My horses are in great strength and beauty-health, I mean. I rode the mare yesterday, and she is as wild as a great cat. She is very much approved of, and 
is the largest in the regiment, about sixteen and a half hands high. Spicer is very unlucky. $\mathrm{He}$ bought two horses from London; one turned out a roarer from a cold it caught in the steamer, the other is coughing. To-morrow is a field day. Where do the livery buttons come from ?-for they all recommend putting Mr. Smailum into livery.

"Don't forget my shirts. By-the-bye, what were the accounts of Ann Loch which you received on Saturday? Eliza wants to know. Send my two cane hunting whips, my gun and everything else. Mind the shirts and sheets and blankets, if you have them, and I am,

"Your affec.

" J. A. Thomson.

"Lord Loughborough is going to take a levy down to Doncaster races; perhaps he will take me. Love to every one. It is beastly weather. When it is clear I can see the Horse Shoe Plantation."

\section{TH LANCERS (1836).}

Colonel Campbell of Craigie was the Major.

Captain Fullarton, a quiet old gentleman, died in India during the Mutiny.

Percy Williams, my Captain, a capital officer, a very fine horseman and race-rider ; afterwards hunted the Rufford Hounds for nineteen seasons.

Arthur Williams, called "Jelly," a dear good chap, took charge of the mess, and was very kind to the Cornets. 
Hope Grant, afterwards a most distinguished General, commanded the cavalry during the Indian Mutiny.

Hankey, called "The Squire" (married), lived at Rosebank, and drove in every day in a dog-cart.

Archy Little, called "The Corporal," the best of good fellows, afterwards commanded the regiment in the Indian Mutiny.

Clark, afterwards Sir James, of Penicuik, called "Massa," devoted to playing the fiddle. He had a huge charger called "Paganini". One day some one stuck a pin in his crupper; the result was awful.

Tom Porter, a dear good chap, capital sportsman, afterwards "Father of the Berks Hunt.".

Andrew Spottiswoode, a very nice chap, but queer temper. He was next in the entail of Charleton, a capital horseman, afterwards commanded ist Dragoons, and married old Campbell's daughter. He was my second cousin.

John Spicer had been at Eton with me, a capital fellow. His father lived at Esher Place, now Sandown Racecourse, and drove a team of grey horses in a yellow coach. Esher Place was sold, and John Spicer bought Spye Park, Chippenham. During the winter of 1836 Spicer stayed with me at Charleton, and he had a mount out hunting on "Paddy," my mother's carriage-horse. The meet was at Kingsmuir. Whyte-Melville was master; Walker, huntsman; Glover, first whip; W. Hawtin, second whip. We got home very late. "Paddy" not going so free 
as usual, Spicer got off to examine, and said his feet were " all flat". He had lost both fore-shoes!

Frank Willoughby, brother of Lord Middleton, a first-rate good fellow, good horseman and keen sportsman. He died in India.

Fred. Isacke, capital fellow, very good-looking, had a beautiful voice and sang nicely. His brother married Miss Wedderburn, Birkhill. He married Miss Mary Fortescue in 1846 , when I was quartered in Dublin, and I was his best man. Her father appeared in nankeen trousers and a blue coat with long tails and steel buttons. When the clergyman in the service asked, "Who giveth this woman," etc., he shouted out, "I do," and made the roof of the chapel rattle.

Our uniform was: Red jacket (double-breasted), blue facings, gold embroidered collar, a short bobtail; wore belts outside the jacket, a gold sash for balls, blue over-alls, red stripe, white trousers in summer, Wellington boots ; no mess waistcoats, dined in stable jackets buttoned up ; lancer caps, square top, very heavy, and blackcock's tail plume. Armed with lance, sword (curved pattern) and pistols, white sheepskin and blue shabraques.

The regiment was very well mounted-great big well-bred horses with bang tails, which had just come into fashion. Our men were very good-looking. Lord Loughborough would not take any man under 5 ft. 9 in.

At that time privates when off duty wore their swords, and in the event of street rows were some- 
times rather handy with them. The infantry also wore their bayonets, and stabbing was not uncommon. The men were very smart and good riders, and the regiment was celebrated for trotting in line.

The horses were not so well broke as they are now, and were very vicious in the stable: no stranger dare go up to them. It was not an uncommon thing for a troop horse to run away after a charge, and in turning out for mounted orderly, there was often a turn of buck-jumping before the horse could be got up to the guard parade.

The men were a wildish lot, and very often late for watch-setting, but as long as the duty was well done not much notice was taken. When the orderly sergeant reported men absent at watch-setting, "Give them half an hour," was the usual answer.

I was one month under eighteen years when I joined, 6 ft. $2 \frac{1}{2}$ in. high, and weighed 12 st. $8 \mathrm{lb}$. Before I joined I got two horses from John Elmore in London. General Wemyss, who then lived at the Stud House at Hampton Court, and had charge of the Royal Farm at Windsor, was good enough to go with me. I got a very good-looking bay mare, about 16.2 hands, and a coarse bay horse. They cost me $£ 70$ and $£ 50$ respectively. At that time many of the horses suffered from diabetes caused by kilndried oats, and my two suffered severely. I bought a very good brown horse, "John," from George Inglis in Edinburgh for $£ 145$, and had him for eleven seasons. I rode him cub-hunting in the Atherstone country in 1847 . 
At that time Lord Loughborough had a race-horse called "Shamrock". He was very queer tempered, and difficult to ride. Percy Williams was one of the best gentleman-riders of the day, and won many races on him. He ran at Cupar Races, when the Caledonian Hunt took place there in 1839 , for the last time.

Percy Williams was a capital officer, but he was always on leave when he could get away. That year he went to shoot at Glendye, Sir James Carnegy's, and took old Martin, Lord Loughborough's keeper, with him.

Tom Whalley was a charming man, very clever, full of fun and wit, rather sarcastic, and a most fastidious gentleman. His brother was a clergyman near Northampton. He remained in the regiment about three years after I joined, and when he retired I got his troop.

I bought a capital old horse from Clark called "Charlie," a grand jumper. One day I was riding him with the Linlithgow and Stirlingshire Hounds, galloping along the side of the canal at Drumshoreland Wood. A heap of stones was lying in the way, and he turned round and jumped into the canal with me. We got to the other side. I got my arm on the coping-stone and bundled out, turned the reins over his head, and he jumped clean out. I was wet up to my neck.

I was set to drill and do the "goose step" with John Spicer, and got on so fast with it that the sergeants thought I had been in the German service. The riding-school was no trouble to me. 
Our principal drill-sergeant was Sergeant Baird, a little ugly man, with his chin-strap behind his jaw, but very smart and a capital soldier. In teaching sword exercise he desired us to "thrust the pint (point) well home and turrn the sworrd to render the wound incurable". Cooke was the Adjutant, an Irishman who had risen from the ranks and was a fine specimen of an old soldier. He had been promoted over the head of the Regimental SergeantMajor, named Payne, father of Charles Payne, the Pytchley huntsman. Payne broke his sword in two and placed it on the fire saying his soldiering days were over. This was told me by Charles Payne at Pytchley kennels fifty years after. The Sergeant-Major of the "C" Troop, Doyle, had a very good-looking grey horse which I sometimes rode. One day, when orderly officer, the horse being very fresh clattered about on the stones, and unfortunately Lord Loughborough saw it from the office window and called Captain Williams' attention to it. He selected the four biggest brutes in the troop for my benefit.

A few months afterwards the Earl of Rosslyn, full Colonel of the regiment, came to inspect us. The field-day took place on Portobello sands. I was his orderly officer, and he rode Sergeant-Major Doyle's grey horse. It had a very bad mouth, and behaved no better with him than it did with me, and his lancer cap got on to the back of his head, and was rather uncomfortable. On returning to barracks he remarked that the horse had a bad mouth. Lord 
Loughborough then rode it himself, and said he was ashamed that the General should have been mounted on such an ill-mannered quad!!

One day when I was orderly officer I turned out and inspected the guard without having my sword on. In the afternoon it was raining hard when the guard mounted, and I was proceeding to inspect it with a mackintosh on, when the office window was hurled up, and a stern voice said: "Don't go and get into another scrape; I saw you inspect the guard without your sword," and turning to Colonel Campbell said : "Is that the way you allow the duty to be done?"

Hope Grant was junior Captain when I joined. He was the truest and kindest of friends, and a most agreeable and cheery companion. He was a dear friend of mine all his life. A first-rate horseman, with good hands and undeniable nerve-no matter what country or what horse-he was sure to be in the front rank. His horses, although always well bred, were not always quite first class. I remember his buying at Laing's Bazaar in the Lothian Road, Edinburgh (now the site of the Caledonian Railway Station), a grey half-bred Arab mare, which had been bred at Dalkeith, for $£ 7$. A few days afterwards he appeared on it out hunting, and went as well as other people. His hack was a wall-eyed Highland pony which had cost $£ 5$, the value of the whole establishment being thus $\ell_{\mathrm{I}} 2$. He was also a keen golfer, and a most enthusiastic and accomplished musician. In the evening he would play for hours on the violoncello. At that time Signor 
Emiliani, a celebrated violin player, was in Edinburgh, and he delighted to get him to accompany him.

He rode in the military steeplechase at Northampton in I84I previous to going to China with Lord Saltoun. I think I can see him now, after the race, with a red worsted comforter round his neck, a hunting cap, and his knuckles covered with blood from contact with the bullfinches, and saying "It was capital fun ".

On his return from China a dinner was given to him by the members of the Club at St. Andrews. The toast of the family at Kilgraston was entrusted to me, and I said: "We have all met here to do honour to our noble guest, who has served his country well and done his duty ; but we also are assembled here as a party of gentlemen to welcome our old friend and playfellow, and it is very gratifying to find that this successful General, who has led victorious armies, is still our old friend, the same frank Hope Grant, the same genial hearty good fellow. Sir Francis has also made a name for himself. His works will exist when this generation has passed away, and his name will be handed down to posterity among the great artists of his country. I now turn last, but not least, to the genial Laird of Kilgraston. No mean artist himself, a keen golfer, a first-rate sportsman, in every good work always ready to assist by advice and example, he possesses all the qualifications of a true country gentleman. Nor must we forget the amiable lady who presides over 
the fireside at Kilgraston, and by her gentle influence diffuses pleasure to all around her."

The following anecdote is told of John Grant. A lady said to him, "Sir Francis is a great painter, Sir Hope is an accomplished musician-what can you do, Mr. Grant ?" "I managed to be their elder brother, and that is what neither of them can do!"

I had an allowance of $£ 300$ per annum. I had a private servant named Thomas Smailum. My batman was named Jenkinson, a big, good-looking man. He was paid two shillings and sixpence a week. His wife did my room, washed and mended, for two shillings a week. My room was in the back of the barracks, and I could see Fife and Charleton out of the window.

I began to hunt in earnest when I joined the $9^{\text {th }}$ Lancers at Piershill in I 8,36.

The first day cub-hunting the Duke of Buccleuch's Hounds met at Craigmillar Castle, and found directly (it would bother them to find a fox there now). Williamson was huntsman and Hugh Burns was first whip. The men wore cut-away coats, and all rode with snaffle bridles and martingales. Old Frank Collinson, who rode the young horses, wore a cap and a red "spencer," a short round jacket like a strapping jacket.

The following were the packs of hounds in Scotland at that time :-

"The Duke of Buccleuch." Huntsman, Will Williamson; whip, Hugh Burns.

"Fife." Whyte-Melville and Captain Wemyss. 
Huntsman, John Walker; whips, Tom Batters and Will Smith.

"Lothian." Huntsman, Lord Elcho ; whips, Joe Hogg and Bob Carlyle.

"Linlithgow and Stirling." Master, Ramsay of Barnton; huntsman, Kit Scott; whip, Tom Rintoul.

"Lanark and Renfrew." Huntsman, 'Lord Kelburn; whips, Jim Harrison and Sam Graham.

"Perthshire." Murray of Abercarnie. Huntsman, Arber; whips, John Hall and John Harvey.

"Forfarshire." Huntsman, Mr. Dalyell of Lingo; whip, Jack Skinner.

"Aberdeenshire." Huntsman, Lord Kintore; whip, Grant.

About April, I837, we marched to Glasgow, and were relieved by the I 4 th Light Dragoons, commanded by Jack Townsend. Two Dohertys, Robertson of Foveran ("the Whisperer"), etc., were in the regiment. The horses had bobtails.

On the Queen's accession to the throne we fired a feu-de-joie on Glasgow Green.

There was no riding-school in Glasgow barracks. The young horses and recruits were at Hamilton. We often went over there to play cricket.

The 42nd Highlanders were also quartered at Glasgow, having come from Edinburgh, and their barracks were in the worst part of the town.

A battery of artillery were quartered in the cavalry barracks with us. ' Charlie Bingham was in command. He was a capital fellow and very popular. 
"Fatty" Sutherland joined about this time, $\mathrm{He}$ was seventeen years old, and weighed seventeen stone. He was in the same troop with me, and Fullarton was our Captain. Fullarton was about $5 \mathrm{ft} .4$ in., and on foot parade he had to stand between his two subalterns. Sutherland was about $6 \mathrm{ft} .1$ in. and $\mathrm{I}$ was $6 \mathrm{ft} .3$ in. and right-hand man of the line.

At Glasgow Fair there were two giantesses (Americans) in a booth. I was put between them, being the tallest man in the place. I could just reach the tops of their heads.

In August Ralph Anstruther invited me to go and shoot at Braemore. John Dalyell and Hamilton Anstruther were the rest of the party. I went on the mail, and drove it part of the way, through Dingwall arriving at Dunbeath at three o'clock in the morning. Next day I got a cart and pony for the luggage, and walked to Braemore.

The year I 837 was the last the Fife Hounds went to Forfarshire. I had four horses- "Charlie," "John," a grey horse and a grey mare. The club assembled at Sandy Ross's hotel in Forfar. The horses were kept there, and the hounds in a timberyard just outside the town. Walker (the huntsman) lived at Sandy Ross's, and the waiter, an old redheaded man, was the earth-stopper. Old Lord Panmure presided over the first dinner. James Rait, John Kinloch, Balfour Oglivy and Archie Douglas were there. Admiral Wemyss, John Whyte-Melville, Fred Wedderburn and myself 
came from Fife. About eleven o'clock, having eaten and drank more than was good for me I went to bed. I was told that about three in the morning the chairman slipped off his chair, and as he was so fat they could not pick him up again ; so they put some pillows under his head, and left him there till morning. They then got him into bed, where he remained all day and all night, and went home in his carriage at 3 P.M. on the following day. He was very hospitable and kind, and I often spent a happy time at Brechin Castle.

Archie Douglas was a grand sportsman and a first-rate horseman. About 1826 he was sent for to ride a steeplechase at Melton-I think against Captain Ross-but he did not win it. Latterly he was very deaf. Once at dinner Lady Panmure said, "Will you have some fish, Major Douglas?" He replied, "We had a capital run to-day". When quite an old man Lord.Rosslyn, M.F.H., gave him a mount one day in Fife. We met at the New Inn. Peter Paterson of Carpow said to him, "Douglas, that horse is a capital fencer". He replied, "I'll try". The first fence was a ditch, a wall and a hedge. 'He cleared it all and:went on with the hounds alone.

In autumn : I got out hunting a few times with Lord Kelburn. He hunted the hounds himself. Will Smith was his kennel huntsman, who had been in Fife the previous : season, and whipped-in to Walker. It was a tremendous hard winter, seven weeks of / frost, and all the roads blocked with snow. The first day after the frost Lord Kelburn's hounds VOL. I. 
met at Erskine, Lord Blantyre's place. Power lent me his grey mare to hunt, and Hope Grant lent me a thoroughbred horse to ride to covert, and gave me a silver pocket flask.

Lord Kelburn was very keen and full of zeal, but he was too irascible for a huntsman, and his language was by no means parliamentary. His field were so frightened at him that if he turned back going along the road, they would all jump out of it to get out of his way. Mr. Whyte-Melville was out hunting with him, and followed him down the ride in a large wood; presently Kelburn trotted on to where his second whip was standing, and gave the lad a good double thonging with his whip. Melville quietly turned round and rode out of the wood.

In I 838 Willie Campbell of the Bays was the best gentleman-rider in Scotland.

In the spring of 1838 I rode to Bogside Races. Johnstone lent me a restive black horse. I sent "John" on half-way, and rode him on to the course. Jim Fairlie had a great raw-boned horse called "Splendour," and Sir David Baird a bay horse called "Wings". Lord Macdonald also rode in the races. Bob Richardson (General Richardson Robertson) rode "Zohrab," a horse of Jim Fairlie's, and Tommy Dallas a grey horse called "Pyramid".

On the 3Ist May, 1838, we marched up to Nottingham, and headquarters went to Leeds. I think Fullarton was in command of the squadron, and Andrew Spottiswoode and I were subs.

When we crossed the bridge on the border the 
men gave "Three Cheers for Old England ". When we got to Penrith Spottiswoode and I went for two or three days to see Ullswater, and rode to Patterdale and Lowther Castle and rejoined them at Kendal. A troop of the ${ }^{1} 5_{\text {th }}$ Hussars were quartered at Clitheroe in Lancashire, who invited us to dinner.

Lowndes was one of the officers. He was rather a rat-catcher. During dinner he said, "Should you like to see a regular up-and-down fight?" "All right," said we. A stable sentry came in without his jacket with a rat-trap and a ferret. The rat was let loose' and we all stood on chairs. After it had run about for a little the ferret was put down. It put its nose to the ground, lashed its tail about, and galloped off just like a little hound. Presently it came to the corner where the rat was and it began to squeak. The ferret ran in, caught it by the neck and killed it. We sat down and finished our dinner.

On arriving at Nottingham we put up at the Ram Inn. The landlord had formerly been messman to the 9 th Lancers.

I used to drive the "Commercial" coach to London whenever I went. Sam Taylor was coachman. 
CHAPTER V.

QUEEN VICTORIA'S CORONATION.

I WENT up from Nottingham for the Coronation; the first time I ever travelled on a railway. The NorthWestern line was open to Denby Hall where there was no station, and they drove the coach up to the side of the rails in a grass field, shoved it on to a truck and took it bodily up to London. The only refreshment-place was Wolverton, and the only refreshment hot elder wine and "parliament" ginger-bread.

Not having a ticket for Westminster Abbey I did not take my uniform with me. On arriving in London I found they had got me a ticket, but I had no means of getting the uniform in time. My sister Mary went with my uncle, General Sir Frederick Adam. My uncle, Sir Charles Adam, was at this time one of the Lords of the Admiralty, so we were allowed to get on to the top of the archway in front of the Admiralty to see the procession.

My sister wrote the following account :-

" Dover Street, Friday, 1838.

"My Dear Jean,-

"As it has begun to rain, I think I may find time to write to you and tell you about our gaiety, so expect a regular journal of nonsense. 
"On Monday I went with Aunt Charles to Lord Fitz-William's ball, which was very beautiful, and I liked it. I saw more people than I expected to know, and had some dancing. I saw John Balfour who had heard from Tina. I danced (as I suppose Louisa likes particulars) with Captain Grey and Frederic Romily and Edmund Elliot's brother, and a German attache of Prince Puteybuss. The Elliots and Listers were there. In short, it was much better fun than I expected; there were thousands of foreigners, which makes a ball more amusing. Soult was there and the Duc de Nemours, who is very good-looking, and is supposed to wish to be King of England. I was introduced to the Duc de Vicennes, who has brought over his own hairdresser and his ami, Count Pralin, and the Baron von Gottsch, the German.

"On. Tuesday we went to a party at Lady Minto's. Uncle Fred went also (very pleasant I thought, though that is a disputed point); and after it we went to the Highland Ball (not Uncle Fred), but Ann and William Elphinstone joined us. It was capital, such numbers of Scotch people. Lady Keith and Emily in a very pretty fancy dress, the Hume Drummonds, Mrs. Pitcairne, the Randolphs, Jane Dalyell, Alexander Carmichael, Augustus Hamilton, Mr. Gibson Craig, the Montgomeries, Lord Elibank and brothers-in short, plenty of people we knew. I forgot to say that the Duchess of Gloucester was at Lord Fitz-William's. He gave the ball because 
Lord Milton is going to marry Lady Fanny Douglas, Lord Morton's daughter.

"At the Caledonian Ball there was the Duke of Sussex, Prince George, Princess Augusta and the Duchess of Cambridge, and numbers of noblemen, beginning with Duchess Maggy. ${ }^{1}$ Tell Louisa Mr. Douglas Stewart was there, having been so ill and looking so. We were quite tired of reels and bagpipes, but the thing most worth seeing was Prince Zichi. His coat is all embroidered in turquoise, the whole of the front and cuffs, and the buttons are, I think, nearly as large as blackbirds' eggs, studded with turquoise. The feather in his hat is quite full of them, and his sword is quite superb, and he has some on his leggings, I think-in short, I did not think one man could have put so many on, it was like something in the Arabian Nights. There were numbers of foreigners, all so polite ; one could hardly move for the giving one seats and bowing. One with whom I danced led me to the quadrille by the tips of my fingers, much to my amusement. I saw Mary Kerr.

"For a week nearly there has been no moving in the streets. The town is so full and people so mad, and they put up barriers at the ends of the streets to prevent a crowd in the procession at the Coronation, so that only one or two carriages could pass at a time. We stood one hour and ten minutes on Monday near the Park Gate without being able to move, and all the small streets are as full as the large ones generally are.

${ }^{1}$ Duchess of Somerset, née Shawe Stewart. 
"All Wednesday I was in a state of excitement as to whether John could come to take me to the Coronation, as I had two tickets for the gallery above the north transept. Uncle Fred, who did not intend to go, remained in town instead of going to Richmond Park, in case John should not come in time, which was so good-natured, for he would much rather have stayed at home. On Wednesday night, after I was in bed, John arrived, having had great difficulty in getting leave, and came off so quick that he could not bring his uniform. So he was in despair, and sat up for an age, sending to his tailor and Captain Williams and all the world, in vain, to try to get a uniform to go with me. However, he could not.

"At a quarter to five Uncle Fred and I set off, he in full uniform and such a number of orders, and me having trimmed my last year's tulle gown with gold vine leaves, and got a wreath of gold leaves for my head. We got into the line in Regent Street, and got to the Abbey after six. On the way Lord Glenelg saw my uncle, and gave him two tickets for the choir gallery, thinking we should see better. When we got into the gallery we could see nothing, and only be made deaf with the organ; so Uncle F. went to see if he could manage to put me among the Privy Councillors, but that would not do. Mr. Gray and Mary Anne were in the same scrape. At last Uncle F. and I went to the gallery above the north transept and opposite the peers. We were so high up we could hardly make out faces, but we saw the throne, and the place where the Queen sat when she 
first came in. There we sat from six till twelve, when the Queen came. We could not see the altar, but saw her come in and sit down; and then she went to the altar, and we saw the Bishop of London preach a sermon; and then all the peers shouted, and we saw them put on their coronets when she was crowned at the altar, which we did not see. It was a beautiful sight, but the music is rather lost in the Abbey. Back came the Queen from the altar, wearing the crown, and sat down in her chair; and the Archbishop read something, and she got up and walked to the throne, all the Dukes' daughters bearing her train, and she seated herself on the throne, all the people shouting, and the music also ; then all the nobles did her homage, beginning by her two uncles. They first touch the crown on her head, then kneel down and kiss her hand, but the Royal Family kissed her cheek. When the Duke of Sussex knelt down he was a long time, and said something to her, and she bent forward and gave him a kiss. They cheered for such a time when the Duke of Wellington did homage, and waved handkerchiefs. (I was so glad.) " Old Lord Rolle is so old he tumbled down in going up the steps to do homage. They say the Queen started off her seat, but I did not see it, though there seemed to be a great commotion for a moment. While the peers were doing homage we went round to the south transept to see the peeresses, who looked most splendid. After that we could not see the altar, and it was nearly over, so we went down the House of Commons back stair, and got 
over to Westminster Hall to get the carriage, but found it would not be up for an hour and a half. So we walked round the outside of the Abbey, and saw all the mob and guards and got into the nave, a long, immense passage by which the Queen and peers enter, lined with guards and men-at-arms, which I should never have seen except for being with my uncle. Then we met Sir R. Otway, who went and asked Sir Frederick Rowe's leave to cram one young lady into the place near the door of the Abbey, where all the old Generals and Admirals were. Sir F. Rowe said I might go if they could manage it without his having to give leave, so in I went to the Abbey again (before the peers had finished doing homage) and was put among such charming old heroes, all of whom one has heard of. There was no other lady near, so I felt rather queer. However they put me in a good place in front, and told me ' not to be in a fright, as there were plenty of soldiers to defend me'. I found Sir Philip Durham ${ }^{1}$ there, and they were so good-natured to me. The Queen passed, and all the suite, quite close to us as she went out, so three of these old heroes told me who every one was. The Duke of Wellington stopped to talk close below as he went out, and Lord Melbourne, so I took a good look at him. Soult and all the foreign Ambassadors, Turks, etc., etc., passed close. Soult was well cheered, thanks to Uncle Fred, who gave the first cheer for him.

${ }^{1}$ Admiral (of Fordel). His brother, General James Durham, married my aunt. 
"After they had passed we stood among the peers till they went, and then went to look at the altar, and then tried to get away in vain. So at last the police said we could walk quite well to the Admiralty. So off we set, gold wreath and white shoes, with a policeman before us to make way. We had some little trouble, as we did nothing but meet bodies of guards going in different ways, but they let us pass between their ranks. We got on so well that we bid the policeman good-bye, and got on quite well till we came to the end of King Street, where we found a crowd and numbers of tipsy women. However we got through, thanks to the police, and got on till past the Horse Guards, so there we were fairly stopped. The mob was quiet, very polite, but seemed to think us great fun. The procession I believe had caused it, as it had not quite passed, so there we were close to the Admiralty, but no hope of ever getting to the gate. Some gentlemen and an old Italian woman and man were very polite and kept the mob off me. Though they were quiet it was not pleasant to be in the middle of them in full dress and my uncle's uniform, so we were rather too much stared at to be agreeable.

"At last, seeing the Admiralty was hopeless, my uncle thought we might squeeze back a few steps to the Horse Guards, which, with the help of our Italian old body and man and some difficulty, we managed, and seeing his uniform they let us in. So I was put into Colonel Egerton's room till Uncle Fred got the gate of the Admiralty open, and he and Colonel 
Egerton took me to the garden. In crossing the office we found John and Willy going to take "Miss Apples" home, who looked amazed to see us there, as we were to have come straight here from the Abbey. Many ladies walked home, but after the procession had passed, and before. We found the remains of a large déjeuné and party at Aunt Charles's.

"I shall leave the procession to some one else to tell, as I only saw the Duke of Newcastle's carriage like some fairy tale. The horses were covered with blue satin bows, and blue satin ribbon manes. We got home here in the carriage in about an hour, and I slept a round of the clock. I never saw such a quiet mob. John and Captain Williams saw the fireworks and illuminations, which were quite superb; many ladies'did also, but we were too tired. Emily Montgomery went and saw, but was considerably alarmed at the mob, and no wonder.

"The Duke of Wellington gave a grand ball last night, so there was enough done.

"Mrs. Broke and Kate Muir and Glenace came to see us to-day, all looking so well. I don't know how long leave John has got, but I hear Lord Rosslyn has given him some; but he has gone to get it settled with Sir John McDonald. We go to the opera tonight to see the Puritani with the Montgomerys, who go to Scotland to-morrow.

"There is a fancy fair in Hyde Park to-day and to-morrow. We are going to see it-in short, every one is mad here. The foreigners say, 'Everything 
in dis contree vary parfit, but die crowd everywhere, a crowd ballroom, even-always a crowd'. I suppose they think it is always as bad as at present.

"Your affectionate

"Mary A. Thomson.

"Uncle Fred thinks of going to Scotland on Wednesday or Thursday. The only thing I was sorry for at the Coronation was his going with me instead of being in his proper place as a Privy Councillor.

"I believe I have left out words and made many mistakes in my letter, but have no time to read it again. I hope Granty keeps better since he went to Blair. John stays till Thursday, so I don't know when we go to Richmond Park, as it is full ; besides John has numbers of friends in town and would rather remain.

"I was glad Clem did not go to the Abbey. She is better, I think, since we came. But it was such hard work, and even I had to stand on a bench on tip-toes till I could hardly move-many little people saw nothing.

"I think you will be tired of this letter, it is so long. Have you any commissions? I wish you could have been here yesterday, for I really did enjoy it. Tell Louisa that for once I could not sleep from excitement the night before the Coronation. Think of sage old me being such a goose! The opera to-night is the Puritani, so good. I expect that Albertazzi will sing the part Fanny Windham 
used. Tell Louisa old Mrs. Villiers is as goodnatured as last year, and Miss Lister's friendship continues. Anne Elphinstone is living at Kent House.

"I found Sir P. Durham among the old Admirals and Generals-most agreeable, and so fond of Teddy Adam. Col. Wemyss managed the procession."

[The writer was Mary, my fourth sister. She married the Rev. Ramsay Campbell, son of Sir Archibald Campbell of Succoth. Her daughter, Clem Campbell, sent me the letter.

"Dover Street."-She was staying in a lodging in Dover Street.

"Aunt Charles."-Wife of my uncle, Admiral Sir Charles Adam, who was one of the Lords of the Admiralty. Lord Fitz-William was grandfather of the present Earl.

"John Balfour" (of Balbirnie).

"Tina," his sister, now Mrs. Robert Ellis. She had gone to America.

"Frederick Romily" married one of the Elliots. Edmund Elliot was Colonel, 79th Highlanders.

"Elliots."-Daughters of Lord Minto. He was First Lord of the Admiralty. Lady Minto and Lady Adam were sisters.

"Lister."-Lord John Russell's first wife was a Lister, his second wife an Elliot.

"Uncle Fred."-General Sir Frederick Adam, commanded a Brigade of Guards at Waterloo.

" Ann and William Elphinstone."-My mother's 
cousins. My grandmother was Hon. Eleanora Elphinstone, sister of Lord Keith the Admiral.

"Lady Keith" (in her own right) married Count de Flahault. "Emily," her daughter, afterwards Lady Lansdowne.

"The Hume Drummonds."-Late Duchess of Athol was one of them.

"Jane Dalyell."-Sister of Sir Ralph Anstruther of Balcaskie.

"Augustus Hamilton," Captain, (?) Highlanders.

"Gibson Craig," father of the present Sir James.

"Montgomeries."-James Montgomery married my eldest sister, Eleanor.

"Elibank," married Montgomery's sister.

"Lord Milton," late Lord Fitz-William, died I 902.

"Duchess Maggie."-Duchess of Somerset, Margaret Shawe Stewart.

"Apples."-Miss Applebee, my sister's governess.]

Lord Rosslyn lived at Gedling, a house of Lord Chesterfield's, and was in command of the regiment.

In the autumn of 1838 I was sent from Nottingham to Derby, where we had one troop in billets. Percy Williams was Captain, and Spottiswoode and I subalterns. Percy Williams spent most of his time at Melton whenever he could get away. We lived in a little house in the Osmaston Road, and our chief allies were Peter Colvile and Jack Story of Lockington. He then lived at Spoondon, and was after- 
wards master of the Donnington Hounds. Colvile lived at a place called Duffield, six miles from Derby. He used to drive in and out in a trap with a little bay mare. He often came in to dine with us. Spottiswoode's brother-in-law was Lord John Scott. He lived at Causton, near Rugby. He one day sent us a hare, so we gave a dinner party and had a carouse. Our guest was Peter Colvile, and he dined in Spottiswoode's dressing gown. When it was time to go home he put on a forage cap, got into the buggy, put his legs into the boot, and his back to the splashboard, twisted the reins round his hand and put his hands in his pockets. At daylight Poyser, the old butler, found him at the gate at Duffield in the same position.

One day the Meynell Hounds met at Kedliston Inn. I saw a thin solemn man standing holding a good-looking brown horse which I recognised as Ellis's, who was quartered at Nottingham. Later in the day my horse leaped into a new-made drain and fell, and the solemn man nearly jumped on to me. The rider was Captain Mildmay Clark, afterwards my greatest friend in the Pytchley country. $\mathrm{He}$ and Ellis had been together in the $\mathrm{I}$ 6th Lancers.

Hugo Meynell was then a schoolboy and used to come out on a black pony, and Jack Leedham, the second whip, used to look after him.

About this time John Madocks joined-my dearest friend all the rest of his life-the picture of a soldier and a gentleman, very good looking and strong as a horse, about $5 \mathrm{ft}$. I I in., like Prince 
Albert, but more manly looking and more expression. A first-rate horseman, capital cricketer, could run like a stag, full of fun, very popular with everybody, and the best-dressed man in the regiment. $\mathrm{He}$ came from an infantry regiment, the 68th I think. About Christmas I was sent to Nottingham.

On the 2oth April, 1839, my grandfather died. I came from Nottingham to attend his funeral at Greyfriars Church, Edinburgh. After the funeral, as I had a few days' leave, I went over to Charleton with my sister Louisa.

The hounds met one day at Auchmore Bridge. I rode over to Leslie, and Lord Rothes lent me a capital little horse called "The Barber". They had a capital run over the top of Benarty. The frost was, not out of the ground, and galloping on the side of the hill, "The Barber" slipped up, and I broke the small bone of my leg just above the ankle. James Johnstone of Alva came to help me and got me on the horse again, and I rode down to the Blair Adam Inn, put my leg into a bucket of hot water, got some eggs and bacon and sent to Kinross for a post-chaise and for Dr. Gray, who had attended us at Blair Adam when we were children.

I was moved to Kirkland's Inn at Kinross and put to bed, and my sister Louisa was sent for. I think she came next day, and the day after we got home to Charleton.

About the same time my special friend and playfellow at Nottingham, John Madocks, was out hunt- 
ing with Fred Isaac. They were engaged to dine out, and so were anxious to get home. There was a short way to the barracks across the park, and an iron-bound gate which was kept locked, but a man was usually there with a key. This time he was not there, and as they were in a hurry Madocks says, "Ikey, will you have a shy at it ?" He said, "All right, go on ". Madocks rode at the gate, his horse caught it with his knees and turned right over, falling with his hip bone on the middle of Madocks's back. It was just opposite the "Admiral Warren" publichouse, and some people came to his assistance and got a door to lay him on. I saac galloped away for the doctor. By this time Captain Little had arrived, and Madocks said to him, "It's all up with me, Corporal". He answered, "Not a bit, my boy, you're worth a dozen dead ones". He was carried into barracks, and it was found that his os $\operatorname{coccy} x$, the lowest bone of the spine, was fractured. If it had been an inch higher it would have been fatal. He was laid up many weeks, and could only move his shoulders by lifting himself by a rope fixed to two crossed lances. But eventually he got quite well. During this season we hunted with the Marquis of Hastings, who then had the Donnington country. Will Head was his huntsman; Jack Ransom first whip. The Marquis was a very charming man, and very hospitable to us. Old Jack Masters had the South Notts. Markwell was his kennel huntsman. We often hunted with him.

One day I was out with the Belvoir when Lord VOL. I. 
Forester was master and old Goosey huntsman, and sometimes with the Quorn, with Lord Suffield, master; Charles Treadwell, huntsman. He bought Sir Matthew White Ridley's hounds. It was not a successful season, and at the end of it the bailiffs came and seized the hounds, Lord Suffield being bankrupt. Mr. Robertson of Lady Kirk bought them, and engaged Treadwell as his huntsman, and hunted Berwickshire.

We went to Norwich, and soon after our arrival there was a sale of all Lord Suffield's things at Gunton. Archie Little and I bought four guns, one of which I have now.

Our principal amusement was cricket, and there was a capital club at Blickling, to which we went once a week. We also started a coach. In the winter we hunted with Lord Sondes and Sir Jacob Astley. Chapelow was huntsman; Harry Taylor and Brett whips.

In the year I 839 I got my first and only lesson in gambling. We went to Newmarket Races, and Little, Willoughby, Isaac and I posted up to London to go to a "hell". We arrived about 10 P.M., and went to the "Cocoanut Tree," either in Haymarket or Waterloo Place. We sat down, Willoughby next me, and rattled the dice, and called "Seven is the main," but the dice never turned up right. I lost $£ 25$, and said to Willoughby, "This is d-d bad fun-I'll have no more of it". He said, "I agree with you". So we stopped and never played again, and got our lesson cheap. We got into our chaise, 
and posted back to Newmarket in time for the races. Willoughby went to India with the regiment, and died there.

This year the order came out that cavalry soldiers were not to shave their upper lip. When William IV. came to the throne the 9 th Lancers were at Hampton Court, and the escort were ordered to cut off their moustaches. This was in 1830.

On 25th April, I840, the regiment marched to Hounslow. There was a little barrack at the gate of Hyde Park at the top of Queen's Gate. The regiment at Hounslow had to furnish thirty men and four corporals and one sergeant to do the orderly duty and escorts in London, and I, being senior subaltern, was stationed there.

I was presented to Her Majesty Queen Victoria by Lord Rosslyn at one of the first levees.

I had all the picked men of the regiment and picked horses. They were a real fine lot of old soldiers. In those days they enlisted for twentyfour years. Many of them were six feet high, and in stable dress they looked like lifeguardsmen. My sergeant was a very smart chap named Nile, who was always for making a good appearance. They were all men of good character. The only punishment was to be sent back to the regiment, and it never happened all the time I was there. One chap was taken ill and was afraid he would be sent to hospital, so he took eight ounces of salts in eight doses! We had to send four men and a corporal every day to the Horse Guards. Lord Rosslyn's 
orders to me were, "Inspect every party yourself, and attend to the shoeing". They paraded at nine o'clock, so I cut out before breakfast and sometimes back to bed.

Lord Rosslyn lived in Grosvenor Place and rode down to Hounslow almost every day. My rooms were on the ground floor, and sometimes he tapped on the window with his whip before I was up and called out, "Do you want anything?" "Corporal Horne's horse did not trot on escort yesterday." "Send him back, and I'll send you another."

My first escort was from Buckingham Palace to Claremont, about fourteen or fifteen miles. I had a great big high-stepping bay horse called "Cannibal," and all my escort were about the same pattern. We were drawn up at the gate of the palace facing inwards, six men on each side, officer on the Queen's side, sergeant on the other. When the carriage left the palace door two first men moved off, then about a hundred yards behind them four more closely in front of the outriders. When the carriage came the officer saluted and took his place, the sergeant on the other side. The Queen looked me over from the top of my plume to the soles of my boots. The other six closed in close behind the carriage. It was a Saturday afternoon, and pretty hot in those days. We wore overalls, trousers and Wellington boots; and the blood ran through the knees of my overalls before the end of the journey. Our lancer caps were an awful weight and top-heavy.

The carriage horses were changed on the top of 
the hill above Kingston, which gave our horses a moment to get their wind. The Royal carriage goes about ten miles an hour. We then went on to Claremont and marched back quietly to Kingston, where we were billeted for the night.

I went back to Claremont in a cab, where there was dinner in the ante-room for the officers of the guard of honour and escort. I forget who they were, but the Hon. Charles Murray, who was comptroller of the household, came and talked to us. We went back to London on Sunday evening after dinner, and it was quite dark when we got back. I reported to Lord Rosslyn that it was too long a job for troop horses, and he arranged that they should be relieved every six miles.

Relieving escort was a very pretty sight. The new escort was formed on each side of the road facing inwards. The two leading men of the old escort formed up on the new escort, and the two leading men of the new escort broke away, and so on in succession without any check in the pace of the carriage.

A lunatic named Oxford fired a pistol at the Queen's carriage one day while driving in the park. Soon after this I had the escort for six miles out of London. The park was lined with carriages and crowds of people cheering, and the school children threw flowers on the road in front of the carriage, and the Queen wept and sobbed the whole way. After this we were ordered to ride close to the Queen to protect her person. 
CHAPTER VI.

HAMPTON COURT AND DORCHESTER.

IN I 840, when I was quartered at Kensington Gate, in the 9 th Lancers, my uncle, Sir Charles Adam, was one of the Lords of the Admiralty. My sister Mary lived with them all that season. Lord Minto was First Lord. Lady Adam and Lady Minto were sisters, and my cousin Mary Adam (afterwards Mrs. Lindsay Antrobus) was about the same age as my sister.

I had lots of opportunities of attending parties and balls, as I was often included in their invitations. At that time Almack's was all the fashion, and Lady Willoughby d'Eresby was one of the lady patronesses. She was my mother's cousin, and was very kind in giving me tickets. There was a good deal more formality in those days. You asked a lady to "do you the honour of dancing with you". Quadrilles were the mainstay; no lancers, no gallops, no polkas, no flying about with deux temps. Waltzing was a solemn proceeding: a pirouette-one, two, three; one, two, three. Charles Mathews (the famous actor) in a play about that date, in a song, describes a ball: "You look down at your shoes, and glide about like melancholy kangaroos." No sitting 
out, or flirting in the corners; when the dance was over the young lady was marched straight up to her chaperon, and handed over to her with a low bow.

The first time I saw a polka danced was at Leamington in 1843. A chap named Bradshaw danced it, and everybody looked on. When we were quartered at Exeter we got a bandsman with a flageolet to stand behind the screen in the messroom to play for us while we practised; and we soon became pretty good at it.

2oth June, I 840.-When quartered at Hounslow, Frank Willoughby and I were driving a gig to London with "The Flying Horse," and going about sixteen miles an hour, when we met a tax-cart in the middle of the road. We were on the right side, and I believe the driver of the cart pulled the wrong rein. We went crash into it, broke both shafts, and were shied out. The horse ran away and was captured somewhere in Turnham Green. I pitched on the back of my head and cut a gash in it ; Willoughby landed on his nose and cut it badly. We had just scrambled on to our feet when a beastly man ran up and gave us in charge of a policeman for furious driving, so we were marched off to the police office. The policeman was a very good fellow and rather spoke up for us, as we were on the right side of the road, and the inspector released us on payment of $\notin \mathrm{I}$ to the man in the cart, as some of his harness was broken. He had come from Windsor with the Queen's plate.

We got a fly and went on to Limmer's Hotel, and 
then tried to get some one to doctor Willoughby's face. The man at the chemist's shop looked out of the window and thought we were chaffing him, and we had great difficulty in persuading him to come. I saw stars for a little while, but Willoughby was on the sick list for several days.

One night coming up from Windsor on Watkin Wynne's coach with a team of post-horses I was driving and going about fifteen miles an hour. At the turnpike gate at Brentford there was a waggon between us and the light, and I was close to the gate before I saw it. I said, "Catch hold of the whip, Pat, I can't stop them !" I reached my right hand down, got a good grip of the reins, and pulled them well together. The leaders half rose at the gate and caught it with their collars, and burst it open. There was no harm done, except our main bar broke, but we had a spare one and were off again in two minutes.

On 16th August I went on leave, and got my troop before I returned. I was at Hounslow the rest of the season and hunted with the Queen's staghounds.

Sir John Halkett was living at Pitfirrane in I84I. The Fife Hounds were at the Green Inn, Kinross. I was staying at Blair Adam, and also Jim Montgomery; John Grant and John Whyte-Melville at Broom Hall. I forget where they met, but they ran through Dhu Craigs to Tulliallan. I was riding "Cannibal" and got into a bog, a real bad one, and there was nothing sticking out except his head. 
Presently I saw Walker and Stephen Goodall trotting along the road over the moor about half a mile off. Walker said, "Stephen, see that-that's Sir John" (thinking I was Sir John Halkett). "That's what will happen to you if you don't mind where you are going," and trotted on without taking any further notice of me. Presently Mr. Whyte-Melville appeared, and he was more charitable and came to help me. A girl came from a cottage and said, "They once had a coo in it". Then Jim Harrison came, whose horse had shut up. At last we got "Cannibal" out by digging bits of turf and putting them under him, but he was dead beat when we got him out.

26th January, 1841.- The regiment was still at Hounslow. I was at Leamington on leave in January. There was a prize-fight between Jack Hannan and Johnny Broome somewhere in Oxfordshire. We started with a team from LeamingtonJohn Madocks, Charlie Brooke, Clarke, Charlie Synge, and, I think, Billy Williams. The roth Hussars were quartered at Coventry. We changed horses at Banbury and also somewhere near Bicester. We passed Sir Henry Peyton's (Swift's house), drove across fields and all sorts of places.

The first part of the fight was very pretty. The men looked like marble statues, and every movement was graceful, and they were a long time before they hurt each other. Broome was a very handsome man, rather the taller and heavier of the two. Jack Hannan had a real fighting mug. The fight lasted a long time and both men were much exhausted. Lord 
Queensberry said to Hannan, " How are you getting on, Jack?" "Werry bad, I sees two on 'em." "Then knock one of them down," said Queensberry. He had at last to give up, and, I believe, broke a bone in his hand. As he got into the chaise to go away, he was holding his hand and saying "My poor 'and".

Getting home was a job. There was a string of carriages, and on a sudden stop just as we were crossing a bridge at a gateway, our off wheeler's hind leg slipped into a ditch, but when we went on the other horses pulled him out. One of the leaders got so done that we took him out and turned him loose on the road, intending to go on with a "pickaxe". We gave him a pint of sherry. When we started some one blew the horn and he trotted on. He ran before us for two miles. We then caught him and put him to again, and we got back to Leamington late at night.

28th January, I84I.-We had a steeplechase at Southam when I was on leave at Leamington.

Piers Mostyn, first.

John Madocks on "Creole".

Edward Mostyn, 8th Hussars, on "Seventy-four".

Chas. Brooke.

Billy Williams on "Coronet".

Robertson (Foveran).

J. A. T. on "Prisoner".

I think the weight was thirteen stone. I reduced myself to I 2 st. $8 \mathrm{lb}$., in my shirt about three days before the race; but I got tired of starving and 
drank a pot of porter, and was a good deal overweight. My horse was a very hard puller and not very fit. I was obliged to make the running, for my horse would not be denied. He jumped the first three or four fences beautifully. Andrew Robertson then came alongside of me. The next fence was a wall rather up hill. His horse refused it and so did mine, but I turned him round and got over all right and on to the brook, which he jumped like a bird. The journey was about half over when I felt him collapse, and all the others in a ruck caught me. There was a grip running slant way down the field, and I could not get my horse to cross it. He ran down it to the end of the field. Billy Williams bumped Charlie Brooke here and said, "Beg your pardon, old fellow". "Go along, this is no time for buffoonery," was the reply. Piers Mostyn was first. I forget how the others were placed, but I was fifth.

On 4th April, I84I, I marched from Hampton Court to Dorchester. I think that Little was in command.

The Exeter up mail used to go through Dorchester at 7 P.M. and return at 7 A.M. Bill Cherry was the coachman who went to Salisbury, forty-four miles and back. We arrived at Salisbury about I I.30, used to lie down and sleep till 3.40 A.M. and then off again.

I used to go about twice a week, and it was grand going over Salisbury Plain, just when it was getting daylight. The proprietors got to know me pretty well, and made no objection to my driving. 
I took my chance, heavy loads or light, and got practice which was useful to me ever afterwards.

Poor Bill Cherry a few years after (when the rail was opened to Southampton, instead of going to Salisbury the mail went through the New Forest) got off the road in a fog and upset the coach. It fell on his head and dashed his brains out.

I $3^{\text {th }}$ April. - The day after arriving at Dorchester I got out roe-hunting with Major Shirley's harriers at Milton Abbas. I rode "Cannibal" and mounted Spicer on "Viceroy". Had one day with Farquharson at Moreton, and one more day roehunting, and that finished the season.

I had got my troop before the regiment left Hounslow, when Whalley retired. It cost $£ 5$,, 00 . I insured my life for $£ 5$,000. I have been a good bargain for the Insurance Company as I have paid $£$ I I9 for sixty years.

At that time the regiment was under orders for India. One night when I returned to barracks at 7 A.M. I found John Madocks in my bed. He had come up from Exeter. I laid down on the sofa and went to sleep. By-and-bye he said, "Where have you been, and what have you been doing?" I said, "I have been to London to see about an exchange, and I mean to go into the Carabineers". "Oh, $\mathrm{d}-\mathrm{n}$ it, no. Don't be a heavy, and wear a brass hat." I said, "The only other regiment in which there are any vacancies is the $\mathrm{I} 3^{\text {th. There is a }}$ Captain and Lieutenant who wish to exchange." "Let's go together wherever we go," said he. "All 
right," I said, and we wrote at once and effected the exchange. I exchanged with Captain Reid and paid $£ 1,500$ for the exchange, making my troop cost $£ 6,500$.

From Dorchester my troop was sent to Maiden Newton during an election, in July, I84I. I was in London, and came down on Sunday morning by the mail, arriving at 7 A.M. I got a hack and cantered off. Meeting a boy on the road I said, "Is this the way to Maiden Newton?" "It wor, but 't wor burned down this morning."

I quickened my pace, and on arriving there found twelve or fourteen houses burned down, and if my men had not been there it would have been burned down altogether. All the garden walls were built of mud and thatched with straw, which they call "cob" walls, and the fire ran like lightning from house to house. My men were marching to church. A chap was frying bacon, and some one shouted, "Come and see the soldiers". He upset his pan, the grease flared up, and set the chimney on fire.

Nicholson was with me, and we were kept there about a month. Before we left the authorities gave us a supper and a sum of money to pay for new overalls for the men.

24th September.-First day of the season I 84 I. Drax's hounds met at Stock House. John Last, huntsman. Farquharson was Master of Hounds in Dorsetshire. He was very like old Keate of Eton. He had just lost a son in the 7 th Hussars, 
and was very down. Jim Treadwell was huntsman. One of the whips called Penny was nearly black.

Old Lord Portman came over one day to try to persuade old Farquharson to give up some of his country, but he did not succeed. He was very kind to me, and I went often out hunting with him, and stayed at Langton. I met old Billy Butler, the sporting parson, who was a friend of George IV. He rode thoroughbred horses, and was followed by a groom in a blue coat down to his heels. One day about luncheon time he said to his servant (they were standing in a turnip-field at the time, hounds drawing covert), "Jan, gi'e me a turnip". "Maester, they be Swedes." On I 2th November I went on leave.

The 9th Lancers went to India in 1842 , and served all through the Indian Mutiny under Sir Hope Grant. The following notice appeared in the Times on their return :-

"The remaining squadron of the 9th Lancers, which had been sent for the morning previously, had joined us from Bareilly, and the regiment was now complete. It would be unjust to officers and men if one were to allow them to pass without a word of praise for their appearance in the field and their efficiency in all points. They have been now sixteen years in India, and it would be difficult to find any cavalry regiment in the world which could compete with them in all the qualities which constitute a perfect service regiment. Notwithstanding 
the sickness from which they have suffered during their long-continued and arduous duties, the squadrons are tolerably strong, and horses and men are in good condition, although the former seem occasionally to overweigh their chargers, all of them being tall and muscular men. Most of the troopers have seen much service before Delhi, and under Sir C. Campbell they have acted as cavalry, as infantry, as artillery, and as military train ; and the quickness with which they turn out, after a long and dusty march, in clean white cap covers and pantaloons and well-brushed jackets, with horses well-groomed and polished accoutrements, shows that the men have a soldierly pride in looking smart. They have taken the flag off their lances, and many of the men have substituted the long bamboo used by the native Lancers, instead of the ash shaft according to regulations."

About the beginning of September my uncle, Sir Charles Adam, went out as Admiral on the West Indian station. My sister Louisa went with Lady Adam and Mary (afterwards Mrs. Antrobus). Captain Katon was his Flag-Lieutenant. They went out in the Pique-Captain Boxer. Harry Loch, the late Lord Loch, was a midshipman. I went down to Southampton with them and stayed on board two days.

My sister Louisa was on board the Admiral's flagship, and she wrote the following letter :- 
"Bermuda, I7th December, 1844.

"No. 95. Thermometer $60^{\circ}$.

(Shivering, and got a fire.)

-. "Now, let me consider what we have been doing for the last month. On the 24th there was the most beautiful eclipse of the moon I ever saw; it lasted upwards of an hour. Then we have been riding a little and sailing, and having people to dinner; but not Bermudians, only officers of the army and navy. Captain Scott is a comfortable sort of man, who seems as if he belonged to us, and Captain Sturt of the Rose is a prim, pleasant, oldish man. He is either brother or cousin to the Mr. Sturt that married Sir R. Sale's daughter. I do wish you could see a boat-race here. We were four hours sailing in the Hebe without being tired. There were upwards of fifty boats sailing in every direction, and the racing-boats like white fairies skimming along. The sailing boats, you know, are not open, but decked, so that you can stand and move about as much as you please. On the 28th we went to a subscription ball at St. George's. Uncle Charles excused himself. The day proved calm, so Mr. Katon drove the phaeton, in which went we three ladies; our goods went by water. We being grand had the garrison gig (which means a boat belonging to the officers) to meet us, so we sent it to bring our clothes, otherwise they would not have sailed in till eight o'clock, which was the fate of much of the beauty and fashion from this end of the island. We went to Colonel Hutchinson's, where 
we had a very nice room, but only one among us, as Mrs. Hutchinson has no drawing-room, but sits on the verandah, which did very well, as the night was fine. She has such little ducks of children, full of fun and ready to play with any one. After dinner we walked down a very dusty hill to the old town hall, which was clean and well lighted; a capital band, a superfluity of partners, and plenty of funny people to amuse us. A ball in a warm climate is so nice from all the windows being open; the only misfortune is that everybody walks, and brings in a peck of dust a-piece. There is a Miss Althea Tucker, like a very fat Georgina Hay, with curls all over her head, who danced fine steps to my delight, and a still fatter Humpty Dumpty, who boasted the name of Mrs. Washington. Frocks and tunics of all kinds and dimensions; very few pretty faces, and never a good figure. Next day my aunt and Mailly came home in the phaeton, going first to a ploughing match, for five guineas, given by my uncle. There were actually sixteen ploughs. There were only three six years ago, and the cultivation has improved wonderfully since we were here. The Governor and Admiral and all the big wigs were there. I had a four hours' beat, with the wind right against us, in the Hebe, having the two Miss Reids, one a nonentity, the other a great talker, Captain Erskine and Mr. Katon, so we were pleasant enough, and approved of our expedition very much. Then we have had visitors (ladies) staying in the house. I've vacated my room for Mr. and Mrs. Hallowell, and went VOL. I. 
to a small one made in the corner of the verandah for Willie, and Mailly gave hers to a stupid little Miss Oldershaw, an engineer's daughter, who she fancies she is very fond of, but she gets very tired of her, and returns to recover the fatigue of entertaining her. We generally have midshipmen on Sunday. So, altogether, without my uncle and aunt, we went a party of ten to fetch a walk, and met a party of nine from Government House. It is lucky we are a long mile asunder, otherwise, I think, they would try to run in and out.

"You can't get up races in Fife; but we are much grander. On the IIth we all set out for St. George's, after various doubts and fears. The morning being rainy, it cleared, and down we sailed in an hour, and this time we had a whole lodging-house to ourselves. Most of the Bermuda houses have the staircase entering the sitting-room (for coolness I suppose). This was a good large one and three small bedrooms off it; so John Erskine and Mr. Katon went to their friends at the barracks. We walked up to the racecourse, which was about half a mile round a field, and went into the stand, where we found the Reids, Hutchinsons, various officers, ladies and dockyard belles. Four started for the first race - The Ladies' Purse-but in the first heat Lord Mark Kerr, who was running, had a bad fall and was distanced. It was just in front of the stand; some ladies wept and some turned white, some red; but he was not hurt, only being very light, he carried three stone dead-weight, which was not pleasant to 
fall with. Mr. Ratcliffe, our next friend, rode beautifully, but had a bad horse. So Captain Crofton's won, rode by Mr. Autley, neither of whom we cared about. The fourth horse was a Bermudian's, with an American jockey, who everybody expected would do something unfair, as such things are allowed in America; but, on the contrary, he lost very goodnaturedly. Then there was a hurdle race, which Lord Mark did win, and a third race. This was all charming, and I could not help thinking what I would have given ten years ago to have seen so many certain and undeniable partners for the approaching ball. A new friend is Mr. Paget, in the Artillery, brother to the maid-of-honour, good-looking and conceited; never wishes to be ten miles from London, and always keeps his mouth open. Then there is dear, good-humoured Mr. Baring, covered with turquoises; and fat Captain Crespigny, and a silly Major Horne, and a solemn Captain Gordon of Park, and Captain Birdmore, with Valenciennes ruffles (is that the fashion?), besides all the sailors; and there is a rarity, a civilian, Mr. Kennedy, the flagship's eldest brother, visiting his uncle, who is Colonial Secretary here ; scarcely been out of Ireland, and so entertaining; he has been travelling, and has discovered why the Yankees eat so quickit is because they keep their mouths for eating and speak with their noses! All his discoveries are in the same vein with a strong brogue. We mismanaged our affairs sadly, except my aunt, who said she was tired and would dine on the cold meat we 
had brought. My uncle dressed, and we pegged up the hill to Mrs. Hutchinson's. It was then beginning to blow. We had a pleasant dinner; the verandah was uninhabitable, so went into the nursery to have coffee, and then were to walk all through the town home to dress. When I saw how pitch dark it was, and knew the difficulty of finding the way through lanes and wynds in the daylight, I took fright with only a servant ; so I popped my head into the diningroom, and said, 'We shall meet at the ball, uncle,' which meant, 'Will some one come with us?' So Mr. Katon said, 'Stop, you are not going alone'. So off he came; patent-leather boots and gold-laced trousers. It was an even downpour, the road in puddles. Very soon the light went out, and off ran the servant to get another. We floundered on. At last, seeing a light, we rushed into a miserable vegetable store (shop), where a black woman and some children could give us no help, and to everybody that passed Mr. Katon called out, 'Goldsmith' (the servant). At last a man with a light said, 'Sir, can I be of any use? I will show you your way?' 'Oh, thank you-to Mrs. Higgs.' 'Mrs. Sammy Higgs!' screamed Mailly, so proud of having learned the 'Sammy' from a black boy, when asking her way in the morning. Our unknown preserver guided us there, and remains unknown to this moment. . . ." 


\section{CHAPTER VII.}

I3TH LIGHT DRAGOONS.

I JOINED the I $^{\text {th }}$ Light Dragoons at Hampton Court on 2 Ist January, 1842 . Billy Gore (Lord Harlech) joined at the same time. He came from an infantry regiment, and was much chaffed, as they said he gave the word of command, "Fix bayonets!" My troop was billeted at Colnbrook, and a squadron at Slough.

The regiment was sent from Canterbury to do the escort for the King of Prussia, who had come over to be godfather to the Prince of Wales. The regiment had just returned from India and were a very untidy lot (the horses were all four years old and most of them had sore backs). They had abominable shakos with broad tops and oilskin covers, that looked like black band-boxes; blue jackets with buff facings, red and yellow girdles, blue overalls with two buff stripes, Wellington boots and long hair. The best thing they had was "Sammy stone," a soft green stone which they brought from India, wonderfully good stuff to polish steel. They had marched up from Canterbury.

Our Colonel (Brunton) had been in an infantry regiment in the Peninsula. $\mathrm{He}$ was a fine old soldier, and a most amiable agreeable gentleman; a 
first-rate drill, but no use as a cavalry soldier ; a very bad horseman, and knew little about horses.

The Major, Wathen, came from the $5^{\text {th }}$ Hussars. He had had Lord Cardigan tried by a court-martial and removed from the regiment. Cardigan was afterwards appointed to the IIth Hussars. Mrs. Wathen was a pattern Major's wife, an excellent horsewoman, and very kind to all the boys in the regiment. She was one of the Rothes family.

Digby Hamilton, senior Major.

Jim Sergeaunt, a married chap and a great favourite. He died while in the regiment, so his wife lost all his purchase money. She had four sons, all of whom enlisted in the regiment. One of them was afterwards drill instructor to the Fife Light Horse, but he was not steady. He was a pattern dragoon and a first-rate drill. Another son was many years Regimental Sergeant-major in the I 3 th. He was specially allowed to retain his appointment, although past his time.

"Paddy" Knox, a pattern Irishman, with a black wig.

Charlie Doherty, from I 4 th Light Dragoons, commanded the regiment in the Crimea, but was not present at Balaclava, being on sick list.

Henry Hamilton ("Whisker"), a nice fellow who died of consumption some years afterwards.

Sam Dickson, from the $32 \mathrm{nd}$, a very smart, goodlooking chap; a capital officer and a good sportsman; was afterwards Master of the Limerick Hounds. A capital coachman. 
Tom Bateson, afterwards Sir Thomas, M.P., very good-looking and a charming gentleman.

Hunter Allgood, Nunwick, Northumberland, afterwards M.F.H., Tyndale, a rare good fellow, very witty and full of fun, and a capital horseman. He had a famous little horse by "Dr. Syntax". His gun burst at Norwich and blew his thumb off. $\mathrm{He}$ rode in a steeplechase with one hand.

John Madocks, by good luck, was my Lieutenant, and our ambition was to get the men to look like the gth Lancers.

John Morgan Gwynne-Hughes, from I 4th Light Dragoons, was my Cornet, in height about 6 feet 3 inches. A wonderful musician and a wonderful man to eat. He had a pack of hounds at home at Tregyb Llandilo, which he gave to the regiment, and they became the $13^{\text {th }}$ Light Dragoons' Staghounds.

I wrote from

"ColnBRook, Tuesday, 25th Jamuary, 1842.

"My Dear Mother,--

"I suppose you would like to know my operations since I left you. I had a very prosperous journey by the 'Chevy'. When I got to Eckington, near Derby, who did I see but that everlasting 'Sam Slick' standing with his carpet-bag. I did not speak to him, so I don't know where he went to. I had two very pleasant companions going to OxfordSeaton, a friend of Graham Montgomery's, and Mercer, who, I think, had been at Langhorn's with 
Willie. He and a Miss Calder managed to change portmanteaus at Melrose, much to his disgust as he had to go on without it. At Derby I found an old Derby friend-Mr. Palmer Morewood, who said he had just come to Derby for the ball, and offered me a ticket and a dinner; but the train was just starting, so I could not get my baggage. On Friday morning I drove down to Hampton Court and found three troops there and the Colonel, etc. He is a very nice old fellow, and I liked the whole of them very well. They are the tallest lot of officers I ever saw. In our three troops there is no one under six feet. On Saturday I packed up all my kit, and found Madocks in London in the evening. On Sunday I went to Watford with him and saw the other three troops. Yesterday they marched to Slough; two troops are billeted there and mine here. Madocks and I go to Slough to dinner and sleep here; we are to dine with the Blues to-day and the I I th to-morrow.

"Wednesday.-Yesterday the baby ${ }^{1}$ was christened. Madocks had a ticket for it, so he saw it all; the rest of us got into the quadrangle of the castle. It was a very pretty sight, the Guards, the $72 \mathrm{nd}$ and a guard of honour of the Blues all drawn up in it, and their bands playing by turns. Willy Adam ( 72 nd) gave us a luncheon at his barracks. The banquet in the evening was very fine, but no tickets to be got, so I did not see it. Some of the officers of the Blues put on the band dress and marched in with their band, so they saw all the fun. This morn-

${ }^{1}$ King Edward VII. 
ing there was to be a review of horse artillery in the park, and the 72 nd to have their new colours presented to them. We are just going to ride over to see what is going on. It has been raining cats and dogs all morning. To-morrow I expect the King of Prussia will go to Oxford, and I expect we shall have to go with him. Some people say we shall return to Norwich, and remain there another year. I hope we may. Will you tell Ballingall to send the remains of my money to Cox \& Co. What have you done with Jim? Write to me at Limmer's, as I shall most likely be in town again soon, and I don't know where else we may be sent to. I hope you are all flourishing again and the colds gone.

"Love to all,

"Your affec.

$$
\text { "J. A. T." }
$$

The Blues were quartered at Windsor and were very hospitable to us, and the I Ith Hussars were at Hounslow commanded by Lord Cardigan. They sent us a regimental invitation to dinner. One of them, Cunningham, had a pack of staghounds which he kept at Jim Parson's public-house at Kingston. It was hard frost when we went to dine with them. After dinner we adjourned into some one's room. All sat on the floor and chaffed. About three in the morning it began to rain, and so we all wanted to hunt, but there was a watering parade ordered for the morning, so it was settled we should send a deputation to Cardigan to ask leave. 
Johnny Vivian and I were selected. We knocked at his door and a gruff voice said "Come in". $\mathrm{He}$ was sitting on the side of his bed, with a shawl dressing-gown on and his hair all dishevelled and standing on end. He had not slept a wink, we had made such a row. We stated our request, and he said "Certainly, certainly," so we thanked him and retired. In the morning he put his head cautiously outside the door and said, "Have all those d__ d fellows gone?"

We all assembled at Hampton Wick. I rode "Prisoner" and mounted John Madocks on "Cannibal". The stag was turned out near Maldon in Surrey, and we had a good run of one and a half hour. We were all riding as jealous as demons, and crossed the Maldon River. I got to it first at a very bad place at a bend in the river. I never turned right or left, but went bang at it. In I went ; "Prisoner" just landed his fore-feet on the bank and scrambled out, and on we went.

I 8th February.-Marched from Colnbrook to Watford. Next day to St. Albans, and got a hunt with Harvey Coombe's hounds at Haresfoot, near Berkhampstead. Will Todd, huntsman. A finè pack of hounds, formerly Osbaldeston's. Ran first fox to ground, second beat us, ground foiled by harriers. 22nd March.-Norfolk Hounds met at Hockham, twenty-four or twenty-five miles from Norwich. I sent "Prisoner" on and rode "Viceroy" to the meet. I went to breakfast with Mr. Partridge. They drew many coverts blank. Found in Bradenham Woods at twenty minutes to four. Ran to 



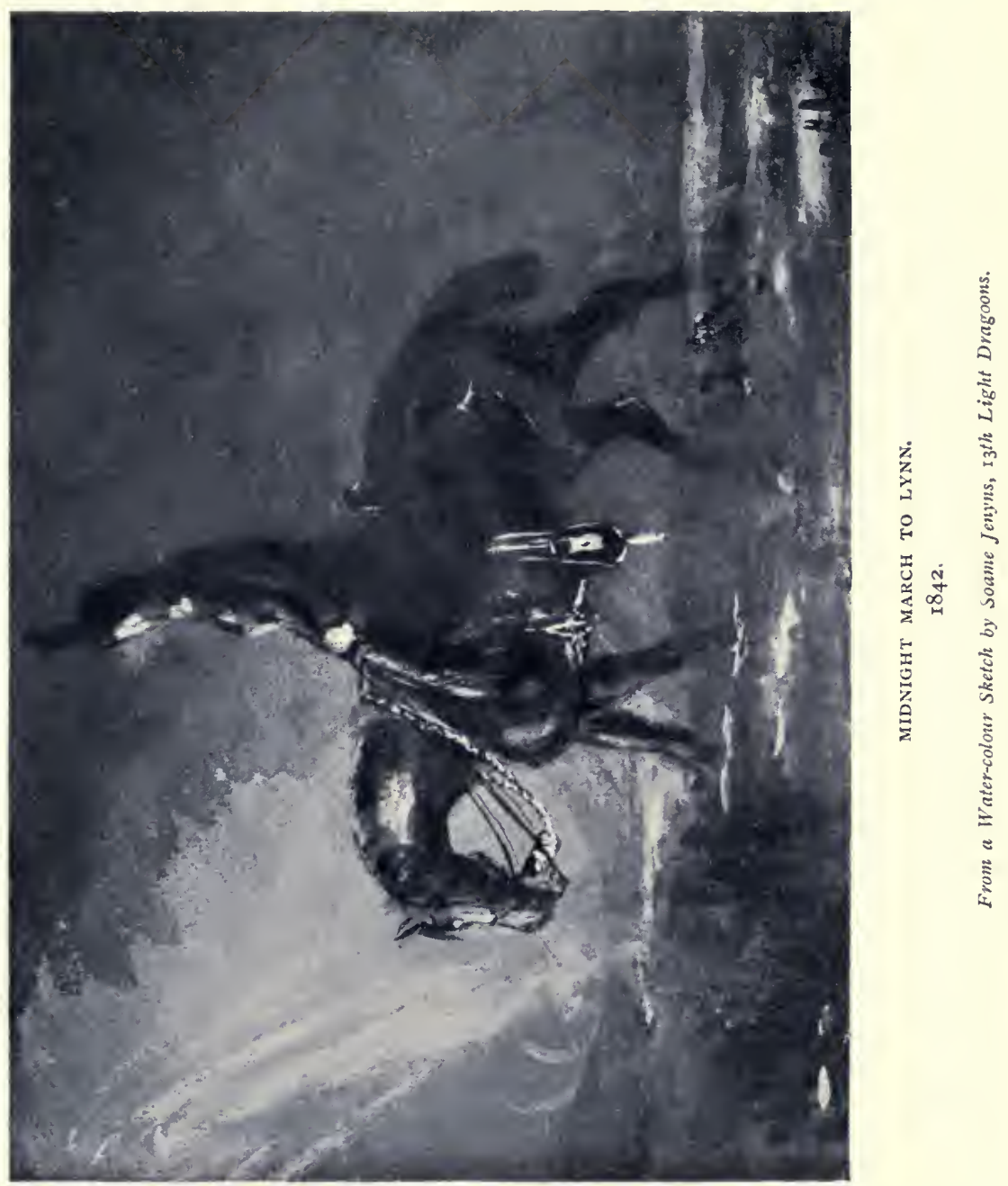


Swaffham Heath, and lost him at 5.I 5, about twentyfive miles from home.

I had told my man to go home if I was not at a certain place at about five o'clock. I got there about twenty minutes late and never could overtake him, as my horse was tired. I got into barracks about ten o'clock, and found all the stables lighted. Asked a trumpeter what was up, and he told me my troop had been ordered to Lynn to quell a riot. I had had nothing to eat and had been wet to the skin twice. My Cornet, John Hughes, was dining out somewhere.

I met Major Wathen at the mess-room door. He said, "I am so glad you have come in-I was just preparing to go myself. Are you fit to go ?" "All right, sir," I said, "as soon as I have had something to eat." I got some bubble and squeak and a bottle of claret.

Luckily I had a fresh horse, "Cannibal". By this time Hughes had come in, so he was started with the troop, and I followed after changing my clothes.

I had forty horses with me, all five-year-olds, and all out of condition. Eight of them tumbled down during the night. It rained part of the time and froze in the morning and was very slippery. Luckily I had been in the habit of driving the Lynn mail, so knew the road, or we never should have got there. It was so dark that we had to feel the figures on the mile stones.

The mail coach met us on the way, and Tom Raynham, the coachman, said, "You'll find they are 
ready for you at Dereham " (a town on the road to Lynn).

We got the horses put into the stables for twenty minutes, and had some coffee and off again. We arrived at Lynn about 10.30. On the way Colonel Oakes, the Chief-Constable (formerly of the Life Guards), overtook us in a waggonette with some policemen.

We formed up in front of the Mayor's house. We had not been there ten minutes when the rioters appeared, eight abreast, arm in arm, right across the street. They came to a corner, saw the troop, all stopped, then marched on, turned down a street and we never saw them again.

Our men were sent to their billets and ordered not to unsaddle their horses. They fed them and lay down on the straw beside them.

I got some breakfast, lay down on the hearthrug with a sofa cushion under my head, and fell fast asleep. I had been out twenty-six hours and ridden over I 26 miles.

Colonel Oakes and his men went and arrested the ringleaders, and we heard no more of the riot. The dock porters had struck and threatened to burn down the Mayor's house.

We were kept there about a month, and had a happy time of it, for we had nothing to do, and Mr. Villebois, the old squire at Marham, allowed us to go there whenever we liked.

One night we had dined there and returned to Lynn in Hughes's gig. When we got into the town 
the cloak round my legs was pulled. I said, "Why did you pull the cloak off me?" He said, "I didn't". Then it happened again just as we got to the inn door. The end of his cloak had got fast on the bolt of the wheel, and they had to back the cart round the market place to undo it.

That summer, Ioth August, I 842, there were great manœuvres in Germany, and any English officers who sent in their names to the War Office were allowed to attend them. Dickson and I applied. I sent two horses, "Viceroy," a white stallion, and a bay mare, as I thought it might be a good chance to sell them; but that did not succeed, as most of the officers with whom we were, were visitors like ourselves. We were treated with the greatest hospitality, billeted and fed, and horses provided for us, and I received rations for my horses.

I had a little stable boy about sixteen years old, Jim Chesnal. I wrote to John Madocks at Ipswich to send him and two horses to Cologne. I told him to send him to London, and "Peg," the one-legged porter at Limmer's, would forward him.

Madocks sent for Jim and said to him, "You are to go to Cologne". "Yes, sir." "Do you know where it is?" "Yes, sir, a little beyond Colchester." $\mathrm{He}$ and his horses were put into a steamer going to Dusseldorf, and when Dickson and I arrived, there he was.

We could not get our horses disembarked for the first review, so we put our saddles on a wheelbarrow and went in our stable jackets to a place where the 
horses were. I got a great big useful beast. The officer in charge could not quite make us out as our dress was so plain, and all the others were in full dress. "Haben sie kein Epauletten?" he said. "Ja wohl, wir sind noch nicht angezogen." From Dusseldorf we went to Cologne, and then to Bonn. The camp was at Eiskirchen, about twelve miles off. Thirty thousand men were under canvas. We had carriages provided to drive to the ground. Troop horses for those who required them. Dinner in the town hall on our return. There were about sixty English officers. The Duke of Cambridge, Lord de Ros, Charles Ibbetson, I I th Hussars, R. Wood, Ioth Hussars, Rodolf de Salés, 8th Hussars, Henry de Bathe, Guards, Sir Henry Bethune, Commander-inChief of the Persian Army, etc. Lots of Dutchmen, capital fellows. Some of the old ones had been quartered in England in the Brunswick Brigade; no Frenchmen.

When we left Bonn I gave Jim some money and told him to get home as soon as he could. When we got to London he was standing at the door of Limmer's Hotel. Dickson and I went on to Ehrenbreitstein. We put up at Weisse Taube, and slept in the same room. Next morning I said, "Shall we go home to-day?" "Yes, the bugs have settled it."

We started to sail down the Rhine and found on board Bill Duff, who was courting. Mrs. — a widow : as soon as he got home he married her; another widow, very pretty, whom Dickson took to 
at once, and Miss - - an old friend of mine when I was quartered at Dorchester. They all got married soon after, so we were a most cheery party.

Bill Duff was a wonderful chap. He had been in the roth Hussars. He was very good-looking, tall, pale and thin, full of mischief of every sort, and although I knew him intimately, I never could make out when he was chaffing or when in earnest. He was most fastidious in his dress and refined in his manners. He knew every prize-fighter in London, and was first-rate with his fists. He also knew many thieves and could "patter flash," i.e., talk their language. I once went with him to "The Rookery" in St. Giles, where they assemble. The company was presided over by a lady who sold watercress. They drank gin punch out of a bucket, which they dipped into with their mugs. They sang songs, danced hornpipes, and when it was all over we were kept back behind the bar till they had all cleared off. If we had got into the crowd they would have cleaned us out.

One night Bill dined with us at Hounslow and started to drive back to London. On the way he quarrelled with his companion and said he would walk. In the morning a greengrocer's tax-cart was seen, with a pair of patent-leather boots sticking out, and Bill Duff in the bottom of the cart.

He was tried and convicted for injuring a policeman. The policeman, I believe, was knocked down and run over by a cab. Bill was not the culprit, but he would not split on his companion. He was in the 
Queen's Bench Prison for, I think, two months. I often went to see him. He wrote the names of all his visitors on the window with a diamond, and for exercise he used to spar with Alex. Reid, the prizefighter.

October, 1842.-At Ipswich, in the autumn, we decided to have a pack of staghounds. All the fellows in the regiment entered into it cordially, and all the gentlemen in the country gave us permission - Sir William Middleton, Mr. Shawe of Kesgrave, Colonel Lloyd Anstruther of Hintlesham, etc. Hughes sent to Wales for his hounds-nine couple; some of them the smooth Welsh sort, with sharp noses and rather light of bone.

Lord Rosslyn was then Master of the Buckhounds. He gave us a couple which were too slow for Her Majesty's pack. Mr. Nunn, Master of Essex and Suffolk, gave us a couple and a half-" Talisman," "Wrangler" and "Faustus". We got two couple from Harry Villebois.

The kennels were at Bramford Mill; Mr. Edwards, the tenant, compounded for $£ 6$ rent for the season. Sam Ritcher was kennel huntsman. $\mathrm{He}$ had been with a pack of harriers - a good keen chap, wages eighteen shillings per week.

I went to London and bought a hind from Herring ; called it "Salt-Fish". Lord Rosslyn gave us another hind. Mr. Morgan, a farmer at Bramford, kept the deer for us, and he had a fallow buck called "Bob". A carpenter named Forsdyke drove the deer cart. Huntsman, J. A. T. ; first whip, John 
Madocks; second whip, John Legrew, veterinary surgeon; secretary, W. Ormesby Gore, now Lord Harlech. The subscription amounted to $£ \mathrm{I} 39$. We wore red coats and caps, and blue bird's-eye neckcloths.

We had some capital horses. I had "Prisoner," an awful hard puller; could go fast and jump a house. I bought him from John Elmore the day the Prince of Wales was born, and gave $£ 200$ for him. "Cannibal," the bay horse, I 6.3 hands-a very savage horse in the stable; lots of action. I rode him as charger; a wonderful timber jumper. One day I rode him down a furrow in a wheat-field. White worsted was put on sticks about four feet high across the field to scare the birds. He insisted on jumping every one of them in spite of all I could do. " John," the brown horse, a capital hunterthe first horse I bought in 1836 when I joined the 9th. I had him eleven years.

Madocks had a capital grey horse named "Creole," that ran in many steeplechases, and a chestnut, "Sir William".

Later in the season Harry Villebois gave us a stag, "Sir Walter Scott". He was very uncertain, sometimes would run, sometimes not. He was very savage, and could defend himself from the hounds. When turned out of the cart, if he saw two or three horsemen together, he went straight at them; and it was very ridiculous seeing them gallop in all directions to avoid him.

We bought another capital stag from Villebois VOL. I. 
for $£_{15}$, "The Sheriff". Unfortunately, one day after a run he ran into a farmyard. A farm man threw a rope round his neck and he fell down. I was close to him and cut the rope, but he was dead. A very little thing will kill them when blown.

We had capital sport. The following letter appeared in the Ipswich paper :-

"On Monday the meet was fixed for Debenham 'Cherry Tree,' and at eleven o'clock a fresh deer from $\mathrm{Mr}$. Villebois was turned out in a meadow of $\mathrm{Mr}$. Norris's. In twenty minutes the hounds were laid on, and one of the finest runs ever seen followed. From Debenham he crossed the road to Winston, from which after a momentary check the hounds ran for forty minutes at the top of their speed. It was indeed racing pace through the parishes of Crowfield, Petaugh, Gosbeck, and Helmingham up to Henley Church. During this severe run through a line of country more heavy and deep than any in the country, Captain Thomson (on 'Prisoner') took a decided lead, followed at a short distance by Mr. Madocks (on 'Sir William'), their horses proving to be in first-rate condition. Captain Dickson, who had been riding in good style, suddenly disappeared, his horse having afterwards to be relieved from his little embarrassment by being dragged by ropes from the species of grave in which he was buried. I also observed Mr. Colthorpe going well on a compact grey steed, and two or three red coats gleaming in the distance. A short check at Henley allowed many to come up, and at the 'Take in the Pond' at Aken- 
ham most of the field arrived. The run was twelve miles from point to point ; time one hour and twenty minutes. The distance must have exceeded fifteen miles."

I 843.-I pswich.- - Had a letter from Mr. Honeywood, Marks Hall, Colchester, saying there was a deer in his woods and we might come to hunt it. 22nd April.-We sent horses and hounds on the night before to Colchester and went ourselves to the Dedham ball. After the ball got into a post-chaise and drove to Marks Hall, arriving at 6 A.M. Went and sat in the kitchen while we sent to rouse the squire. He soon appeared and gave us some breakfast, then out we went. Some few farmers had got notice and turned out, among others Mr. Fisher Hobbs, a good sportsman, a celebrated agriculturist, and famous for his breed of pigs.

The hounds were not used to draw, and could not be induced to go into the cover, and as the leaves had begun to bud and there was a good deal of dew I was wet to the skin. After drawing in vain for a long time I was just beginning to give up hope, when round a corner, down a rack way, a great fine buck almost ran against me. I holloaed and got the hounds away close at him. I forget how long they ran, but more than an hour, and I got a view of him dead-beat. He ran into a ditch. I got there as soon as the hounds, got a pair of couples round his horns, and kept the hounds at bay. I had just done so when I. heard a pack of hounds running hard. I gave some one hold of the deer, cut away with the $7 *$ 
hounds, and had got them into a barn and shut the door when the Essex Foxhounds appeared. There was no one very near them and off we went at the top of the hunt, and when they checked no one knew where we had come from. We then returned for our own hounds and started for home. It was market day in Colchester, and we stopped to refresh. A farmer, Mr. Cookes, came to me and said, "I hear you have caught my deer". I said, "I think he is mine now". We had a little argument on the subject, and agreed to refer it to two gentlemen. I forget who they were, but they decided in my favour, so I sent a cart and got him home.

At the end of the season we were relieved at Ipswich by the Scots Greys. They took over the hounds from us. Lord William Hill was huntsman. Unfortunately, he was galloping a horse in Bramford Park, when his horse swerved against a tree, struck his head and killed him.

I went on leave in March to Leamington, where my mother and sisters were staying. Madocks went there also to his mother.

8th February.-Got out with North Warwickshire, Mr. Hillyar's, at Dunchurch, and Mr. Drake's at Shuckborough. Also with the Warwickshire, Lord Willoughby de Broke, master; Stevens, huntsman; Morris, first whip. I saw "Nimrod" out hunting one day with them.

Went with Lord Worsley, Madocks and Carrington Smith in a phaeton to meet Pytchley Hounds at Welton (my back very bad with rheumatism). 
Smith, the huntsman, not out. Goddard hunting hounds; not much good. Ran to Kelmarsh; rode back to Daventry, twenty miles, and drove seventeen more back to Leamington.

Ist May, 1843.-Marched to Hounslow.

Sir John Halkett of Pitfirrane was a Captain in the navy, and had a pack of staghounds near Portsmouth. His son, Sir Arthur, sent me a copy of a letter from Charles Davis, huntsman to Her Majesty's Staghounds, to Captain Halkett on the subject of hounds breaking away to the deer cart :-

\section{"Ascot Heath, I2th December, 1839.}

"SiR,-

"I am delighted to hear of your good sport, but am grieved at your information respecting the hounds breaking away. I always profess candour, and must therefore give my opinion thus: I really believe there is no cure for your grievance. It probably might have been prevented, the method of which cannot be put on paper, as it consists of a thorough knowledge of the temper, disposition, etc., of each hound, to so great a degree as to know what each intends doing before they put their vice in practice. And at such times speak not harshly, but kindly, and even your countenance must bear the impress of friendship.

"Correction I do not advocate, and it is equally wrong to say I never suffer the whip to be used; but certainly never when you are taking them to the meet, for by causing one hound to cry the others 
would be off 'gadding o'er the plain'. I am sorry to hold out no encouragement, but it is only an opinion after all. Hounds are sagacious beyond belief of many, and man must use his own intellect and learning, too, to deceive them. Therefore you must not try deception with them, but treat them with the greatest confidence, and make them know you are beholden to them, not vice versâ. For instance, yonder is a cluster of people; they (the hounds) know the deer is gone from that spot. You must beg of them to go there quietly, not say you shall do so.

"If you saw me trot up to the spot I must assure you it was an exception to my general way, for I creep as quiet and slow as possible. Yesterday I stood within five yards of where the deer left the cart. I never heard of any pack doing this but this one. Lord Derby's used to fly away in all directions; the Royal Hounds in the old time did so too.

"We did not take our deer last night till past four o'clock-four hours' run, twenty miles from home.

"I have a few pretty little hounds sent home from walk that will not get to our size. They could not, of course, hunt this season, but if you are anxious to have them please let me know, or some other gentleman may step in.

"I shall at all times be pleased to give you any information worth having on the 'Noble Science'.

"I am, Sir,

"Your dutiful servant, "Charles Davis." 
In I844 I was on leave at Kilmany; my mother then lived there. I joined again at Hounslow on I 4 th January. On 15 th February Sam Dickson and I went down to Swindon and put up at the Goddard Arms to hunt with Lord Gifford, then Master of the V.W.H. I had four capital horses- "Prisoner," "Cannibal," "John" and "Discount," a very hard puller, which I bought from Elmore. He had belonged to Sir Francis Grant.

John Calley was then living at Burderop Park. He was a dear friend of mine, and a most amusing and delightful companion. We often stayed at Burderop.

Sir John Ogilvy of Baldovan was staying at Charlton Park. He married Lady Jane Howard. Lord Andover was a great friend of mine. He kept a pack of beagles, and we fraternised over that. His father, old Lord Suffolk, was very kind to me. The first morning when I came down to breakfast an old gentleman, with his grey hair cropped very short, in a green coat and brass buttons, was sitting on the fender toasting a bit of bacon. The large hall in the house had not been finished, and there were amateur frescoes on the plaster of the walls. At dinner time the ladies went into the dining-room, and the men straggled in by chance. The butler was a great character, and had been there all his life. At dinner Lord Suffolk asked for some mustard. The butler looked over his shoulder and pointed at his plate, and said, "Ye got some".

Sir Benjamin Hall kept his horses somewhere 
near, and often went to Charlton, and I used to go down in the train with him.

Gifford was a capital sportsman and a real huntsman, but rather short in his temper. Jack Grant was his first whip. He was afterwards in Fife when Lord Rosslyn was master. Gifford afterwards was Master of the H.H. in Hampshire.

In March the Military Steeplechase took place at Northampton. I took "Cannibal" down and had a hunt with the Pytchley at Cottesbrooke. Hollyoak Goodrick was master; Will Smith, huntsman; Hugh Burns, from Duke of Buccleuch, first whip, and Tom Balls, second. Smith said Hugh was no use in that country, they lost him every day ; he was afterwards with Walker in Fife. Tom Balls was a very nice, clever man, afterwards huntsman to Baron Rothschild's Staghounds. George Payne was to succeed as Master of Pytchley, and they had just bought Mr. Newman's hounds, which, I believe, were the beginning of the present pack.

While I was quartered at Hampton Court I got six couples of beagles from the Rev. P. Honeywood in Essex-beauties! Jim Parsons, a poulterer, who kept a public at Hampton Wick, used to get bagged hares, and there was one hare in the market garden over the bridge which we hunted about once a week. Towards the end of the season the proprietor warned me off, as the boys who ran with us broke the fences. That day I killed the hare, and ended the season.

I 7 th April, 1844.-End of the season. The Queen's Staghounds went to Lyndhurst. Lord 
Rosslyn was master and stayed with Mr. Compton. I went to the hotel. Algood lent me a chestnut horse. A grand, great stag came bounding over the palings, out of a plantation in view of the whole field, then ran over the moor about twelve miles, into some enclosures near the sea, and I thought my time had come, as there were some fences; but the beast turned round, and ran all the way back to Lyndhurst. All the horses were tired; I believe some of them died. The Queen's Hounds never went to hunt in the New Forest again, and the reddeer were all destroyed.

On the I $5^{\text {th }}$ May we marched from Hampton Court to Exeter. My troop went to Trowbridge for a short time, and I got to Exeter on the Ist July.

January, I 845, at Exeter. Martin Howarth was master of the Devon Hounds; Tom Clarke, his whipper-in, and Charles Pike, kennel boy. Howarth lived in the village of Powderham, and was factor to Lord Courtenay. Lady Mary Howarth was Lord Courtenay's cousin. She was afterwards Countess of Rothes. Howarth was keen enough, but not much of a huntsman. He would sit on the top of a hill and view-holloa, though his hounds were a mile away. 


\section{CHAPTER VIII.}

\section{EXETER AND IRELAND.}

When we marched from Hampton Court to Exeter I took the beagles in a dog-cart, with a fish-kettle slung on the axle to boil the feed in.

I was very often at Pines. Stafford Northcote's father and grandfather were both very kind to me. He was not at home, being, I think, at that time private secretary to Mr. Gladstone, and I did not meet him again for nearly forty years, in $187 \mathrm{I}$, when he was shooting at Sir Walter Carew's at Haccombe, and I was staying at Torquay.

John Quicke of Newton, who had been captain of the boats when I was at Eton, and the Rev. Stafford Northcote (uncle of my friend "Tab"), were my keenest beaglers, and Nicholas Cornish, son of a farmer, afterwards huntsman of the Tynedale hounds, commenced his hunting career with my beagles.

There was a cobbler called Gough who used to find hares for us. He would go out to look for them on his pony in the mornings, then put the pony up and follow us on foot, because he said the farmers would not like to see him riding after hounds. $\mathrm{He}$ had an old gun, which had something the matter with it, so he mended it with a bit of leather. It exploded, 
and blew off some of his fingers. Billy Clark, who lived at Chudleigh, also had a pack of beagles, and we used to have joint hunts over Haldon Heath.

Edward Sanders had a farm on Dartmoor named Brympts, where we stayed. William Fortescue took his harriers there, and I took my beagles. The rest of the party were Reid, Rev. Fitz-Taylor (brother of Lady Carew and Lady Willoughby de Broke), the Rev. Henry Fortescue and Logan Downes, one of the best horsemen I ever saw. Most of us slept in the same room.

Tom French, an old sportsman, slept in what he called "the long feathers," the hay-loft. He caught trout for us before breakfast, and found hares during the day. We hunted every day, and one evening attended a wrestling match at Two Bridges, near Dartmoor Prison.

After leaving Brympts, on returning to Exeter, I was driving tandem, and the wheeler tumbled down going down a hill. I was all alone. The first thing to do was to let the beagles out and then unharness the leader and get the wheeler set on his legs. After I had done that I saw something on the ground which looked like a black pancake, and found they had been rolling on my hunting-cap. I do not quite remember, but I think the shafts were broken, for I rode into the town of Ashburton on the leader, followed by the beagles. After a time the beagles did not get on fast enough to please me, so I sold them to a company of bank clerks at Liverpool, and they became the Royal Rock Beagles. I 
bought a pack of harriers, but I forget what became of them.

Felton Hervey was generally my whipper-in. $\mathrm{He}$ joined the $13^{\text {th }}$ about this time. $\mathrm{He}$ is the boy in the picture of the Buckhounds, by Grant, when Chesterfield was master. Sometimes we hunted with the Tiverton Hounds. John Beale was the huntsman; he had no whipper-in. The hounds were taken to the meet in couples, for one day they had met a dead horse, and stopped and ate him up. John Beale was a real workman in a rough way. Once after hunting a fox a long time they ran into a gorse covert. Old John got off his horse and said, "Mr. Hole, do 'ee hold my horse till I pawk un up again". He strode into the covert, blew his horn, and soon got the fox on foot again.

Madocks, Hervey and I often went to Eggesford. The old squire, Newton Fellowes, was very kind to us. Lady Hester was deaf and dumb, but she was charming, and always understood everything that was going on. Two daughters were very nice-one was afterwards Mrs. Seymour Allan, and the other Mrs. Leeke. Young Newton afterwards became Lord Portsmouth. Jack and Mrs. Russell were there, and their son Bury, a boy with a red coat. Mr. Newton Fellowes invited John Madocks, Hervey and me to Eggesford for the Chumleigh Hunt week. Captain Howarth was there with the Devon Hounds. Mr. Fellowes' hounds were very big, oversized drafts from Milton Kennel. Roots was his huntsman, and Jack Dunn whipper-in and second 
horseman, or rather pad groom to Mr. Fellowes. At breakfast there were always mutton pies to take out for lunch, and little napkins to wrap them in. Mr. Fellowes always gave Jack Dunn a bit of his pie. We met Russell's hounds and hunted a fox into a gorse at Ash Rayne. "Nettle," his terrier, spoke in covert, and Russell cheered them to her cry.

A big fox went away at the top of the covert. I said, "That is not the fox we brought here". "Never mind, he will do as well," said Russell, and away we went. This was about twelve o'clock. We crossed a river, and on and on through twelve parishes. Russell was riding a big brown horse, and when he got to a fence, used to say, "Come up, old fellow-one more".

About five o'clock there were only Russell, Howarth, Madocks, Hervey and myself and one or two others with the hounds. My horse, "John," was quite beat. I tied him to a gate-post, and sat on the gate listening to the cry of the hounds, about two fields off. Presently I heard a man, on top of a haystack, holloa, "Tally ho!" I ran across the field and got to them, just as they killed the fox. Our horses walked quietly enough along the road, and we walked after them, and all returned to Eggesford.

That night, after dinner, the conversation turned on the merits of big and little hounds. I said, "Why not let them all run together some day?" Mr. Fellowes approved of the suggestion, and said, "Mr. Russell, you shall hunt them, and my huntsman, 
Roots, will assist you. The present company are invited to return here this day fortnight." Mr. Harris was also there. We all returned to Eggesford for the experiment. In the morning there was sharpish frost and a little snow on the ground. I went with Russell to fetch his hounds, which were at a farmhouse near. I think Mr. Harris's servant was with the hounds. $\mathrm{He}$ had a terrier in his pocket, and I remember Russell saying to him, "Always cheer hounds to cry," and I never forgot it.

When we got to Eggesford, Roots, with twentyfive couple of Mr. Fellowes' hounds, was waiting on the lawn. They were all dog-hounds, about twentyfive inches high. Russell had twenty-five couple, little bitches, mostly black-and-tan. It was a curious sight when the two packs met. The dogs stood on tiptoes with backs up, growling, and looked as big as Jackasses; the little bitches ran round them, and under them, and played about, and it was a long time before they would settle. At last off we went, drew several coverts blank and found about two o'clock. The snow by that time had melted, and made a little moisture on the surface, but there was not much scent. The hounds ran very jealous of each other, and in the small fields looked like a field full of hounds, and you could see by the drooping of their sterns which were carrying the line. Now a big one was first, now a little one, and the best of both sizes cut out the work. At high banks the big dogs had the advantage, at hedges the little ones 
got through first. We hunted the fox about forty minutes and he beat us, and we all returned home well pleased with the performance of both lots.

May, I 845.-Marched from Exeter to Liverpool and embarked for Ireland. Crossed over in The Duchess of Kent. I was very sick. The other squadrons joined us at Dublin. The Major was in command. When I came on parade the morning we were to march, one of the fellows whispered to me, "The Major is as mad as a hatter" (he had been a little queer the year before). $\mathrm{He}$ created awful confusion by making the men dismount and change horses in the street. After a good deal of delay we got them all mounted. I said, "All right now, Sir," and ordered the trumpeter to sound "Walk march".

My troop went to Naas. The headquarter troop with the Major and Lieutenant Madocks went to Cell-bridge. After my troop arrived at Naas I went back to report to Colonel Napier, the AdjutantGeneral. I told him what had happened, and that I had sent to the doctor at Cahir to come immediately.

There happened to be a ball that night in Dublin, 5th June, at Lord Charles Kerr's, so I remained for that, and started next day on the mail to overtake the troops. The up and down mail met at Maryborough, and James Young, the surgeon, arrived there a few minutes before me. When I jumped off the coach, I met the Major's servant at the door as white as a sheet. He said, "Go up, he's cut himself". I ran upstairs, and found him insensible in a bed full of blood, and Dr. Young with his finger on 
the artery in his arm. He says, "Are you a doctor?" I said, "No, but I daresay I can help you". He then looked round and saw who I was. So I put my thumb on the bleeding artery and he began to make preparations for taking it up. Presently another doctor appeared, and they took up the artery, and after a time he showed signs of life and began to recover. Eventually he got quite well, but of course left the regiment. I went on to Limerick, having marched five weeks and one day. The rest were at Cahir. Frank Fosbery was master of the Limerick Hounds. During the winter I went out hunting one day with John Brandling and Goodenough, R.H.A. We drove to covert with my horse in a dog-cart. On the way home the horse shut up. It was pitch dark, and we were sixteen miles from home. Presently we heard the footsteps of a horse, and a chap pulled up and said, "What's the matter?" I said, "Our horse has shut up; will you lend us yours?" He said, "Who are you ?" I said, "We are officers from the barracks in Limerick, and we have been out hunting". Without saying a word he got off and began to take the saddle off his horse, and he said, "We'll get fun when we get him under the car". We shifted the harness on to his horse and put the saddle on my horse.

Goodenough rode my horse, and our benefactor insisted on driving himself. Off we started, and went on quite comfortably. When we got about six miles from Limerick he pulled up and said, "I live up here. Send my horse back to-morrow, and I'll take care of 
yours to-night". It was so dark we never saw his face, and I forget his name. Next morning I sent his horse back and sent him a sov., but he wouldn't take it. Shortly after I was sent to Cahir I began to hunt the i $3^{\text {th }}$ Staghounds.

Lloyd, a subaltern, made the regiment a present of nine couple of foxhounds which he had at his place in Wales.

A chap named Crow was quartered at Cahir with us. He had a horse that pulled too hard for him. I gave him $£ 30$ for him, and christened him "Scarecrow". I sold him to Sandy Stewart, Chamfleury, and tossed up whether he should give me $£ 30$ or $£ 60$. He won the toss. Some time afterwards out hunting he got a fall and hurt his leg just below the knee. However he mounted again, and rode home eleven miles. A little while afterwards, while undressing, his stocking stuck on his heel. He gave it a jerk and broke the shin bone of his leg just below the knee! He then was obliged to have it put in a splint, and had to lay up till it was mended. In the meantime he tossed up $£ 60$ or $£ 120$ for his horse, and again won the toss! The horse was afterwards sold at Tattersall's for $£ 200$.

We had capital fun and hunted all the season. Colonel Laurenson and Harvey whipped-in to mea solitary instance of having a Colonel as a whipperin. This year was the commencement of the potato famine. The only duty we had was to escort the meal carts from Cahir to Clonmel. There was perhaps a mile and a half of carts with wretched ponies VOL. I. 
and a mounted dragoon every 200 yards. It was fourteen miles, and these wretched ponies tired, and occasionally tumbled down and halted the whole line. If any cottages were near, the women used to run out, hold up their petticoats, stick a knife into the sack, get a petticoat full of meal and run away, and, of course, the men could do nothing. It took a whole day to go the distance. The meal was ground Indian corn. In the prison the prisoners were employed breaking stones. The inspector saw one breaking his like powder (Provost Powder). On asking the reason, he said, "Sure, it's to mix with the yellow meal".

I 846. - In spring we marched up to Newbridge, and took our hounds with us. The night we arrived we dined with an infantry mess, and as soon as it was daylight we saddled some horses, and started a chap named Featherstonehaugh with a napkinful of grilled bones and some spirits of wine to run a drag. He started from the back gate of the barracks, galloped about two miles through the mowing grass, which was about up to the horses' knees, and finished on the Curragh, over the white rails in front of the stand. I let the hounds out, and at first could not persuade them to run it; but by shouting and cheering them got up a straggling line, and we arrived on the Curragh as the racehorses were going out to exercise, much to their astonishment.

$15^{\text {th }}$ June.-We marched into Dublin. My troop to Islandbridge Barracks. Sir Edward Blakeney was the General in command, and Colonel Clarke, 



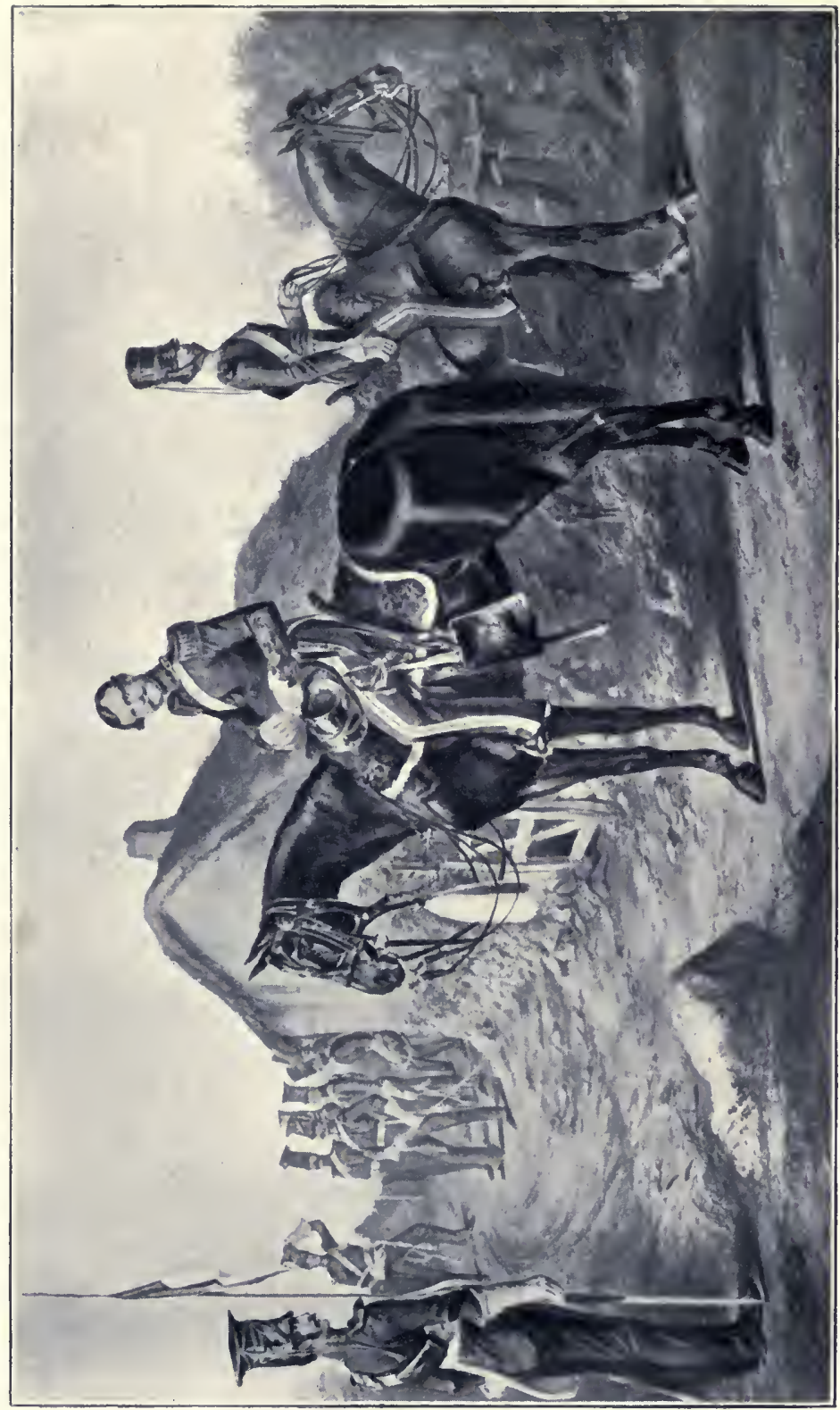

 
Scots Greys, commanding the cavalry brigade. The Scots Greys, the Queen's Bays, and, I think, the $4^{\text {th }}$ Light Dragoons were quartered there at the same time. Lord Bessborough was Lord-Lieutenant in those days.

We hunted with the Garrison Staghounds, Captain Armit their 'master. Felton Harvey, my sub., succeeded him as master some years after.

At that time there were no Meath Hounds, and no coverts in the Meath country. It was hunted by the Ward Union Staghounds. I hunted chiefly with the Kildare Foxhounds. The master was O'Connor Henchy; Jack Glover, huntsman, who had formerly been with Walker in Fife, a slow man; and Philip Tocock was whipper-in.

One of the best fellows was the late Lord Mayo, who was murdered when Governor of India. Old Sir John Kennedy and Lord Clonmel and I were great friends. I went occasionally to the Kilkenny Hounds. Sir John Power was master; Mike Butler, huntsman; and Stephen Goodall, whipper-in. $\mathrm{He}$ afterwards came as kennel huntsman to me in the Atherstone country. Sometimes with the Carlow and Island. Robert Watson was hunting them then, and is doing so still (1903), having hunted the hounds for fifty-seven years.

One day with the Kildare, O'Connor Henchy put his horse at a big bank, but he made a mess of it, and he was falling off when my horse put his head between his leg and the saddle. I put my arm round his waist, and he roared like anything. "All right," 
I said, "I've got ye," and I landed safely on the other side with him in front of me.

I had a beautiful horse called "Dhroleen," I6.2 hands, dark brown with a beautiful head, and carried his tail right up in the air. When I left the regiment I sold him to Captain Burrowes. The year after, I think it was, at Dundalk, he was called out to quell a riot, and then was under the orders of the civil magistrate. The other fellows were sitting at breakfast when they heard a great clatter in the street, and on looking out saw an old woman on her back and a basket of apples rolling about on the pavement, "Dhroleen" on his hind legs pawing the air above her. Major Knox rushed to the window and shouted out, "Good God, Mr. Burrowes, what are you after?" Burrowes saluted, and looking out of the corner of his eye, said, "I have got my orders, sir". 
CHAPTER IX.

ATHERSTONE : FIRST TIME.

WhILE quartered in Royal Barracks, Dublin, I went over to Leamington on the 18 th March, 1847, to attend the Military Steeplechase. I heard that there was a vacancy in the Vale of White Horse, so I went down to Cirencester. The country was hunted by a committee, of which Mr. Raymond Cripps was a member. He lent me a white pony, and I saw a capital hunt. John Dinnicombe was huntsman, and Jim Stacey, a humpbacked man, first whip. As they were satisfied with present arrangements, I made no offer, and returned to Leamington next day. A few days after, while talking to some friends in the street at Leamington, Pat Gordon (afterwards Mr. Gordon Canning) said, "Peter Colvile is giving up the Atherstone. Why don't you take them ?" After considering a moment, I said, "By Jove! I will”. I wrote to Peter Colvile, my old friend (his name is Charles). He replied he thought it would do, and asked me to come over to Atherstone. I telegraphed to Dublin for a horse, and went out hunting on him next day; I then went over and stayed at Atherstone.

A meeting took place soon after, and my offer 
was accepted to hunt the country three days a week on a subscription of $£ 1,500$. I sent in my papers and retired from the regiment, and cut off my moustache. I engaged Will Davies as kennel huntsman; Stephen Shepherd, second whip; Trueman Tuffs, second horseman. Sir R. Sutton took the Quorn the same year I took the Atherstone.

On the 3oth of April, 1847, the sale took place of the Quorn Hounds (Mr. Green of Rolleston's) at Billesdon, and we all went over from Atherstone on George Moore's coach. G. Moore bought a few couple of young hounds, which he gave to the Atherstone, among them a red dog called "Firebrand". After the sale we dined at the "Bell" at Leicester, and had a very jovial party.

A few days after I went over to Melton. There was a match across country between Stirling Crawfurd and Jack Leslie (afterwards Sir John). Leslie's horse, "Charon," looked in the most beautiful condition, and on asking who trained him, I was told his own groom, John Whitehall, and that he was going to leave as Mr. Leslie was not going to hunt next year. I engaged Whitehall on the spot-one of the best grooms I ever saw-and he died in my service in the Pytchley country, I 865.

I got a little house in the village at Witherley, and also engaged Colvile's housekeeper. Old Robert Thurlow, formerly huntsman to Mr. Applewaite, kept the Blue Lion Inn in the village close by, and had capital accommodation for any friends.

At the beginning of the season my two subs., 
John Madocks and Felton Hervey, both retired from the service and came to live with me. The town of Atherstone and the village of Witherley were full of fox-hunters and my old brother officers-Archibald Little, 9th Lancers; Jack Dallas, I Ith Hussars; Sam Hobson, 17th Lancers; W. Wilson ("The Squire"), afterwards my successor as master; W. Owen, Royal Dragoons; Sam Dickson, W. Gore (Lord Harlech) and General Laurenson, I $3^{\text {th }}$ Light Dragoons.

The first hunt took place at five o'clock A.M., $4^{\text {th }}$ September, at Sutton Ambion ; found lots of foxes ; ran till near one o'clock, and caught nothing. Thirtyfive couple of hounds out (too many); much cut up with brambles.

Sutton Ambion belonged to a fine old gentleman with one arm. On going there one day there was a field of wheat standing next the covert, and I hesitated about drawing the wood. He said, "Put in your dogs, sir, put in your dogs," and he set a lot of men to work and cut the field down while we were there. He was presented with a silver cup for his constant and liberal support in preserving foxes.

Rugby country, I $3^{\text {th }}$ November.-Met at Churchover ; rode "Crusader" and "Landseer" ; found at Coton Gorse; had a good gallop and killed at the mill at Lutterworth in the Pytchley country. Lots of people out. Mr. W. Coke, who always rode in white fustian trousers and a red frock coat-a fine old gentleman, "Coke on the pony" in Saddle's song. Sir Richard Sutton came from Quorn. He 
said to C. Newdegate, "I hear that you have got a young man here who can sit still and see the hounds hunt." I was trotting in front of him, turned "Crusader" on to the footpath and jumped a high rail into the field - "And not afraid to get after them," he added. When I had killed the fox he came and congratulated me, and said, "Good-bye". On going to the next covert I was on "Landseer," trotting along the side of a brook, when the stupid beast turned round and jumped at it. It was a very wide place, so we plopped in, and I had to leave him there to be pulled out with ropes. I got on "Crusader" again, and finished the day. Jim Montgomery and Wolfe-Murray were out from Leamington. Jim lost his hat, and when asked where it was pointed over his shoulder, saying, "In yon spinney"-about two miles off.

Atherstone, I 847.-I went to Birmingham with Lady Charlotte Chetwynd to a concert to hear Jenny Lind. I left Birmingham by an early train next morning. At the railway station I met a gentleman who had sat on a chair all night, as there was not a bed to be got in the place. When we arrived at Wilnecote, where I had left my cart, which I bought from Peter Colvile (it had his name painted on it), he said he wanted to go to Merrivale, so I offered to give him a lift. When we got to Mr. Laking's at Hall End a foxhound puppy ran out and followed the cart. I turned round and whipped at it to make it go away. A man on the road kept pointing forward and gesticulating, and I kept looking at 
him as I did not understand what he wanted; presently I went crash into a coal cart, locked both the wheels and brought both concerns to a stand-still. My companion flew away, landed on his elbows and knees, and rather hurt himself. I flew straight ahead, and in my flight caught hold of my pony's collar, and held on till I got my feet on the ground. The pony was very quiet, so we backed the cart and got disconnected. I landed my friend at the gate at Merrivale, and in time for breakfast; and he told Mr. Dugdale that Mr. Colvile had pitched him out of the dog-cart. He had noticed his name was painted on it. I afterwards learned that he was an eminent architect from London, who was building the house at Merrivale. I forget his name.

Colvile bred some hounds by "Yarboro Rallywood," the most famous foxhound at that time. One of them was "Ravisher". The first time I saw him, as a puppy, he was walking about with a chicken in his mouth. $\mathrm{He}$ was walked by old Joe Dester at Bramcote. He turned out to be one of the best hounds I ever saw, and was the sire of many good ones.

Will Davies was a very delicate man, and was very often laid up. He was a most respectable, good servant, and had a good knowledge of hunting. He had been in Shropshire, I think, with Mr. Smith Owen. Stephen Shepherd, second whip, was a capital chap ; quite young, long, thin and very light ; but he was not quite steady. $\mathrm{He}$ came from Mr. Morland, in old Berks country. 
When Davies was laid up I got Robert Thurlow, who had been Mr. Applewaite's huntsman and kept the Blue Lion Inn; but as he did not go to the kennel, and hardly knew the hounds, he was not much use. About this time Lord Southampton bought Lord Shannon's hounds, and brought them from Castle Martyr, co. Cork. Will Smith, the huntsman, who formerly whipped-in to Walker, in Fife, came with them. I went over to Whittlebury and met Tom Lowndes there, who came to mediate between us; and I bought about ten couple. Some of them were very good, especially a badger-pied dog called "Grampus," as crooked as a ram's horn, but he had a capital nose and never tired.

The Atherstone were not a good pack of hounds. In Mr. Applewaite's time the officers quartered at Coventry, and hunting men from Leamington, used to talk of a minute with the "tart," which did not sound as if long runs were the rule.

Among the old Atherstone pack were several which traced back to Mr. Wickstead's Hounds. "Carnage" ran on for eleven seasons. "Active" and "Abigail" were very good. "Active" was the dam of "Ravisher".

Mr.' Colvile bought Mr. Tudway's Hounds. They were coarse and bull-headed, not much drive in them, and did not improve the pack. The condition was not very good; my days were too long for them, and they used to tire before I did.

On the 2oth December, I847, when we met at Stewards Hay, Mr. Martin (in the presence of Mr. 
Cradock and George Moore) told me that on Sir R. Sutton's taking the Quorn country Lord Stamford and Colonel Wildman (his late guardian) had settled that the Ashby and Leicester Road was in future to be the boundary; but that the Quorn were still to have the coverts south of the road, and we were to draw them from the ist November till the Ist March, and that Mr. Wilson ought to have written to say so. I have since been considering whether the limits of a hunting country can be thus changed by the decision of a proprietor. My opinion is it can not. I asked Sir George Chetwynd to consult his brother committeemen, as, of course, it was in their hands, I having made my report officially.

Sir Richard Sutton wrote from

"Quorndon Hall, I8th February, 1848.

"My Dear Sir,-

"As Master of the Quorndon Hunt I consider it my positive duty to protest against your pack drawing the coverts belonging to Lord Stamford north of the Ashby and Leicester Road; and to add that it is contrary to the agreement which was forwarded to me last spring from the committee assembled at Leicester, and on the good faith of which I undertook to hunt this country."

\section{I replied to Sir Richard :-}

"Some time ago when the Atherstone Hounds met at Stewards Hay I was informed by Mr. Martin and Mr. Cradock that Lord Stamford had at your 
request withdrawn the permission to the Atherstone Hounds of drawing his coverts on' the north side of the Leicester and Ashby Road, but that they still might draw those on the south side. I made Lord Howe and the gentlemen of the Atherstone Hunt aware of what Mr. Martin had stated to me. Upon which Lord Howe wrote to Lord Stamford, and last week received a letter from him granting his permission to the Atherstone Hounds to draw his coverts on both sides of the Ashby and Leicester Road on the same conditions as formerly."

A meeting of the Atherstone Hunt Club was held at Witherley on 9th March, I848, there being present : Lord Curzon, chairman; J. A. Thomson, Esq. ; Hon. E. Russell, M.P. ; C. R. Colvile, Esq., M.P. ; Sir J. N. L. Chetwode, Bart. ; Sir W. Dixie, Bart.; Sir Hanson Berney, Bart.; Captain Inge; George Moore, Esq.; Hampden Clement, Esq. ; Richard Jee, Esq.; G. Chetwynd, Esq. ; Kirkby Fenton, Esq. ; Charles Garnett, Esq. ; Henry Garnett, Esq.; Captain Charles Inge; John Floyer, Esq. Having taken into consideration the claim of the Master of the Quorn Hounds to the exclusive right of drawing the coverts, the property of the Earl of Stamford, north of the Ashby and Leicester Road, have agreed that it is their determination to maintain the rights of the Atherstone Hunt, as enjoyed by them for the last thirty years and upwards, and they instruct their committee to reply accordingly. (Carried unanimously.) 
There was proposed by Sir J. N. L. Chetwode, Bart., and seconded by Captain Inge, that the thanks of the meeting be given to John Anstruther Thomson, Esq., for the firm and gentlemanly manner in which he has acted in the matter relating to the disputed question between the Quorn and Atherstone Hunt. (Carried unanimously.)

One evening I was dining at Quorn, and the conversation turned on a purchase which Mr. Greaves, master of Cottesmore, had made of five couple of hounds of the Badsworth pack for $£ 500$. Sir Richard said, "I should like to get five couple of good ones at the same price". I said, "I can tell you where you can get a whole pack for the same money. The Fife Hounds are for sale, and the price

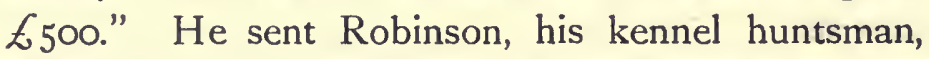
down to Cupar next day; he reported favourably, and Sir Richard bought them. Dick Raby came to Quorn with them about the end of the season, and Sir Richard took them out in the forest. They found directly; there was a good scent, and they ran very hard. Sir Richard said, "Stop them! These Scotch devils will kill a bitch fox." Dick said, "Beg pardon, Sir Richard, it's a dog fox-I saw him over the ride". They ran forty minutes and killed him. The hounds must have thought they were again in Fife among the heather and stone walls. Sir Richard said to Colonel Lowther, "Those Fife Hounds are capital hunters". The Colonel replied, "You'll soon cure them of that".

At that time Atherstone was a charming country to live in. 
Robert Fellowes was at Bitteswell, on the Rugby side, one of the best sportsmen and horsemen in England. He had been at Eton with me, a most knowledgeable man about foxes, and always had a fox in a very small cover.

At Newnham Padox, Lord Denbigh, most kind and hospitable, and the country full of foxes. The young ladies rode well and very keen.

At Coton, Honourable Butler, not a great sportsman, but most hospitable and good supporter.

At Newbold Revel, Sir Grey Skipworth, a grand old gentleman. Unfortunately, when mounting one day, his horse jumped aside and he fell, and he,would never get up again. His son, Sir Thomas, was a good sportsman, and had been in 3 rd Dragoon Guards.

At Arbury, Charlie Newdegate, the most gallant chap across country I ever saw, and a grand preserver of foxes.

At Gopsall, old Lord Howe, the kindest and dearest of friends, always came out cub-hunting with Lady Adelaide (Lady Westmorland) and Lady Emily (Kingscote). They were then girls in the schoolroom; they were capital riders; keen as mustard, and used to watch the rides like cats watching mice. George (Lord Curzon) and Dick had been in Coleridge's house with me at Eton. Fred (the Admiral), Henry (a fine horseman), Ernest and Bill, Essex and Montague, all good sportsmen and capital horsemen. I think Lord Howe let them keep two horses each; if they had more they had to arrange with $\mathrm{Mr}$. 
Savage, the farm bailiff. Gopsall was full of foxes and pheasants too. The Duchess of Beaufort and the Duchess of Abercorn also used to hunt.

George Moore of Appleby was one of my greatest friends, and one of the best judges of hounds. $\mathrm{He}$ had a lovely breed of pointers, and had a sale every year at Tattersall's. He used to get $£ 50$ apiece for them, and then invited all his friends to dine at Greenwich at the "dog dinner".

The quality of his horses was not quite so good, and old Bill Potter, the dealer at Talbot Lane, used to say, "I don't know how Muster Moore can wriggle across country on they tits".

Dick Alken of Hartshill, one of my dearest friends and the most useful man in the country, lived on his own property and had extensive stone pits. He looked after all the foxes during the summer, and never missed a day's cub-hunting.

Hampden Clement, at Snarestone, was a great friend and a steady sportsman.

Old John Moore, at the White House, Appleby, George's uncle, was a capital sportsman.

Captain Inge, at Thorpe, was a real good friend to hunting. He was an autocrat, and loved everything his own way. All the hinges of the gates used to be oiled before hunting. He was never married, and would not allow a child in the parish. He was succeeded by his brother George, the parson, a most eccentric and charming old gentleman, and a real good sportsman. Whenever the hounds appeared at Thorpe baskets full of hot mutton pies appeared, 
and every one that passed was presented with a pie. Charles, the youngest brother, was father of Willie Inge, late M.F.H. and owner of Thorpe. ${ }^{1}$

Lady de Clifford lived at Kirkby Mallory with her son, Edward Russell, and Katey (Mrs. Colville) and Mary (Mrs. Oakeley). Her husband, Mr. W. Russell, had been Master of the Warwickshire Hounds. Edward was an all-round sportsmanhunting, shooting, fishing - he was good at all of it ; and the two ladies are still the best and keenest foxhunters to this day.

I 2 th February, I848.- - Hounds met at Churchover. I came from Edinburgh by the night train to Rugby and got into the train to Atherstone, and met the up train to Rugby. Madocks and Hervey were in it. They shouted to me, "Come in here. We have got your clothes and you can dress in Rugby." I changed into their train, got to Blick's Hotel, had breakfast, and then went to dress.

My servant was an Irishman named Brassel. I said, "Have you got a flannel shirt?" He fumbled in the bag, and said "No". I said, "You stupid idiot, you might as well have left my breeches behind". He took his head out of the bag and said, "Bedad, I have". I said, "Well, go and buy or borrow a pair". He came back with a new pair of drab kersey of the landlord's, with a linen lining and brass buttons on the knees. Luckily, Mr. Blick

${ }^{1}$ Charles Inge was Colonel of the Staffordshire Militia, and quartered at Edinburgh Castle during the Crimean War. He married a daughter of Sir Adam Hay of King's Meadows. 
was a very tall man, and they fitted fairly, but I burst them both across the knees before I got home.

Last day of the season, 5th April.-Killed twenty-one and a half brace foxes, twelve brace to ground.

At the end of my first season Will Davies left. He had very bad health. He took a small farm near Witherley, but did not live very long after. I engaged Stephen Goodall; he was then first whip to Sir John Power with the Kilkenny Hounds. He had commenced in Fife in 1842 under Walker. $\mathrm{He}$ was a tall thin man, a first-rate horseman and good whip. He was afterwards with Mr. Lane Fox, and in the V.W.H. country.

Season 1848-49.-Commenced on the 31st August at Weddington Wood.

Tom Smart, the horse-dealer at Slough, sent me a message that he had a horse to suit me. Mr. Assheton Smith had bought him and returned him. He was a very nervous horse; if you touched his side with your toe in mounting he would jump away. I went to Slough to see him. He was a great fine wellbred horse, and old Smart had sent him out with the Queen's Hounds the day before to make him quiet. He said, "He's hardly fit to show, but get on him and try if you can knock the wind out of him". I got on at the stable-door, which was in a ploughed field, and galloped away. He could gallop well, and was a real good-winded horse, so I bought him for $£ 130$. He could kick me off whenever he liked. I called him "Chloroform".

VOL. 1 . 
One day hounds running across Gopsall Park I was riding "Chloroform". Old Matthew, the keeper, waved a stick as I passed him, when "Chloroform" shied and banged my knee up against a tree. I put arnica on it, and made it as big as two. I was laid up for several days and could not attend the hunt ball. Another day I had him out as second horse. Hounds were just running into their fox, and my first horse, "Landseer," was beginning to tire. Trueman was close by with "Chloroform". I vaulted on to his back and he kicked me over his head so far that I was only stopped by the reins which I held in my hand. I went plop on to my back, struggled on to my tired horse again, and two fields further on hounds ran into their fox. Another time we had killed a fox at Sheet Hedges. I got on him, took a lock of the mane in my left hand, and a hold of the saddle with my right hand. He got his head down, so that I could see nothing except the pommel of the saddle, and shied me off amongst the hounds. Another time he hit a wattle fence with his knees, and threw me a little on to his neck, and he never stopped plunging until he got me down, and afterwards kicked Trueman off also. Little Gilmour bought him at my sale.

1848.-One day Lord Edwin Hill lost his hat, and asked Fenton of Caldecott if he knew where it was. (Fenton used a good deal of liberty with his H's.) He replied, "'Eavens knows!" Hill rode up to Isaac Evans and asked him where it was. "Your hat!-I don't know where it is." Hill went 
back to Fenton and said, "I've asked Isaac Evans, and he doesn't know where it is". "I didn't mean Isaac Evans; I said 'Eavens on 'igh."

When Colvile was master the Atherstone Hounds were to meet at Drayton Manor, and he dined there the night before. Sir Robert Peel (the great Sir R.) said, "I think you will find a fox to-morrow, Mr. Colvile, for I ordered Ballard (the keeper) to put a roook at his den ".

Met at Highcross on 31 st March, 1849 . Killed a fox in the morning and found again near Kirkby. Ran past Newbold, Lindridge, Osbaston, Barlstone, Nailstone and Ibstock, and stopped hounds at seven o'clock. Only Goodall and myself with hounds from Nailstone; Townsend and Captain Rowley. The former was seen at Rugby, and the latter at Atherstone in their red coats on Sunday morning. I didn't get home till ten o'clock.

On Sunday afternoon I was told some one wanted to see me. On going to the garden gate I saw a little man dressed in leather trousers, a green tunic, and a Tyrolese hat with a feather in it. I looked at him for a little while, and he said, "Don't you know me, sir? I'm little John that used to live with Captain Madocks." I said, "And what have you been doing?" "Please, sir, I've been 'unting a pack of 'ounds in 'Ungary, but all the noblemen and gentlemen 'ave been killed; and they were very mad against me, so I 'ad to 'ang all the 'ounds and come away." $\mathrm{He}$ was a very respectable little chap, and had lived with Madocks when we were in the I $3^{\text {th. }}$ 
A little time after he got a place as valet with Mr. Cole, one of the Enniskillen family, and was with him many years.

Very good sport after Christmas. Killed thirtytwo brace, twelve to ground.

There were no hounds in Fife in the season 1848-49. I thought it advisable to go and live at home and re-establish the Fife pack, and therefore sent in my resignation at Atherstone. My horses were sold at Tattersall's on the 16th June-a very good sale.

I had been treated with the greatest kindness by every one in the Atherstone country. On the 4th July I invited many members of the hunt to dine with me at Grillion's Hotel.

Mr. Wilson succeeded me as master. He had hunted with me and lived in Atherstone. $\mathrm{He}$ took a house in the village of Sheepy, engaged Goodall as huntsman and Trueman as first whip. Everything was turned out in first-rate style, second horses, luncheon cases, flasks, hammers, etc., but the season was not a successful one. 


\section{CHAPTER X.}

FIFE : 1849 AND 1850.

The Fife Hounds having been sold to Sir R. Sutton, there were no hounds in Fife in I 848 and I 849 .

$4^{\text {th }}$ July, I 849 . - I bought the Donnington dog pack from Jack Storey and Sir Seymour Blane. They were a good, useful working pack, and cost $£ 200$. I engaged Will Skene as kennel huntsman, who had whipped-in to Walker; Charles Pike, from the Devon, as second whip ; and David Shepherd as feeder, who had been many years with Walker.

I put the kennels in order at Charieton (my father had kept the hounds there in I 803). I bought the pavement in the old kennels at Cupar, which had been taken possession of by the railway, and took it to Charleton. I came home about the 8th July.

On 7 th August I bought two ponies- "Bellows," for $£ 7$ from Porter, the blacksmith at Dykeside, and "Gridiron," from Kitchen, the V.S. at Cupar. On roth October at Clatto Den, first day cub-hunting.

George Moore and Archie Little rode "Bellows" and "Gridiron". Loughborough (Francis) was out, also John Balfour and Lady Theodora Grosvenor. Hot, dry and little scent. Found a brace; ran up to Teasses and back to Clatto and lost him. Found 
in Collinton Hill and ran to ground at Skelpie. I got bogged at Clatto with " Jenny Lind". Will got in a mess with his horse and lamed him badly. I was out eight times before I caught a fox. During the seven days we killed many hares and hunted a good many roe-deer.

First regular day, ist November. Met at Laddedy; ran one hour and ten minutes, and killed in the strip near the west gate of Mount Melville.

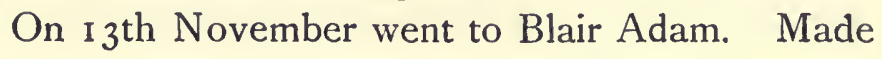
a temporary kennel at Blair Adam Inn. Some of the horses were at the stables at the house and the rest at the inn. My uncle, Sir Charles, and Lady Adam and Mary were there, and I stayed with them.

24th November. - Rumbling Brig; nineteen couple; slight frost, fog and heavy rain; snow on the hills ; capital scent ; found in the moss at Rumbling Brig. Ran all through Blairhill coverts, right up the hill, where the fog was so thick we couldn't see. Found the hounds in the glen at Castle Campbell. The fox jumped up in the middle of them on the rocks. I scrambled down to the waterfall on my feet and found "Wilful " almost drowned in the pool ; pulled her out, tried to jump across, landed all right, but the stone being slippery, tumbled in up to my chin. Luckily I caught hold of a stone, but I had great difficulty in getting out, as it was like a pot, and the current always drew my legs away. When at last I got out the hounds would try to jump after me, and I had to sit on the branch of a tree to guard it. The waterfall made such a row the men couldn't 
hear my horn, and it was so cold I thought I should be frozen. At last Will Skene came to me. I stopped at a farm at Hillfoot and got the water out of my boots; went on to Aldie Wood, found some roe-deer and ran like devils; had great difficulty in stopping them. Wolfe-Murray, Peter Paterson, three Johnstones of Alva, Dempster and Robertson of Tyrie were out. I remained at Blair Adam by myself after the Adams went away. They gave me the key of the cellar, and the old laundrymaid cooked for me. It was a very foggy season; I could never see Benarty Hill in the morning. There was a tree about a hundred yards from the house, and if I could see it I knew it would do to hunt. Wyndham Anstruther stayed with me most of the season and used to ride hirelings from Edinburgh.

3rd December.-Hounds slept at Balbirnie. Met at Auchmoor Bridge next day, and, went home to Charleton after hunting. John Balfour allowed me to send hounds and horses to Balbirnie whenever convenient.

When I first took the Fife Hounds I told my factor, Mr. Ballingall, to ask my tenant, old Mr. Knox, if he would walk a puppy for me. He said, " $\mathrm{Na}$, na, I'll no tak' a beagle; gin a plate is brock in the hoose it's aye the beagle. I'll keep a staig till him, but I'll no tak' a beagle."

Frost lasted from 8th January, I850, till end of month.

Ioth February.-Balbeggie. John Waite was riding my second horse. He stopped to pay the 
toll-gate at Windy Gates, and when he overtook us was as drunk as an owl. I made him get off and left him on the road.

3rd March.-Returned to Blair Adam till end of season.

$5^{\text {th }}$ March, $185^{\circ}$. - Met at Blair Adam; very windy morning; had a fox or two and lots of stags and could do nothing. Went to the Hill of Beath ; found directly; got away close at him and ran into the strips ; turned to the east and crossed the Great North Road, then checked; crossed the Beath Road and hunted him on to Lochgelly; turned to the north and wended on it through a hollow wood; crossed the Orr Water and over some gorsy hills. Here he had waited and we got a view; went as hard as we could split over the grass fields to Lochore House and right over Benarty to Finity; crossed the Leven and ran down the north bank to the east; crossed again to south side about one hundred yards from Scotland Wells Bridge; crossed again to the north opposite Balbedie and set his head for the hill. When opposite Auchmoor he turned towards the covert, but was headed by some men and turned again towards the hill. Here we had a long check, being obliged to go round by Auchmoor Bridge. "Benefit" made a capital hit along the road, and we got the line at the Knock of Arnot and hunted it inch by inch up to a hollow wood at back of Strathendry. Here six couple got on a fresh fox and went away up the Lomond. The body hung to the hunted fox, ran into the round wood behind Strathendry and 
down the strip behind the house. Here while I was opening the gate he jumped up in view. "Edgar" met him in a gap in the wall and caught him at twenty-five minutes to six. "Towney" Oswald, Young, Horsburgh and Cunningham were all that came to the end. The latter, on a hard pulling mare, got an awful fall at Lochore and stood on his head for a minute. Distance, point to point, about eleven miles; the best run I have seen in Fife.

7th.-Milnathort. "Tyrant" cut his legs at Balmuto, and died a few days after. He was a beautiful horse. The Duchess of Athol bought him for a carriage-horse, but he was a bad kicker, so sold him to George Condie in Perth. I bought him from him. He kicked so bad in the stable, that I engaged the man who looked after him.

22nd March.-Damhead. Drew Glenearn blank ; found a stag in Silly Whinny, and ran down to Invermay before I could stop them. Found a brace of foxes and ran fast down the valley, past Dunning, and went to ground in a drain at Kelty Castle. George Moore was out, having come to stay with me at Blair Adam. He brought a horse with him, "Rector," which had belonged to the Rev. Reginald Chandos Pole. He made me a present of him. He was scrambling over a rocky place muttering to himself, "It is too rough a job, it is too rough a job". The drain was half full of water and the fox was drowned. Lord Rollo, his brother "Hon. John," and Colonel Richardson came out on foot. They 
were just going to dinner and gave us some veal cutlets ; horses got some gruel. We did not get back to Blair Adam till I0.30.

Going through Kinross a cart drove up against "Woodman". The shaft hit him on the side and he died a few days afterwards. He was a real good little horse, and carried me capitally with the Garrison Staghounds when quartered in Ireland. On Ist April I took four couple of hounds into the Falkland Woods to hunt roe-deer. Mr. Balfour and party came with guns and killed nine in a very short time. ${ }^{1}$

About the end of the season George Moore asked me to return to Atherstone, and guaranteed me $£ 2,200$ per annum.

This season Sir George Houston and Sir Hugh Campbell hunted Berwickshire. Ben Morgan, from Sir Richard Sutton, was their huntsman. They had got several of the Fife hounds from Sir Richard, and let me have some. One day two couple were left out on the Lomond; one hound went to Balbirnie, where they slept the night before; one to Charleton, and "Edgar" went twenty miles to Torry kennels. He had been both in Leicestershire and Berwickshire since he left there. The country was full of roe-deer and hares. Hounds very unsteady and the men not much good. There were only four foxes in the east of Fife; the best of them a lame dog-fox in Kinglassie Wood. He never ran 100 yards straight, and could run for a week-a rare fox to make young hounds work. I often hunted him. One day I got

1 I don't think there are nine roe-deer in Fife at this time (IgO2). 
a view at him in the open at Airdrie, and ran into him before he could get home.

The best farmer sportsmen were-Andrew Gullane of Drumfin; he knew all about it and was a real sportsman. George Tod of Lochrin, a capital keen man. Robertson of Tyrie, on the hills behind Milnathort, Dempster of Touchie, and Cunningham of Dallachy. Morgan at Saline Den was a capital fox preserver ; he did not ride, but said, "I am a keen sportsman-I aye tak the hill tap".

Will Skene came from Turriff-Lord Kintore's - a clean respectable man, but slow with hounds. He went to Atherstone with me, then returned to Fife, then to Forfarshire when Colonel Maule was master, and to East Lothian under Major Fletcher, and died there.

Charles Pike came from Devonshire. He was a fair whip, but an ill-conditioned fellow. I sent him away in the middle of the season and put Dick Smith on as second whip. He had been riding my second horse.

Pike afterwards became huntsman to Lord Hastings when Master of the Quorn Hounds, a place which he never was fit for. When he gave up, Colonel Barlow, who managed for Lord Hastings, asked me and Mr. Clowes to go to Quorn and look over the hounds. All the dog hounds' had kennel lameness except four couple.

Colonel Lowther meeting Pike in Leicester one day said, "Well, Pike, what are you doing?" $\mathrm{He}$ answered, "I've got the sack. Marquis has taken 
to drink. 'Hermit' has won the Derby, and we are all going to hell together."

Hunting days, $5^{\text {I }}$ (first day, 8th October).

Foxes killed, I 5 .

Run to ground, I I.

Blank days, 5 .

Stopped by frost, 8th January to Ist February.

Last day, I 5 th April. 
CHAPTER XI.

ATHERSTONE: SECOND TIME, 1850.

I ATtended the hunt meeting at Atherstone on I 8th April, and they were all very willing that I should return. But I said, "Where am I to live?" Mr. Bracebridge touched me on the arm and went to the window. I followed him, and he said, "I will lend you my house". Atherstone Hall was a capital house, most convenient, and about a mile from the kennels. One side of the church was in the garden. He said, "They are repairing the church, and if you will give a donation towards the repairs I will lend you the house". I willingly agreed, and gave a cheque for $£$ roo towards the repairs.

$\mathrm{Mr}$. and Mrs. Bracebridge were going abroad for the winter. When the Crimean War broke out they went out with Miss Nightingale and took care of her.

Mr. Bracebridge was a most eccentric man. $\mathrm{He}$ used to ride about on a grey Arab horse, dressed in loose white trousers, a broad-brimmed straw hat and a red umbrella. He bought Mount Hymettus in Greece, famous for honey, and the honey was used in making blacking in England. He was very clever and well-informed. 
Mrs. Bracebridge was a charming woman and great artist. Her portfolios of drawings of all the foreign towns where she had been were quite beautiful.

"The HaLl,

"Atherstone, 28th February, 1850.

"Dear Thomson,-

"If you have time to ride over and sleep. here we shall be happy to see you.

"I wish to put the house affair in the simplest terms.

"I shall be happy to lend you this house from Ist of November till the ist of April. Probably a week longer would make no difference. You to agree to take our two housemaids-good servants, the upper one has been here many years. You to pay milk and potatoes-nothing else; you to have whatever is in the garden; and my gardener to keep up the grounds. You to have saddle-room and ten stalls, thirteen if you want them. My coachman lives at the lodge, and would with his boy take care of my four horses left out of writ. He can have a separate harness-room, and in no way interfere. $\mathrm{He}$ is a good, quiet man. I, of course, retain rick-yard and farm premises. You to have the small wine cellar, and another I can arrange for. You can use the ale there will be, and have the same quantity brewed, or you can buy. My butler remains in the town (he is married and settled there) in his own house. I should want access to my library and cellar for books and 
wine occasionally, if we should not be able to go to Italy.

$$
\begin{aligned}
& \text { "Yours truly, } \\
& \text { "C. BRACEBRIDGE. }
\end{aligned}
$$

"P.S. - I to pay taxes and poor rates as' if I lived here. My butler could brew for me here in October.

"I can say nothing of next year. We should leave china, and perhaps you would bring the silver plate."

My mother and sisters came and lived with me at Atherstone. The I $3^{\text {th }}$ Light Dragoons were quartered at Coventry, and Jenyns and Goad lived with me a great part of the season. Jenyns suffered much from asthma, and often sat up all night propped up with pillows, but he always came up to time in the morning. Goad was rather bald on the top of his head, and had his head shaved except a ring just about his ears, so he never could take his hunting cap off during the day.

I took the hounds which I had in Fife, and the Atherstone Hounds were sold at Tattersall's, and I bought about half of them. George Moore also made me a present of twenty couple from Sir R. Sutton's, many of which were Fife hounds, which he had purchased two years previously when the Fife Hounds were given up and Mr. Whyte-Melville ceased to be master, and John Walker went as huntsman to Sir Watkin Wynn.

George Moore wrote :- 


\section{"Carlton Club, \\ "B4 Albany, igth April, 1850 .}

"I think the head groom might do very well with $£ 70$ a year and his house. The second horseman should find his own clothes at seventeen shillings a week-no tight boots wanted. Lord Henry Bentinck's second horsemen found their own clothes, I am sure, from what I saw last week-no tops, black boots, greasy cords and coat-no sandwich cases and sherry. bottles, shoe cases, hammers, hatchets, and the devil knows what. Should we raise upwards of $£ 2,200$ per annum, I think it should go to you. Of course all money subscribed to the Hounds directly or indirectly must be paid to the guarantees. If you come the hounds are to be sold at Tattersall's same day as Wilson's horses-6th of June, I believe. I am to lot them for the other owners. I saw little Hervey and Dickson last night at Pratt's ; both very glad; and I told Hervey to hunt instead of racing. Please drop me a line to Appleby as soon as you can. Colvile met Tom Arnold in the street, and when he told him there was a probability of your coming back he threw his hat up, to the no small amazement of the inhabitants of the metropolis. I return home tomorrow.

"Enclosed I send you the guarantee in print. I have the original, and shall deposit it at the bank tomorrow on my way home.

"The Warwickshire dispute is that they want Hampton Coppice, Chelmsley Wood, York Wood, etc. These, I believe, belong to them-no great 
loss. They also want Packington, but that belongs to A. H."

George Moore wrote again :-

" Appleby Hall, 25th April, 1850.

"I have just returned from Birmingham, and I hoped to have met you there. I had a room all ready for you. I told all the people you were coming to hunt the country, and I shall guarantee you more money if you want it from prices, etc. But come and talk it over and you shall not complain, and I will make it agreeable. Thus writing, we cannot get on.

"I saw Madocks; he was going home with Chetwynd; he did not sell a horse. The Warwickshire, the Pytchley and Joe Leedham want hounds. Joe Leedham says they have not got a good young one at Hoarcross. I must lot the hounds next week, so you must come before that.

"You must come, and for five years."

I engaged George Cross as kennel huntsman. His father was an Englishman, and farm-bailiff to Captain Barclay of Ury. Cross was educated for a veterinary surgeon, and at one time was an assistant to Professor Dick in Edinburgh. He had a stable at Monifief, and trained race-horses, but finding that didn't pay, and being devoted to hunting, he became whipper-in to Walker with the Fife Hounds. He then became huntsman to the Bedale Hounds under Mr. Millbank. I think he remained there seven VOL. I. 
seasons, and then came to me at Atherstone as kennel huntsman.

He was a good kennel huntsman and scientific breeder of hounds. In the field he hunted a fox steadily. He was only a middling horseman-not very smart in appearance, and a good deal of " James Pig" about him in his sayings and doings. He spoke Scotch. When engaging him I said, "Well, Cross, what about wages?" He says, "I dinna care muckle for wages, but gi'e me a bellyful o' hunting !" His wages were $£$ roo a year, house, garden and clothes, and no perquisites. $\mathrm{He}$ was a capital servant, and an honest, respectable man, but he was unfortunate in his selection of a wife. She was a very handsome, well-educated woman, but addicted to drink, and didn't pay proper attention to him. On coming home from hunting and asking for some dinner, she would say, "There's some nice milk, bread and jelly for you".

I brought Will Skene as second whip, who had been with me in Fife, and Jim McBride as second horseman. He afterwards became huntsman to the Quorn, and to Mr. Reginald Corbet in Cheshire, and died in his service.

Atherstone Hunt Ball took place on the 18th December, 1850. Lady patronesses: The Countess Howe, Honourable Mrs. Colvile, Lady Hartopp, Lady Dixon, Mrs. Dugdale, Mrs. Wollaston, Mrs. Anstruther Thomson. We had a capital party at Atherstone Hall. Whyte-Melville and daughter, afterwards Mrs. Wolfe-Murray, Hugo Meynell, my 
uncle, Sir Charles Adam, Willy and Mary Adam (afterwards Mrs. Antrobus), George Bagot, Mr. Sanderson and Miss Sanderson.

It was a capital ball, but towards the finish the people at the end of the room began to sneeze, and by degrees every one began to sneeze in succession. I was standing near the door. Lord Howe came to me and said, "What can it be?" and began to sneeze and could not finish the sentence. We sent away all the paraffin lamps, opened the windows, and it got a little better, but some people had to go home. No one could guess the cause, but some days after, the father of a boy confided to Sir George Chetwynd and myself that his son, after dressing at the Red Lion Inn, had put some cayenne pepper in his pocket and sprinkled it in the ball-room.

On 3oth December, 1850, I went to the Derby ball, where I met my future wife, Miss Hamilton Gray, and her mother. They had come from Radbourne with the Chandos Pole party. After the ball I went to stay at Radbourne, where Mr. Hamilton Gray was also staying.

Ist January, i 851.-Left Radbourne. Went by train to meet the hounds at Shuttington Bridge.

23rd March.-Went to Leicester on Sunday afternoon. William Clowes lent me a horse to ride over to Quorn to meet Lord Rosslyn and Percy Williams at Sir Richard Sutton's.

24th March.-Barron-in-the-Beans. Good run; killed a fox in Grosby Village; one hour forty-seven minutes. 
25th March.-Went by train to Chesterfield, and went to meet the Rufford Hounds at Hardwicke. Percy Williams mounted me. After hunting, drove to Derby from Mansfield; from Derby trained to Tamworth, and stayed the night at Dr. Geldhart's at Netherseale.

Dr. Geldhart was left some property when he was fifty. Till then he had never been out hunting, but thought he would like to do so. He went to Mr. Tattersall and requested him to provide him with two good horses that knew their business, as he knew nothing about it. He got two beautiful horses, and then went to Jackson's "Hunting Grounds," and took lessons in jumping. At the beginning of the season he stayed at the hotel at Ashby-de-la-Zouch, and hunted with the Atherstone Hounds. He enjoyed it so much that he took Netherseale House, and hunted from there for several seasons.

Wednesday, 26th March.-Cricket's Inn. Rode "Outlaw" all day; got a fall; had a bad sore throat, and it hurt me to blow the horn.

27th March.-At the end of this season I went to Lyndhurst for a sale of Mr. Drax's Hounds. In passing through London I went to look at the building of the great Exhibition. I had an awful bad pain in my chest all morning. On getting to Lyndhurst I went to stay with Lindsay Shedden, Master of the New Forest Hounds. While putting on my boots to go down to dinner my mouth got full of blood, and I knew what had happened-I had broken 
a blood-vessel. I rang the bell, and lay down on the bed with my head on the edge of the dressing-table, and I never moved it for twenty-four hours.' Mr. Shedden came up and sent for the doctor, who lived close by. He was a capital good chap. They kept giving me mouthfuls of iced water and lead pills, and after a time bleeding ceased. My throat was full of coagulated blood, so I roared like a horse. This continued for several days. The doctor's assistant was in the next room day and night. When he heard me cough he rushed in and found I had spit out the clot of blood, and there was no fresh return of the bleeding.

I remained at Lyndhurst till the 22nd of April. I was awfully weak, but had no return of hemorrhage. I went up to London to see Drs. Watson and Cutler. They said I was to go abroad for the winter.

During the summer I stayed some time with my uncle, Sir Frederick Adam, at Richmond Park.

I also went to Bolsover, to Bodelwyddan, Sir John Williams'; and to Newcastle, in Ireland, Mr. King-Harman's, brother-in-law to Mrs. Hamilton Gray, who was staying there with her daughter, and we all went to Ballinasloe Fair.

Will Skene left at the end of the season, and while I was laid up at Lyndhurst Tom Clarke came to see me, as he wanted a situation as first whip. $\mathrm{He}$ was just leaving Mr. Villebois in the Craven country. I had known him for some years, as he was whipper-in to Captain Howarth, Master of the Devon Hounds. 
I engaged Clarke, and he went down to Atherstone and commenced his duties. A short time afterwards I received a letter from Mr. Head Best, who was on the committee of the Craven Hounds, saying that Mr. Villebois had died, and that Ben Foote, his old huntsman, had sent in his resignation. They had just engaged Will Mawe from the Cottesmore as first whip. They asked me to allow Clarke to return to their country as huntsman, as he knew the country, and that Mawe would exchange places. I knew Mawe well from having hunted with the Cottesmore when he was in Mr. Greaves' service, and as he was a good man I agreed to the arrangement, as I thought it not right to stand in the way of any man getting a huntsman's place.

Tom Clarke eventually became huntsman to Mr. Morrel, in the Berkshire country, and afterwards for many years to the Duke of Beaufort.

Mr. Best wrote :-

"The difficulty in which the Craven Hunt are placed in consequence of the death of our late excellent Master, Mr. Villebois, must plead my apology for the liberty I am taking in addressing you.

"The case is briefly this: Our old huntsman has resigned his situation, and our first whip came to us only a few weeks since, consequently perfectly ignorant of both hounds and country. In the dilemma I have been asked to take the management. Now, could you, without putting yourself to any very great inconvenience, spare Clarke to us as huntsman, pro- 
vided our whip, Mawe, would take his place with you? He came to us with a good five years' character as whip from Mr. Greaves of the Cottesmore Hounds. Of course, I need hardly say that I have not spoken a word to Mawe on the subject, nor have I seen or heard a word of Clarke since he left this country."

I replied :-

"It is very inconvenient indeed for me to part with Clarke, as he has just become acquainted with the hounds and country. But at the same time, I think it is hardly fair to prevent a man with a family from getting a better situation, and to spoil the sport of another country by keeping him, though by letting him go I am losing the assistance of a man I can ill spare, and thereby risking the sport of my own country.

"I know Will Mawe, and if I had not engaged Clarke I would have taken him, and if he is willing to take my situation I will make no objection to Clarke going to you. Clarke's wages are $£ 75$ per annum, one suit of clothes, and no extras or perquisites of any sort. If Mawe is satisfied with that, well and good, but if he requires more I think you ought to make up the difference, and pay all his expenses, etc.

"I have told Clarke that I received your letter, and he is anxious to have the situation, so if Mawe consents the sooner the change takes place the better. Mawe can take Clarke's house off his hands, but all 
those arrangements can be made between themselves.

"I must have Mawe at work here before I part with Clarke, so as not to interrupt the work of my young hounds."

In the beginning of November. I went to Atherstone for a few days to make arrangements. There was a hard frost and a fall of snow in the first week in November.

Lord Curzon agreed to act as field-master in my absence abroad and to take charge of the hounds; and Dick Alken undertook to provide forage, etc. I went over to Gopsall to say "good-bye," and Lady Howe said, "Come back in your red coat".

Before going to Rome I was made a deputylieutenant, Admiral Wemyss being then Lord-lieutenant for the county of Fife.

On the 6th November I started from London with my two sisters, Clementina and Jean, a French maid, an Irish valet, an Italian courier named Petrolini, and a big dog called "Major". When we got to Florence Petrolini came to me and said, "I find English cutch-mail cutch". I bought the coach for forty "naps," hired four Vetturino horses, and posted all the way to Rome.

The coach was very useful at Rome. We used to get four hirelings and drive to all the places in the neighbourhood. Martin de Winton-Corry (Spicey Bill) and his wife, and George Holland and his wife (she was sister of Lord Gifford) were gener- 
ally our companions. "Spicey," though a little light man, was a capital coachman.

Holland and his wife went with me to Naples. We got four beautiful black horses and drove all the way. We went to Amalfi, Paestum and other interesting places.

When we started to go home we got Guiseppe Balducci and four horses, and drove to Marseilles. I then gave the coach to Petrolini and went home up the Rhône and by train.

The next season "Spicey" again went abroad. He bought the coach from Petrolini, picked up four useful horses and drove all the way to Rome. My mother and sisters were also going there. Within a few miles of Rome their carriage broke down, and they were sitting by the side of the road when up drove "Spicey" with the old coach and took them into Rome.

In the spring of $185^{2}$ a dinner took place in Tamworth attended by Protectionist farmers. The mob assaulted them and pelted them, and Sir Robert Peel wrote a letter to the Times approving of their conduct.

At the beginning of the season Mr. Dester warned Sir Robert off his land at Seckington, saying that he would allow no one to come there who encouraged the mob at Tamworth to ill-treat the farmers. Sir Robert replied, "If you were a gentleman I would horsewhip you". Mr. Dester replied, "Two can play at that," and insisted on Sir Robert getting off his land. 
The following advertisement appeared soon after :-

"To be sold by auction, by Messrs. Tattersall and Son, at Hyde Park Corner, on Monday, 15th December, I85I, the entive stud of Sir Robert Peel, Bart., who is declining hunting with the Atherstone Hounds in consequence of the unsportsmanlike conduct and political animosity even in the huntingfield of certain Protectionist farmers. They consist of seven superior hunters and two capital hacks."

Mr. Dester to Sir R. Peel :-

"SIR,-

"I think it well to state directly to yourself in reference to what took place in the hunting-field on the 12th November, that my conduct on that occasion was not dictated by political feelings. I disavowed any such motive at the time, and have repeated the same thing on all occasions. I was influenced to act as I did by a strong persuasion that in your letter to your constituents at Tamworth you intended to apply most offensive expressions to all who attended the dinner on the 28th of May. Your language appeared to be directed against all there present without exception or limitation, Mr. Young being only the chief object of attack; and in the absence of all explanation from yourself, you cannot be surprised that such was and is the universal impression. Under this persuasion I still feel that the retaliation does not exceed the provocation. In order, however, to clear myself from even the 
most remote suspicion of introducing political considerations into the hunting-field, I hereby beg leave to recall my act on that occasion, and I can only say on behalf of myself and brother farmers, that so far as simple politics are concerned, we are as glad to see you or any other Free Trader on our land as a Protectionist.

$$
\begin{aligned}
& \text { "I am, Sir, } \\
& \text { "Your obedient servant, } \\
& \text { " William Dester. }
\end{aligned}
$$

"Secrington, 6th December, I851."

I was truly glad that I was absent when this altercation took place. Had I been present I should have decided against Mr. Dester, for he was wrong to bring into the hunting-field any matter arising from a political dinner.

I returned from Rome in May, I 852, and went to Bolsover, then to Cheltenham in June, where the Hamilton Grays were staying, and then to Avening to visit the Cholmeleys (she was Mrs. Hamilton Gray's sister).

I852. - On 25th August I was married at Bolsover to Maria Agnes Robina, only daughter of the Rev. John Hamilton Gray of Carntyne, Lanarkshire, Rector of Bolsover and Scarcliffe, and Rural Dean of Chesterfield. Mrs. Hamilton Gray was sister to James Johnstone of Alva. We went to Edinburgh and home to Charleton next day, and remained there for the rest of the summer.

We went to Atherstone at the end of September 
and lived in a little house on "the Watling Street" in Witherley village, and commenced hunting on the Ist of October, 1852. Cross was huntsman; Will Mawe, first whip; Tom Parker, second whip. Season ended 4th April.

On $4^{\text {th }}$ June, 1853 , my eldest son was born in Edinburgh, and christened John St. Clair. His godfathers were James Lord Rosslyn and John Madocks, I $3^{\text {th }}$ Light Dragoons.

I got possession of Mancetter Manor House in the autumn of 1853 .

I 853.-We began on the 12th September at Gopsall; Cross huntsman, Will Maude first, and Jim Maiden second whips. $\mathrm{He}$ was a son of old Joe Maiden, the Cheshire huntsman, who tumbled into the copper and injured his leg so badly that he had it amputated. For many years he was kennel huntsman in North Staffordshire, and rode with a wooden leg.

One day hunting I was wet through, and when I got to Arbury, Charles Newdegate asked me if I would stay to dinner, and he would send for my clothes. So I had a cup of tea, went to bed and fell asleep. When I awoke I thought it was next morning, and he was in my room dressed for dinner. $\mathrm{He}$ said, "All the people have come to dinner, but your clothes haven't come". Among those present were Lord Cardigan, Lord Willoughby de Broke, Sir Theophilus Biddulph, etc. He said, "Couldn't you wear my clothes?" I managed his shirt, waistcoat and coat well enough, but he always wore his trousers 
very tight, and I couldn't get into them. His valet, a tall pompous man with a powdered head, said, "If you please, sir, Sir Theophilus Biddulph is a very tall gentleman, perhaps his trousers would fit you." I said, "I don't know Sir Theophilus Biddulph, but I shall be very glad to wear his trousers". The valet went downstairs into the drawing-room where fifteen people were assembled for dinner. $\mathrm{Mr}$. Newdegate was sitting by the fire talking to a lady. The servant went up to him and said, "Could I speak to you, if you please, sir?" Newdegate took no notice, on which he repeated it. "Well, George, what is it? Out with it!" He stood to attention, and said in a loud voice, "If you please, sir, Captain Thomson says if he had Sir Theophilus Biddulph's trousers he could come down to dinner," which was received by the assembled company with much mirth. The trousers were brought to me, and I got into them, but Theophilus being very stout, they were rather large round the waist. With the help of a packing needle and some twine we took up some reefs behind, and I was going down to dinner, when, luckily, I met my own servant on the stairs with my own garments. I quickly changed and ran down. They were all prepared to greet me with jeers, but they found me properly clothed and in my right mind.

In 1854 I thought that a change might be desirable, and I had always a fancy for the Vale of White Horse.

I 8th February.-Harry Villebois having decided 
to give up V.W.H., I went down to Cirencester. He was very anxious that I should succeed him, and offered to lend me his house and subscribe $£$ ioo. Raymond Barker was very kind, and did much to smooth the way for me. Henley Greaves was also there, who was nibbling for the country, but they were not keen on him. It ended by Lord Gifford again taking the country.

I got all the information I could and considered all the pros and cons. Before going to bed I wrote two letters, one consenting, the other declining; next morning I sent the one declining, as I thought it was wiser to remain at Atherstone, and went out hunting.

"Twit" Lyon and Greatorex ("The Badger") were staying with Villebois.

Lord Portsmouth bought Villebois' Hounds. Morris was hunting the hounds and old Joe Thomson whipping-in. I think Kit Atkinson was Villebois' huntsman, and that he died in his service.

At a meeting of the Atherstone Hunt on I $3^{\text {th }}$ February, I 855, Charles N. Newdegate, Chairman, I stated my intention to give up the management of the Atherstone Hounds at the end of the season. The meeting expressed "their sincere regret that Mr. Thomson is no longer to hunt the country, and beg to convey to him their best thanks for the sportsmanlike and highly satisfactory manner in which he has hunted the country for seven seasons".

At a meeting on 29th March, I855, Lord Curzon, Chairman, the following letter was received from Mr. Selby Lowndes :- 
"I will undertake to hunt the Atherstone country four days a week and pay the rent of the kennels and leave them in the same repair in which I find them.

"I will do so from year to year without a guarantee, trusting to the liberality of the subscribers, and would spare no trouble to give satisfaction.

"I remain, gentlemen,

"Your obedient servant, "A. Selby Lowndes."

Mr. Lowndes' offer was accepted, and Sir Hanson Berney was requested to continue his valuable services as Hon. Secretary. 


\section{CHAPTER XII.}

THE CRIMEA.

I 854.-The i 3 th Light Dragoons were quartered at Coventry when the order came that they were to proceed to the Crimea. I went the first day's march with them to Rugby, and said "Good-bye" to them there.

\section{“My Dear Jack,-}

"I write these few lines to say that we left Hounslow to-day and arrive at Chichester on Monday, and expect to embark on Thursday or Friday.

"I hope you may be able to run down to see us off, as I should so much like to see you before leaving; but if you can't manage this, I suppose I must now say good-bye, and with best remembrances to Mrs. Thomson,

"Believe me, dear Jack,

"Yours affectionately, "P. H. GOAD.

"P.S. - The cart" is left at ro Chester Street. I suppose you got Jos' letter, and hope you approve of the distribution of the money. The Major, Jos, King, Smith, my brother, and Chamberlayne are with this squadron."

${ }^{1}$ I bought his dogcart. 
"Negociator, 8th May, I2 p.m., 1854 .

"Dear Jack,-

"I was ordered suddenly off, and embarked to-day, only knowing it on Saturday night.

"I did not write to you, as being no post on Sunday it would have been no use. I go in the Negociator (No. 59) - a capital ship. I have a capital cabin as C.O.

"The nags came on board very well, and things have quite settled down now. We sail at seven in the morning. We are now alongside the docks, and Oldham's troop in the Mary Anne.

"We embarked in such a pouring rain, which was a great bore.

"I got your present, which cost $2^{2} 5$ s. - a very good paint-box.

"The dockyard police have just come to say we must put out the lights, so good-bye, my dear Jack, and with kindest regards to Mrs. Thomson,

$$
\begin{aligned}
& \text { "Yours ever sincerely, } \\
& \text { "Soame G. Jenvns. }
\end{aligned}
$$

"Write me a line directed 'Malta,' as we touch there. Good-bye."

"Ship Calliope, 3 rd June, 1854 .

"My Dear Jack,-

"I think you will be glad to hear how we have got on up to this time, so, as we expect to be in Malta by about twelve o'clock, I write these few lines to tell you of our voyage up to this time. We have on the whole had a very pleasant one, and I VOL. I. 
am happy to say that the horror, sea sickness, has not fallen very heavily on any of us, though of course there were times when we did not feel very much inclined to smoke-a sure sign of not being quite right. My brother, Billy Hutchinson and Greatorex saw us fairly off-in fact, did not leave until the pilot returned on the Friday morning.

"After getting out of the Channel we made a good run to the Straits of Gibraltar, and the first few days being calm, we all got into our sea-work very fairly. We got on fairly until the 3 oth, when we were off; but ever since the wind has been dead ahead, and Heaven only knows when we should have got to Malta (being this morning twenty miles from Goys), when to our delight a steamer appeared and took us in tow at 5.30, and we are now proceeding at about seven knots an hour towards Malta. Oh, I have begun this sheet of paper all wrong.

"The ship is a good roomy one, but not a clipper by any means. The Captain, Eagles by name, is a very nice fellow, and we all get on very well. We have on board besides my brother a Scotch assistantsurgeon (Cowan), very canny, and an Irish vet. vice Seymour (Power), quite a wild Pat, without a stitch of uniform or comforts of any sort, and with a monstrous brogue and an unbounded confidence in his own abilities at whist playing-in which game he is singularly deficient in anything but luck.

"The men and horses have all been well, and except a few big legs ('Sphinx' among them from a kick) there is nothing muç the matter. 
“' Freny' and 'Chartist' make wild dashes at every one going by, but as they are both muzzled, do no harm, and are only the occasion of a little extra bad language from any person against whom they may have made an ineffectual assault. We have lots of good plain grub-in fact, it is going nearly all day, and we are getting very much rounder in appearance.

"We play at singlestick, boxing, and all sorts of games in the evening. The men sing, and as I need scarcely add that I am constantly tootling both solos and duets with my trumpeter Davis, I may safely say that we are musical. We were wishing a little to have been at Epsom on Wednesday and Friday, but when you write mind and give me full particulars of everything that has been going on since I left England.

"Of course we are very anxious to get to Malta to hear the news, get our letters, etc., and learn where we are to go to, though I fancy the orders will be to proceed to Constantinople and get further orders there. However I will keep this open until the last, so that I may be able to give you the latest news.

"Pray remember me kindly to Mrs. Thomson, J. E. M., Chetwynd, or any other of my friends whom you may meet, and believe me, ever dear Jack,

"Your very affectionate friend,

$$
\text { "T. H. GOAD. }
$$

"P.S.-Brassel has been getting on very well, and is really a useful man. He left a coat of yours at Half Moon Street. Write to me at Constantinople." 
"DeAR JACK, -

"I am a horrid beast for not writing to you before, but it really is such a bore writing here, what with the heat, flies and no table. I got out to Varna on the 15 th, and disembarked on the 16 th in such a storm. I was very lucky in not losing a horse and landing them all fit to go, and I had a very fair ship, only too small for the purpose, being the smallest out (570 tons). I enjoyed the passage very much, particularly the Mediterranean and the Bosphorus, Greek Islands, etc., which are beautiful. I made several sketches, but could get no paint blue enough for the sea. They fed us pretty well on board, and I was not sick. We touched at Malta, Gallipoli, Scutari and Varna. Tremayne's ship was towed with me from Malta, and we got to Varna three days before Oldham, who was beat. We stayed at Varna three days, and then our squadron, 'Jos' and I, was sent on to Devna, about fifteen miles north. The 17 th and 8th, with Lord Cardigan, were here. We got a deal of kudos about our nags, all others having so many sick and dead. Tremayne only lost one. When we had been here five days our squadron and one of the 8th started under Lord C. for a patrol, as sudden orders came from Lord Raglan to go and find out where the Russians were, as they had left Silistria and not recrossed the Danube, so it was supposed they were near Bassora or on the road to Varna. We were out sixteen days, and have only been back a week, and we found the I I th and the rest of our 
ship's crew here, as also the Infantry Light Brigade. We had a most interesting patrol, but precious hard work. We started by Bagadish and on next day north, but had to return from want of water. The whole country is deserted, not a soul to be seen, and the villages burned down and battered-such a desolate scene. We had only salt beef and biscuits and what we had on. No tents, of course, which in this hot weather on plains is no joke. There is hardly a tree between Bagadish and Bassora, and very little water. We went by long marches to Bassora, where we first saw an enemy in the shape of the Cossacks on the other bank of the Danube looking at us. We bivouacked close to the bank under the old camp of the Russians, which was a curious sight. We then went to Silistria, and when about five miles from it saw the whole camp of the Russians on the other side in such a jolly country, all grass and a lovely view. We stayed all day at Silistria, and it was such a rum sight, the town riddled with shot and shell, and up at Arab Tabia just as it was when they left six days before. The Russian battery being within thirty feet of the Turkish one, the Turks must have fought like demons. We saw 40,000 or 50,000 men encamped about two miles the other side of the Danube entrenched. They don't look like cutting at all, although according to English papers they were said to be in full retreat. There they were, and are now I believe. They had a battery just opposite us on the other bank, about 700 yards across, so we had a good look at them. They had a 
large park of artillery, but not many cavalry. We returned by Shamba. The country about there is splendid. I got ophthalmia from the sun, and have been sick ever since, but am off to-day. All the horses get bad eyes, and have suffered a good deal -four dead on the road, mostly from fever in the feet and the absurd weight we have to carry, conveying besides blanket, etc., etc., two and three days' barley and provisions! They don't give the horses half grub enough. We got tremendous praise from Lord Cardigan, who is a capital fellow to be under at this work. Of course it was exciting up at Silistria, as we expected every day to see a Cossack outpost. We expect to go to the Crimea or . . ., but we know nothing. The Times is our chief authority, though quite wrong about the Russian entire retreat. The regiment has only lost three nags coming out; my own are pretty well. The native horses are clippers, about the size and cut of your grey pony of Cross's. All ponies, but good ones. The soldiers look such oddities-all rags and filth. There are no French here. The flies and heat very annoying. We have regular camp here; races, etc. There is no shooting at present, but it will be good. There is a great deal of bad diarrhœa among the men and officers. Pray remember me most kindly to Mrs. Thomson and Dick Alkin and all friends at Atherstone. How are the dogs? We must have some out here in the winter. We have capital dog hunts with poles on ponies. Wallachia looks such a hunting country to look at, and the finest woodlands about 
Shamba. Tell George Moore. Good-bye, Jack; I hope we shall have a fight soon.

"We had no end of false alarms on our patrol, on which occasions we were very pugnacious. It strikes me you will have to pay for this letter. I have no foreign paper, and my eyes are too weak to write close. Pray write soon.

"Soame G. Jenyns."

"Balaklava, r8th November, I854.

“My Dear Jack,-

"I intended writing you a line long ago, but really we have had so much to do, and when we have had a spare moment too glad to sleep, that I have, I am afraid, been very idle. I am now on board ship in Balaklava harbour, as my old enemy, diarrhœa, has come on again from the wet and cold, and I have been ordered a few days' rest and comfort. You will have seen, alas, in the papers our sad loss. Poor dear old Goad never can be replaced. It is a terrible blow to me and all, and I am sure all old I $3^{\text {th }}$ will feel the same. However, I hope you all need not feel ashamed of the old corps. We were ordered to do a thing that no cavalry unsupported could do. However, we did what we could, and had the satisfaction of sending all the Russe cavalry cutting like a flock of sheep, till we were all nearly bowled over by the guns, as you may imagine when we had only i 10 horses on parade that morning, and had eighty-six killed and ten wounded, and every officer's horse killed except Percy Smith's. The 17 th and $13^{\text {th }}$ went in first line, so caught it worst, 
having a mile gallop up to the guns along a valley with high hills on each side, and six guns in position, besides bodies of infantry on each hill and nine guns in front, which we cleared, standing in the open with not a man near them, but could not walk them off as we had (the wretched remnant) to fight our way back through a fresh regiment of lancers. Never was such a mad order given. Nolan is the man to blame. The last I saw of poor Goad was just going into the guns, on my left. He was killed dead, as the Russians sent back a bill of exchange found on his body. Poor old 'Moses' carried me through like a man and just got me back. He was shot through the shoulders, going right through him, and in the hip joint, besides two grape-shot going into my cloak in front and coming out at the top. A bit of a shell also carried away the end of my cloak, catching me in the knee-however, nothing to signify - so I had a narrow shave. Percy Smith got a prod in the side from a lance, but not deep. I tell you these little particulars which may interest you, as I have not seen the papers. You will be glad to hear I have a good chance of a brevet majority, as Lord W. Paulett told me Lord Lucan had mentioned me in his despatches, and ' if they were liberal, I should get it'. We had nothing to do at Inkerman, all bushes and ravines, although they advanced us as targets. However, all the shot and shell just went over our heads. That was a most bloody business, and you never saw such a scene as the field wasthe Russian bodies were so thick for half a mile that 
I could not ride in places. We picked up 4, I 80 dead. We shall have tough work to get into this place, as we have an army all round us. We had the most awful storm on the r $4^{\text {th }}$, ten ships went down outside the harbour, seven at Chersonese, five at Kictcha, besides we hear all at Eupatoria. You never saw such a scene, tents flying-a sheet of snow and rain-blankets, shoes, busbies and bearskins flying, you could not stand against it at all. The nags are all dying from cold and starvation. You never saw such an appearance as we cut, thirty-two file is all we can turn out! and these like nags sent to hounds to eat, really no better. The heavies' charge was a pretty sight, right in the middle of a plain, only Lord Lucan never gave them a chancelet them receive the charge instead of giving it. However, they threshed the Russe well, although at least six to one. Their artillery is very good indeed-I think as good as ours-and their infantry as obstinate as pigs when drunk, which they always are when fighting. Poor Wynne! ${ }^{1}$ is not it a sad loss? I saw him the night before in such spirits; his head was taken right off by a round shot. How do the dogs get on? Pray write me a good hunting letter, all particulars, horses, hounds, and all. They batter away all day and night at the town, but they have given them so much time that the south side is the strongest now. Lord Raglan gave us tremendous butter in a general 'order,' which, as you will feel an

${ }^{1}$ Heneage Wynne, Captain 68th Regiment, Aide-de-Camp to Sir George Cathcart. 
interest in us all, I will copy. He begins by heading 'The brilliant conduct of the Cavalry Division'. He then congratulates Brigadier-General Scarlett and officers and men of the Heavy Brigade on their successful charge and repulse of the Russian cavalry in far greater numbers, and while he condoles with Major-General Earl of Cardigan, officers and men of the Light Brigade on the severe loss they sustained, he feels it due to place on record the gallantry they displayed, and the coolness and perseverance with which they executed one of the most arduous attacks ever witnessed, and under the heaviest fire, before powerful bodies of cavalry, artillery and infantry. There is a report that the cavalry go to Scutari for the winter to recruit, but I don't think we shall. If we don't we shall be literally dismounted. We are very hard up for clothes, having nothing but the contents of our valises. We get pretty fair rations, and an odd ham, etc., from the ships. I must now stop, so good-bye. My kindest regards to Mrs. Thomson, Waite, Dick Alkin, and, in fact, kind regards to all near Atherstone, not forgetting Cross, 'Daphne' and 'Dahlia'.'

"Yours, ever sincerely,

$$
\text { "Soame' G. Jenyns." }
$$

“Balaklava, 5th February, 1855.

"To J. E. Madocks :-

"My Dear Johnny,-

"I have got the coat, which is the wonder of the camp. I never saw such a splendid coat, such a rare thing to sleep in, but too good to drag out in

${ }^{1}$ Cross, the huntsman; "Daphne" and "Dahlia" two foxhounds. 
the mud. Many thanks for it. I have read several letters from the Atherstone country lately, from Sir George and old Arkwright to Freeman (who is chaplain to our division), from which it appears there has not been much sport there. We jog and scramble on rather in a fix. The want of transport, the origin of all our discomfort, mismanagement, etc., caused more deaths than all the fighting. I live in a dugout tent, which is pretty warm, with a capital fireplace made out of potato tins! French reinforcements keep arriving and a few of ours, but they (i.e., ours) invariably go sick at once. All the fellows here are quite well. We have about forty-five nags left, the IIth I think twenty-five. We could turn out fifty-nine in the Light Brigade and not much better in the heavies. It is too absurd. The roth are on the way. Bosser brought a state on to Lord Lucan yesterday ' 700 strong' (horses); such items as 60 caste cooks, 40 horse keepers, etc. They will be pretty well cut down in these luxuries here, poor devils. I am so afraid they will not send out enough horses and men to us at once, but will send 100 or so at a time. I have no news. We expect an attack on our rear every day, and strong rumours of peace. With best love from Jos and Goad.

"Yours ever sincerely,

"Soame G. Jenyns."

"Balaklava, I5th December, 1854 .

“My Dear Jack, -

"It never struck me till last night that since poor dear Goad's death there has been no one in the 
regiment to write to you, and that you might like to hear how we are getting on. You have, of course, seen all the accounts of our charge in the papers, so I will not try to tell you anything more about it, except that Jenks was worth his weight in gold. He was everywhere, and kept his head as well as if he had been at a common field day. He was on 'Moses'. The good old horse got shot in four places, and was only just able to get back to the heavies behind whom we formed up.

"A few days after the fight we moved our camp, and went to the rear of the Second Division, on the extreme right of our line, so we were under fire again on the $5^{\text {th }}$ of November, but luckily escaped without loss. Our next 'grief' was the hurricane on the I 4th. It was bad enough for $u s$, but still worse for the horses. We lost thirteen in five days from the effects of that one day's cold and wet. We then remained in the same place for a fortnight, during which time the horses got no hay, and about three pounds of oats each a day! Our commissariat transport is so very bad that they could not manage to get up any more for us, and on two occasions they could not even bring up biscuit for the men. At last, on the 2nd of December, they sent us an order to move down to our present position, so that we might be near our supplies. You never saw such a sight as our march! The horses were so weak that riding them was out of the question, and the brigade had to put their pride in their pockets and walk down, leading their horses. Even then about ten had 
to be left. We are now about a mile from the town, so we get our forage regularly, and the horses are beginning to pick up a little, with the exception of those that were too far gone. Our effective strength is seventy men and twenty-eight horses! There are fifty horses on the ground altogether, but the remaining twenty-two are in the sick report. What a regiment! They employ 500 horses of the Heavy Brigade every day in taking up rations to the infantry, so out of our twenty-eight horses we have to find our proportion of the outlying picquets, and also to draw forage for ourselves and the heavies. Just as much as we can do.

"Jos Tremayne and Jenks are both here and flourishing, and the subs. are Jervis, young Goad, Chamberlayne and myself. This is desperately dull work and not very luxurious. I confess I should prefer Atherstone, and we might really just as well be there for all the good we can do at present. How are you all? I hope your wife is quite well. Pray remember me to her and to Sir George. I don't know whether Jim Oakeley is at the 'Château Briggs' or not. If you see him, will you tell him that I think nothing of him for not having written to me. I hope you are having good sport this season. We always make a rush at Bell when the papers arrive, in the hopes of seeing a 'splendid run with the Atherstone,' but as we have not had good luck to see that yet, we generally end by looking over the meets, and Jenks always has some run or bit of a run from at least one, if not two, of yours, and that one column 
of Bell lasts us an hour or two. How is Cross? I hope my old friend 'Artist' "has distinguished himself-not in the retrieving line only. How I wish I could see you, even on a pony, and at Hams Hallalthough the foxes do go there in gigs, ${ }^{2}$ eh! Jack? I can scarcely tell you anything about Sebastopol, for one hears so many different stories in the course of the day that it is very hard to know what to believe. The latest 'shave' is that the Russians are getting their fleet ready for sea, and that they intend to run the gauntlet of our ships and try to get away. 'I tell you the tale as 'twas told to me,' but I cannot fancy that it is at all probable. They say we can take the lower town when we please, but that we shall not do so until our own and the French reinforcements arrive. I wish they would make haste. The Russian fire is nearly as strong as ever, so I fear we have not finished our job yet, and I should not be surprised if it lasted a good deal longer, for all the strongest forts are on the north side of the harbour, and we have not fired a shot at them yet. Never mind, they say 'patience is a virtue,' and you will probably consider yourself virtuous if you manage to read my letter as far as this without being disgusted at the want of news in it. Good-bye.

"Believe me,

"Yours very truly, "Percy Smith.

${ }^{1}$ A hound which was taught to carry a stick while a puppy.

${ }^{2}$ I believe a bag fox was turned out at Hams Hall, 
"Jos begs me to say that 'his life is a burthen to him (out here),' and Jenks orders me to tell you that you are a brute for not writing to him."

Sir Arthur Halkett, who carried the colours of the 42 nd at the battle of the Alma, writes :-

"I have read the little book by Sergeant Mitchell of the I $3^{\text {th }}$ with much interest, and it recalls many scenes. He does not exaggerate any of the miseries of the men and horses.

"I was in a house at Kadekoi where the cavalry and horse artillery were, which was used as an hospital for my regiment, and I lay for three or four weeks looking out upon a battery of horse artillery. The horses stood up to their hocks in snow with a thin blanket on them which generally blew off. They had eaten the spokes of the gun carriages all away, and as much wood of the limbers as they could get at.

"One day in November the camp was invaded by ravenous cavalry horses, which had broken loose at the sound of the feeding trumpet, and galloped madly, snatching at the hay and barley, undeterred by the sticks and stones of the gunners.

"I recollect one night in the trenches, when a man was killed and carried out to the open ground in front to be buried; the Russians heard them digging the grave, and they had just placed the body in it, when a shot came and killed one of them. The survivor laid his comrade's body by the other, buried them both, and returned to the trenches."

A Russian account of the Light Cavalry charge at Balaklava :- 
"Another guest arrived. It was Count Stroganoff's steward, a retired major of hussars, now close upon seventy, but as smart and as dandified as a young fellow of twenty. Ivan Ivanovitch had received his commission in 1848 , and had been through the Hungarian campaign and the Crimean War. He was wounded at Balaklava, and gave a vivid description of the historical 'Charge of the Light Brigade'. "“ 'We were sorry for them,' he said; 'they were such fine fellows, and they had such splendid horses. It was the maddest thing that was ever done. I can't understand it. They broke through our lines, took our artillery, and then, instead of capturing our guns and making off with them, they went for us. I had been in the charge of the Heavy Brigade in the morning, and was slightly wounded. We had all unsaddled, and were very tired. Suddenly we were told "The English are coming". "Confound them," we said. My Colonel was very angry, and ordered his men to give no quarter. I was lying at some distance, with my wound bandaged, when I saw them coming. They came on magnificently. We thought they were drunk from the way they held their lances. Instead of holding them under their armpits they waved them in the air, and of course they were easier to guard against like that. The men were mad, sir. They never seemed to think of the tremendous odds against them, or of the frightful carnage that had taken place in their ranks in the course of that long, desperate ride. They dashed in among us, shouting, cheering and cursing. I never 
saw anything like it. They seemed perfectly irresistible, and our fellows were quite demoralised. The fatal mistake we made in the morning was to receive the charge of your Heavy Brigade standing instead of meeting it with a counter shock. We had so many more men than you that had we continued our charge downhill instead of calling a halt just at the critical moment, we should have carried everything before us. The charge of your Heavy Brigade was magnificent, but they had to thank our bad management for the victory. We liked your fellows. When our men took prisoners they used to give them our vodka. Awful stuff it was! More like spirits of wine than anything else. Your fellows used to offer us their rum in exchange, but we did not care for it ; it was too soft and mild. The Russian soldier must have his vodka."

"BALAKLAVA, 2nd January, I855.

"Dear Jack,-

"I cannot tell you how we all devoured your letter with all the hunting details, just what interests most out here. I am very sorry to find, though, that you have never got a long letter full of all details. I wrote to you about the 7 th November, I think, as I knew you would, of course, be as anxious as any one to hear about our sad losses, and above all about poor dear old Goad. Oh, Jack! I cannot tell you how we do miss him, or what a blow it is to us all. And I know it will be the same with all

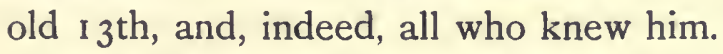

"As you must ere this have got my first letter, voL. I. 
and have also read many accounts of that disastrous day, I will only refer to poor Goad. The Times special correspondent is the only. true account (flowery, of course, but quite correct) of that day; half the other accounts, and illustrated pictures, lies from beginning to end. We were, as you know, ordered to charge down a valley a mile and a quarter long, flanked by hills on both sides studded with guns and infantry, and eleven guns in front (the ones we were ordered to 'retake'), their cavalry, about 5,000, drawn up close in rear of them. The instant we advanced we were in range, and over went men and horses by threes and fours all the way. We should all have been knocked over only we went as hard as we could split, and they did not shoot forward enough from the flanks. The last I saw of poor Goad was about I 50 yards from the guns, when the smoke was so thick we could see no one. Some men saw him lying on the ground wounded, but, of course, having to fight our way back, could not help him. Oldham I saw killed by a shell which burst under his horse, and knocked over two or three others. It blew his mare's hind-legs off, and he jumped up himself not hit, when next moment he threw up his hands and fell dead on his face. Montgomery was my right troop leader (first squadron), and I saw him safe into the guns ; after that, on returning, he was seen dead on his face, poor fellow. Our wretched remnant, when we got to the guns, went with such a right good cheer, bang through their cavalry, which cut right and left like sheep; on rallying back there were 
the guns 400 yards in our rear all clear, and no one to carry them off - the worst part of all - as a very strong regiment of Lancers came on our rear, and we had to cut our way through them. Lord Lucan never supported us, the Scots Greys, the nearest, at least a mile in our rear!! The $13^{\text {th }}$ and 17 th lead thus :-

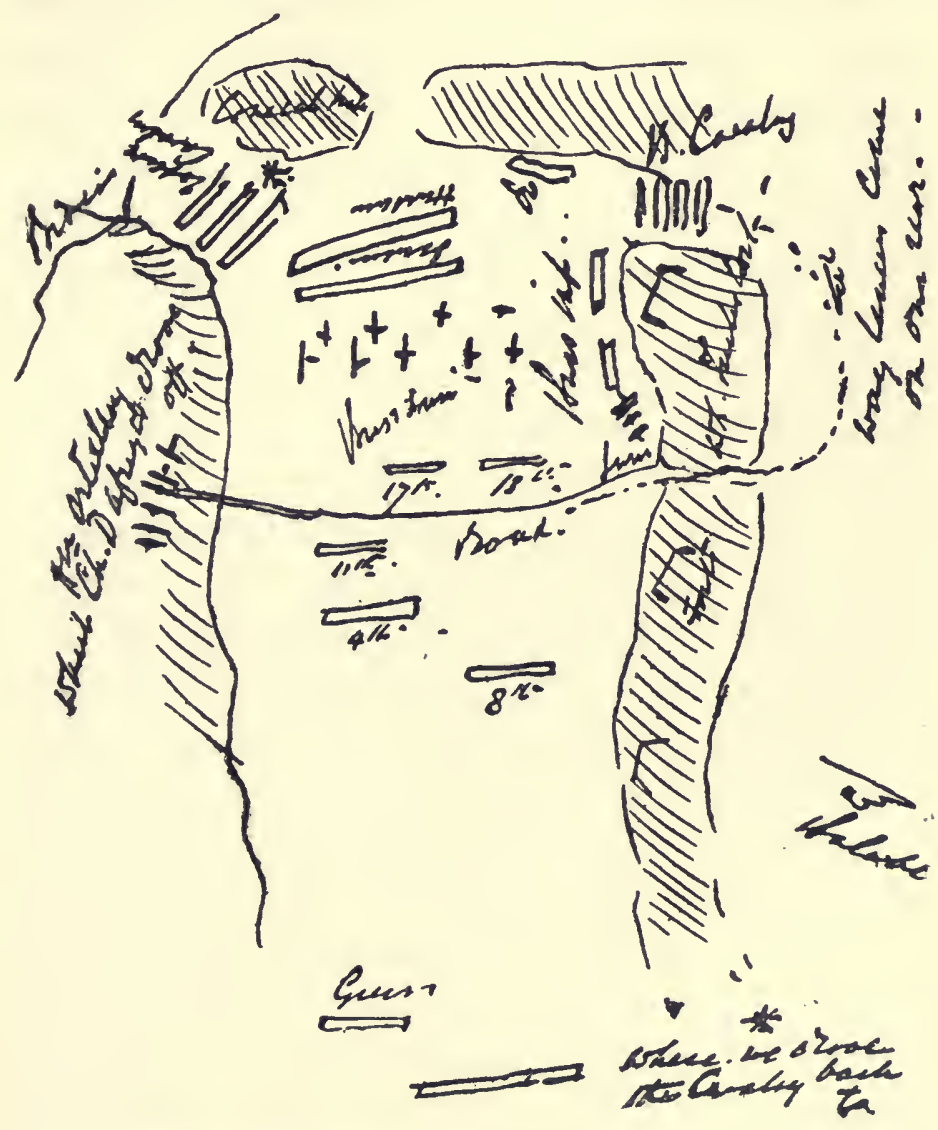

"I have drawn a rough plan to try and help you to understand it, the shaded part high hills. All the returns are wrong in the papers. We had IIo 
horses and eight officers when we went into action (young Goad's horse, the one he jumped the timber on, was knocked over by a round shot early in the day, and the young 'un hurt in the fall), seventy-six troopers' and seven officers' horses killed on the spot, ten shot afterwards, and eight wounded still alive. I only brought nine mounted men back! Poor old 'Moses' was shot through his shoulder and through the hip into his guts, but just got me back. I had some narrow shaves, as, indeed, we all had. My cloak, rolled in front, had three canister shot through it, besides a piece of shell knocking off the end of it, and catching me on the knee, but only a severe bruise. Percy Smith's horse was the only one not killed. Although so cut up, you will be glad to hear the old corps got tremendous kudos from all. It was a fine sight to see the fellows sit down and put their heads straight at the guns. The heavies' charge was a pretty sight, only so badly handled; they never were let at them till too late to gammon a good gallop ; and then the Greys, who had a little, pulled up and began to fight instead of boring through them. They get all the kudos, which they far from deserve, as the Inniskillens did the business, and right well too. They put us under a very heavy fire at Inkerman, but luckily for us-no thanks to any General-we had a slight rise on our flank, which ricochetted the balls just over our heads. Some ship shells bowled over some few men and horses though. It was useless exposure, as we could not act. Lord Cardigan is plucky, but no head or temper. As for 
Lord Raglan, he has not once literally been in the cavalry lines or seen our wretched state, and, whatever may be said, was not on the field at Inkerman till two hours after it began. The Duke behaved most pluckily. Nearly all our nags are dead. They stand up to their bellies in mud, have to fetch their own grub four miles, besides carrying provisions all day six miles to the front-all from want of conveyance in that infernal commissary. It rains all day and freezes at night, but no cold to hurt any one yet. We are all capitally fed, and I have no patience with grumblers on that score, but no care of horses taken. Here are the huts, clothing, etc., all at Balaklavaall very pretty on paper, but not an animal or cart in the commissary to carry it up; the guns the same. The infantry actually carry up the shot, in long strings, eight good miles from Balaklava to the trenches, up to your knees in mud.

"We are living in the deepest ploughed field, like Burbage Wood on a wet day. If we had conveyance in the commissary we might have hut stoves and no end of luxuries from Balaklava-all there-but here we are, the and January, and no better off for cold, except about twenty fur coats in each regiment for picquets, and rotten Turkish boots for picquets too, and a few horse-rugs, than we were in July -all from no conveyance in the $\mathrm{d}-\mathrm{d}$ commissary. No one can believe our bad management alongside the French unless they see it. The men can fight though, if the commissary can't comfort them. 
"We have the best of it now, and expect to see the inside of Sevastopol very soon. I hope they will send out some cavalry soon, as we are too weak to gammon a trot even, and we have only fifty-two nags left; about the same in all light regiments, the heavies a shade better in numbers. Our chief, Jack, won't do at all in any way. I wish you would exchange with him, only he would not do for the hounds either, I suspect. He never moves out of his tent, lives with the vet., Firth and Chamberlayne, and don't do at all in the field.

"Have you seen the Major? (entre nous) is he very seedy? Jos, Percy, Jervis (much improved) and young Goad are here all well. I am a respectable Major now, as you will have seen. I got the paint-box at Newman's, Soho Square, but think I paid for it at the time. I cannot paint here, having no table, as I have only the contents of my valiseall my traps left at Scutari. Give my love to Johnny Madocks and Oakeley, and ask Madocks what Brown means about a coat? I was going to write to him this post, but this will do for you both.

"Brown says he ordered a coat for me, but I have not got it yet. I am very much obliged to the dear old boy, as it is just what is wanted. Tell him I am as bald as he is, having lost all my hair from fever I had. I can't keep quite well out here-bad place for one's guts.

"We all spelt the run in Bell from Bosworth, and much amused at the list of performances on the occasion. 
"Give my love to Dick Alkin, Cross and all, and pray remember me most kindly to all Atherstone Field; often do Jos and I talk over days spent there.

"With kindest regards to Mrs. Thomson and the kid.

$$
\begin{aligned}
& \text { "Yours very sincerely, } \\
& \text { "Soame G. Jenyns. }
\end{aligned}
$$

"Jos and all send their best love, and happy New Years to all."

$$
\text { " io Chester Street, 6th January, I } 855 \text {. }
$$

"My Dear Thomson,-

"I have only returned from the Crimea a few days, or should have answered your very kind letter sooner. I left on the I 3 th November, as soon as I heard that my poor brother was missing. I made every enquiry there. The only thing that is certain is that a man in the $13^{\text {th }}$, of the name of Farringdon, who, from some cause, was one of the last in the retreat, saw him at the Russian end of the valley, half-sitting up, with his revolver in his hand. He was then wounded in the lower part of his face or neck, but might also have been elsewhere; even then it is certain that he was either then or afterwards wounded in the chest, for the paper which he had in his breast pocket, and which the Russians sent back, was covered with blood. There are other stories about other men having seen him, but I could not make out that there was any truth in them. 
You, who knew him so well, can imagine how we feel his loss. As for myself, I can safely say that I have lost as affectionate a brother as ever man was blessed with. I stayed in camp about a fortnight. Owing to the neglect of the commissariat officers' reports, the Light Cavalry have since that advance lost more than half the horses, and Lord Raglan then says it is the fault of the officers for not looking after things, and that the men have been selling their forage to the French. You can imagine the rage of Jenks and Jos when Lord Lucan told them what Lord Raglan said. Left the Colonel, Jos, Jenks, Percy, Jervis and my brother there, all well ; Chamberlayne too.

"Believe me,

"Yours very sincerely,

"Charles W. Goad."

"Camp, Balaklava, I2th February, 1855.

"My Dear Captain,-

"Knowing that it will afford you as much pleasure to know, as it does me to inform you, that I have received a commission in the $\mathrm{I} 3^{\text {th }}$ as Cornet and Adjutant, I now take the liberty of addressing you. First, let me return you many thanks for your very great kindness in first pointing out to me the proper path to such promotion, and affording me every support in the performance of my duty while a non-commissioned officer in your troop.

"I am sorry to inform you that poor Mr. Irwin 
died of cholera on board ship on the 26 th September, and I know you will say with me that he will be missed in the reorganising of the regiment, and more particularly so when I give you the state of the regiment as it was sent in this morning :- Horses : Fit for duty, twelve; sick, twenty-seven; detached, five-total, forty-four. That is all the horses we can muster out of 250 we left England with, and as to try to put one of them into a trot you could not.

"Many are the enquiries of what do they keep you here for, and the only answer to this is that they want to kill the remainder dragging up their own forage. I am happy to see that we are to get a clasp for Balaklava, for I think we deserve it. Our men have suffered almost as much as the horses, for out of 298 all ranks, we are now eighty short, besides fifty-four sick at Scutari. I for one should not be surprised if we lost all, for these canvas walls are no joke. They are very well in fine weather, but that is very rare here.

"The troops are being supplied with good boots and warm clothing now it is, I am afraid, almost too late. We have got our huts up for our horses, and when it don't rain they are almost as comfortable as they were before, but when it does rain, then don't they catch it!

"We are still on the alert, expecting an attack from the Russians, but they do not like to come; and, in fact, we are like two dogs over a bone, one is afraid, and the other dare not touch it. 
"I ask your pardon for the liberty I am taking in thus addressing you, and have the honour to remain, "Dear Captain,

"Your ever obliged servant,

"Geo. Gardner,

"Cornet and Adjutant, "I $3^{\text {th }}$ Light Dragoons."

One evening, at Bath, 6th July, I890, Sir John Ewart came in to Mr. Davies' after dinner. Davies said, "I have an interesting letter from a Dr. Mowatt describing the rescue of Jacky Morris, of the I7th Lancers, after Balaklava charge".

Sir John said, "I can tell you something about that, for I found him. I was on Sir George Cathcart's staff, and we were ordered to retake the redoubts on the right, which had been abandoned by the Turks. At this time we did not know that the Light Cavalry charge had taken place, as there was a line of hills between us. I rode forward, and was met by three or four, whom I took to be officers. One of them said, "There is a staff officer badly wounded lying there,' pointing behind him. They passed so quickly that I could not make out who they were. I had a good horse, so I rode in the direction, and found Morris on the ground badly wounded. Morris had been employed on the staff. Colonel Willet had become sick the day before, and Morris was sent for to take his place, and he had on his staff uniform and forage cap. I said, 'Hullo, Morris! What has happened ?' and raised him up. 
His head fell back, and he could not speak. I tried to get him on to my horse, but could not. I then mounted my horse, and saw Nolan lying quite dead. I also saw a man of the $5^{\text {th }}$ Dragoon Guards with an awful wound across his face, his lower jaw being almost cut off. He was sensible, and I asked him what regiment he belonged to. $\mathrm{He}$ pointed to his button, and I saw ' 5 ' on it. I rode back to the redoubts, which had been again occupied by the Turks, and made signs, as I could not speak Turkish, and induced eight of them to come. I put four of them to carry Nolan's body, and four to carry Morris. The Russians having again opened fire, the Turks threw them down and ran away. I then met a man on horseback whom I took to be a middy, or some one from Balaklava, and said, 'Do you know where the Light Cavalry camp is?' He said, 'Yes, I know well.' 'Gallop as fast as you can, and say the commanding officer of the 17 th Lancers is lying badly wounded.' After some time, two men bearing a stretcher, and a doctor appeared, and removed Morris. I saw the doctor dressing his wounds. The doctor's name was Mowatt. Two more stretchers came, and Nolan's body was removed, and also the 5 th Dragoon man. Some months afterwards I saw that Dr. Mowatt had received the V.C., and the two men who carried the stretcher."

Sir John Ewart also stated that while he and Sir George Cathcart were together Lord Cardigan rode up to them at a walk, and said, "I have lost my brigade". They did not know what he meant, 
and stared at him without speaking. He turned his horse and galloped back towards the Russians.

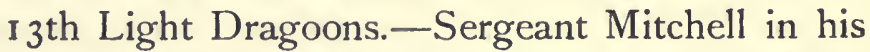
account says: "We were now very close to the guns, for we were entering the smoke, which hung in clouds in front, and could see the men running away from the guns to the rear. My horse was struck with a shell and fell on to my left leg. The 4th Hussars passed over me without hurting me. I then extricated my leg, and started with a man named Pollard to get back. We got separated, and I found myself alone. Just then Lord Cardigan came galloping up from the direction of their guns, passing me at a short distance, when he turned his horse about again, and meeting me, pulled up and said, 'Where is your horse?' 'Killed, my Lord.' He then said in his usually stern, hoarse voice, "You had better make the best of your way back, or you will be taken prisoner'. He then rode a little way further down, and in a few moments returned past me at a gallop." ${ }^{1}$

${ }^{1}$ This must have occurred before he spoke to Sir George Cathcart and Ewart. 
CHAPTER XIII.

BICESTER.

Having decided to leave Atherstone country in I 855, I thought I would have a try for Cottesmore, as Burrowes was giving up there. I went and stayed with him at Cottesmore Hall. Most of the gentlemen in the country received me favourably, but Lord Wilton went dead against me; and as he had much influence with the Melton division that made the Melton subscription doubtful.

Lord Chesterfield and a large party came over from Bretby one day to Gopsall to report on Atherstone Hounds. Unluckily, being near home and an easy place, we brought out all the hounds that were short of work. There was little scent, lots of foxes, killed one, but did no wonders. So the hounds were evilly reported on and crabbed. However, I got on so far at Cottesmore that I began to take the inventory of the furniture in the house. I had also been in correspondence with Sir Henry Peyton about the Bicester country, and I got a letter from him saying they agreed to my terms.

I succeeded Tom Drake at Bicester, who had to give up, having hurt his back. He lent his hounds to Sir John Trollope, Cottesmore country. 
Selby Lowndes succeeded me at Atherstone; Whitehall went with the horses to Stratton Audley. I took over the house from Tom Drake, and bought a lot of his furniture.

Cross came with the hounds. I engaged Tom Powell, Mr. Drake's first whip, and put young Cross on as second. I wrote to Cross to have everything ready, but not to go out till I came.

My son Charlie was born in Edinburgh on 6th May and named after his two grand-uncles, Admiral Sir Charles Adam and General Sir Frederick Adam.

\section{"Curzon House, Tuesday, May, 1855 .}

"This is indeed joyful news, my dear Thomson, and I do most heartily congratulate you and Mrs. T. on her safety and speedy safe termination of her troubles. May 1 live to see No. 2 on pony-back after the hounds.

"So you are embarked in Oxfordshire! All happiness attend you wherever you go. We shall sadly miss you indeed, and be long ere we see your like again. You will rejoice to hear the foxes, cubs, swarm at old Gopsall.

" Ever most truly yours, "Howe.

"The two young ladies beg their love to you both. . . . Curzon House, where there is luncheon at two, if you wander up to town."

I went to Stratton Audley on the 8th September, and found that Cross had been out the day before. 
I found fault with him for this, and he appeared to be very stupid and sulky. Next morning they were to meet at Dedham Hill about twelve miles off. I was at breakfast about three A.M.-pitch dark-when I heard the hounds trot past pretty quick. I ran out with Will Horton, my second horseman, got our horses, and off we went ; did not know the way, and followed them out of the village by our noses. It was a fine fresh quiet morning. We never overtook them till we got to the place of meeting. "Charm" was standing with her head stuck out, covered with foam, and all the hounds panting like to burst. Found a lot of foxes in a bean-field and killed a brace.

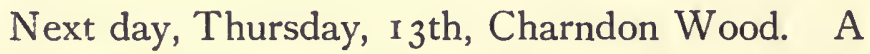
very wet day. Cross quite stupid. He thought they had killed a fox in covert. He went in on foot and came out after about half an hour wet to the skin, his face all scratched, and his clothes torn, and on his way home his pony shied, and he bundled over its head.

Saturday, Gravenhill. Cross quite off his head. He trotted about view-holloaing in the opposite direction to the hounds. I was obliged to take hold of them myself, and killed a brace of cubs. On getting home sent for the doctor, and told him he must keep Cross in bed.

I wrote to Dick Alkin to come and help me, and he came at once, and asked the doctor at Nuneaton if he would take care of Cross, as they had been great friends in the Atherstone country. 
Dick and Cross were to start at one o'clock. When we came in he was still in bed with his wife. She had a wash-hand jug of gin by her bed-side. I went into the room and said, "Come, Cross, get up". He jumped up and dressed, never said a word, and got into the fly and went away. I sent Mrs. Cross and the children into Bicester, and the chief constable, a very nice old man, looked after her -but she was not to be trusted. Cross got much better at Nuneaton, and went out in the doctor's gig when he went to visit his patients.

One Saturday the hounds met at Arbury, close by, and the doctor let Cross ride a pony. After being out an hour or two, he said, "Now, Cross, you had better go home". He trotted off, and did not come home that night. Next morning a farmer found him asleep on the side of the road near Lichfield, sixteen miles from Atherstone. He put him into his gig, took him to the White Hart at Atherstone, and put him to bed. The landlord had been Sir George Chetwynd's groom, and knew him. The pony was not found for a week. He was at Smockington Hollow about ten miles off, on the road to Rugby.

His account of himself was, he rode the pony to a standstill, and then got off and walked. He came through a town by lamplight, and got over the railway gates at a level-crossing, and walked until he was so tired he sat down and fell asleep.

The doctor would have no more to do with him. Lord Howe kindly got him admitted to the hospital 
at Birmingham, and he was removed to the asylum at Warwick, where he died. He was a good, honest chap, devoted to hunting, and a good hound breeder; but his wife was a she-devil, very good-looking, with the manners of a duchess, and she was the ruin of him.

Letter to my wife :-

\section{"Stratton Audley, \\ "Monday evening, I7th September, 1855 .}

"I was too sleepy to write to-day in time for the post, and I don't know which is stiffer now, myself or 'Charlie' (the terrier), who is asleep in the corner; but I rode on a saddle which was too short for me, so my seat is less comfortable than his. I can tell you my bed has not been a bed of roses since I came here. In the first place, the first night I came into this house it was so hard, being only cushions and no mattress, that every time I turned I woke. Now the mattress is too big, and I am hedged in and can hardly turn at all.

"First, my feeder absconded, then Cross was taken ill-in fact, has been so ever since I returned. $\mathrm{He}$ was so drowsy and stupid that I thought he would have a fit. He could not feed the hounds, and was useless in the field, and all the time said he was quite well. But I could not stand it any longer, so I sent for the doctor on Saturday, and we have got him in bed with leeches on the back of his neck. He is better to-day, and I hope'will soon get out; but I have had to feed the hounds myself and hunt them too. 'They nearly had their eyes torn out, and ran six hours in a VOL. I. 
big wood, but we could nọt catch one. I got on very well, and my throat is all right, but I am as stiff as a post. Tom Powell, my new whip, is a first-rate fellow. I wrote to Dick Alkin to tell him I was in trouble, and like an old trump he came over directly on Saturday. He could not stay, but has promised to come back to-morrow or Wednesday, so I shall do well enough when he comes-in fact, I can fight on now, but this illness of Cross's, if he does not get well quick, may keep me here longer.

"Hervey Farquhar has been here this afternoon. $\mathrm{He}$ wished to buy Brackley some time ago. They asked $£_{3}, 000$, so he declined it, and has taken a place for two years in Northamptonshire, which he has furnished and put in order. The price of Brackley then drops to $£ 2,150$. He would like to buy it but does not want two houses at once, so his buying it is contingent on my taking it for the mother. We may give it up when we like or keep it nine months, he says. He asks a Jew's rent, but he is so hampered with the other house and having to furnish two at once, that he would rather let it for a long time at a lower rent than a short time. He is a capital fellow, and was very good to come over to see me about it. He came from London to Brackley.

"Tuesday morning.

"As no answer has come from the mother, I have closed for the house. A dry situation, heated with hot water, and a cheery drawing-room were not to be overlooked, and it is the best situation for hunting possible, so the business is settled." 
John Madocks protested against my hunting the hounds, and sent me the following letter :-

"Glanywern, Denbigh, 3rd October, 1855.

"My Dear Jack,-

"I was delighted to see your small handwriting yesterday outside a letter, as I was anxious to hear how you had been going on. Poor Cross! I am so sorry for him, and I fear that 'water in the head' at his time of life is a very bad look-out for him, and that he will never be able to hunt hounds again. You really must not attempt to do the work yourself. Before you married you were at perfect liberty to kill yourself, if it suited your fancy; but now it is quite different, and $I$ think it very wrong of you even catching hold of them for one day-eight days, perfectly shameful. Cutler told me this year in London that unless you had taken the greatest care of yourself and acted up to his orders implicitly that you would not have recovered. One hard day's holloaing might put you all wrong again, and you would probably never recover. Do not think this wigging all bosh, etc., for I really mean it, and trust you will take my advice, and leave the hunting to $T$. Powell, who I have no doubt has, what you have not, the constitution of a horse.

"I have been here and hereabout ever since you last heard from me, with the exception of a week's visit into Yorkshire. I have had capital sport shooting. Sir Robert Vaughan left us this morning. He had a great hunt yesterday and killed an old fox sup- 
posed to be a 'Binks'. How nice for you having your mother and sisters so near. We have been a large party here for some time-Mrs. Beech and her children, etc., etc. Do you recollect a cousin of mine, the youngest Miss Williams, a good-looking girl? She is going to be married to Sandbags. They were staying here. I asked him on purpose to meet her as I knew he was sweet, and it, i.e., the proposal came off here last week. The Bird ${ }^{1}$ I really could not tie up : it was so very far off that I could not spare the time-some forty miles from a railroad. I shall be charmed to pay you a visit some time, and see your new country. Write here; I remain till about the $15^{\text {th }}$, and then take my sisters to Eaton Place to pack up and give up the house there as they have let it. "Mind my advice.

$$
\begin{aligned}
& \text { "Yours ever, } \\
& \text { "J. MADOCKs. }
\end{aligned}
$$

"Watkin is far from well, and is gone to town for advice. He will very likely have to go to Germany for two months."

I wrote to my wife :-

"Stratton Audley, 7th October, 1855 .

"I begin to see a little daylight. I have got Cross disposed of, and now my hackles are rising, and I can speak plain English to his she-devil without distressing him. On my return home to-night I found she had not been out of bed for two days, so I

${ }^{1}$ Felton Hervey, late 13 th Light Dragoons; he was Inspector of Prisons in Ireland. He was about to get married. 
broke open her cupboards, and got the remains of two gallons of gin. I will soon dispose of her now, but I don't know what to do with her little boy and the old woman.

"A new whipper-in has come to-night, Morris by name, formerly with the Warwickshire, so I hope to start Tom Powell soon, and be able to return to you. Tom is much more valuable than Will would have been here, as he knows the country. He also has a better voice, and Will was a little deaf. He is light and a capital horseman. Young Cross has nearly had his toes cut off by the coach-house door falling on them, so he has not been out for two days, but he will be on Monday.

" Now I must tell you of my travels. I went to Bletchington on Thursday to dinner, Henry Peyton, Lady and Algernon dined there, and two Fortescues. We had a good hunt. Mr. Morrell was there, and his huntsman, Tom Clarke, once my whip. We had a good day's sport and caught two vulps, and I rode 'Charm' on Friday. After hunting we went into Oxford-Valentia, Corbally and myself-and dined at Mr. Morrell's. He is jolly, fat, hospitable, sensible and a brewer. His wife is handsome and good-natured, and has a little girl not quite two years old. He mounted me to-day with his hounds, and I came home by train, and here I am trying to overtake my letters and unravel Cross' accounts, which are in sad confusion. But I am quite well, and not at all inclined to be beat by anything.

"How are my little boys?" 
Stratton Audley, I 855.-I then commenced to hunt the hounds myself, and very soon got Morris, who had been with the Warwickshire, as second whipper-in, and got on capitally with him to assist me. Morris was invaluable in the great woods at Claydon. On running into the centre ride one day, I said, "Well, Morris, is he over?" "Four over, but not the right one ;" and while speaking, he says, "Here he comes".

I divided the hounds into two lots-black and white. It made almost an equal division of dogs and bitches, and also of ages, and they looked very nice. Once a fortnight we had to meet in the Chipping Warden country (eighteen miles), and it was a troublesome business getting there. The horses went on over night ; I drove the van as far as Farthingho, where we left it. We then rode the leaders across the fields to Chipping Warden, where we got our hunters. The helpers then returned to Farthingho with the horses we had ridden. After hunting we returned to Farthingho, put hounds into van and made all the men come in and have tea with me. Sometimes the horses did not get home till ten and eleven at night.

I first began to use a whistle when I took this country. I liked the Bicester country better than any I ever hunted, and I had the best sport I ever had. The fences suited me well, as I could crash through them. There was plenty of grass, but it rode heavy. 
"Appleby Hall, Atherstone,

" 22nd November, 1855 .

"Deak Thomson,-

"My best thanks for your letter, received this morning, and the account it contains of your sport and hound list. I' am afraid I cannot come to you just at present as my boys come home from school on the I Ith of December, and I have a houseful of people next week. I must come the end of January or beginning of February, if I can. It takes me a long time to write a letter-I proceed by fits and starts. I am glad your sport has been good. That must have been a good day. from the Claydon Woods. They are fine large coverts. How do you like your country? It is long and narrow, and are the foxes any better than this country? You are a curious man about your white and black pack. All very well if the hounds happen to divide pretty well that way as to age. I am indifferent as to size, and prefer dogs and bitches mixed; but if any of your one-year-olds or young ones want going out three days a week, which many will, especially one-yearolds, I suppose he must not go if black, or white as the case may be. All hounds should go out of their turn if they require it. Does Webb ever come out? Do you know Arthur Venables of Oxford (at the Mitre), an old friend of mine and Mr. Drake's, and a good sportsman? Do you ever see or know anything of Tom Drake, or what he is doing ? I suppose you will not come down here? If you could at any time, Mrs. Moore and I shall be glad to see 
both Mrs. Thomson and yourself and the young ones, but I suppose you are too busy.

"Now about the Atherstone country. I have been out several times and do not see much to admire (private). I do not consider Lowndes a huntsman (independent of jumping). He often leaves his hounds behind, and does not look if they are coming after him, and he did not work them half enough cubhunting, and consequently the riot is tremendous, all breaking away at times. I believe he does not like them punished for running loose. It may possibly be overdone, but the other way is as bad, and cubhunting is of no use beginning at I I.3O in September. Lowndes' hounds are good hunters, and put their noses down, and with a good scent will work quiet; but if it comes to a doubt about scent, I think both Lowndes and Dickens will find it hard to discriminate between right and wrong. However, I am much obliged to Lowndes for taking the country. If he had not come forward I do not think any one else would. As he will spend some money on them we must do the best we can to help him, and I am sure I will try to do it.

"Tom Leedham had killed eighteen brace up to last Saturday, and driven every fox out of Bagots Woods. It will be a rare place this spring. I intend to hunt a great deal on that side if I have my health. He is the only man I feel happy with out hunting. I always think he does right, and never see him do a thing without a reason. Of course, there are many cases of even betting, and no man 
can always go the right side first, or kill every fox he hunts.

"Geldart is here this winter, and has taken Mousley's house at Hanuton, and we have a hunter at Stretton, one Consan. I think he appears to be a good party. I do not think they will get a pack of hounds together in Leicestershire this winter, ${ }^{1}$ if at all-no one will like to undertake it. We have not had much sport, if any. Meynell Ingram's or Lowndes's hound list I have not seen. I will forward one when I get them. Good luck to you and good sport. You should have stayed here until you returned to Fife.

"With my kind regards to Mrs. Thomson,

"Believe me,

"Yours sincerely,

"G. Moore."

On 23rd December, I856, I wrote to George Moore :-

"I have had such a run last Tuesday as I never saw before, so have taken a large sheet of paper to tell you all about it, and have, moreover, made a map for your benefit as you know the country.

"Met at Charndon Common; sharpish air, but fine still morning; twenty couple white hounds, my pack. Found two or three foxes in Charndon Wood, and I intended as soon as we had made a row in the wood to cut away to the end where a fox

${ }^{1}$ After Sir R. Sutton's death Frank Sutton and Mr. Clowes got a pack of hounds together, with old Tom Day as huntsman, and hunted the Quorn country the rest of the season. 
generally breaks. However, before I got there, two were holloaed away. In going up the ride I crossed two lines of foxes, and some hounds broke away on each, so I arrived with only four couple. However, they came dropping on, and as soon as I got twelve couple I went away with them. We had just got over the Edgecot road and down the hill, where our fox had turned to the right, when something headed him, and he turned back in front of the hounds, in the same field with them, and away they went over those fine grass fields. Somehow another fox appeared, and the two ran close together up to the Grendon and Marsh Gibbon road. I had a bad start, being the wrong side of a big fence, and only caught them there. The fox had run up the road towards me, and gone through the gate opposite to which I came into the road. The twelve couple on the line were two fields to my left, and five couple scoring to the cry in the next field to me. When I whistled the five couple nicked the scent first, and then away they went in earnest-seventeen couple over Marsh Gibbon Field, all grass, very deep, double fences and brooks. We began by crossing the brook twice, a double which thinned the field down to seven or eight, George Drake being first, Bill Holland and myself and Ned Drake next, Henry Lambton and Ned Harrison a little behind us, and I never saw any one else. At the Ham Green road the fox ran up the road a little way, the leading four couple flashed on and missed the turn, but the body hunted the line through. I did not get them to- 
gether till we got to the Luggarshall road. Here 'Ransome' made a drive up the furrow of a ploughed field (only the second we had seen), and then stopped as if she was shot. The fox had been headed by a plough and turned and shot to the left. 'Nosegay,' 'Governess' and one other hunted the line, and I nicked in with the body in the field before them, and away they scored again. They ran up the Luggarshall and Piddington road for the length of two fields. The fox was headed and turned down to the right, 'Gallant' making a good hit. The fox then shifted one furrow, 'Dreadnought,' another young one, hitting that off. Twice the fox tried to make his point at Piddington village, but both times was headed by hedge-cutters, but he tried it a field further on, and then turned up again and set his head for Muswell Hill. In the turn the body ran over it, but 'Nosegay' carried it on and never left the line. When we crossed the Piddington and Luggarshall road the second time, two or three horsemen joined, but I had no time to see who they were, two Drakes, Holland and I having the best of it. When about half-way up the hill the hounds paused among some cattle, but 'Blossom,' 'Governess' and two others hunted it through. When they got to the top, hounds turned short to the right, and I lost sight of them for two fields. The hill is very steep, and I got into a very deep stubble field, so I pulled to a trot to ease my horse. I went through a farm-yard, when I found myself again in the field with the hounds, and above them, they having gone down the hill, Ned Drake 
and Holland with them. George Drake had followed me through the farm-yard and then joined the other two. I kept above them. We then crossed the Brill and Bicester road, which only has two or three practical places. I got one above the hounds, and the others had to go to the bottom of the hill. I was still one field above the hounds when they turned sharp to the left, and came up the hill to me, and I was able to stand still for a few minutes, much to the advantage of my horse. Here Tom Lowndes came to me, but we had not much time to spare. They streamed down the hill as if for Boarstall Wood, but when they got to the road, turned away from it along the road for 200 yards, 'Blossom' and 'Governess' hunting it beautifully, and again over a little brook and up to Arncot Little Wood. Here the fox ran through a sheep-fold, and was only one field before us, down the rack way through the cut part of the wood, then down the outside on to Arncot Great Wood, where he went into the ride through the gate-one hour and seven minutes without a check to this point-up the ride nearly to the top, two Harrisons, Lambton, two Drakes, Lowndes, Holland and myself being then with them, and Mr. Brown of Piddington joined us as we crossed his farm; then through the top part and away over the hill, never having checked or divided, 'Governess' leading; then down the hill to the Arncot river, where they rather ran away from us. When we got to the Ambrosden road I thought he was going for the ruins, and went round by the road. However, on 
he went parallel to the Merton road, Brown and I on the road looking out for him to cross, and the others riding the line. At Ashley Bridge farm he turned short to the left, from the road and towards the farm, probably being headed, and as we turned into the field I expect he crossed the road-he was then two fields before us--hunted it on through a ploughed field, and he then crossed the road opposite the Merton earths, but passed them on to the village, crossed the road again, and ran down to the river side. Here we had our first check-one hour and thirty minutes to this point. Soon hit it off, and hunted him back towards the farm-house. Now comes the worst part of the story. Morris, my second whip, here came in sight on my left. About six couple of hounds had the line on the left side of a thick double hedge, the rest of the hounds being on the wrong side; just then Powell came up meeting us, with two couple of the hounds which had been left behind. He saw something move in the hedge, pulled his cap off, and capped the hounds on his side to a hare: "Be quiet," I shouted. In the meantime Morris had stopped the others off the line and got their heads up: There was a cur dog barking in the farm-yard, and three young hounds ran through the gate towards it from the other side, in front of those that had had the line. They had their heads up and started to join them, thinking there was a view. I got them all quiet as soon as I could, and drew every hedgerow round about for an hour, but could make no more of it. I got a line again over 
the road and up to the drain, and then away from it as if he had been headed, as there were two men working on the mouth of it almost, and I think since that he may perhaps have got in after all. At any rate it was the best run I ever saw, and if we had caught him, would have been perfection. I was riding 'Maximus,' Jack Darby's horse. He never made a mistake, and galloped the whole time with his head loose. He never was blown, and very little tired. Both he and I have a thorn in our knee, but that is all the grief we experienced.

"Come here and we will try and do it again."

One of my greatest friends was the Hon. Philip Pierrepoint, brother of Lord Manvers. On meeting him one day at Dick Paynter's, the horse-dealer in Bicester, he said, "Get up on this horse, and tell me if you like him". After galloping round the field I stopped and said, "I like him very well". He said, "Very well, I'll make you a present of him," and he gave Paynter $£_{120}$ for him. He afterwards said to me, "I couldn't subscribe more to you than I did to Mr. Drake, but I wish to give you a little bit extra".

He told me the following story of his brother: Lord Manvers wished to cross Oxford Street at the Marble Arch during the height of the season. After standing some time a milkmaid came up with her pails. He said, "I say, my lass, will you take me across the street? I'll give you a shilling. They won't mind knocking over an old chap.like me, but they won't run over you and your pails." She looked at him for a moment, gave her pails a rattle, and 
said, "Come on," and away she went across the street, and he ran after her. On gaining the pavement at the other side he gave her a shilling and wished her "Good morning".

One day we ran through Tusmore nearly to Swift's house, and had lost our fox. Algernon Peyton ran out on his feet, with his arm in a sling, having had a cropper shortly before, and said, "I saw a fox go into the wood three-quarters of an hour ago," looking at his watch. I drew the hounds across where he told me, and a hound called "Vulcan" (by "Ravisher" out of "Vocal") spoke to it. Worked on into the wood, got a fresh start at the fox, and I forget if we got him or not.

The last day of the season they ran four hours and forty-five minutes, and killed a fox in the woods. On the way home some of the gentlemen asked me if I would hunt another day. I said, "If I do you must mount me," all my horses being in physic. Next morning I thought no more about it, when I was told that Mr. Randal had sent his chestnut horse for me, and that the gentlemen would be there at twelve. Meantime hounds had been fed. I drew thirteen couple of the lightest feeders, sent them out walking, and got all the field in to luncheon, and kept them there as long as possible. Went out about two, luckily drew many places blank; found in Fritwell Gorse at four o'clock; ran hard for one hour and ten minutes, and ran to ground under the Brackley road; bolted and killed it.

At the end of the season of 1857 there were a 
good many wild deer in Whittlebury Forest, and they were to be exterminated. The keepers had several bloodhounds with which they hunted them, and one foxhound bitch with a short tail, "Damsel," which came from the Holderness kennel, and was steady from foxes.

There was one black buck left, and I heard that they were to hunt him at the end of the season. I rode over from Stratton Audley. The field consisted of several keepers mounted on ponies, and Mr. Robert Oliver in his pony trap. Luke, one of the keepers, acted as huntsman. He was a first-rate hand, but addicted to gin.

The ground was hard as iron and the dust flying. The bloodhounds hunted every inch, and took their oaths to it, but the foxhound bitch made every hit, and did not say so much about it. After running about two hours all the keepers' ponies got tired, and I and Mr. Oliver were left alone. I was trotting up a road listening to the cry, a thick bullfinch on my right, when the stag jumped at a high gate, did not clear it, and tumbled head over heels on to the road in front of me. I thought he would never get up again, but he got on to his legs, and struggled on very slowly. A few fields further on in jumping a hedge I almost jumped on to him as he was running up the other side quite slowly. He ran on to the road into the ditch, just in front of Bob Oliver's carriage. His servant, a Yorkshire boy, jumped out of the carriage and ran and got hold of the deer. He turned round and said, “Maister, he's kicked me 
in the feace". By this time Luke and the hounds had arrived, and the buck was safely captured, and was kept for many years after in a paddock at Whittlebury.

I bought the foxhound "Damsel" for two sovs., brought her to Fife, and gave her to Sir Arthur Halkett to hunt roe-deer.

In 1902 John Horsey, of Dallington, in Northamptonshire, wrote :-

"Your remarks about the deer-hunting in Whittlebury Forest take me back to those days. They sold the last couple of bloodhounds in Northampton Market, when John Stevenson, a sporting wine merchant in Sheep Street, who, I fancy, had given up hunting before you had the hounds, bought one (the finest dog I ever saw; he stood about twentyeight inches) for five guineas. Stevenson used to ride a blood mare every Sunday afternoon past our house to Brixworth or one of the other villages north of Northampton to spend his evening with some friends. I always looked out for him about two o'clock, and then waited for the bloodhound. $\mathrm{He}$ was unchained about ten minutes later, and came on throwing his tongue in grand style, up the middle of the road. This went on for about two years. The dog trotted about the town, and was one of the sights of it, but he became old, bit a child and had to be put away. I have never seen another like him; no lumber or coarseness as most bloodhounds have."

Lord Southampton was at that time master of the Grafton country, and I often hunted with him. VOL. I. 
He hunted the hounds himself, had a good knowledge of where the fox went to, but never rode over a fence.

Hounds were wonderfully fond of him, but he had no action about him. I have seen him blow his horn by the side of a big fence when he wished to get the hounds to the other side, the hounds standing and looking up at him, when one wave of his arm would have sent them over it. His whipper-in, Bob Ward, was a capital man with hounds, a great long wiry chap, for many years afterwards huntsman to the Hertfordshire Hounds.

One day when running in the Wistley Wood, Bob met his lordship coming round a corner. "Where are the hounds, Bob?" says he. "All over the wood, my lord, looking for you," and without waiting for an answer dashed in among the bushes.

Lord Southampton was very short in the temper, and when things went wrong was very hard on his servants. If Bob blew his horn, he would say, "Put that penny trumpet away". He always walked slowly from covert to covert, and thereby lost a deal of time.

Major Burrowes, after giving up the Cottesmore Hounds, kept his horses at the Inn at Stowe, and hunted in the Crafton country. One day when hounds had run very hard, he and John Elliot, a leading man in that country, were alone with the hounds. When Lord Southampton got to them, he commenced blowing them up. Burrowes looked him 



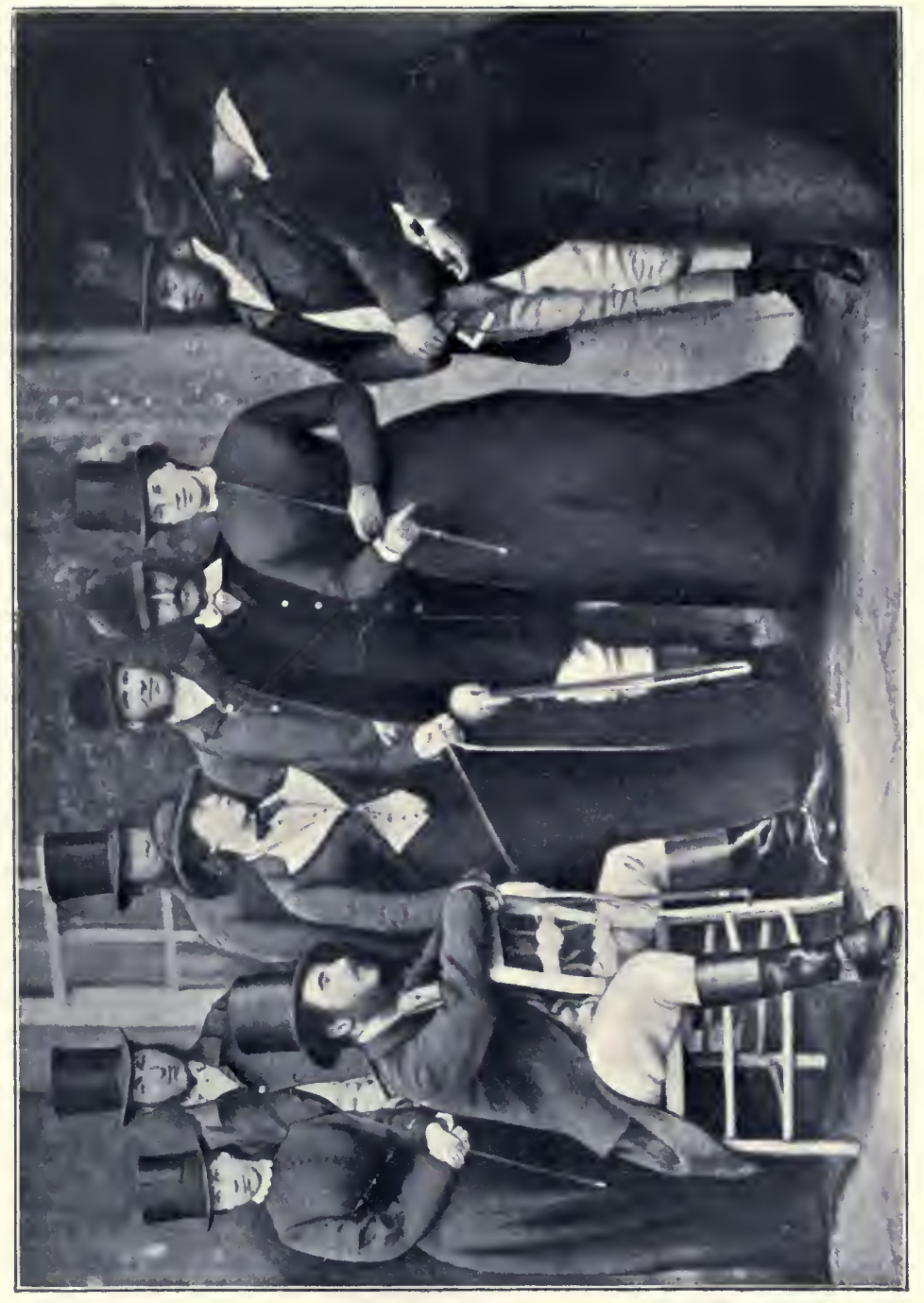

$c$

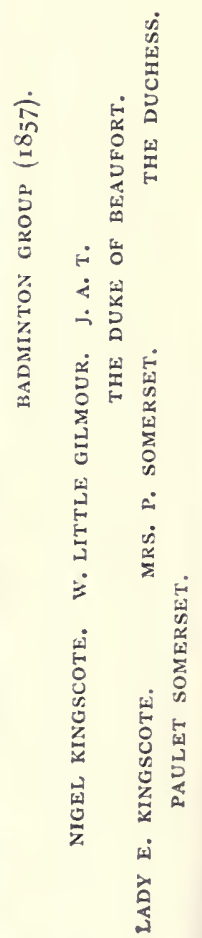


straight in the face and burst out laughing. "By God, sir, if you laugh I'll send the hounds home." This was too ridiculous, and as some of the field had by this time arrived, there was a universal roar!

One day when something had put him out, he sent the hounds home soon after two o'clock. On riding past him, Algernon Peyton said, "Good-night, my lord ". "Damn it, I ain't going to bed," was his reply.

At the end of the season of 1857 we took some horses and went to Badminton. The party in the house were the Duke and Duchess, Lady Emily and Nigel Kingscote, Paulet Somerset and his wife, Walter Little Gilmour, Ferdinand St. John, self and wife.

The Duke hunted the hounds himself. Will Stansby was kennel huntsman; Will Walker, first whip ; Jim Walker, second horseman. The Duke was a capital huntsman; wonderful quick eye, and knew the business well ; could gallop well, but would not jump. We had a very happy time there.

I had a brown horse called "O'Donnell," a wonderful timber jumper. He jumped gates standing. The Duchess offered me $£ 200$ for him, intending to make him a present to the Duke, but as he was advertised with the others to be sold at Tattersall's, I said she had better buy him there. She did so for, I think, $£ \mathrm{I} 60$. The hounds were sold in the kennels at Stratton Audley, and fetched $£ \mathrm{I}, 008$. 
Jack Morgan bought about twenty-five couple for the South Wold country. Yorke Dallas and "Trotting "Fox were the masters. I took them out the next day to let him see them in work. Had a good day, and had a fox ready to catch, but I had to leave them to attend a dinner that day in Bicester. I galloped all the way, about twelve miles, and when I got to the town heard something patter behind me, looked back, and saw "Delicate" had run away from the men and followed me all the way.

The horses were sold at Tattersall's. I had a capital sale. "Maximus" fetched $£_{560}$; "Peter the Great," $£_{280}$; "Inkerman," £ 183 ; " Esparto," $£$ 194; "O'Donnell," $£$ I68. In all twenty-one horses - total, $£ 2,486$. "Highlander" was not sold, as he had a big hock. "Abbess" was not sold; I took her to Fife, and afterwards sold her to George Dempster of Dunnichen. "Patience" was sold to Mr. Gammie at Shotover. I knew she would be of no use to him, and he promised to let me have her back; but he sold her to Lord Macclesfield. $\mathrm{He}$ bred from her, and I bought a son of hers when I was at Brixworth-a very fine horse, but queer tempered like herself. Tom Firr used to ride him. He was taken ill after a hard day and died before we could get him home.

At this time the present Four-in-Hand Club was started, Will Morritt being one of the most enthusiastic members. The Duke of Beaufort asked me if I would like to be a member, so I was elected. 


\section{Rules of the Four-in-Hand Driving Club.}

I. That this club be called the Four-in-Hand Driving Club.

2. That the club be limited to twenty-six members.

3. That the committee consist of president, vicepresident, three members and two secretaries.

4. That the committee alone have power in the election of members, and in all other matters connected with the club.

5. That during the season two days at least be appointed for a meeting of the coaches, to drive down to some place for dinner.

6. That Wednesday be considered a club day.

7. That any person being absent from the club during a whole year cease to be a member.

8. That five form a quorum of the committee.

Committee.-Duke of Beaufort, President; Marquis of Stafford, Vice-President ; Earl Vane, Captain Baillie, Royal Horse Guards ; W. Morritt ; J. Baldwin and L. Agar Ellis, Secretaries.

\section{Driving Rules to be Observed on Club Days.}

I. That no coach be permitted to pass another, unless the latter be standing still, or permission has been obtained.

2. The general pace not to exceed ten miles an hour.

3. The order of starting to be arranged by lot.

4. The starting point within the gate at Hyde Park Corner. The hour 4.45 P.M. 
Members.-Duke of Beaufort, Marquis of Stafford, Earl Vane, Lord Edward Thynne, Lord Henry Thynne, Sir Watkin W. Wynn, W. Morritt, C. Leslie, Captain Baillie, Royal Horse Guards; W. Couper, W. Craven, Ist Life Guards ; W. P. Thornhill, J. T. Jones, Royal Horse Guards ; J. L. Baldwin, L. Agar Ellis, Lord Willoughby de Broke, Lord Strathmore, Lord Chesterfield, Sir W. Carew, A. R. Hughes, J. Lyon, 2nd Life Guards; Lord Burghersh, F. Maguinis, Sir M. S. Stewart, J. Anstruther Thomson.

I bought four little brown horses-"Contract," "Creeper," "Cameron" and "Cracker"-and Martin Corry ("Spicy Bill") lent me his coach, which he always left at the coachmaker's in London.

"Dysart House, 2 Ist September, I857.

"My Dear Mrs. Thomson,-

"I cannot resist sending you the accompanying letter. The conquest of Pierrepoint is not a new triumph, I am aware-even his 'old woman' knew him to be the humblest and most admiring of your slaves; but, as we all, like Surface in the 'School for Scandal,' when we go leave our characters behind us, it is agreeable to know the impression we have made and what is said of us behind our backs; and it must be gratifying to you and your 'young man' to know how much you are missed, and how much your absence is deplored. I only fear that anything we can do to make Fife bearable will be less availing than it otherwise might have been. 
"If Jack has not started when you get this pray tell him that the hounds leave the kennels at half-past eight, and that Mr. Harvey's horse shall join his, and stay with them.

"Yours faithfully,

$$
\begin{aligned}
& \text { "Rosslyn." } \\
& \text { "Evenley Hall, Brackley, } \\
& \text { "Igth September, I857. }
\end{aligned}
$$

"My Dear Rosslyn,-

"Your letter (only) reached me yesterday, and I did not reply by return of post, for, through this house being full of guests, I could not go over to Oxford yet, as I was engaged to go to Bicester, and I thought that when there I might possibly get you some account of S.'s ' black mare,' ' from information that I received' (as policemen say). I do not think the black mare would be likely to suit you, and I do not think my friend C.S. would be at all a safe card to play 'unsight, unseen' with-at least I should be loathe to trust him. I wish I could help you to a nag, such as you describe, but, alas, I know of none.

"I regret that your harvest is so much hindered. We have had heavy rains here, but as the corn was nearly housed, and grass kept getting short, it was a great boon to us. Our potatoes have got the smallpox, and I fear it is spreading.

"Pray remember me most kindly to Jack Thomson and his handsome wife. 'We ne'er shall look upon their like again' in this country, for she was the 


\section{best-looking woman in the country, and he the best man with hounds that ever went over it. \\ "Good-bye, \\ "Yours ever and truly, \\ "P. Pierrepoint.}

"My old woman sends you her kind remems."

\section{BICESTER ALPHABET.}

A stands for Algey Peyton-he's Joint-Master of our HoundsAnd when I speak of him I keep my pen in proper bounds; For hard as is my heart, sir, it would really make it bleed, To lampoon so good a fellow who came forward in our need.

B stands for Mr. Burton, who in Ireland was a jewel!Before he came to England how I wish he'd got his gruel ! $\mathrm{He}$ may be as wise as Solon, but in his knowledge box I'm blessed if he's the science of the hunting of the fox.

C next, which stands for Clayton-he's "the uncle of the Drakes"Who when he jumps a molehill, a mountain of it makes; And talks of timber "six foot six" and " nipping over stiles"-More than half of which performance in his fertile fancy lies.

D stands for all the Drakes, sir, and in truth they all can rideYou'll not find it easy sailing with "the Admiral " 'longside ; And I doubt if in all England any hunting-field can dish up Such a "broth of boys" in pigskin as the one they call "the Bishop".

$\mathrm{E}$ is the Earl of Effingham, and here, hold hard, my muse, Of the upper ten he's one whom e'en Bright could not abuse;

So remember that the copy-book in which you learnt these letters Taught you "never to presume to speak unkindly of your betters".

F stands for Harvie Farquhar, who fancies he's got hands, Because a wretched three-year-old he o'er a hurdle lands!True Banker he! - for troth to see ('tis as good as any play) Him when there's an important check he's always in the way.

G stands for little Gipps-if he'd been here long enough

I've no doubt I should find something that would make him cut up rough ;

And I'm told that with his swagger he astonishes the noodles

Who sit in the bay window in the club that they call "Boodles". 
$H$ stands for Colonel Hunt-a real customer is he, Who o'er the fences flying 'tis a pleasure for to see; Whether mixed up nice or nasty, he takes them as they come, Nor looks into particulars about the crust or crumb.

I next, which stands for Iveson-a good but dullish dog, Who blushes like a maiden, but snorts like any hog When his friends at Bicester get him down, and mercilessly poke Their knuckles in his ribs, the which he doesn't think a joke.

Now K it stands for Kapital, and in the "categories" Are Barrington and Lambton and other "chers amis" Who for reasons one or other I don't put in my song, And, besides, to name them all would make my alphabet too long.

L stands for Little Lambton (he's been mentioned just above), And M stands for Mackenzie, who I'm sure's been crossed in love; When you see his doleful visage the impression that it leaves Is surely that Mackenzie, sir, must be "Mackenzie Greaves".

M also stands for Marsham, all whiskers and moustacheIf mine were half as lanky I should use "Myrifik Starch"; He looks bold as a lion, but I'm sure you'll all agree, That Bullock's heart inside it is no bigger than a pea.

$\mathrm{N}$-now $\mathrm{N}$ shall be Ned Harrison-no neddy man is he, Though crashing past on thirty pounds your swell on hundreds three ;

For well he knows, where'er he goes, no risk attends his lotLife's not at stake, for he can't break-a neck he hasn't got.

O in Pytchley stands for Opetown, whose lady is so stout! And $\mathrm{P}$ is for the Post-boy who pilots her about; But here there ain't no genuine $O$ to bring into my verses, And I cannot clip my "H's," than bad English nothing worse is.

P stands for Philip Pierrepoint, who's forgotten more than " $Q$ "That's Quartermain, or Anderson or Symonds ever knew ; I don't quite skip the letter if you'll take the cue from me, But in all the country round about the deil a "Q" I see.

Then $T$ is the Taylor who killed a cow, they say, Because to his orchard came to pick a bit of hay; In a cherry-stealing urchin, too, a brace of slugs he put, And also shot a horse because he trod upon his foot. 
$\mathrm{U}$ as a patronymic here to me's unknown to fame, Though as to $\mathrm{V}$ in Verisofts we've plenty of that name ; But their real appellation here I will not now intrude, Lest they should think the dotting of the i's a little rude.

Next X it stands for Xcellent-my poetry I meanThough I fear you'll think your poet has a nasty touch of spleen ; And $\mathrm{Y}$ it is the yearning to hold this looking-glass In the faces of all the $Z$ anies as before it each doth pass.

Written by Harvie Farquhar, I think.-J. A. T. 



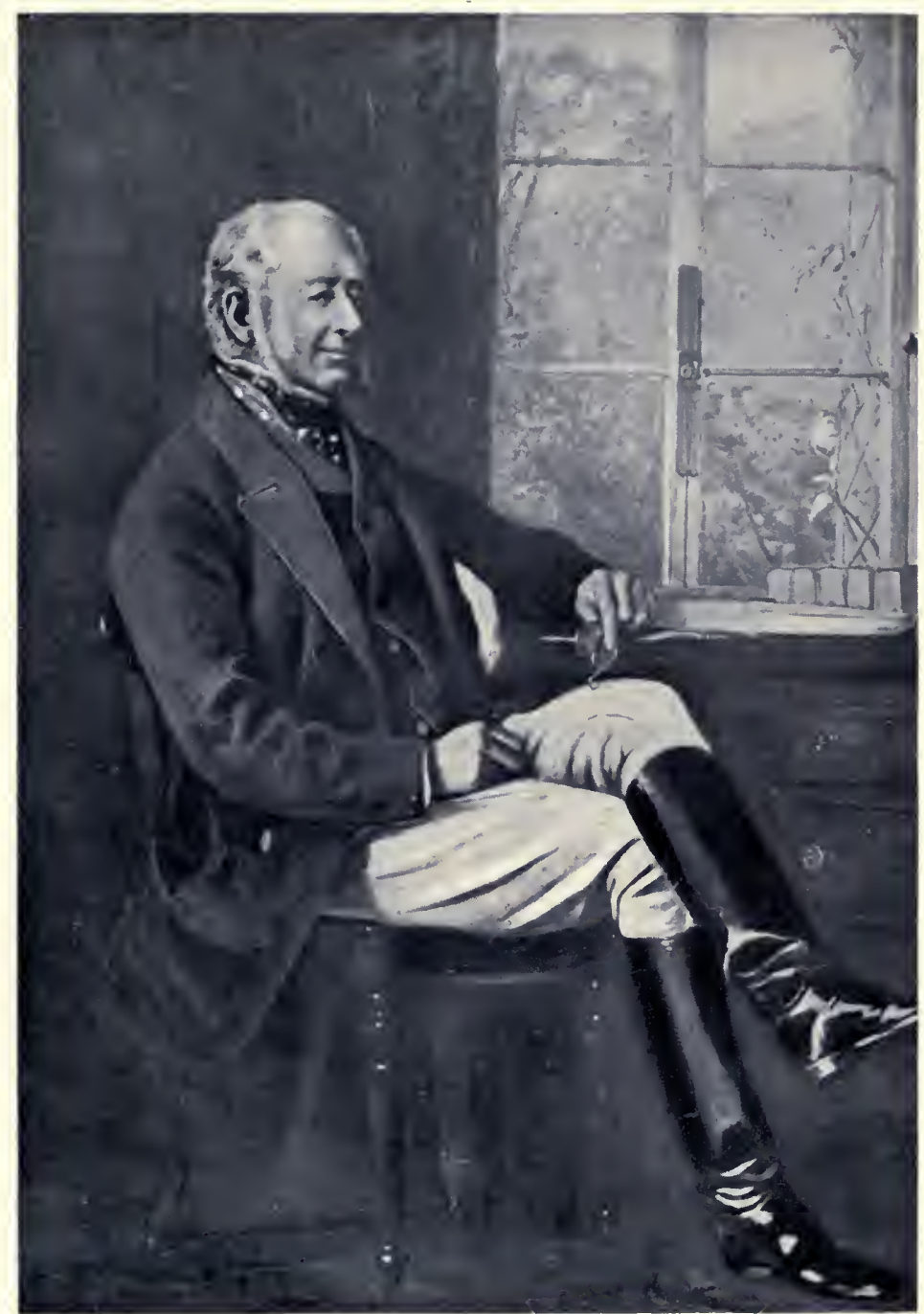

JAMES, 3RD EARL OF ROSSLYN.

From a Painting at Dysart. 


\section{CHAPTER XIV.}

FIFE.

HAving settled all my affairs at Bicester I got home to Charleton on Ist July, I857.

Lord Rosslyn was Master of the Fife Hounds ; Oxtoby, huntsman; Fred Turpin, first whip; Stephen Dobson, second.

Oxtoby was very unwell, and Turpin hunted the hounds most of the season, and I whipped-in to him. At the end of the season Oxtoby went to live at Ollerton, and rode Percy Williams' second horse; but he died soon after of consumption. He was a most respectable, good man and a capital breaker of hounds, but too tame for this country, and never was in good health.

First hunting day was. Melville Woods, at 9.30; thirty-four couple hounds. Found two cubs and two old foxes; killed a cub in the middle of the wood; could do no good with the others. Went to "Nottingham" covert; chopped a cub and ran two to ground. Felton Hervey was staying with me; he rode "Charm" and I rode "Contract". Rosslyn, Patterson, Balfour and Haig out.

As so many foxes were destroyed every year on the Links, I rented all the rabbits between Largo 
and Elie, and paid the following rents: Kinnear, $£ 35$; Wood, $£_{30}$; Fortune, £40; Luke, £30total, $£$ I 35 . I employed five men besides Corbett, my gamekeeper, who had charge.

I took Sir James Burnett's house, I3 Moray Place, and went there about the end of October.

In October, I857, while I was staying in Edinburgh, the keeper at Killala got a vixen fox in a trap. It lost one of its fore-feet. I took it to Edinburgh and kept it in the area for some days, then took it to Charleton, and put it into an empty stable. It got out the first night.

In spring there was a vixen fox on the hill with a white breast and white pads; she had five cubs. About the beginning of May the lame vixen came, followed by four cubs. They all lived together and appeared to suckle indiscriminately. We could see them with a telescope from the back windows of the house. The lame vixen always went out to forage and the other one sat on the top of the rock on sentry. The white vixen unfortunately got into a trap in Balcarres Den. Some carters found her on the side of the road, and in catching her with a cartrope, strangled her. The lame one was no more seen.

One day in the west of Fife, Andrew Gullane asked Lord Rosslyn to draw a patch of gorse on the side of a hill. Rosslyn said, "It is no use, we might find a mouse". The hounds were put in, and out bounced a great big fox. Gullane galloped away after the hounds shouting out, "A muckle big moose, my lord, a muckle big moose!" 
I used to hunt as much as possible in Fife and return to Edinburgh in the evening. We got back to Charleton about the end of January, 1858 .

The following account of a run appeared in $T$ The Field about this time :-

" 3 Ist December, I 857.--Met at Chárleton, where a large field had assembled, the day being very fine. Drew Balcarres Craig; found a fox directly, and after a sharp burst of fifteen minutes, killed in Balneil Den. Tried Belliston, which proved blank. Rode on to Lathockar, where one of the right sort was viewed away running northwards by Gilmerton through Lambieletham cover to Carngour Wood, where he was headed; back again through Carngour and Brigton. The next four miles were across grass land enclosed by stone walls. The pace was now a rattling one. Those who were able to live with the hounds will not soon forget the last day of the year I857. Through Kinaldy Den to Upper Kinaldy, Pitarthy and Upper Carnbee, over Kelly Law, pointing towards the Free Kirk at Arncroach; doubled back into the cover at Kettlenaked, but did not tarry long there; continued eastward past Gordonshall. Here hounds began to run in view through Firthfield to Airdrie, where this game fox was run into in gallant style. Time, one hour and eighteen minutes; the distance not less than thirteen miles. Mr. Anstruther Thomson as usual had much the best of it for the first few miles, but 'Highlander' was short of work and too fat for the pace, and Mr. WhyteMelville, Mr. Hervey, Sir T. Erskine, Mr. Clark 
and Mr. Williamson had the best of most of it. The noble Master and his son were in the front rank for the last three miles. Fred Turpin, first whip, hunted the hounds with much determination and skill, though we regretted the absence of Oxtoby, our huntsman, to whom the credit is due for the admirable appearance and condition of the hounds."

I went to Morrell's sale on I 4 th April. Hounds fetched $£ 2,600$. Duke of Beaufort bought "Spangle" and some of the best of them, and engaged Tom Clark as huntsman. There was a black dog called "Hercules," bred by Sir R. Sutton; he was a good deal thought of. Charles Payne chucked him under the chin with the handle of his hunting whip, and said he was "a bad-shouldered beggar". There was a tremendous company assembled-they said sixty Masters of Hounds-and many huntsmen.

Hunted one day with Lord Southampton at Silverstone; stayed a night at Whittlebury. I then went a round of visits-Kirkington, Sir C. Dashwood's ; Caverfield, Dr. Marsham's; Swift's House, Sir H. Peyton's ; Mancetter, R. Harper's ; Hoarcross, Hugo Meynell's; Rufford, Percy Williams ; Osberton, George Foljambe; and got home again on the 27 th.

Ist May, I858.-Commenced partnership with Rosslyn. I was to hunt hounds; Turpin and Stephen Dobson, whips. Hunt horses to be joint property, and expenses over subscription to be divided.

Ioth June.-Rarey came to Edinburgh. We 
were sworn to secrecy and paid ten guineas each ; Duke of Athol and Baker, the African traveller, among the pupils. When the lecture commenced I ventured to ask Mr. Rarey how he caught the horse before he put the strap on him. He said, "It is no use talking to a boy if he can't hear you, or to a horse on a prairie, you must get him into a compound".

John Waite, Lord Rothes' groom, brought over a pony which would not be clipped. Rarey laid it down, but it never ceased to kick when it heard the clip of the scissors. I returned in the steam-boat with Waite. He had had a glass and was very proud of having "licked Rarey".

Rarey was the bravest man I ever saw. He would let a horse kick close to his head without ever winking. He was a good horse-tamer, but no horseman. Sir George Chetwynd had him at Grendon, and mounted him with the Atherstone. Hounds, but he was no use out hunting.

On the 7 th June I went to Trinity Muir Fair at Brechin. Met Adam Thomson (the laird) showing a horse to some young gentlemen. He whispered me, "Make a bid for this horse, and I know these gents will buy it". I said, "You be d-d, I didn't come here to tout for you". He took off his hat, made a low bow, and said, "Thank you, sir, I am very sorry I cannot accept your offer".

2nd September.-Went to the Highland Society Show at Aberdeen. It rained in torrents the whole time.

Ioth September.-Went to Osberton for Don- 
caster Races. Went out cub-hunting at Carleton Bottom with Dick Lumley (afterwards Lord Scarborough), Master of Grove Hounds; drove to the meet with George Foljambe and Charlie Wicksted - the very best of company. Bought a lot of Cinnamon turkeys, which I gave to the farmer's wife at Kippo in Fife to replace damage done by the foxes.

I 8th September, 1858. - Commenced hunting Melville Wood; caught a cub. Hounds rather slack about eating foxes; got over that by holding on to the fox and letting the terriers loose.

Lady Rosslyn died 3oth September, and was buried at Rosslyn Chapel on 6th October. She was the sister of Admiral Wemyss.

$2^{\text {th }}$ October.-First regular day. Wemyss Castle.

I $5^{\text {th }}$ November.-Turpin got a fall on "Crocodile" and a kick on the head. I found him lying on the sofa at the New Inn, and asked him what the doctor had said. "He said it was a looky job I had such a thick skool," was his answer. Next day his head was as big as two, but he came out all the same. 2oth December.--Galloping across the moor in the dark, back of Newburn, "Crocodile" turned heels over head, gave me a clip on my head and landed with his head doubled under him, his feet through the reins, and his hind foot in my cap. Luckily the ground was soft.

5th January; I 859.- Had a capital run. Found at large covert at Lathockar. A wild, windy morning: Ran to Lingo and then back to the covert 
away to the east through Kinaldy and back to Lingo. Many hounds got caught in snares. Got on another fox in Lathockar, away over the grass past Cassingray to Belleston, through the covert without a check past Gibliston and East Pitcorthie to Sandriggs; down to Newark, where he ran along the shore close to the sea; to Ardross through the farm-yard there; round east side of Kilconquhar Loch, past Muircambus, turned to the right over the Colinsbro Acres and up the hill, and got into the made earth on Reres Craig-a real good run. Got him out, much to the disgust of old Corbett, my keeper.

I 7 th March.-I and Stephen went to Bramham to get some young hounds. The best of them was "Ringwood," a blue dog rather above the Bramham size. George Fox mounted us both, and we had a hunt with Charles Treadwell.

2 Ist March, i859.- - Ran a fox over the hill at Cults. I was close to the hounds, and when I got to the edge of the hill there was nothing to be seen. I got down to the road and got their spoor in the mud into the lime working. They ran hard in the galleries for twenty minutes. The galleries are all at right angles. When the fox turned, the hounds overran it, and there was silence. At the next corner they got the scent again, and such a crash of music! The miners came with their lamps and we all ran on foot. At last the fox got among some stones near the roof, where we could see him, but we dare not move the stones for fear of letting the roof down, so had to leave him.

VOL. I. 
In 1859 Lord Rosslyn was appointed UnderSecretary for War under General Peel, and went to live in London. I went on as sole Master.

The season ended on 19th April. Hunted eighty-five days; killed twenty brace; thirteen to ground.

The Hunt Meeting Committee paid off balance of debt, leaving debt of $£ 500$; the interest to be paid from subscription.

On I $3^{\text {th }}$ April, I859, the sale of the Rufford Hounds took place. Sir David Baird and Alec Kinloch bought four couple, which they lent to me. Hay Wemyss lent us Torry House and sent the key of the cellar. Bob Cathcart, Percy Williams, Alec Kinloch, David Baird and myself were the party.

On the r8th ran a fox to ground in a coal-waste near Pitfirrane. Five hounds had gone in, and I was just in time to catch "Tempest" by her tail. The hole was about two and a half feet in diameter. While we were standing round pondering what to do, a skinny, ragged boy took a bit of candle out of his pocket and some lucifer matches and wobbled into the hole feet foremost. He stayed away about forty minutes, and we never expected to see him again, and were truly glad when he reappeared, very tired and covered with mud. I said, "Where have you been ?" "Ower yonder," pointing at a tree on the other side of the field. "And what is it like?" "High as the trees in pairts, and ye ha'e to gang on hands and knees whiles!" "Did you see the hounds?" 
"The candle went out with the black damp. They had got the tod in a hole in the side, and I could fin' their breeth, and they pu'ed a' the 'oo aff him." By this time the bystanders, principally miners, had become very brave, and four of them volunteered to go in with a spade. On their return they said the candle began to grow dim with the black damp. Two of them remained with the candle, the other two going on in the dark. They brought out the hounds, but not the fox. They said a dead fox, dead a long time, was lying in the mine. A hunted fox might perhaps die of suffocation on getting into black damp.

On the 2oth I tumbled into the Pow Burn with "Mutineer," and was very bad with rheumatism.

Met at Dron, 5th May, last day. The hounds were like drums with eating dead sheep, the hills being covered with them, so we had to go home.

Seventy-five hunting days, two blank days, frost thirty-one days, killed twenty-three brace, to ground seventeen brace.

Stephen Dobson left and went as first whip to the Rufford Hounds.

In May, Lord Loughborough stood for the county of Fife, and was opposed by Mr. Wemyss. I undertook to arrange for carriages for the conveyance of voters, and was assisted by Alec Kinloch. Account annexed. I mention this to show that the proceedings in those days were very different from the rules for elections of the present day (1902). 
Captain Thomson of Charleton.

To Scotr, Croall, \& Co., Job and Post Masters, I 859 .

Royal Horse Bazaar and 83 Rose Street, Edinburgh.

May 3rd. To 28 Carriages and pairs of Horses for the

County of Fife Election-3 days at

$£ 2$ 2s. each per day . . . . $£$ I 768 o

" " 20 Broughams and one horse for 20

Broughams -3 days at $£$ I i Is. 6 d. each per day

$" \quad " \quad 48$ Coachmen -3 days at 5 s. each per

day . . . . . . 3600

" " " Expenses for Hotel Bills, Tolls, etc.

" " " Horse and Gig to Dysart Toll Bar

"Expenses for Freight Tolls, Horse and

Man

Wemyss was elected with a majority of 237 .

In June, I859, the Duke of Beaufort and Lord Winchelsea made a match-hounds against racehorses. The Duke backed hounds. He got a man from Cumberland with a trail hound to train the hounds. The trail hound was high on leg, light of bone, with a sharp nose, light coloured, and rather like a collie. The man was rather offended with me because I asked if his dog was a foxhound.

I went to Badminton on 26th June when they were training the hounds. The training ground was two miles from Worcester Lodge to the house at Badminton. Four of us were mounted and stationed half a mile apart. I had the last half-mile, and as soon as I saw they had started I set off and got half through my distance before they overtook me. The 
old dog was going like an arrow, with his head poked out ; the hounds were flashing about and not running seriously; some of them would gallop past him and then come back behind him. The scent was so strong that I could wind it on horseback. The trainer was at the winning post, and when the old dog arrived he rammed his head into a pot full of feed. The match did not come off in consequence of the illness or death of some relation.

Season began I 2th September. I again took Sir James Burnett's house. A boy, William, was born there on 6th September-Lord Loughborough, godfather. 
CHAPTER XV.

- THE FIFE MOUNTED RIFLES.

OnE evening in March, I860, a party of gentlemen were assembled in the smoking-room at Dysart House. One of them read an extract from a newspaper stating that the Duke of Manchester had appeared at a recent levée in the uniform of a volunteer regiment of Mounted Rifles. Lord Loughborough said, "Why should we not have a cavalry regiment in Fife?" and, turning to me, asked if I would undertake it. I replied, "If you will give me something to start upon-a requisition with a sufficient number of names." A paper was at once drawn up and afterwards handed round in the hunting-field, and very soon I I names were on the list.

On the 24th of March a dinner was given to Lord Loughborough at Kirkcaldy by the Conservative electors of Fife, and attended by about 400 gentlemen. After the usual toasts I proposed the health of "The Tenantry of Fife," and said: "I am very grateful to the chairman for allowing me the privilege of proposing this toast. Few landlords in Fife, I believe, enjoy the privilege of so extensive a circle of personal acquaintances among that body as I do, and amongst the tenantry of Fife are many 
whom I am not only glad to meet as acquaintances, but am proud to call my intimate friends. ... A Around me I see a body of men, in appearance, manly, intelligent and gentlemanlike; in manner, frank, kindly and courteous; in conversation, sensible, shrewd and well-educated. If we follow them to their homes we find these men in their professional employments active and industrious, pursuing the practice of agriculture with skill and diligence, turning to account every art of science and chemistry to increase the produce of the soil. By their energy and enterprise we find swamps drained, hills levelled, the course of rivers altered, the whole face of the country changed. We find waving crops where only rushes flourished; we find lowing herds on lands which before were the resting-place of the snipe and the plover; we find two blades of corn where only one grew before; and any man who can achieve such a result is a benefactor to his country. In matters of business we find these men liberal, honest and straightforward. In their domestic circles we find them contented, happy and hospitable, ready ever to lend a helping hand to the poor, ever ready to 'welcome the coming, and speed the parting guest'. We find among them every quality which can adorn the character of an honest man, and we as a county have especial reason to be proud of the tenantry of Fife. In their political opinions, of course, we find men of every shade of opinion; many of whom, although they differ from us, are entitled to our respect; but I think I am not far 
wrong when I say that the tenantry of Fife are a Conservative body, anxious to preserve that which is good, willing to accept of judicious improvements and advances, but not carried away by every cry for reform, not rushing after every change for change's sake. We find the tenantry of Fife manfully and moderately maintaining their political opinions, and expressing those opinions with an eloquence worthy even of the senate. Not only in more important matters, but in every recreation and sport we find our tenantry take a leading part-not neglecting their business, but partaking with moderation and in a proper manner in those amusements which the country affords. Some we find on the Links at St. Andrews, competing at our national game of golf, and not only competing but carrying off the highest prizes from competitors from every part of the kingdom. Others take the lead and 'bear the bell' at the 'roaring game' so dear to all keen curlers, whom I may congratulate on the extraordinary severity of this season. Others again gallantly gallop after the Fife Fox Hounds, and with characteristic boldness clear every obstacle in their stride. Even those who do not join in this glorious sport aid us with their countenance and assistance; and gladly do I take this opportunity of thanking them for the liberality with which they permit the Fife Fox Hounds to roam over their fields. I trust we shall soon see the tenantry of Fife in a new character, and find them riding in the ranks of the Fife Mounted Rifle Volunteers, and that we shall find that 
those who now ride foremost in the chase are ready to ride foremost in the defence of their country. I am happy to inform those gentlemen who have already enrolled their names that the offer of their services was forwarded to the Lord-Lieutenant some days ago, and that we may hope for a speedy reply. It is only one short week since the movement commenced, and the list, which I now hold in my hand, contains ninety-seven names. Some exception has been taken to this corps on the plea that it was raised in an exclusive spirit. This I totally and entirely deny. We are willing to take any man, of any rank, religion or politics, the only qualification being, that he is willing to equip himself, and is in possession of a horse suitable for the purpose. Again, it has been said that it takes away the best men from the other corps. It might do so if they belonged to any other corps. It happens, however, that most of those who joined the mounted corps do not belong to any other corps, from particular circumstances, and in many instances in consequence of their residences being at a distance from the headquarters of the companies. But, even if we did take away two or three men from each of the fifteen corps that exist in the county, I think we should not detract very much from their efficiency, and certainly. should add very much to our own. The only object in raising this force was to obtain the services of those who could not serve in any other corps, and to provide for a branch of the service which appears to me to have been too much overlooked in the volunteer movement. 
"I had the honour of serving Her Majesty for some years in a cavalry regiment-a regiment which any man may be proud to belong to-I mean the 9th Lancers-that gallant regiment whose exploits in the late Indian War all are conversant with, and which has been aptly described as the pattern of a cavalry regiment-that regiment which, on leaving India, received the unusual honour of 'an order in Council' and a 'general salute'. That regiment gained its laurels under the same system, and under the same regulations which were put in practice by its late commanding officer, and it will be gratifying to you to know that its commanding officer is a Fife man, and now sits among you-I mean the Earl of Rosslyn. Whatever habits of discipline and obedience I learned were acquired under his tuition. Although my services were of short duration, and in time of peace, I believe I did attain some practical knowledge of my profession and of the necessary qualifications of a mounted dragoon ; and, from the specimens both of men and horses with which I am personally acquainted among those who have enrolled themselves, I can confidently state that they are of the right material. It is very encouraging to see the warm interest which this movement excites among the elder portion of the community. I am sure the thoughts of many a bold yeoman recurred to former times when he sat in the saddle and rode in the ranks of the Fife Yeomanry Cavalry when they had the honour of being reviewed by his gracious Majesty George IV. I am happy to 
see one worthy gentleman among us who, I know, performed a conspicuous part on that occasion, and who retains in his possession the identical pair of boots which he wore on that day as a memento of the occasion-Mr. Hall Pringle. My earliest recollections are connected with the Fife Yeomanry, and the most-valued heir-loom which I possess is a piece of plate presented by the 'Fife Yeomanry Cavalry' to my father as a testimony of their regard and esteem during the many years which he commanded the regiment. I fondly hope that this regiment, now in its infancy, may succeed, and flourish, and rival its predecessor; that we may prove ourselves worthy sons of worthy fathers; and that we are not inferior to them either in spirit or efficiency. I now beg you to fill a bumper to 'the tenantry of Fife,' and beg to couple with that toast the name of Mr. Peter Kininmonth. Long may the present mutual good feeling exist between landlord and tenant. Long may our people be prosperous and our country at peace; but if the time should come when an invader dares to show himself on our coast, then let both landlords and tenants ride side by side in the ranks of the 'Fife Mounted Volunteer Corps,' joining with the riflemen of our cities and the artillerymen of our coasts, forming a combination such as no other country can boast of, animated with one spirit, and ready to fight to the death in defence of our country and 'oor ain firesides'."

When it was settled that the royal review was to take place in Scotland on 7 th August, I860, Lord 
Rosslyn wrote saying that if the regiment was ever to be embodied it must appear at the review. At that time patterns, etc., were all settled, but the regiment had not a stitch of clothing, no horse appointments, and, with the exception of the St. Andrews troop, had not attended a mounted parade.

The next thing was to make inquiry for an adjutant. Sir Arthur Halkett said, "Crabtree is the man". Captain Crabtree had served many years in the 3 rd Hussars, had been acting adjutant, acting riding-master and quartermaster, and had seen much service in India. Sir Arthur was desired to write to him, and Captain Crabtree's reply was his appearing at Charleton next day. "I have come in case I can be of any assistance to you."

It was only eleven days till the day of the review. All the tailors and bootmakers in the county were set to work, and worked with a will.

The following telegram was sent to Hill Bowen, a saddler at Walsall: "Spurs and leathers, headcollars, chains, saddle-cloths-six dozen of each. Can they be delivered in Edinburgh on Saturday, $4^{\text {th }}$ August? Telegraph answer. Letter sent by post.-J. A. Thomson." He replied they should be ready on Monday by the middle of the day.

The regiment was much indebted to Mr. Chiene, then residing at Lundin House, father of the present eminent surgeon, who was at that time a private in the Cupar troop. There being a difficulty in getting cloaks made in Fife, Mr. Chiene went to Edinburgh, 
made an arrangement with a wholesale house, and produced the number required within the proper time.

"Battalion Order by Major the Earl of Rosslyn, COMMANDING F.M.R.V.

$$
\text { "Cupar, } 4^{\text {th }} \text { August, } 1860 .
$$

" On Monday morning the troops will proceed to Edinburgh to attend the review on the 7 th inst. Officers commanding troops will issue the necessary order for conveyance of their respective troops."

In Colonel Thomson's own words :-

"We proceeded to Edinburgh on Monday, 6th August, crossing from Burntisland in the goods boat, which will hold about a hundred horses formed around the decks with their heads inwards, each man at his horse's head. We had plain saddles and bridles and spurs.

" The following telegram arrived: 'From Hill Bowen, Pleck, Walsall, to Captain A. Thomson, Cupar-Fife, near Edinburgh.-We are packing the basket. Shall come this night certain with every article myself.'

"In spite of Hill Bowen's telegram, the goods had not arrived by the middle of the day. Captain Crabtree and I went to the station, but could find nothing. At last a porter said a stout man had arrived by train who appeared to be troubled in his mind; that he inquired for a lodging, and had gone to bed. We desired the porter to produce him. $\mathrm{He}$ did so; and Mr. Bowen appeared looking as if 
he was going to be hanged! He explained that everything was ready and packed up, that he went on to the station, leaving his son to follow with a spring-cart, and he had missed the train. There was another train due at nine o'clock the same evening, and we felt sure the goods would arrive by it. When the train arrived the guard said, 'Your goods were on the platform, but the basket was so big it wouldn't go through the door of the van, so we had to leave it behind.' We were all in despair? However, a train was due about five o'clock in the morning, by which the goods arrived. We served them out at morning stables, and they looked very well.

"Scott, Croall \& Sons had made arrangements to put up all the horses, and gave up for our use their yard in Leith Walk, very, conveniently situated.

"Mr. Chiene kindly put his house in Edinburgh at the disposal of the Cupar troop at the time of the review, providing as many beds as possible. Captain Crabtree and I both stayed there, and there were refreshments on the table day and night during the stay of the F.M.R.V."

On the evening of their arrival the whole regiment-in number ninety-two-dined together at the Freemasons' Hall, and before dinner the Earl of Rosslyn administered the oath.

Captain Thomson proposed the health of the non-commissioned officers, coupled with the name of Sergeant-Major John Carstairs of the Kirkcaldy 
troop, who had three times volunteered in defence of his country. He was a member of the Fife Yeomanry, disbanded in 1827 , and also in 1837 , and Fife Light Horse, raised in 1860 . When a discussion took place whether the uniform of the F.M.R.V. should be grey-like most of the Volunteers-or red, John Carstairs of Smeaton said, "If ye mak' it grey, ye'll be like a troop o'. millers. I maun ha'e a red cote, or I'll no join!" It was therefore decided the coats should be red.

"We turned out on the day of the review at eleven o'clock, and proceeded to take up our places in the Queen's Park, in accordance with the following order :-

"'Major-General Lord Rokeby, K.C.B., commanding First Division. Fife Mounted Rifle Volunteers to take post on right of line. Major, the Earl of Rosslyn (Lieutenant-General) commanding. Hour of marching-one o'clock. Entrance-Old London Road. Strength-officers, 9; non-commissioned officers, I 2 ; privates, 72-Total, 93.'

"The weather was beautiful, but the dust was very bad, and the men's faces became quite black. We were formed in close column, each troop told off as a squadron in single rank.

"At last Her Majesty appeared with an escort of the $13^{\text {th }}$, cantering very slowly, and all well in hand. She drove all down the line. Lord Rosslyn was the first volunteer in Scotland who marched past Her Majesty, followed by Lieutenant Cathcart, 
who was his aide-de-camp. I was next, being in command of the leading squadron."

"Edingurgh, 7th August, 1860.

"Major the Earl of Rosslyn has great pleasure in intimating to the Fife Mounted Rifle Volunteers that he has been authorised by Lieutenant-General Sir George Wetherall to inform them that Her Majesty the Queen has been graciously pleased to express her approbation of all that she has seen at the review this day, and has directed the Adjutant-General to issue a general order to that effect.

"Lord Rosslyn cannot allow the F.M.R. Volunteers to quit Edinburgh without thanking them for their conduct and appearance during their stay, and he trusts that by a continuance of ready attention to the details of military drill they will deserve the high reputation of which they have now laid the foundation."

September, I860. - I went to stay with George Loch at Uppat. He had succeeded his father as the Duke's Commissioner. We went by coach to Inverness and posted on, sleeping at Ardguy, and next day got to Uppat.

On the I $^{\text {th }}$ the Duke of Sutherland lent me a rifle and we went out for a deer drive. George Loch was placed behind a big stone on a little hill and I was about roo yards from him. I stood there till I was tired, and then went quietly up to him, having heard nothing. I said, "This deer- 
shooting is all a d-d fallacy". I had hardly said so when a great stag appeared almost under the big stone, about ten yards off, so near that he fired down on it and missed; it turned back and disappeared. I ran back to my place, not so much hoping to see the deer, but hoping that I should not be found out. I had only been there a minute when I saw the deer walking quietly along, broadside on, about 100 yards away. There was a vista down between the trees, and as he passed it I loosed at him, and saw that I had hit him. I ran on a few yards and got another shot, and saw that I had hit him again. I waited till the beaters came up. One of them put a retriever on the scent, and found him dead. This was the only stag I ever shot, and I have never been out again.

The Duchess-Countess was very kind, showing us all over the castle herself.

On the 17 th we hired a carriage at Inverness and drove all round the west coast-Inchdamp, Lochinver, Scourie, Overskey-a wonderful, wild, rocky country; back to Uppat, and then home again by Caledonian Canal, Oban, Loch Lomond, Stirling and Perth. Got home on 23rd September, and commenced hunting on $25^{\text {th }}$ September; Fred Turpin, Jack Wilson and Jim Hewitt, 2nd horseman.

29th October.-I was staying at Pitfirrane. Met at Saline; rained torrents all day; found in Milton Glen; ran through Cleish Wood to Aldie Strips, and lost him. I started to go home wet through. A woman at a farm-house gave me a VOL. I. I6 
glass of whisky and a bit of ginger-bread. I met Jim with "Delicate" and "Constance". As I passed him his horse, "Staniforth," swung round and hit my knee-cap with the point of his hip bone, and broke it into three pieces. I had my mouth full of ginger-bread, and I did not drop it. It did not hurt very much, and my breeches were very tight with the wet. When I got to Saline I got off, coupled the two hounds together, and sent Jim to the kennels at Torry. When I got to Pitfirrane I got off at the stable, walked to the house and upstairs, got a hot bath, and heard my knee-cap crackle. I sent down to Arthur Halkett and said, "Arthur, I have broke my knee-cap". He said, "Gammon, you could not walk if you had". I said, "Put your finger on here and feel". He did so and felt it move, and said, "Go to bed and I'll send for the doctor". I went to bed, had a cup of tea, and fell fast asleep. Dr. Dewar arrived, and said, "If you want to get home you must go directly, for you won't be able to move to-morrow". It was raining hard and blowing a hurricane. I said, "I am in a good billet, so I will stay still". He tied my leg to a board, the edge of which made my leg very sore.

My wife came to Pitfirrane, and on second November Lord Rosslyn sent his "dormeuse" carriage for me. I did not get out again till the I $5^{\text {th }}$ December. I was very shy of anything touching my knee for a long time and wore a thick pad over it ; eventually it got quite well. 
I 8th March.-Invited Captain Sandilands to bring over the Lothian Hounds: Jim Stacey was huntsman. Found in Carnock Moor; ran well for five miles without a check, and killed at Hillside.

Hunting days, seventy-four ; frost, eighteen days ; blank, one; killed twenty-two brace; to ground, eighteen brace.

Jack Wilson succeeded Stephen Dobson as second whip. He was a capital horseman; always got a good start, but generally left some hounds behind. This season we left out thirty-one hounds. The previous season, with Stephen Dobson, only left out one.

Alex. Mackenzie, Delvine, was quartered in Edinburgh in 78 th Highlanders. I invited him out hunting, and gave him a mount on "Chuzzlewit".

I 8th December.-A heavy fall of snow; drifts six feet deep.

27th.-The house at Charleton caught fire. A chimney had been altered the previous year and a flue got full of soot. At seven in the morning a servant came and called me: "Get up, sir ; the house is on fire". I went and put my hand on the wall and it was too hot to touch. My mother was in the room above, and they called and told her. She said, "Take the carpet up and call Mr. Thomson". I dressed myself, put a hatchet in my pocket and got on to the top of the house; found the chimney where smoke and sparks were coming out. The roof of the house was covered with snow. Got Jack Lee with a spade and shovelled snow down the chimney, which $16 *$ 
stopped the draught and became water. Meantime the men from the farm had arrived; they tore down the lath and plaster and put it out, but the house was full of smoke. A feeble voice was heard from the top of the stairs : "Is there any salt in the house? I am told salt is a very good thing to put out a fire!" and the head of Miss Emily Johnstone, with a most becoming night-cap, appeared over the top of the stairs. I received about $\mathscr{L}_{\mathrm{I} 2}$ compensation from the insurance company.

David Williamson hunted with us a good deal that season and stayed with us at Charleton and Pitfirrane. He was a first-rate horseman and a gallant chap across country. He describes his ride home in the following letter:-

\section{"Lawers House, Crieff,}

" I7th April, r86r.

"My Dear Thomson,-

"As I have been thinking of you and your hounds all day, I must indulge myself in giving you an account of a part of your country that I do not think you have ever seen; and at the risk of being considered an egotistical ruffian, I will describe my ride home last Saturday.

"After leaving the hunting-field for season I86I, I hung my head and felt like a schoolboy going back to school. I soon gained the turnpike road that led to the Rumbling Bridge and gates of Muckhart. The road was so hot and disagreeable, that on meeting a truthful-looking face I asked him to point out the position (on the other side of the Ochill 
Hills) of Auchterarder. I immediately left the road and made for the hill-top pointed out, when I found myself in a lovely wild grass hunting country. I saw a good-looking fox cover here and there, and a shepherd said there were plenty of foxes-of this, however, I have some doubts from what he said afterwards. On I went over that lovely turf for four miles without a check. Then I came to a wire fence; I drew the staples of the two top wires, stood on top of them, and when these were pressed down hoped that 'Crump' would jump the others, but nothing would induce him to do so. I could get nothing to break or cut the wires, so I tied the two top wires with my pocket-handkerchief and rode my horse over. On we went again for another mile and a half, when the same process of getting over the wires had to be repeated. These being higher and a soft take off, we struck all round, and felt much like falling.

"Soon after this I crossed a high road which I understood afterwards went between Dunning and Rumbling Bridge. On I went again over those lovely grass hills and valleys, still sticking to my point, when I came to a hill farm-house. Here I got information that I was 'all right'. The farmer was most civil, and knew all about my whereabouts. I then passed through a romantic green narrow glen; again crossed a wire fence, and took my last jump in my pink coat over a low hill gate. Auchterarder soon came in view, and I looked back to twelve miles' ride over the most delightful grass 
with no little pleasure, and forward to the long road journey before me with an equal amount of horror.

"At Auchterarder I had a cup of tea and 'Crump' a lot of gruel. I landed him at Lawers (by-the-bye, fording the river) at 7.30 P.M., cool and fresh and beating my better half by a good half-hour. My good horse fed well, and was as fresh as a twoyear-old on Sunday morning.

"I fear you would have no sport to-day; but as it looks like rain to-night, it may be a better day for the sports to-morrow. I hope you will have the best of luck. And now allow me to thank you very much for the many delightful days' sport I enjoyed with your hounds-my enjoyment was ever doubly enhanced by seeing you in the field. Last night, when dining with a neighbour, we had a long talk about getting up a pack of hounds in this country, Auchterarder as headquarters. I think the thing might be accomplished in time, and if I knew how, I would make an effort for such a good purpose. What is the first thing to be done in making a hunting country, securing subscriptions, etc. ?

"We will always feel the liveliest feelings of gratitude for the kindness we received in Fifeshire this winter, and praying you may long be spared as the leader of religious feeling, of manly sports and honest English thoughts,

"Believe me,

"Yours very truly, "David R. Williamson." 
Season ended Ist May, I862. Hunting days, eighty-five; blank, two; stopped by frost, thirteen ; killed twenty-nine and a half brace; seventeen brace to ground. The best season I have seen in Fife. Jack Wilson went to Lord Yarborough, as second whip; succeeded by Jack Shepherd.

Whitsunday.-I bought East Newburn farm; cost $£ 4,694$; valued at $£ 176$ per annum. Present rent, $£$ I 25 (I892).

The summer of $\mathrm{I} 86 \mathrm{I}$ was principally devoted to volunteering.

At the Queen's Birthday Review in Edinburgh, on I 2 th July, the F.M.R. went over in the morning, I 6 being present ; marched straight to the Queen's Park and formed up between the Scots Greys and the artillery. The moment they were in their places the artillery fired a royal salute. Not one of the horses had ever heard a gun before. They were jammed so close together, and were so frightened, that they did little harm, and the smoke hid any imperfections. They marched past very steadily and made a capital charge.

The first official inspection took place at the New Inn by Major Douglas Jones, inspector for the N.E. District. The kennels of the Fife Hounds were at the New Inn at that time. When drawn up in line, I ordered Turpin to square the horses' tails with a pair of scissors, which had a good effect on their uniformity of appearance. After this all who joined had their horses' tails of the right length. One young gentleman came to drill on his father's 
favourite steed-with a flowing tail-and was horrified to take it home with a respectable "bob"! There were 125 present on parade.

The season of $186 \mathrm{I}$ commenced on 23 rd September. Torrents of rain and a gale of wind, so did not go out. Lots of corn uncut.

2nd November.-Blair Adam. Capital scent ; ran a cracker by Neviston back into Blair Adam. Turpin got a fall, sprained his ankle, and his horse got away. Seven and a half couple went away over the hill at Outh, only Dr. Dewar and myself followed them. I got up to them at Bandrum and stopped them at twenty minutes to four. The doctor went home, and I started nine miles across the moor to Blair Adam. I blew my horn, and Mrs. Adam came out and told me that Turpin had got the rest of the hounds and gone home. I got home at a quarter to nine.

2nd November.-Lady Charlotte Chetwynd was killed by a fall from her horse. She went out for a ride on a new horse with her daughter Georgina. The horse was larger and had higher action than she was used to. It started off in a trot and then in a canter; she appeared to lose her nerve, dropped the reins, and gave a scream in which her daughter joined. The horse broke into a gallop, and at the first turn dashed into the hedge, where he stuck. Lady Chetwynd fell back into the ditch and injured her spine. She was removed to the Hall at Grendon, and died the following morning about six o'clock. She was sister to Lord Down- 
shire. When I first went to Atherstone I knew her and Sir George very intimately, and lived for weeks in their house at Mancetter. They went to live at Grendon after Sir George's father died.

December.-Prince Albert died. 


\section{CHAPTER XVI.}

DERBY DAY.

I862.-In May, Mrs. John Johnstone invited us to stay with her in Eaton Place.

I went to the Derby on Lord Willoughby's coach with Macclesfield, George Fox, Poltimore, Jim Holden, etc. While standing near the coach a gentleman lost his watch. Some of the servants saw the thief, who, seeing that he was observed, threw the watch under the coach and ran away. Just then a rush of pick-pockets came, and we tried to block the way and prevent them passing. I felt something press hard against me, and made a grab with my left hand and caught the chain of my watch, the thief having the watch in his hands. The chain did not break, and he let go of the watch and ran away. Lord Rosslyn was standing by. I said, "Look out, Francis, here is another". I rammed my watch into his hand and ran after my thief. Luckily there was a narrow place between the carriages which delayed him a little. I caught hold of the collar of his coat and laid him on his back. I then put him between the wheels of the coach with his back to the door and stood in front of him while some one went for a policeman. Jim 
Holden, who was on the top of the coach, rammed his hat over his eyes and pulled his hair. A policeman came and I gave him in charge, but he said, "You must come too, sir, to the police-office," and we walked off. When we got to the place where the gipsies throw at the sticks, he said, "I ain't going any further". He was rather a bigger and stronger man than the policeman. I took hold of his wrist in my right hand, made a poker of his arm, took his collar in my left hand and shoved him forward: "Now then, march on". The policeman walked by his side. The carriages were three and four deep up the side of the course, and we had to get into and through them, but I never let go. The course was just cleared for the race, and we marched up in front of the grand stand among the jeers and laughter of many fellows who knew me, and landed him in the police-office. The inspector took down the charge, and said, "You must leave your watch". I said, "It has never been in the hands of the police, I rescued it myself," so he allowed me to keep it. When I got home, I said to myself, "I have got my watch, I spoiled that chap's Derby by getting him locked up, so I won't do any more". But two days after I found a policeman waiting at my lodging with a "subpœna" to attend at Epsom next morning. On arriving there three or four gentlemen were sitting in judgment. One of them said, "It will be some time before your case comes on, you may come and sit in here," so I heard several cases tried. Most of them for gambling, thimble-rig, etc. Several of 
the policemen were in fancy dresses: one was a railo way porter, another a cricketer in flannels, another a waterman with a straw hat and blue jacket, another a Scotsman in a checked suit, and one with a black evening coat and black satin waistcoat. If a policeman did not succeed in getting his victim convicted, he was well chaffed by his companions. When my case came on it was quite clear and no defence, and he got six months' imprisonment.

A hound show in connection with Cleveland Agricultural Show took place at Guisborough on I $5^{\text {th }}$ August. Turpin and I went to it and took "Syren". Tom Parrington was secretary of the show ; Captain Percy Williams, Mr. Mark Milbank and Mr. Gregson, judges. The Cleveland entered a couple; The Quorn their "Blissful"; The Hurworth, "Timely"; Lord Middleton, "Languish"; 'Fife, "Syren"-a bitch of immense power, measuring seven and a half inches round the arm and twenty-eight over her ribs. She fairly overtopped the handsome "Languish" and got first prize as brood bitch, four season hunter, and had reared a litter of puppies. Her sire was Badminton "Primate"; dam, Fife "Scandal".

On the $5^{\text {th }}$ December hounds met at Mount Melville. I was riding a grey horse called "Snowdrop". When I got to the meet "Syren" galloped up to me and touched my horse's hock with her nose. He kicked and killed her-an awful loss.

I wrote to the Earl of Mar:- 


\section{"Charleton, Colinsburgh, "I4th November, 1862.}

"My LORD,-

"I trust that you will pardon the liberty I. take in writing to you, but I venture to do so in my public capacity as Master of the Fife Hounds. Some time ago I received a letter from Mr. Moir, of Alloa, stating that he had your lordship's instructions to desire that the Fife Hounds should in future abstain from going on your lordship's property.

"If your lordship will have the goodness not to insist on this prohibition, I can assure you that I will take every care that no damage shall be done either to the crops or fences, and I have always been careful in attending to the wishes of the tenant of your shootings.

"I am proud to say that the Fife Hounds have the goodwill of every proprietor in the country over which they hunt, and I hope very much that your lordship will also grant us this privilege.

"Again apologising for the liberty I have taken, "I have the honour to be,

"Your Obedt.

"J. Anstruther Thomson."

"AlLOA, I th evening of November, I862.

"The Earl of Mar presents his compliments; but he does not wish any hunting on his estate of Alloa; nor of Forest: because hunting injures fences and young forest trees, and also horses too. And he thinks any of these reasons sufficient. Moreover, he believes there are no foxes on his estate, although people ride about, pretending they have found a fox." 
On 16th December, 1862, the Fifeshire Journal writes: "The Cupar troop dined at the Royal Hotel, Cupar, and presented Captain Thomson with a timepiece; his wife with a brooch, and his son with a hunting-whip. The timepiece had the following inscription: 'Presented to John Anstruther Thomson, Esq. of Charleton, by the non-commissioned officers and privates of the Cupar troop in testimony of their high appreciation of his services as their Captain and of his unwearied zeal in organizing and maintaining the efficiency of the troop'." The chair was taken by Sergeant-Major Bell.

On 4th February, I 863, Lord Wemyss was presented with his picture, painted by Gourlay Steele, at a dinner at Coldstream, and Mr. Robertson invited me to go to Ladykirk, where I met Lord Dalhousie, Mr. Surtees ("Soapy Sponge"), etc. Lord Dalhousie commenced his speech, "No hound ever harked to holloa more readily than I did when invited to do honour to my old friend," etc.

Next day we hunted at Wark Common. Old Cotton was then stud groom to Mr. Robertson. $\mathrm{He}$ had been with me when quartered at Limerick.

This year Lord Stamford gave up the management of the Quorn Hounds. The sale took place on 9th May. I went to Bill Clowes at Woodhouse Eaves on the 7 th and met Lord Henry Bentinck, Mr. Cradock, M.F.H., etc. Will Clowes was at that time successor to Lord Stamford as Master of Quorn Hounds. On the I I th we went over to the Belvoir kennel, Clowes, his brother and I, Jack 
Goddard and Fred Turpin; Cooper was then huntsman.

I was walking from the station with Lord Henry discussing the merits of various huntsmen. I said, "Six days a week is too much for any man". He said, "When the Church is abolished, there will be no obstacle to hunting seven".

Jack Jones, formerly whipper-in in Fife in 1837 , and latterly huntsman to Lord Henry Bentinck, and afterwards with the Lothian Hounds, on being asked what he did when in Lord Henry's service, said, "Hunted every day in the week and played catch-ball on Sundays". On being asked what he meant by catch-ball, he said, "Me and Lord Henry used to chuck a ball in the grass yard for the young ones to run after, to see what sort of action they had. ' Lord a' mercy, how I cussed that ball!"

This season George Moore and I had a team of Charlie Ward's for Ascot Races. Lady Harriet St. Clair went with us, Hugo Meynell and Harry Boucheret. Coming home on the top of the hill in the Long Walk, the carriage in front stopped suddenly and threw my leaders back on the bars. The near leader fired a salute, then jumped forward, and drew the rein through my hand, and the coach ran on to the grass. The road is very high above the park, and we were on the level of the branches of an oak tree. I got a pull at them, and set their heads straight, and went down the hill at a gallop on the grass. When we got on the road again, Lady 
Harriet, ${ }^{1}$ who was on the box with me, said, "It is a good thing that you are pretty strong". It was a very narrow shave, about the worst I ever underwent.

On the Ist July, I863, the Hound Show took place at Redcar. The previous year, at Guisborough, Turpin and I had noticed how dirty in their coats all the hounds appeared which had travelled far by train, and that they did not show to such advantage as those which were nearer home; also that many hounds shown were fed so full that they had no back ribs visible at all. We selected a lot, and set to work to remedy the difficulties. We got a large dog-box, large enough to hold three couple, measured it to fit the door of the guard's van, covered one side with wire netting, and set it on small wheels, so that we could wheel it along. Got it, with its contents, safely into the train at Falkland Road and started for Edinburgh.

This train ran in connection with the London express, and at that time the Fife train went up a tunnel from Scotland Street to Waverley Station, and there was a door of communication between the two stations. On our arrival the express was waiting; our dog-box was trundled out of the van along the platform to the door, when to our horror we found the door was too narrow. We were in despair, but Mr. Brotherston, the energetic stationmaster, was equal to the occasion. Summoning

${ }^{1}$ Lady Harriet, afterwards Countess Munster, was quite lame at the time and walked on crutches. 
all his porters, he gave the word, "Now, lads, shoulder high". Up went box and hounds, and were carried down the line and round into the other station, and placed safely in the van. Arriving at Redcar, they were wheeled to the loose-box where they were to live, and then walked out on the sands on the seashore. Thus we succeeded in avoiding the dust of the railway. Next morning we were out at six o'clock, let them have a long run on the sands, and had them as fresh and light as if they were to go out hunting.

The show is thus described in the Field: "Forth came the Durham lot of three couple, useful but small, and not quite coming up to the standard of merit. Next on the catalogue were the Fife; but on the principle, I suppose, that the first shall be last, and the last first, they were passed over, and did not show till all their competitors had been out. When they did leave their benches, the expression of delight on the countenance of the Lord Chief-Justice (Captain Percy Williams) made some of the ladies even leave their chairs to take a nearer view, while all the male sex were on the qui vive, whether they knew a hound from a pointer or not. A more blood-looking lot, or one with more quality, we certainly never saw ; but even for bitches they were too light of bone for the general taste, and far too shallow in their back ribs. They are evidently as quick as lightning, and look like accounting for almost every fox, while their shoulders are perfect; but for breeding purposes they want that essential VOL. I. 
point, bone. Much, therefore, as we were taken with them as being exactly the right size and sort for our taste, we reluctantly rejected them from our list of probable winners. 'Bonny Lass' is perhaps an exception to our remarks, 'Tempest' and 'Tragedy' being not quite so much so, but 'Charmer' and 'Dairymaid' are cut up in the flank like a greyhound, and if looks are any test, would find one severe day per fortnight quite enough. To our surprise, however, after the Yarborough, Cheshire and Wemyss lot had been out in the order named for final adjudication, the Fife were on the flags again. At length the fiat was pronounced-Fife, first ; Lord Wemyss, second."

As to the assertion that the hounds were light of bone, I insert the measurements :-

\begin{tabular}{|c|c|c|c|c|c|c|c|c|}
\hline Tragedy . & . & • & . & • & $\begin{array}{l}\text { Girth. } \\
29\end{array}$ & $\begin{array}{c}\text { Height. } \\
22 \frac{1}{2}\end{array}$ & $\begin{array}{c}\text { Arm. } \\
7 \frac{1}{4}\end{array}$ & $\begin{array}{c}\text { Under Knee. } \\
4 \frac{1}{2}\end{array}$ \\
\hline Dairymaid & • & $e^{\circ}$ & & $\cdot$ & $28 \frac{3}{4}$ & 224 & $6 \frac{3}{4}$ & $4 \frac{1}{2}$ \\
\hline Symmetry & - & • & • & . & 284 & 22 & 7 & 5 \\
\hline Charmer. & . & • & • & - & 28 & 22 & 7 & 5 \\
\hline Bonny Lass & . & • & ${ }^{\circ}$ & - & $29 \frac{1}{2}$ & $22 \frac{1}{4}$ & $7 \frac{1}{2}$ & 5 \\
\hline Tempest & • & . & . & . & $28 \frac{1}{2}$ & $22 \frac{1}{2}$ & $7 \frac{1}{4}$ & $4 \frac{3}{4}$ \\
\hline
\end{tabular}

As to the alleged deficiency of back ribs, the critic little knew the trouble we had taken that they should not run into the opposite extreme! Another reporter, alluding to the Cheshire hounds, said "Peter Collison had succeeded in getting more flesh on to his hounds than on to himself," and that they were much too high in condition.

The Druid's account is worth quoting : "Turpin, who had been making himself generally useful as first whip, brought out the Fife bitches. They came 
dashing out looking as fresh as smelts, and had had a pretty long promenade over the sands in the morning. Last year there was such a dreadful rough night on the Firth of Forth that they could not be got across to attend the show at Guisborough, so were all left behind except 'Syren'. That beauty of Guisborough had been kicked and killed since then, and her daughter 'Symmetry' was one of the three couple. 'Dairymaid' let them down a bit. If she was the omega, 'Bonny Lass' was quite the alpha of the lot, great quality and bone to the foot, a point in which 'Charmer' was deficient. The rest not very remarkable, but smart and clever, and looking quite a terror to a fox. The Cheshire were out again, and Sir Watkin was sweet on the yellow pies. Then the Yarborough and Lord Wemyss, and the final discussion began in earnest. Captain Williams whipped out his tape line once more. Major Fletcher, who had rather lain off, drew forward. Mr. Milbanke took one of his long quiet surveys, pencil in hand, and Sir Watkin drew his hand across his face as if in judicial difficulties. The Cheshire could not win with one couple, and had too much flesh. The Yarborough not well put together, and seemed uneven. So it was reduced to a Scottish contest,Fife $v$. Coldstream. The issue was narrowed to two and a half couple, by settling that 'Dairymaid' should be set off against 'Rubicon,' and then the Fife had it unanimously. Then the photographing began. Mr. Thomson sat on the reserve seat, a sort of committee of taste. Jack Parker had finished 
his sandwich, and had great difficulty as to the disposal of his hands for posterity. He got them out of sight at last, while Ben placed his right on his shoulder. Will Smith looked the picture of calm resignation. Turpin's air, on the contrary, was decidedly jubilant ; he folded his arms like a 'Canning,' and put his right foot forward. On the extreme right were Carr and Collison. Will Channing's neat lissom figure needed no pose but the natural one. The photographer objected to his hands being behind his back. Mr. Thomson was down upon him in an instant: 'No, no ; that's the way he always standsas you were, Will'. Mr. Parrington was placed on a chair next the table, which was radiant with silver prizes, and two huntsmen (who might as well have appeared in scarlet) were on each side of him. The operator adjured them 'to look pleasant,' and hit them off the first time."

On I 2 th September the sale took place at Sledmere, Sir Tatton Sykes'. There were herds of thoroughbred horses in the park, five years old, which had never been backed. After the sale I went home with Francis Johnstone to a cottage near Hackness, where his father lived. We had a hunt with Lord Middleton's hounds-Ben Morgan, huntsman; and Johnstone mounted me on "Windfall," which he had bought at my sale in I 855 .

On the 18 th I went to Nuneaton by train and got a trap to go to Hartshill. Groing round a corner there was a crashing sound, and I found myself sitting on my portmanteau in the middle of the road-the 
spokes of the wheel had all collapsed. I also went to Appleby and Wynstay, and returned home. Began hunting on 25th September in Fife at Belliston.

Will Clowes was going to be married to Lord Waterpark's sister on the 2nd December at Oakover, Mr. Oakover having married her sister. He asked me to be one of his trustees and to attend his wedding, and I was to have four days out hunting. I went up to Crewe and slept at the hotel there, and next day met Meynell's hounds at Kedliston. "Jacko" Paget (now Sir Ernest) was best man and gave Clowes a silver hunting-horn. I gave Mrs. Clowes a Scotch plaid and a pebble brooch.

The next day I had a mount on "Sweet William" with The Quorn, I think at Kegworth-Jack Goddard, huntsman; Tom Firr, second whip. I was galloping through a farm-yard; a threshing mill was going, and the ground covered with chaff and dust, and the pond also. It all looked alike, and I galloped bang into the pond and got wet through. I afterwards got another cropper and lost my knife-a real good one-out of my breast pocket.

I then went on to Rugby, and John Darby gave me a mount with the North Warwickshire, and I got another cropper, and went on to Oakeley's at Cliff. Next day, Atherstone Hounds at Sibson Wolds. Oakeley mounted me on "Dice-box". At the second fence I jumped into a watering-place, the horse rolled over my leg and it hurt a good deal, but I put my foot into the stirrup and got on again. On going through a gap a branch caught my toe, 
and that hurt more. I jumped one more fence and then found that it would not do. I was about three miles from Cliff, and Charlie Newdegate would insist on riding home with me, and preached about the Pope and the Jesuits the whole time. When I got to Cliff I cut my boot off.

I wrote to my wife :-

"Cliff House, Atherstone,

"Tuesday, 8th December, 1863.

"After I wrote to you last night Mrs. Oakeley insisted on sending for the doctor. He said going home to-morrow was out of the question, that I must not go for at least a week, and that the small bone at the ankle was broken. So I suppose it is, and there is nothing to be done but be patient. It does not hurt. I don't care much for myself, but I am sorry to give you anxiety about it, and you won't be able to realise it, as you say.

"To say that they are kind is nothing. They think and do all day everything for me, and Mrs. Oakeley is writing to ask you to come and bring all the children. That is out of the question, I have told her, but she says 'Bring Jack'. I don't know what to say to you to do. Of course, I should like you to be with me, but you would not like the children to be without you, and I think a journey here and back would be a risk for Jack. You and Doodlie must take counsel and settle for yourselves, and I shall be resigned to my fate."

1 was at Cliff from 7 th December till inth January, and was very happy all the time, and 
treated with the greatest kindness. I got home about the 12 th, and got out hunting at Clatto Barns on "Highlander" on the 25 th.

\section{The Cliff AlphaBet.}

A stands for Aunt Mary, so clever and able.

$\mathrm{B}$ for the Bumpers we drink at her table.

C for Cliff House, in which she doth dwell.

D Diddy.Bo, the dog, known so well.

$\mathrm{E}$ the Encounter 'twixt Diddy and Zoe.

$F$ the Fine Carving so effective and showy.

$\mathrm{G}$ is "Garibaldi," that horse of renown.

$\mathrm{H}$ are the Horses well cared for by Brown.

I the invite to young George Moore's Ball.

$\mathrm{J}$ poor Jack Thomson laid up by a fall.

$\mathrm{K}$ is for Kelly, the "swell of the hunt".

$\mathrm{L}$ is the Lathe with which his tools he doth blunt.

$\mathrm{M}$ the Mistakes Mary makes in her sewing.

$\mathrm{N}$ all the Needles she breaks in so doing.

O stands for Miss Oakeley, who keeps very well.

$\mathrm{P}$ is the Pity, for 'tis rather a sell.

$Q$ is the Quaintness of old gardener Mike,

$\mathrm{R}$ are the Rampions which he cannot strike.

$\mathrm{S}$ are the Stews made by that good old Thorley.

$T$ stands for Trotman, of maids the most worthy.

$\mathrm{U}$ are the Unpaid Bills coming in.

$\mathrm{V}$ is for Vass, worked hard but not thin.

By Quicksilver, I5th December, I863.

"Quicksilver"-Mrs. Colvile.

"Aunt Mary"-Mrs. Oakeley.

"Diddy-Bo"-her dog.

"Zoe "-Lady de Clifford's dog.

"Fine carving"-made by themselves in wood, in the dining-room.

"Garibaldi "- her horse.

"Solomon Brown"-the groom.

"A ball on the 30 th" $-\mathrm{G}$. Moore comes of age.

"Kelly"-Mr. Oakeley, "the swell of the hunt".

"Rampions"-sort of radishes.

"Thorley"-the cook.

"Trotman"-Mrs. O.'s maid.

"Vass"-the butler. 
I863.-Mark Napier went to a fancy ball in Edinburgh dressed as an old Lady, and no one could tell who he was. He wrote this letter to my wife :-

"My Dear Marion,

"My bonnie bird-ye'll surely no be expectin' me to ca' ye mistress, wha kent ye when ye were a bairn? And speaking o' that (my doo), I mind, in my bairnage, mistress meant miss, and miss meant mistress. Monkbarns, my brither, never can get out o't yet. He was speaking to a literary lady, no further gaen than yestreen, about a grand scheme of hers for feeding a' folk, rich and poor, for a penny fee, which took the laird's fancy to that degree, that, my certie, puir Maggie Mucklebacket will no hae a chance wi' him in their next fish bargain. 'Weel,' says my brither, 'ye're ower young to remember Mistress Catherine.' But, faith, when Monkbarns (wha of course meant Miss) got that length, he got no further in that speech, for the lady took sic pains to let him ken that she was nocht married (and ye'll mind neither is Monkbarns) that the laird got quite flustered, and their discourse got into sic a wrangle about miss and mistress that he'll be for ca'in me miss; and if he does, 'od I'll gie him his kail through the reek. But I fear I'm ramblin'. I've sent ye this, wi' my card (for we're a' cards noo-nothing to be done without cards, and pictures on them now-how fashions change to be sure!-they mak' the very sun do things now that for the very life o' him he 
couldna do afore), to speir for your bedfellow, for they tell me he has taen an awfu coup aff his horse. Monkbarns has been sair taen up about it, for he kent his father, and was jilted by his mother; but Monkbarns is no the man to bear malice. Weel, I made him understand that your goodman (wha, to my mind, will ever be the callant I saw him last) had a sair fa' frae his powny. 'Do ye mean the Laird o' Charleton, Grizzy?' 'The same,' says I. 'A powny woman! The Laird o' Charleton rides a porwny, no a hand less than the horse that took Troy; and as he and his saddle are no easy to part, his fall would be like that of Antous (?). It would ring the kirk-bell if he was in sicht of the belfry. But what's happened? Has he broke his neck?' 'Praise aboon, no jist that, Monkbarns. But, faith, he was ower near it. He has broken his ankle bane.' 'His ankle bane, woman! If a breakage never comes nearer his neck than that, it's safe enough till he's hanged. The Laird of Charleton's ankle is about a mile from his neck. But send and speir for the lad, send and speir for him.' So ye see I am just doing the laird's bidding, but wi' a' my ain heart. And there's my card picture; and that's the dress I had on at a fancy ball, where I was mair taen up wi', and taen out and oftener on the floor, than some misses they ca'd beauties. My certie, had they seen the young mistresses that were beauties in my time! And I was amang the first that showed and shined; and 'tweel, the shine's no oot 'o' me yet, as ye may see by this same. 
"And wha should I see there but my auld Joe, your uncle the Laird of Alva; ay, wha but he, wi' his bonnie young bird of a new, wife. 'Eh! Alva,' says I, 'I'm glad to see ye-dinna keep her in a cage! She's dancin', I see, wi' a brave young callant just now ; but she'll no flee far from sic a cage as ye have put her in.' Alva really looks cagie and croose, and disna care a wheat strae for the auld sang, 'What can a young lassie do wi' an auld man'.

"And so, my doo, for the present,

"Yours to command,

"Grizzy Oldbuck.

"Monkbarns House, 24th March, I794." 


\section{CHAPTER XVII.}

HENRY LOCH IN CHINA.

Henry Loch and his wife came to stay with us at Charleton in 1862.

"Charleton, 14th October, 1862.

" My Dear Maria,-

"I have attempted at your request to write a short account of the proceedings that led to the capture of myself and others in China, and of the treatment Parkes and I received while prisoners.

"In a short account of this nature it is impossible to enter into many of the details or state all that occurred, but I hope I have stated enough to give you a general impression of what took place.

"What I have written I have written very hastily, and I may therefore have repeated myself occasionally and made many mistakes in the way of leaving many words out, etc., but as you expressed a wish to have it before I left Charleton, I have no time to go over it again.

"Believe me

"As your affectionate cousin,

$$
\text { "Henry B. Loch." }
$$


"In consequence of negotiations that had been opened between the Chinese Government and Lord Elgin to bring about a settlement of the difficulties that existed between the two countries, Messrs. Parkes and Wades were dispatched on the I4th September, I860, to Mootoo, a place about twelve miles in advance of where the army was halted, for the purpose of meeting the commissioners appointed by the Emperor of China and discussing the preliminaries of peace. On the $15^{\text {th }}$ they returned thoroughly successful, the Chinese having agreed to all the demands made by Lord Elgin, and a letter was written by the Chinese commissioners to that effect. Messrs. Parkes and Wade had, however, been obliged to go to Yung-chow to meet them, as Mootoo being but a very small village there was no accommodation for their retinue. The details of the treaty had yet to be arranged, and various arrangements connected with Lord Elgin's going to Peking had to be discussed and settled, and for this purpose it was agreed that Mr. Parkes and myself should go to Yung-chow on the 17 th. It had also been agreed that the allied armies should advance to within seven miles of Yung-chow, from which point only an escort was to accompany Lord Elgin. The exact halting-place for our army was also to be decided upon in our conference on the I 7 th, and it was arranged that the army should march from its present halting-place, Hooshi-a-who, on the morning of the 18 th and be met by Colonel Walker of the Quartermaster-General's department, 
to point out the ground that had been agreed upon for their encampment. Colonel Walker was to accompany us for this purpose, and Mr. Thompson of the commissariat was also to go, to obtain supplies for the army.

"On the morning of the I 7 th September, an hour before daylight, we started for Yung-chow. The party consisted of Colonel Walker, Mr. Thompson, Mr. Anderson (who commanded the escort), Mr. B. (?), Mr. de Norman, six men of the K. D. Guards and 20 sowars. It was a fine cool morning and we went off in great spirits; the distance to Yung-chow was about twenty-five miles. We did not see a soldier until we arrived at Mootoo. The country we rode through was highly cultivated, with villages every three-quarters of a mile, each'surrounded with its clump of trees. Clumps of trees were also scattered about the country, which gave a very picturesque appearance to the scenery. At Mootoo we saw a picquet of some thirty cavalry, who slowly retired as we advanced. The town was nearly deserted (it has since been burned). After this we passed various other picquets, but they took no notice of us, except by quietly retiring as we advanced. Before arriving at a town called Changkia-wang, which is about six miles from Yung-chow, we passed the ground on which it was settled our army should halt the following morning. From this point it was understood only I,000 men were to accompany Lord Elgin as an escort. As we passed over this ground there was no appearance 
of any obstacles being raised to our taking quiet possession of it. As we were passing through Chang-kia-wang we were met by a military mandarin who said he could not suffer us to advance without knowing our business. We informed him we were going to Yung-chow to meet the commissioners, on which he immediately suffered us to pass. At about 10.30 we arrived at Yung-chow. We passed through the city to the quarters prepared for us, which were in a large temple just outside the gate in the south suburb. We breakfasted, and refreshed ourselves by a good wash, and had just finished when the commissioners arrived. Parkes and I then went into the room prepared for the transaction of business, and after the usual civilities had been gone through, we proceeded to discuss the various arrangements necessary for carrying into effect the treaty. But Parkes soon found the commissioners in a very different humour than they had been in when he had seen them two days before. They raised all kinds of difficulties; would discuss questions that might have been settled afterwards, and which had nothing to do with deciding whether there was to be peace or war, and the whole tone of the commissioners was very unsatisfactory. However, towards the evening they became more reasonable, and suddenly changing their manner entered seriously upon the questions that had to be decided at once. They agreed to the place chosen for our army to halt; they wrote a proclamation of peace that was to be at once 
printed and circulated, and gave orders for the issue of supplies to the allied armies; and we went to dinner at past seven o'clock more satisfied with the appearance of things. It was arranged that in the morning Parkes, Walker, Thompson and myself, with a small escort, should go to the ground where our army was to halt and point it out to Sir Hope Grant. The remainder of the escort and party were to remain in Yung-chow until Parkes and I returned to them, as we then intended getting a house for Lord Elgin, as the embassy were to take up their residence in Yung-chow for a few days before going to Peking. A Chinese officer of high rank was ordered to attend us, and at a little after sunrise of the morning of the 18 th we started to Changkia-wang. We took all the K. D. Guards and three Sikhs. We did not go through the city, but passed through the open country, and after a gallop of six miles arrived at Chang-kia-wang. All the way along we had observed groups of soldiers hurrying in the same direction as ourselves, and when we arrived at this town we found it full of troops. We passed through without being interfered with, but when we got into the open plain beyond we found it covered with cavalry and infantry. Large bodies of the former were dismounted in dry water-courses extending for two miles to the right; the road was for miles lined with infantry, and to the left we saw troops as far as we could see. We moved quietly along the road. I rode to the right to examine the position of their cavalry, 
and after going a mile was joined by Parkes, and rode into a village that commanded the road along which our army had to advance. In passing through it we found it filled with soldiers, and a heavy masked battery of twelve guns pointing down the road. We here got on to the road again and joined Colonel Walker and the others. Our position, as also that of our army, was a very serious one. We had now arrived at the front of the Chinese army; their infantry were lying down behind an embankment that ran along the bank of a stream which ran in a semicircle and protected and concealed the whole Chinese army. In this semicircle there were upwards of a hundred guns in masked batteries. We tried to communicate with some officer in command, but failed to do so. After a short consultation it was decided that Parkes with one of the K. D. Guards should return to Yung-chow to try and get out those who had remained behind, and also if possible to see the Prince of Tsai, who was the senior commissioner, and learn from him the cause of the threatening attitude the Chinese army had assumed, and attempt to delay hostilities until those in Yung-chow could escape. Colonel Walker was to remain on the outskirts of the Chinese army until Parkes' return, unless he found it necessary for the safety of his men to gallop for it-which he could do at any moment with the open country in the direction of our army - and I was to try and get out to the army and inform Sir Hope Grant of the state of affairs, and delay the action that 
threatened, if possible for two hours, to give time for Parkes and the others to get out. I took with me the three Sikhs. After leaving the main body of the Chinese army, I rode along the road by which our army must advance; but I had not gone half a mile when I found a strong force of Chinese cavalry extending for at least two miles, moving in a formation not unlike sections of threes across their front from left to right. They said nothing to me, but gave me no space to pass, so I was obliged to gallop, followed by the Sikhs, at the first opening, and to my surprise they did not resent my doing so. Within a quarter of a mile of this I met our advance guard. Brabazon was with it. I asked him to halt until I had communicated with the General, whom I met half a mile in rear at the head of the column. They had just come in sight of the Chinese cavalry, who were passing round the left flank as if to get in rear. I informed him of the changed aspect of affairs. The French, who were on the right, now sent to say their right flank was threatened, and wished to engage as their troops came up; but Sir Hope Grant decided on massing his baggage in a village to the rear, and getting his whole force up if possible before he acted on the offensive. I asked him how long he thought it possible he could put off the action, and he said not above an hour. I mentioned the importance it was for those at Yung-chow to delay it as much as possible, and begged him, as the time he could give was so much less than Parkes hoped might be VOL. I. 
allowed, that he would give me a fresh sawor to go back to Yung-chow and hurry them out. This Sir H. Grant at once did, promising not to fight until forced into it by the Chinese, who at any moment might force on the battle.

"Two Sikhs of Probyns' Horse were placed under my orders, and fixing my handkerchief on the spear-head of one to represent a flag of truce, we galloped towards the Chinese lines. Poor Brabazon, as I was starting, asked to be allowed to accompany me, and he joined me at a gallop before we reached the first line of the enemy's skirmishers. They allowed us through, but at the main body we were stopped, but by pointing to my flag of truce and pushing past them, they allowed us to continue, and we did not once go out of a gallop until we arrived at the quarters we had had in Yung-chow. There I found, the escort quite unconscious of danger. All the gentlemen were out shopping. Parkes had been there, but finding none of them in had left a note in pencil on the table for them, and had ridden on to try and find the Prince Tsai. As Parkes did not know Hindostanee he had been unable to tell the escort to get ready. I at once gave orders for them to prepare, and in the meantime de Norman, Huntly and Anderson came in. I then went with de Norman to look for Parkes in the city, and soon met him coming from the Prince Tsai, whom he had seen. He said no time was to be lost in making our escape. I then informed him of the state of things with our army. We found 
the escort mounted and ready, and we rode hard to get to our army before the action commenced. As far as Chang-kai-wang we got on well, but the town was so crowded with soldiers we could not go out of a walk. As we cleared the town we broke into a canter, but we had not gone a quarter of a mile when fire suddenly opened from more than a hundred guns, and in a few minutes we saw some shells bursting in the air. We now pushed on at a hard gallop. Anderson and I were riding in front, the road was narrow, and the bank lined with infantry; a large body of cavalry were galloping on our right flank and rear with matchlocks ready to fire. Going at this pace had much the appearance of running away, and half our saddles would have been emptied by the fire they were going to open on us, and which we had no power of returning. Anderson and I, therefore, thought it better to halt-to get the cavalry in front of us, so as to charge through them if necessary, and also to decide what was to be done. As soon as we halted a Chinese officer rode up and with great civility said that he perceived we were bearers of a flag of truce, but that as the battle had begun he could not let us through the middle of their lines, but that the General who was close by would no doubt give us a free pass round the flank of the army, and that he would either send, or perhaps the quickest way would be if any two of us would go with him to the General. We had a short consultation; Brabazon voted that Parkes should decide what was to be 
done. In the meantime I rode up a steep bank to the right, and found the ground so cut up with water-courses and full of cavalry and infantry, that rendered escape almost hopeless in that direction. We decided, therefore, in the first instance to try for a pass; if that failed, to fight for it. Parkes expressed his readiness to go to the General if I went with him, and we galloped off accompanied by the Chinese officer and the old Sikh who had come in with me as bearer of a flag of truce.

"The millet in some parts was not yet off the ground. It grows to an immense height and thickness, quite sufficient to conceal a man on horseback. Round a field of this the Chinese officer led us at a gallop, and we found ourselves in the midst of a body of infantry, who would have shot us down but for the officer rushing in between. We pushed through them towards a small stream, on the opposite bank of which we saw some mounted mandarins. As we got near the cry of 'Sang, Sang' ('The Prince, the Prince') was raised, and up galloped Prince Sangko-lin-sin, the Commander-in-Chief, at that time, of the Chinese armies. As soon as he came near Parkes called to him, and begged he would give us a free pass for the escort to our army, but the only answer he received was a volley of abuse. The infantry had closed in upon us, half a dozen matchlocks were pressing against our bodies with matches ready to blow us out of our saddles. Parkes turned to me and said, "I fear we are prisoners'. We consulted for a few moments if 
resistance was possible, but as the slightest effort would have led to our immediate death, we thought it better to be resigned as we had no help for it, and hope for something occurring that we might take advantage of. We were pulled off our horses, taken across the stream, and shoved down on our knees before Sangko-lin-sin; our heads were rubbed in the dirt; but after a good deal of abuse he had to gallop off, and he ordered us to be taken to the Prince Tsai. We were placed in a cart with the old Sikh, and two Frenchmen who had somehow been captured in another part of the field, and taken off to Yung-chow. Four mules were harnessed to the cart and they took us at a hard trot over the most awful roads. The Prince Tsai not being in the city, we were driven through the town along the Peking road. Our escort inquired as they went for the Prince, for they had been ordered to hand us over to him. The road we were now taken along was crowded with troops. After proceeding about a mile along it, we came to a very handsome stone bridge, crossing the Peking canal, called Pah-li-chow. We were taken across the bridge, but we had not gone far when an order came for us to return, and we were taken into a large camp on the south side of it. We were taken out of the cart and led before the General commanding, whose name was Juli. He was also one of the ministers of state. We were thrown down upon our knees before him, and underwent a long examination, utterly useless, for of course Parkes never gave the information they desired to 
have, and they would not believe any correct information that he did give them. To bring this painful examination to an end, Parkes pretended faintness: We were then removed into a small farm-house, where we were searched and had our watches, papers, etc., taken from us. We were left in this place for half an hour, when we were removed to a temple close by. We were left here alone for twenty minutes, and being tired and having probably a hard day still before us, we lay down for a short sleep. We were roused by the soldiers coming to take us before other examiners, who we found were members of the Prince Tsai suite, men of inferior rank, who had been present at the negotiations of the previous day, but who then would not have presumed to have sat down in our presence without our permission. Now we were on our knees before them, the soldiers cuffing and beating us if we attempted to resist. The examiners were very brutal, especially one man, who insisted that I could speak Chinese, abused Parkes when he said I could not, and had me kicked when I could not reply. In the middle, however, of these proceedings a messenger arrived and gave a message which seemed to create a panic, for they left the room, and Parkes and I were left almost alone. But in a few minutes a number of soldiers rushed in and bound us with our hands behind our backs, and from their cries Parkes was led to believe they intended beheading us. We were led into a courtyard, the guard shaking their spears and brandishing their swords at us. Parkes 
told me if they raised my hands, which when bound behind the back has the effect of throwing the head forward, and ran me forward at the same time, they would behead me at the outer gate-that this was their mode of beheading their criminals. We had time but for a few words and to bid each other good-bye, when my arms were seized in the manner described by Parkes and I was rushed out towards the outer gate, a man running by my side with a drawn sword. While passing through the last courtyard I observed a man running as fast as he could to meet us. We arrived at the gate at the same moment; he threw his arms round the fellow who had the sword, being too blown to speak, and then hurried me forward to a cart, into which I was pitched, and Parkes, the old Sikh, and the two Frenchmen were put in also. These three last we had not seen for some time. The cart immediately drove off at a rapid rate, recrossed the bridge, and along the paved road leading to Peking.

"The agony of that drive I can never forgetthe jolting on the paved road, bound and helpless to save ourselves from the fearful jolts that seemed to threaten each moment to drive life out of our bodies, not for one instant still, thrown backwards and forwards, with the great pain our wrists gave us from being so tightly bound. It seemed impossible that we could hold out long. With our teeth clenched and our feet pressing against each other's bodies, we tried to steady ourselves; but had it not been that the cart had occasionally to go on 
to a road at the side that was not paved I do not think one of us could have lasted through those terrible seven hours of torture. The men of the Prince Tsai suite, whose examination of us had been interrupted, rode in rear, and seemed immensely to enjoy any extra jolt we got. The line of road all the way to Peking was one large camp-for miles on either side of the road were tents with earth breastworks thrown up round them.

"It was dusk before we reached the suburbs of Peking-crowds of people pressing round the cart to get a view of us, and the Chinese soldiers delighted in making the most of their triumph, no doubt hoping it would be thought we were only the first instalment of the whole barbarian army which they had promised to annihilate. As the crowd kept pressing upon the cart, I heard Parkes exclaim, 'What a lovely girl!' I raised my head to the edge of the cart and indeed saw a beautiful face looking at us. To have attracted our attention at such a moment it must have been lovely. Soon after passing under the great gate into Peking, which is imposing from its great height, it became too dark to distinguish objects. Street after street we.passed through, and it seemed we were never going to stop. We were very exhausted from pain and fatigue and want of food and water. At last the cart turned into a large courtyard, and on the paper lanterns hung up Parkes read 'Board of Punishments'. Our worst fears were realised: we were in the hands of a board noted for its cruelty and the tortures it inflicted. Parkes was first taken 
from the cart. I waited anxiously: in about a quarter of an hour I heard the clank of chains, and looking over the cart saw poor Parkes being led away in irons, a man with a lantern going before him. I called out to him. He bid me good-bye in case we were separated, and said, 'The chains are not very heavy'.

"In a few minutes I was led before three mandarins, who were seated in a small room. I was forced to kneel in front of a table at which they sat-a torturer on either side of me holding my hair and beard, which they occasionally pulled when any question was addressed to me. On one side of the room was a low flat wooden bed, with rollers and ropes at each end, and I had no difficulty in recognising a rude kind of rack. On the walls and on the table were different instruments of torture. Getting very tired of the cuffs and kicks I got when unable to answer the questions put to me, which being in Chinese I was unable to understand, I made signs with my head for my hat, which had been knocked off, and which was lying in front of me, and at the same time made an effort to rise, on which I was knocked down on my face, and had it repeated two or three times. An iron collar was then fastened round my neck, with a long heavy chain descending from it. I was then removed through various courtyards into one where I found Parkes seated on a bench, having irons fastened on his ankles. The same was done to me. I fortunately had on jackboots, which protected my ankles somewhat from the 
two rings they fastened round them, to which were attached two chains which were passed through the chain that descended from my neck, allowing my feet six inches from each other. We felt now we were to be separated, and it appeared to me the greatest trial I had yet gone through-probably the last time we should ever meet, or I should see any one with whom I could converse. A hasty good-bye, and we were led away in different directions.

"After passing through one or two courtyards and passages, I was taken into a court rather larger than the others, on one side of which was a barnlike building, through the grated windows of which streamed a flood of light. The jailers who conducted me gave three heavy bangs at the door, calling out at the same time. The door was instantly thrown open, and I found myself in a long room full of Chinese, nearly all of them half naked, and some in the most awful state of wretchedness and disease-upwards of fifty altogether, and about nineteen were in chains like myself, but lighter ones. They all pressed round me; the jailers now again searched me, but only found a small prayer-book which had escaped their attention in the first search. It being necessary to put irons on my wrists, they had to undo the cords that bound them behind my back. This was an immense relief, although one hand was nearly black from the circulation being so long stopped. I had little sensation in it. Fortunately I had a ring on one of the fingers of that hand, and they rubbed until sufficient circulation had been produced to enable 
them to get the ring off. My hands were then fettered together, and my elbows pinioned by a rope ; the chain connecting my hands also passed through the chain from my neck. After giving me a small cup of tea, which tasted better than anything I had ever remembered drinking before in my life, I was taken to the place where I was to sleep. On either side the room, about two and a half feet from the ground, were rude wooden shelves, not unlike guardroom beds, extending from the walls about eight feet towards the centre of the room, leaving a passage between them running the whole length; in the centre there was a slight division with better accommodation for the jailers, with a table, etc. I was placed on the shelf under a chain that descended from a beam, to which the chain that passed from my neck to my heels was made fast, but leaving me sufficiently at liberty as to be able to lie on my back. About half a dozen only were chained up in this manner besides myself, and these were criminals of the most dangerous description, who were in prison for murders and the worst kind of crimes. I did not find much room-my neighbours on either side being pressed so close to me I could not have turned, even if my chains would have permitted of my doing so. Exhausted from want of food, and fatigue both of mind and body, I fell almost immediately asleep. About four o'clock I awoke cold and faint. As I woke and heard the rattle of my chains and felt the strange place I was in, with the almost certainty of a speedy death, the prospect before me seemed dismal 
indeed. The prisoner next me waking from feeling me shivering with cold, threw half of his worn old coverlet over me, and creeping as it was with vermin I could not help welcoming it, and in a few minutes I was asleep again, and did not awake until the stir of the jailers and prisoners about daylight roused me. Shortly before sunrise the door was opened, and my first day of prison life commenced.

"One day was so much like another, that in describing one, it does for all. When the door was opened all the prisoners hurried into the yard, and I was unchained from the beam and allowed to go also. I was immediately the centre of curiosity, the prisoners and jailers crowding round me, examining my boots, coat, hat, and all my clothes. Not liking this familiarity, and knowing an Eastern will often acknowledge authority if it is usurped with sufficient confidence, I shuffled to the only bench that was in the yard, and motioning to two men who were on it to rise, seated myself on it, and waved to them to stand up and away from in front of me. To my surprise and pleasure they did as I directed, but not wishing to test their patience too long, I bowed to them to sit down. From that moment I was always treated with the greatest respect; the best seat was always offered to me, and all the prisoners were ready at any time to do anything that I might require of them. A little after sunrise two mandarins belonging to the prison came in and saw the millet, which is the food for the worst kind of prisoners, measured out. This is the prison fare; the other 
prisoners who are to be better fed are so at the expense of one of the other prisoners who may have means of his own, or friends who supply those means, so that he may obtain his release sooner. Some of the prisoners were really very well fed. Whether they contributed anything towards their own food I could not learn. I was given rice with a little cabbage, which, although small in quantity and not nourishing, was far better than the millet. After the millet was measured out, I was taken before the mandarins and had to kneel, and underwent a great deal of questioning, none of which I could, of course, understand. I was then taken inside and given a bowl of rice, which, as it was nearly the first food I had had for thirty-six hours, was very acceptable. My elbows were unpinioned to allow me to eat, and my first lesson in chopsticks commenced.

"There were about forty-eight prisoners in my prison. Nineteen of these besides myself had chains on, although not heavy like mine; about fifteen by length of imprisonment had had their chains taken off and been promoted to better feeding-all these were the worst sort of criminals. The other prisoners were in on suspicion and waiting for trial, or until such time as they or their friends could pay a sufficient bribe for their being released.

"After my bowl of rice I was allowed into the yard again until 3.30 , when I had more rice. I was again allowed into the yard an hour before we were locked up for the night. The first two or three days a great number of mandarins came to see me, some 
from curiosity, some to attempt to make me speak Chinese. To all of these I was forced on my knees and received abuse and cuffs. These visits, however, soon became less frequent, and I employed my time trying to learn Chinese words and sentences, and by signs tried to learn what was going on outside. With a piece of mortar I got out of the wall I kept the days of the month and week, and wrote my name on different bricks, so that in the event of our army taking Peking and searching the prisons, they would know I had been there and alive on a certain day. Sometimes the jailers gave me a brush and Indian ink such as they write with, and when I got these I kept a diary in the lining of my hat. In the evening both jailers and prisoners used to gather round me and attempt to learn a few words of English, as I did of Chinese. By signs I imagined I had learnt a good deal of the state of affairs outside. The second day, at my request, the prayer-book that had been taken from me was returned. The jailers were sometimes civil, sometimes very much the reverse, and their treatment severe. Pie was the name of the head jailer; he once tightened my chains most unpleasantly. Cao was the name of the third jailer -hideously ugly, but very vain of his beauty. $\mathrm{He}$ had a great desire I should try and draw him, and got a brush and ink and paper for me. I could not resist the temptation, and made him even more frightful than he was, which I learnt to my cost was most impolitic on my part.

"During all this time I could hear nothing of 
Parkes. They told me he was still in the Board of Punishments, but I could learn nothing more. I began to sing 'Pestal' one day, thinking Parkes might be within hearing, but it sounded so melancholy hearing my own voice, and the prisoners all looked so astonished, I could not go on.

"Thus the days passed drearily on, until one morning, by signs and a few words that I had learnt, they told me that my chains were to be taken off, but for what purpose-whether for my final release -I could not learn. About four in the afternoon I was taken into a side room that opened from the yard, and was visited by Hangki, one of the commissioners, and a mandarin whom Parkes had known formerly at Canton. He pretended indignation at seeing me in chains, although he had been one of those concerned in our capture. He ordered them to be taken off. Before taking me away, I went round to the prisoners and bid them good-bye in the Chinese way, with my hands clasped, and as I had seen the few prisoners who had been released while I had been in prison do before leaving. Hangki led me by the hand through various courtyards into a small room, where I was joined in a few minutes by Parkes. Our delight at seeing each other was great. Parkes could not, however, tell what was to be done with us. He only knew we were very far from a final release, and that the only change at present was we were to be better treated. We had hardly been five minutes together when the arrangements for our departure were completed, and we were put into 
separate carts, but of a very different kind to the one in which we had made the journey to Peking. These are made expressly for mandarins to travel in, are covered over and lined with cushions. Two of my jailers, now transformed into servants, accompanied me, and surrounded by a very large escort, we were taken through the streets towards the north side of the city. Thousands of people filled the streets and stood on the tops of the houses to see us as we passed, the police going in front clearing a space for us to pass by cracking long whips at the people's faces. After proceeding nearly three miles we arrived at a temple not far from the north gate, and found an inner courtyard given up entirely to us. One room that opened into it was prepared as our sleeping and sitting-room, the next room was for our servants, lately jailers, and the building that formed the opposite side of the court was for a picked guard of twenty Tartars-the finest men, I think, I ever saw. Surrounding the building a camp of 5,000 soldiers was formed, so we were well secured. It was an immense comfort to be so well lodged after so much suffering. We found tubs and hot water, towels and soap, and were informed we could have dinner as soon as we liked. The delights of the wash and the repugnance at having to put on again the clothes that had not been off our backs for so many days was very great. The dinner was very extensive-sixteen large and about thirty small dishes. We begged that in future they would confine the dinner to four dishes. 
"I now learnt from Parkes the state of affairs as far as he could learn them, and the cause of the improvement in our treatment. It appeared the Chinese Government, after our capture, were very much puzzled to know what to do next. The capture had not put a stop to hostilities - in fact, although they would not admit it, it appeared the Chinese army had not only been beaten the day that we were captured, but in another battle that had taken place a few days later, and that now there was no army between the allied forces and Peking. This we imagined must be the state of affairs from some admissions, although they would not tell us where our army was. They felt, after their act of treachery in capturing us, there would be great difficulty in re-opening negotiations, and we felt pretty certain that Lord Elgin would insist on our being surrendered up before he would consent to negotiate at all. The Chinese would hesitate greatly to do this, for they could not banish from their minds that holding us prisoners, we were to a certain extent hostages for the safety of the city, by the threat held out that we should be put to death if our army advanced against Peking. They were, therefore, in this difficultythreatened by Lord Elgin with destruction if they put us to death, and if they released us, feeling they gave up the only hold they had to induce Lord Elgin to mitigate any of his demands; besides believing we should, out of revenge, urge Lord Elgin to advance still more objectionable demands than he had yet done. And although letters passed between VOL. I. 
Lord Elgin and the Chinese Government, conveyed by subordinates, none of the mandarins would consent to negotiate personally with any one Lord Elgin might appoint to meet them, for fear of being treated in the way we had been; and of course after what had happened to us, none of our officers could come to the Chinese commissioners.

"The Chinese saw no way of escaping from their difficulties except by fighting to the last. In Peking there were upwards of 100,000 soldiers. It was immensely strong, and they thought if they could hold out for six weeks, winter would force us to retreat. If they decided on this course of action, we were to be beheaded to prevent any drawing back, for they knew this would commit all the mandarins to fight to the last. However, at the urgent entreaty of Hangki and a few others, they decided on giving negotiations one chance more, and with this object in view Hangki had visited Parkes in prison, begged him to write letters to Lord Elgin to detain the army, and not to advance on Peking. Nothing would persuade Hangki that Parkes was powerless at any time to control the policy of Lord Elgin or the movements of the troops, and that any little influence he might have had vanished with his becoming a prisoner ; and besides, he said, 'I can only write, dating from this prison, and describing myself as being in chains'. Hangki said if he would write all this might be altered, and had his chains taken off, and proposed to take him to the temple we were afterwards removed to. But Parkes declined to go unless I was to go also; 
that we had been employed on the same service and had been captured together. Hangki made some difficulty as to this, but the following day I was released and taken as I have described with Parkes to the temple.

"We had scarcely finished dinner when Hangki came to claim the fulfilment of Parkes' promise to write a letter. He dictated to Parkes what he wished said, and Parkes wrote it in Chinese, and as Hangki dictated it in the plural, Parkes said when he had finished, 'it required also the approval of Loch, and as he can't write Chinese he must just write across in English he approves'. Hangki readily agreed to this, and suspecting they had a man who could read English, I wrote in Hindostanee, although in English characters, that the letter was written at the dictation of the Chinese Government, and signed my name. We afterwards learned that this was the first intimation that Lord Elgin had received of our being alive. Each day we received visits from Hangki and other mandarins; endless discussions ensued. We felt they were delaying matters dangerously; that probably our army would have to act before the Chinese had decided what to do. We knew then our lives would be forfeited. On the and October by Hangki's desire we wrote for clothes. We made a backgammon board out of a cushion of a stool; played a few games in the evening. Lovely cloudless weather-how we longed to be free and on horseback! Ten days after we had written the clothes came-only a shirt or two and pocket-hand- 
kerchiefs; a letter also from Wade to Parkes. The letter said Lord Elgin had been in communication for a week with Kung, the Emperor's brother, and now Prime Minister, but that the Chinese were so full of evasion that the army would advance and shell Peking. A long and unsatisfactory conversation ensued; the misfortune was the Chinese would not believe in the nearness of their danger. I examined the things sent from the camp carefully, and on one handkerchief found written in Hindostanee that the big guns were to open on the city in three days' time; on a shirt, also worked in silk, I found the same information, and asking us if possible to communicate what part of the city we were in. Each day that passed brought the crisis nearer; we knew our fate must be decided in three days. One day Hangki called in the afternoon and announced that there had been a most unsatisfactory discussion; that we were to be beheaded; but if we had any last letters to write he would take charge of them and call in two hours' time. When he called we had both finished our letters, and he said in the morning he would take them. But on the following day he said for the next day or two we were safe. On the morning of the 7 th the long-expected sound of guns awoke me. I pushed Parkes and was up in a moment. We went into the courtyard, avoiding, however, exhibiting any anxiety. Our jailers and guard had also turned out, and were watching us anxiously. The firing was slow and steady, but it suddenly ceased. While we were discussing what it could have been, Hangki, 
followed by other mandarins, rushed in and demanded from us the reason of the firing. We said we were prisoners, they should know best ; but probably the Chinese had delayed so long the bombardment had commenced, as we had warned them would be the case. He said our lives were in great danger, and asked us our advice. We said the only advice we could give him was to accede at once to Lord Elgin's demands. In the meantime a man had come in to say the guns were not shotted, so Parkes and I knew it had been a salute, but this we kept to ourselves. Hangki said we must go and see Prince Kung, and we afterwards learnt from his servants that the gates having been closed when the guns were first heard, he was lowered down the wall, sixty feet in height, in a basket, as Kung was at the summer palace. The day passed very slowly. Early on the 8th we sent to Hangki's house, and learnt he had returned, and would call on us in an hour. When he came he said he had seen Mr. Wade, that Lord Elgin had increased his demands, and he did not see how we were to be released. At last he informed us that he hoped we should be released that afternoon at two o'clock. We anxiously looked forward for that hour without betraying any anxiety for it. When it arrived we were placed in a covered cart together; there were four others, but we were not allowed to look into them. A large escort cleared the way for us, and we drove for the north-western gate. Knowing the soldiers had charge of it, it was an anxious moment till we saw the great doors swing open and 
heard them close behind us. We found ourselves alone with the mule driver; he said he had no orders ; we told him to take us in the direction of our army. We followed the west wall, and then below the north for nearly ten miles, the soldiers looking down upon us. The mule driver advised us to keep our heads under cover. At last we arrived at a road leading away from the north gate, and after following it for a mile we saw the joyful sight of a red coat. We jumped out, and then learnt the other carts contained the old Sikh and French officers. We were soon within our lines and were free.

"We have since learnt that the positive order from the Emperor for our execution arrived half an hour after we were released." 


\section{CHAPTER XVIII.}

FIFE ELECTION.

I 864, 2nd April._Went to Leicester; met Edward Leigh and John Bennet and went with them to Melton steeplechase. On the way Frank Goodall and Jim Bailey, Tailby's men, and Jack Goddard and Tom Firr, Quorn men (Clowes, M.F.H.), passed us, as they were to keep the ground. As Tom Firr passed, Bennet said, "That chap's legs are too thick". I think Colonel Owen Williams, Ist Life Guards, broke his leg in the preliminary canter, another horse having run against him. After the races Bennet kindly drove me to Sulby, Fred Villiers; stayed there Sunday.

On Monday, 4th, out with Pytchley at Brampton Wood, and went down to Scotland by night train. Jack Musters came down to try and buy some of the Fife hounds, and stayed at Dysart. I went out with him next morning at 6 A.M. at Woodside; found a fox and ran a bit, but had to stop, as I had to go to a Conservative meeting in Cupar. Before going into the meeting I met John Cairns and Peter Dingwall, my tenants, who said, "You will be asked to stand for the county, to oppose Sir Robert Anstruther". 
The meeting took place, and I was asked. I asked for a day to consider it, and went to Dysart that night, and next day consented. I did not like the job, as I am not a politician by nature, and had never studied the subjects carefully; but I thought it was my duty to try, as I had been requested by such an influential meeting.

The Fifeshire Journal treated me to a rare "puff":-

"The Conservative Candidate for Fife.-In Captain Thomson of Charleton we have secured the most personally popular gentleman who could be brought forward to represent the county of Fife. . . . Captain Thomson is identified with all that represents the chivalry, courtesy, enterprise and good-fellowship of the county. ... In his family extraction it is well known Captain Thomson stands on a level with the proudest houses of the district, and his connections and influence are wide and extensive. If signal and long attachment to the interests of the people, and the devotion of his talents and means to the development and improvement of the county in agricultural resources-if prominence and leadership in movements connected with the patriotism and chivalry of the district-if a character of rare and unrivalled generosity and universal courtesy-if the possession of abilities of a high order, by a man whom all other men respect, admire and esteem, can qualify for the representation of the county of Fife, or establish a claim on the gratitude of the electors, we have no fear of the result of the 
contest. If any man is entitled to ask for such an honour, and to receive it with alacrity, that man assuredly is Captain Thomson. There is almost no class of the community to whom we can turn on whom he has not established the highest of claims to consideration. The county gentlemen of the Fife Hunt cannot do less for the gallant Master of the Hounds. The volunteers, and all who sympathise in that great movement, must be proud of that splendid and far-famed corps, the Mounted Rifles of Fife; and Captain Thomson is not only the head and heart of the corps, but of the movement throughout the county. The farmers of Fife find in Captain Thomson the model landlord, who is beloved by his own tenantry, and who devotes his energies and attention to the improvement of their condition and the welfare of the agricultural classes. But is there any part of the general population that is not familiar with his pleasant face and courteous smile, as he has gone out and in amongst them, interesting himself in all their affairs, encouraging in difficulties, and keeping alive in the breasts of the poor that hereditary love and respect for the classes above them which used to characterise our land? Nor is Captain Thomson only the kind and indulgent landlord and brilliant sportsman. We know how valuable are his abilities in the conduct of the county business; how powerful and able is his mind when it interests itself with public affairs; how, banishing, as it were, by the very tone of his voice, the least approach to the acrimony of party, he nevertheless 
shows his thorough acquaintance with those great questions which agitate the minds of politicians, and his earnest desire for the furtherance of true prosperity and progress."

"To the Electors of the County of Fife, I 864.

"Gentlemen,-

"... I now, in compliance with an influential and numerously signed requisition, beg to offer myself as a candidate for the honour of representing you. I do not bring myself before you from any motives of personal ambition, but solely in the hope that my services may be of use to my native county. Although I cannot lay claim to much political experience, I have at least the advantage of having constantly resided among you, and being personally known to many of you.

" My principles are Conservative, but, at the same time, I am in favour of all reasonable progress, and would support any measure to rectify existing abuses. Believing that to be prepared for war is the best security for peace, I would vote for the efficient maintenance of the army and navy, having a due regard for the economical outlay of public money. . . .

"All matters of local interest shall have my constant attention.

"I trust to have an early opportunity of calling upon you personally, and of more fully explaining my opinions.

"I am, Gentlemen,

"Your faithful servant,

"John Anstruther Thomson.

"Charleton, 7th April, 1864." 
"Wemyss Hall, Cupar Fife, "Tuesday, 6 P.M.

"My Dear Wife, -

"Yesterday I speeched well at St. Andrews, and had a large and good meeting. I then went on to Ferryport, where I speeched badly, and only had a dozen people to talk to. I went and had some tea with Captain Codrington, and went on to Newport, where they had made a mess of the notices, and hardly any one appeared, so I told them I would come back on Thursday. I then rode into Cupar, where I arrived at 9.30. I slept at the Royal Hotel, and this morning had a first-rate meeting, but I was awfully tired. I speeched shorter, but not badly.

"I have just been to Ceres, where there were few people, and speeched fairly, and have just come up with Major Wemyss. I am going to have some dinner with him, and then go to Dysart with Tom Cartwright.

"In this country things are pretty well, but I am not very sanguine in the west. I don't know when I shall bring my bones home. John Pye takes this. Ross goes with me, and I want some clean shirts sent to Dysart, and all letters.

$$
\begin{aligned}
& \text { "Yours aff., } \\
& \text { "J. A. T." }
\end{aligned}
$$

Things in the West appeared on a nearer inspection even less sanguine than I had anticipated. In Dunfermline there were 125 voters against me, and there I decided to retire from the contest and in- 
formed my audience of my intentions in the following speech :-

"I have now visited almost every district in the county, and have received reports from the different localities; but the result of these is not such as to encourage me in the hope of ultimate success. . . That being the case, gentlemen, and after very mature consideration, I have now to inform you that I retire from the contest. To those gentlemen who have supported me I beg to return my most sincere thanks, and to express my deepest gratitude, in the first place, for the honour they have done me in considering me worthy of their confidence, and also for the great zeal and activity which they have exhibited in the prosecution of the canvass in my favour. . . To you, gentlemen, who are my opponents-although I still call you my friends-I beg to return you my sincere and grateful thanks for the courtesy with which you have received me on every occasion, and for the attention with which you have listened to me. In another place I stated that my supporters should confess that I ran the race stoutly and honestly. I can assure them that hitherto I have done so to the best of my ability, but the odds are too great against me. I am sure my opponents will confess that I have fought them freely and fairly. I have taken no part in any underhand proceeding of which I can be ashamed; I have made no statement which gives me any regret; I have used no word which I would wish to retract. I shall retire, gentlemen, into private life with very 
mixed feelings-feelings of pride, of regret, and of gratitude; - of pride, that my friends thought me worthy to represent them; of regret, that the issue of the contest by their exertions has not been brought to a more favourable conclusion; and of gratitude to you all for the kindness which you have individually displayed towards me. I can assure you, gentlemen, I now with the greatest respect beg to take my leave of you, assuring you whether in public life or in private life that $\mathrm{I}$ am ready at all times to devote myself to the good of our county." (Cheers.)

John Blackwood wrote :-

"April, 1864.

“Dear Mrs. Thomson,-

"Allow me to congratulate you and Mr. Thomson on the admirable appearance he made at Cupar. It was an uncommonly clear and telling statement. I had anticipated your feelings about the want of support in the press, and tried to rouse Ayton to take you in hand, and he had promised to try. I wrote to him and sent a file of papers, but the same evening came the news of the withdrawal. I suppose it was wise.

"In fact, we had been out of office for fully thirty years, and Scotsmen do not become converts to a party in that position. I hope, however, Mr. Thomson will try again, when there is time to work up the constituency and things look brighter.

"Believe me,

"Yours,

"John Blackwood." 
Having made my last speech and withdrawn from the contest, I breathed more freely. I hated the whole business, and I was awfully tired and had a buzzing in my ears, from which I have never recovered. George Whyte-Melville wrote "congratulating me on not becoming an M.P."

I wrote to my father-in-law :-

$$
\begin{gathered}
\text { "Charleton, Colinsburgh, } \\
\text { " igth April, i864. }
\end{gathered}
$$

“My Dear Mr. Gray,-

"I received your letters yesterday, and all your remarks about the election are very just. The Conservative party have done nothing either to improve the registration or to keep the party together, and they started in the mistaken hope that my personal popularity with the farmers could counterbalance the Radicalism of the ten-pounders. The other party have a thoroughly well-organised system - every shopkeeper, every foreman of works, is put on their working committees, and thus influence the others. Another advantage they have is, all the cheap newspapers are Radical, and the Scotsman newspaper and McFarlane, the agent at Dunfermline, could almost return the member without other assistance. There was a majority of 125 against me in Dunfermline, pledged, which it would take twenty rural parishes to counteract. Another thing is, many of our agents are not men of real good character.

"As for my own part, I had never given a serious 
thought about it, and I never spoke for ten minutes in my life except on convivial occasions. I had been out hunting in Northamptonshire in the morning on Monday and travelled down during the night, and on arriving at Cupar found myself $i n$ for this business. I was not fit for it-either bodily or mentally. I had to cram Acts of Parliament from daylight till dark. However, I have nothing to regret in it, but I have little hopes of the future.

"As to the Kilmany Free Church, it was a case of aggression on their part. There was one member of their congregation in the village of Kilmany, ninety in the village of Gauldry, and ninety in the village of Logie, where the Free Church is situated. They wished to pull down the church at Logie and put it up near Kilmany, so that 180 would have to walk one and a half miles to meet the one member. I offered them a site at Gauldry, but that would not suit them. Any impartial person can judge how reasonable their request was.

"As to your question about influence: Mrs. Durham, right, very (Durham of Largo); Simson, a very kind letter saying he would not vote against me (of Pitcorthie); Lindsay, no answer, as far as I know (Balcarres); Bethune, I should think against me (Kilconquhar); Douglas Irvine, right (Grangemuir); Stewart (St. Fort), right, but his son very active on the other side. Most of the tenants, therefore, would not vote.

"Now that this M.P. business is over, the negotiations about M.F.H. for Pytchley have recom- 
menced, and we are likely to come to a more successful conclusion.

"Mr. Kinnear has written thanking me for the remarks I made about him, and the bosh that was talked about the impropriety of his address being issued before Wemyss' funeral.

"I have just had a letter from the photographer at Leven asking me to sit to him, as he had thirtyfour orders for my photo by Saturday's post, so I am going to ride over with the boys.

"I have sent Mr. Parker to attend the nomination and report what takes place.

"Love to Mrs. Gray.

$$
\text { "Y. Anstruther aff. }
$$

I then began again to turn my attention to the duties of a M.F.H. There had been an idea of reducing the number of hunting days in Fife and selling half of the pack. The hounds were the property of the committee-Lord Rosslyn, Mr. Balfour, Mr. Haig, Mr. Oswald, Mr. Hay Paterson. There was a debt of $£_{500}$ on the hounds, and the interest of that sum was the first payment from the subscription.

"At a meeting at Cupar, on 3oth April, I864, Colonel Thomson moved that a joint-stock company be formed for the purpose of purchasing the Fife Hounds, and forming a county pack, in shares of $£_{25}$ each, and that a committee of gentlemen be requested to act for obtaining shareholders and subscriptions 
and purchasing the pack, which was unanimously agreed to. At a subsequent meeting on 5th July, 1864, the following gentlemen agreed to take shares :-

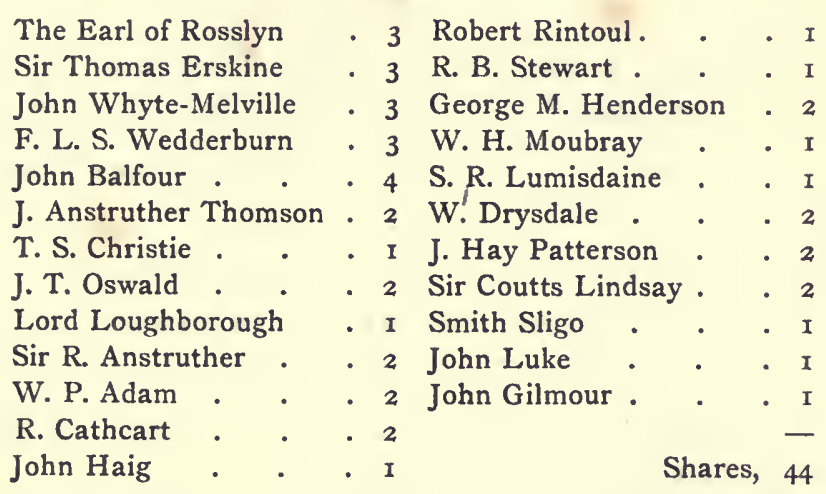

"I. The shares shall be fixed at $£ 25$ each, and the money raised thereby to be employed in purchasing the Fife pack of hounds, which shall be the sole property of the shareholders.

"2. The hounds to be kept in Fife, at such place as the committee of management shall think proper.

"3. The pack to be maintained, and the expense of the hunting paid, out of annual subscriptions to be raised for the purpose.

"4. A Master of the Hounds and committee of management to be named by the shareholders, who shall take the charge and management of the pack till otherwise arranged. Colonel Babington to be Master of the Hounds, and the committee to consist VOL. I. 20 
of Mr. Whyte-Melville (convener), Sir T. Erskine and Mr. Oswald - any two a quorum - and Messrs. W. and G. Pagan to be hon. secretaries and treasurers.

"5. General meetings of shareholders shall be held on the first Tuesday of February and first Tuesday of April in each year, for the purpose of transacting all necessary business.

"6. Any shareholder may assign his interest in the hounds, but only to a person to be approved of by the remaining shareholders at the meeting to be held on the first Tuesday of February.

“7. Each shareholder shall have a vote for every share he holds at all meetings, and in all matters connected with the company.

"The secretaries and treasurers were also instructed to apply for a lease of the New Inn kennels for one year."

It will thus be seen that a sum of $\measuredangle \mathrm{r}, 100$ was raised in forty-four shares of $£ 25$ each, and the committee purchased the pack for the shareholders from the then proprietors for $£ 800$. Colonel Babington became the master, with Ben Painting, huntsman; Jack Shepherd and George Ferguson, whips.

When the Fife Hounds became a subscription pack in 1805 , my father got a copy of the rules of the Pytchley Hunt. 


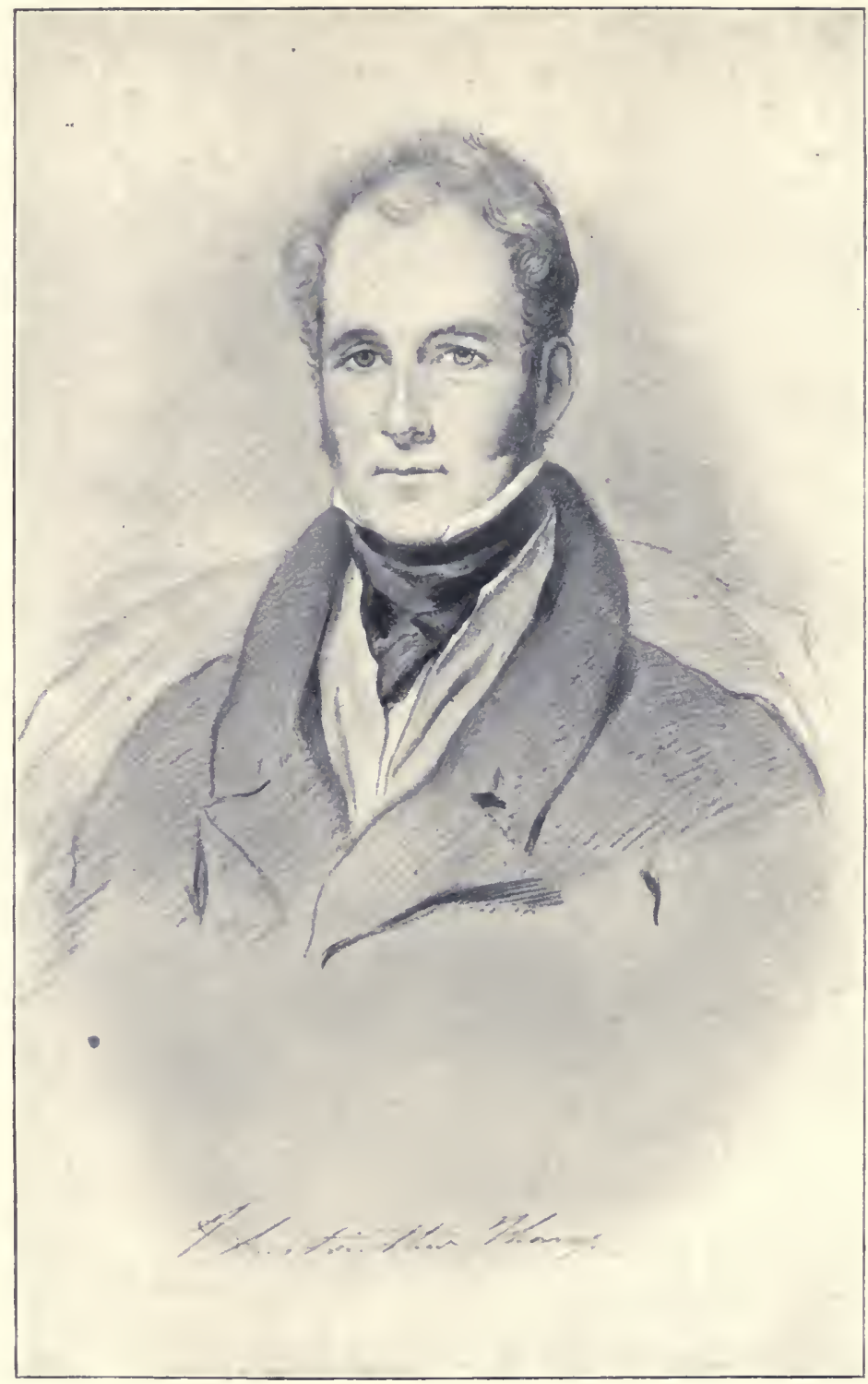

JOHN ANSTRUTHER THOMSON OF CHARLETON (1830).

(MY FATHER.)

From a Painting by Colvin Smith at Charleton. 

Rules and Orders of the Pytchley Hunt settled at several Annual Meetings in London.

"I. That the number of members of this hunt be limited to forty.

"2. That the members be chosen by ballot.

"3. That no less than eight members shall be present to ballot at the annual meeting in London, when two black balls shall be sufficient to exclude any candidate; and that it be allowed to ballot for any candidate at Pytchley House, twelve members being present, and one black ball to exclude, provided such candidate be put up a week before the ballot.

"4. That the annual subscription be ten guineas.

"5. That every new member do upon his election pay ten guineas to the treasurer, in addition to his annual subscription.

"6. That every member absent from Pytchley do stand at a shilling a day during the meeting.

"7. That any member being in England, and not appearing at Pytchley House once in the season, shall forfeit three guineas.

"8. That every member not appearing at the annual meeting in London shall forfeit one guinea; and if in town the day of the anniversary, two guineas.

"9. That any member be at liberty to bring one visitor to Pytchley, and to place him in any 20 * 
vacant room, till it shall be wanted by a member of the hunt.

" Iо. That no new rule be made in this club except by ballot.

"Thatched House, "2gth May, I802.

"Resolved (nem. con.),-That each of the members of the Pytchley Hunt do pay in addition to the present year's subscription, thirteen pounds for the purpose of repaying Mr. Christopher Smyth the money advanced by him on account of the hunt.

"Resolved,-That all members are considered as belonging to the hunt for the ensuing year, unless they shall give notice in writing to the chairman of the anniversary meeting, held the last Saturday in May, of their intention of withdrawing their names.

"Resolved,-That the treasurer be empowered to use all necessary means to recover all arrears due to the hunt, and that the additional subscription and all arrears be paid to Christopher Smyth, Esq., at Northampton; or to Messrs. Drummonds, Charing Cross, to Mr. Smyth's account.

"Resolved,--That Mr. Isted be appointed treasurer to the hunt.

" Resolved,-That the foregoing resolutions, and a copy of the rules and orders of the Pytchley Hunt, be sent to each member of the club. "Present, and signed,-Spencer, T. A. Smith, 
J. Dorrien, Henry Warde, Wm. Davy, Wm. H. Fellowes, J. Warde, R. L. Doughty, J. Thursby, R. Andrew, W. R. Cartwright, E. Bouverie, Samuel Isted.

"Lord Spencer subscribes $£ 400$ per account to the hounds; Mr. "Warde keeps them and pays the remainder. Pytchley House is also given by Lord Spencer gratis; Mr. Warde keeping it in repair. The hounds given to the huntsman of the Meynell Hunt by Lord Sefton are sold at three guineas; the others disposed of are to the account of the hunt. Some Lord Spencer gives in present."

The following interesting letter was written by Charles Maitland Christie of Durie to my father :-

“Melton, 28th January, 1822.

"Dear Thomson,-

". . . I have seen a great deal of excellent sport, within twenty-five miles of this place, with the Duke of Rutland's, The Quorn and Lord Lonsdale's hounds. The two first are by Melton men voted the crack packs, but Lord L. generally gives a better account of his foxes than either of them. There is generally a larger turn-out with the two first than with Lord L., and the lads of character prefer going with them, consequently the hounds are more over-rode and more foxes are lost. A horse soon learns to jump here, for he must be constantly at it when with hounds, but the fences in general are easy, not however without many exceptions. There are great tracts of country quite delightful, large 
grass fields with good footing close up to the fences; you jump from one carpet on to another, and with a straight-running fox and a good scent the sport is superb. Riding is the whole business here almost ; very few care a — about the hounds, and provided a man can show himself forward, he does not care, and often does not know, whether it be with a scent or without one. I have repeatedly seen the Duke's hounds go about a mile without a scent, flinging a little for it certainly, but so pressed upon by the sportsmen that away from it they must go. The Duke, vulgo Don Dismal, rides by himself at a distance when there is a large field out, but performs tolerably well sometimes when the field is small.

"Lord Elcho had a bad fall last week. His right shoulder is still so much swelled that the surgeon does not know whether the collar-bone is broken or not. $\mathrm{He}$ is an excellent fellow, and more generally at head than any man in Melton. I hope with all my heart he will soon be leading the field again.

"Now that I have seen all the wonders of Melton riding, I am going to study hunting under Chaworth in Northamptonshire. I expect to see in him the ne plus ultra of a sportsman. Should I have the pleasure of hearing from you again, direct to Post Office, Northampton. I had a letter the other day from Kintore. He tells me they killed a lot of foxes, but had very little running across the country. I was glad to hear that Crane was giving satisfaction; 
he appeared to me to be a very good horseman, but rather fond of a jump. I think I shall be home in a month or so, particularly if the country gets too dry to carry a good scent. Adieu.

"Yours very truly,

"Chas. M. Christie." 


\section{CHAPTER XIX.}

PYTCHLEY.

I RECEIVED on 27 th February the following letter from George Whyte-Melville :-

\section{"Wootton Hall, Northampton, "26th February, I864.}

“My Dear Jack,-

"Under the influence of a ripping fifty minutes over grass, up wind, and all just as it should be, I write you a line as a feeler about our country. I have only just heard that you have really given up the Fife Hounds.

"I know your tastes so well that I am quite sure that you would not be yourself without a pack of hounds; and, indeed, the longer I live the more I find cause to agree with Jorrocks, that 'all time is wasted that is not spent in hunting'. Now do you think you would like this country? We shall have no master after this season, as Spencer has quite decided finally to give them up. You know the advantages and disadvantages of this country of the Pytchley as well as I do. It has the best woodlands in the world, and you can hunt from August till May, both inclusive, as they say. The disadvantage is the crowd on a Wednesday, which 
you also know from experience with the Atherstone, and I am sure you will agree with me that a crowd does not do half the harm it appears to do. If there is a scent they are soon disposed of ; and if there is not, you must feel your way at any rate. From what I see I think if you were to take our country you would be very well supported, though I am not writing under authority, but only between you and me. We have a capital pack of hounds, although it is the fashion to abuse them. They hunt as well as they run, and there is no doubt about the latter quality.

"I think you would enjoy the riding over these grass fields as much as the hunting in the deep woodlands on the Kettering side. This is a long stave, and like one of Lord Russell's.

"Don't tell Mrs. Thomson I am trying to tempt you here or I shall be in disgrace with her; and, of course, if you did come to us, nobody in Fife would ever speak to me again. I should much like to see you here, but that, I fear, is as much from selfish and 'mahogany' motives as from my good opinion of your rat-catching qualities. I should like if it could come off. Ever my dear Jack,

$$
\begin{aligned}
& \text { "Yours very truly, } \\
& \text { "G. J. Whyte-MeLvilLe." }
\end{aligned}
$$

About the same time that I received George Whyte-Melville's letter, I received one from John Darby saying that if I would take the Pytchley Hounds he would mount me the first season for 
nothing. I thanked him and said that arrangement would not do; but I bought a good many horses from him. I also had a letter from my old groom, John Whitehall, who was leaving Lord Stamford, wishing to come back to me. He had $£ 200$ a year with Lord Stamford. I engaged him at $£$ I 20 per annum.

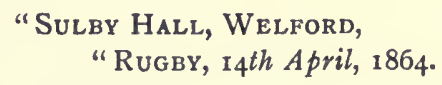

"My Dear Thomson,-

"I have heard this morning from Suffield, who absolutely and finally declines the hounds. If you are disposed to honour us by being our master, would you send me a letter stating your views, such as I can show to the members of the hunt.

"We have deferred our hunt meeting from Wednesday 2oth to Saturday 23 rd, at Northampton at 2 P.M. The hounds hunt at Brampton Wood, for the last day, on Friday 2 2nd.

"If I can get the members of the committee together, I will try to get a sort of official invitation to you in the meantime. But from the feeling shown when your name was mentioned at the last hunt meeting, I am quite sure you would be very acceptable to us.

\section{"Yours very truly, \\ "Fred VilLiers."}

George Whyte-Melville was the secretary, and F. Villiers was the chief man on the committee. Lord Suffield had been mentioned as likely to take the hounds before I came into the field, but withdrew. 
I wrote to Payne proposing that he should hunt one pack and I should hunt the other. $\mathrm{He}$ replied :-

" 17th April, 1864.

"SIR,-

"Respecting the Pytchley country and your offer, after hunting this country so many years. as I have, I cannot entertain such an arrangement I could not go into it with the sport a man ought to do, therefore I must decline it. . . . Mine has been a hard-fought battle for eighteen years with the wildest field in England-heart-breaking to a good sportsman. Well does poor Lord Spencer know this, who, I am very very sorry to say, is far away, or I am quite sure he would have arranged the thing satisfactorily for me before this.

"There I must leave it, sir, but not without thanking you for your kind letter.

"Your most obedt. servt.,

"Chas. Payne."

I wrote to Villiers :-

$$
\begin{aligned}
& \text { "Charleton, Colinsburgh, } \\
& \text { " 25th April, i864. }
\end{aligned}
$$

"Is the matter so far settled that I may give up my hold on this country and begin to engage servants? Not a moment should be lost now, and if I have to wait another fortnight I shall lose my groom and all the good men will be disposed of, and I suppose Payne will want a second whip. Can you, the committee, settle with me, or must you refer to another general meeting? 
"The object of my telegram was to get a positive ' $Y e s$ ' or ' $N o$ ' now, for I should be in a mess if I engage servants and have not the country, and in a worse mess if I have the country and no servants, which will be the result if I have to wait longer. If your answer is right, I will go up and see Payne. I have written to him again."

I wrote again to Payne only proposing to engage him as huntsman.

"Sir,-

“ 27 th April, 1864.

"I shall be very pleased to enter your service as huntsman upon the same terms as I am at present, and will do everything in my power to give you satisfaction. I could not possibly go back to two days a week; I would rather hunt six....

"I am sorry to say we have had distemper very bad; has left us very short; shall require three or four couple more than I have.

"Your most obedt. servt., "C. Payne."

The next thing was to find a house. Pitsford had been the residence of many former mastersGeorge Payne, etc.-and was now the property of Lord Overstone. I wrote to Bob Lindsay, his sonin-law, the late Lord Wantage. He replied :-

$$
\text { "gth May, } 1864 .
$$

"I have had a conversation with Overstone with regard to Pitsford House, which has only lately 
become Lord O.'s property, and which I believe he very much regrets ever having become possessed of. He bids me say that such as the house is you are welcome to make use of it. $\mathrm{He}$ has never been inside it, and knows not how much or how little it may require doing to.

"That he is not prepared to lay out money upon it, but that as long as you choose to live in it you are welcome to do so, and that he will require nothing but a nominal rent. If you go to see Mr. Beasley, I am sure he will be ready to do all in his power to assist you.

\section{"Yours very truly, \\ "R. Lloyd Lindsay."}

Mr. Beasley was very obliging. The rent was fixed at $£_{30}$ per annum, and the field $£_{12}$. The field contained many splendid walnut trees.

The house was a hideous, square place, with no ornament, and very inconvenient. On one side, about thirty yards off, was a brew-house; on the other side, a stable for four horses, and rooms above it. I made the brew-house into four rooms for the boys and their tutor, Mr. Parker, and a school-room, and joined it to the house by a covered passage. I spent about $£_{300}$ on the place. I only occupied it two years. It was about one and a half mile from Brixworth by road, and there was a shorter way by footpath, and continually we were at cross purposes, a message coming from the kennel by the footpath while I had sent one by the road. 
"Sulby Hall, Welford,

"27th April, 1864.

"My Dear Thomson,

"Yours of the 25th just reached me. I fear the committee cannot give you a positive answer previous to the meeting. But you may feel quite certain that we shall be able to give you the $£ 3$,000 for which you asked, taking upon ourselves the rents and repairs of coverts. I have a telegram this morning from Lord Spencer dated 25th: 'Arrived at Constantinople to-day; will give subscription to Thomson if Suffield has not changed his mind'. This answer, as Suffield has quite withdrawn, makes the amount of subscription reaching $£ 3$,000 for you quite safe.

"I imagine that Spencer answers a letter of mine, and not Melville's telegram, because in my letter, which was written when Suffield withdrew, there was no allusion to Harleston, and the telegram alluding to Harleston was sent in Melville's name, and the answer would probably be sent to him.

"You will be asked to accept the following conditions: (I) To agree to hunt the country four days a week, weather permitting, during the regular hunting season; (2) To leave the pack in as efficient a state as you find them. If you are prepared to agree to the above conditions, you may in my opinion decidedly consider the matter settled; but of course I can only say this as an individual.

"It has always been the custom for the new master to write and ask permission of the owners of 
coverts to draw them. I have a list of them ready for you. This is really only a matter of form, as I do not know of a single objector in the whole of the Pytchley country. If you and the meeting close your bargain on the 7 th (I can see nothing on our part to prevent this happy conclusion), the abovementioned circulars are only matters of courtesy.

"I am very sorry there has been so much delay, but circumstances have rendered it unavoidable. Just off to London.

"Yours very truly,

"Fred Villiers."

7th May, 1864.-I sent out the following circular :-

"SiR,-

BRIXWORTH, gth May, I864.

"I have the honour to inform you that I have undertaken the management of the Pytchley Hounds for the ensuing season. I therefore beg to request that you will grant me permission to draw your coverts in the usual manner.

"I have the honour to be,

"Your obedient servant,

"J. Anstruther Thomson."

I wrote the following to my wife :-

$$
\begin{gathered}
\text { "Rugby, } \\
\text { "Jack Darby's, Wednesday. }
\end{gathered}
$$

"Old Whitehall had the English cholera and was in his bed, so did not turn up till last night, and I did not see him till this morning. $\mathrm{He}$ is delighted 
to come back, and the sight of him did me good. I want to get two or three of Spencer's horses for Payne, so I am going up to London to-night, and shall come down to-morrow night."

Whitehall came up to London and brought a bundle of letters, my circular having produced twenty-four civil little notes in reply. I met Cardigan in the park: "By all means, by all means. The oftener the better; I need not send you any further reply-the oftener the better," with his usual flourish.

Duke of Buccleuch's letter :-

"London, I8th May, I864.

"My Dear Thomson,-

"I have received your letter informing me that you have undertaken the management of the Pytchley Hounds for the coming season, and requesting me to grant you permission to draw my coverts in the usual manner.

"I am most willing that you should draw my coverts, but not in the manner which has been usual of late years, which has been to draw the woods a few times in the autumn and in the spring, and almost entirely to neglect them during the greater part of the hunting season.

"This neglect has given the greatest dissatisfaction in that part of the country; has been the cause of the Pytchley Hounds losing a considerable portion of the woodlands; and if it were not for the protec- 
tion foxes receive in my woods, there would be very few indeed in that part of the country.

"Believe me, yours most sincerely,

"BucCleuch.

“J. Anstruther Thomson, Esq."

"My Dear Mr. Tryon,-

"I shall have much pleasure in complying with your wishes that the Fitz-William Hounds should have permission to draw your coverts during my mastership of the Pytchley Hounds.

"I will report to you our proceedings after being at Bulwick on Tuesday next.

"I sincerely hope that you may make a speedy recovery, and that we may soon see you at home again.

"Believe me,

“J. Anstr. Thomson."

I wrote to my wife :-

"ONSLOW SQUARE,

"Tuesday, 26th May, 1864.

"Well, yesterday I picked up Percy Williams in a cab at ten o'clock, and went to dog show. I there met John Fletcher. He, Percy Williams, and I were judges for fox-hounds; Lord Suffolk and G. Moore for pointers; Charlie Leslie and Carr for mastiffs and Newfoundlands; Lord Bury for staghounds. I don't know who else, but we were in pretty good society. It is very well managed, but our space was too small. Percy and I in our kennel coats were standing over two young hounds. VOL. I. 
On looking up I saw all the people with their hats off, and a pretty girl with rather a sharp nose gazing through the wires at us. We pulled off our hats, and stood at attention, and looked straight in the faces of the prince and the princess. I could not help laughing. They walked all round our cage, and as they passed us the prince took off his hat to us. Old Barnett (Cambridge Hounds) was there, and the prince knew him, having hunted with him, so we walked round with him and told him what was what. II need not tell you who got prizes, as you will see all that in the papers. We were at it all day, and had a good luncheon in the secretary's room, and all the huntsmen were entertained also. At four the public came in, and then we looked over the hounds again and gave our decision, having previously made up our mind. We were unanimous on every point, which perhaps is a proof we were right. I know we were not far wrong, as all the huntsmen appeared satisfied, and they are the best judges. At $7.30 \mathrm{I}$ got into a cab and drove to the Albion, dressed there, and dined with the 9th (Lancers); Rosslyn in the chair. I sat next John Madocks.".

The Duke of Beaufort sent twenty couple of hounds, which he had taken to France to hunt wolves. When I asked Tom Clark if he had learned to talk French, "Prenez garde des chiens sil vous plait, messieurs," he replied. I asked him how they got on travelling. He said, "Oh, we had a currior." 
The kennels were very confined, and in the village at Brixworth; only one field to walk out in ; a nice house for the huntsman at the end of the field. The stables were in a courtyard, with a dungpit in the middle, and on frosty mornings it was full of fog from the steam from the pit. There were no drains in the stables, but a grating and a cesspool in the middle of every stall; but still the stables were very healthy. I soon removed the dung-pit to the other side of the road, and the committee built a house for Whitehall in the yard.

The hounds belonged to the country. Percy Williams came and looked over them in June I864. The hounds were good looking, with nice necks and shoulders, but very light of bone, especially the bitches. In chase they were excellent, and not a bit afraid of the horses, but with a bad scent they were not diligent. In gorse cover, when they found, after running a few times round it, they would stand at a "smeuse" in the fence till holloaed away, then rush out, race the horses, and in two fields would be all together in front.

John Whitehall had charge of the horses at Brixworth; John Pye had charge of those at Pitsford, two carriage horses, "Charm" and a hack.

I brought from Fife "Highlander," a grand horse $16^{\circ} 3 \frac{3}{4}$ high ; could jump anything and go on all day. "Kathleen," a capital mare; kicked every stride when ridden on the way to cover. "Dentist," a tremendous horse to plunge; when any boy came applying for second horseman's place, he had a ride 
on "Dentist". Mrs. Payne wished her son to get the place, but when she saw "Dentist" she retracted. "Phœbus," a roan stallion; sold to John Spicer for $£ 200$, afterwards at Badminton for many years. At one time there were eleven roan fillies there by him. "Valeria," a chestnut mare which I bought from Bob Cathcart.

I bought "Rigoletto" at Lord Spencer's sale, as Charles Payne had ridden him. I bought a lot of cub-hunters from John Darby at Rugby. After cub-hunting season, sold them at Birmingham. It was a bad day and bad sale; lost a lot of money on them- -88 o. On mentioning it to John Darby he deducted half $(£ 40)$ off my account.

I engaged Payne as huntsman. He had been eighteen years with the Pytchley and had almost been his own master, and he did not look on my arrival with much satisfaction. He was a very smart-looking man, with a very curious sharp way of speaking. He was a first-rate horseman, no better across Northamptonshire, but he was not a first-class huntsman-not to compare with John Walker, old Will Goodall, Tom Firr, Will Dale or young Will Goodall. He was a galloping huntsman, and depended a good deal on the assistance of his first whip, Jack Woodcock, who was often on the top of the hill in front of him. He had little hound language, and not a very good voice. "Hooyier," he used to cry to get his hounds to him. He was not an affectionate man to his hounds, and never made friends with them. Captain Mildmay Clerk being 
asked if the hounds liked Payne, replied, "They hate him". The hounds were capital in chase, but with a bad scent they did not half get on, and bumbled about like pointers.

Payne had a pretty considerable idea of his own importance. On being asked who the new master was to be, he said, "It don't matter, if he has plenty of money-I can manage the hounds". He had perquisites of all sorts, $£$ г 30 wages, $£$ ro for clothes, $£_{9}$ for drugs, $£_{9}$ for milk for the puppies, bones, hides, and draft hounds, and silk lashes and thongs for whips, every quarter.

On going into the' kennel one morning I noticed that there was no sign of milk in the trough in which the puppies were fed. On speaking to the feeder, he said, "They do very well without milk if the flesh is fresh". When I met Payne I said, "Charles, how much milk had the puppies this morning?" "Milk, sir; oh, sir, not much, sir." "But how much?-a gallon?" "A gallon, sir, no, sir, not a gallon." “Well a quart?" “No, sir, not a quart, sir." "Had they any?" “No, sir." "Why not?" "Please, sir, my cow has not calved." "Very well ; I will have a cow of my own. Let me know what you consider the amount you receive altogether." He gave me a memorandum amounting to $£ 260$. I said, "You have put it rather too high. I will give you $£ 250$ and no perquisites of any sort-everything belongs to me." He accepted this.

I bought a little Welsh cow and put it into the kennel-field. Some time after my wife went to visit 
Mrs. Payne, and seeing the cow in the field, she said, "You are more fortunate than I am, Mrs. Payne, for I have not yet got a cow." "Oh, it only makes $4 \mathrm{lb}$. of butter a week, and I don't think it's no better nor lard."

I engaged Dick Roake as first whip; he had been second horseman to Mr. Tailby. He was a most respectable, well-educated man. He was a fair horseman, but not a very strong man. He was very attentive and worked most loyally with me. Harry Jennings was second whip. He was a fair horseman and a steady, good servant, but he had a nagging way with hounds. Payne said, "He was a worriting fellow". But he liked him so well he took him to Wynstay when he went there.

At the meeting in May, 1864, it was settled that I was to keep a huntsman, and hunt four days a week. That the subscription was to be $£ 3,000$ per annum; rents and repairs of the kennels to be paid by the country. Captain Clerk took charge of the covert fund. In July I made an amended offer that we should hunt five days a week, and I should receive one-half of the surplus subscribed over and above the $£ 3,000$. At last it was settled that we should hunt five days a week; Payne to hunt three days in the open, and I should hunt two days, one in the forest on Tuesday and Saturday alternately.

It was necessary to get some more hounds. I got a draft from Lord North, Warwickshire; Tom Mathews was his huntsman. A draft from Lothian, Alexander Kinloch and David Baird, masters; John Atkinson, huntsman. A good many of the 
hounds were from Lord $\mathrm{H}$. Bentinck. Lord Portsmouth gave me two very good bitches. I brought four couples from Fife. I bought the Pytchley draft from Payne. We also got some young hounds from George Carter, Milton kennel.

I got Joel Dunsmure as second horseman. $\mathrm{He}$ had been with me in the Bicester country; the best second horseman I ever saw, long, thin and light, but he was not steady. One day, at North Kilworth, I sent him to get a shoe put on, and passing on my way home I found him fast asleep by the fire in a public, and drunk as an owl. I took away his red coat, and left him there, and led the horse home. I never saw him again.

"London, 26th July, 1864.

"My Dear Thomson,-

"I have this morning received your letter of the 2 Ist, and have written by this post to my agent at Boughton to inquire as to my tenants undertaking to walk somé puppies.

"I expect to be at Boughton on my way" to Scotland, and 'will' see 'what can be arranged ; but there is so much dissatisfaction on account / of the woodlands being left" unhunted during the greater part of the year, that I do not expect they will be much inclined to take any puppies.

"It is not your fault if this should be the case, and I regret much that your efforts to hunt the woodlands regularly throughout the season should have met with so decided a check. 
"If the gentlemen who hunt with the Pytchley Hounds in the open will not agree to any arrangement by which the woodlands can be properly hunted throughout the season, I shall be forced at last to withdraw my coverts from the Pytchley, and make arrangements with some other pack of hounds to hunt them with the rest of the woodlands.

"Believe me, yours sincerely,

"BuCCLEUCH.

"J. Anstruther Thomson, Esq."

"My Dear Duke,-

"I am happy to tell you that I have carried out my plan of hunting your woodlands. I have gone down every Tuesday, and almost every time have had a fair day's sport and got a fox. There are lots of them everywhere, and I have met with the greatest attention and assistance from all your people.

"I have a favour to ask of you, and I hope that you will not consider me presuming in doing so. Hitherto I have travelled up and down with the hounds myself and always had twelve hours of it. After this week I intend to van the hounds down. May I put the horses up at Boughton?

$$
\text { "Yours, J. A. T." }
$$

"Bohill, Selkirk, " 3 oth November, 1864.

"My Dear Thomson,-

"I found your letter of the 27 th on my return home from hunting yesterday, and am very glad to hear you have carried out your plan of 
hunting the woodlands regularly, and have had fair sport with plenty of foxes.

"You are most welcome to have the stable-room you ask for at Boughton on the days you hunt in the woodlands. I write by this day's post to Mr. Pain, my agent, to have all things in order for you.

"My Hounds have had fair sport this season, and occasionally a very good run. I have only been out twice myself as yet, yesterday-a pretty long day-twenty-four miles to Spottiswoode, and fully thirty-eight miles to ride home.

"We had a very pretty hunting run over the muirs to Longformacus and on to Cranshaw into a large covert in Lord Wemyss' country, and the scent failing, we lost the fox.

"I should mention to you that there will probably be a party at Boughton to shoot all my coverts for a week, from Monday, I 2 th December, and do so that you may make your arrangements as to hunting.

"Believe me, yours most sincerely,

$$
\text { "BUCCLEUCH. }
$$

"J. Anstruther Thomson, Esq."

" HOARCROSS,

" 2oth November, I864.

"My Dear Jack,-

"How are you getting on, and how do you like your country, field, etc.? I have heard that you have had some sport, but I should think the hounds must have had it to themselves, as your big fields and awful fences must have been impracticable in this iron age. Even this part of the world, 
where we can creep as much as jump, is only barely rideable, and before the last two days it was fearfully hard. How do you like the hounds and Charles Payne? I heard from Harry that you would like to know if I had anything to part with in the dog line. I have two-a two-year-old dog, 'Bluecap,' very ugly, but a very hard worker, and 'Graceful,' rather a fine young bitch. They both want plenty of work to keep them steady, as they are apt to be in a hurry. If you care about them they are much at your service.

"We have done very little; our scents lately have been very poor. We were obliged to give up cub-hunting for a fortnight, as all the hounds' feet were raw. I am very sorry to hear a bad account of Lady Harriet St. Clair. How is her knee?

"Pray remember me to Mrs. Thomson and, "Believe me, "Yours very sincerely, "Hugo F. Meynell Ingram.

"You don't know of a horse in your country that would carry Tom Leedham?"

"Cross Hayes,

"BURTON-ON-TRENT, I864.

"My Dear Jack,-

"It is ages since I heard from you. I should like to know how you are getting on in the 'shires,' and whether the flying columns you command are in decent order or no. What kind of scents 
have you had? I heard of your killing heaps of cubs, so I suppose the raw material abounds. I send you a list, which I have marked with a few marginal notes.

"We have done tolerably well as yet and had a few little gallops. We have a loss in Jack, who is laid up with bronchitis, which I fear will shut him up most of the season. My father is better than he has been, but still suffers from his leg at times. I have been in Cheshire for a few days, and I don't think even your field can beat the scampering gents of that land. On Wednesday we had a good day, beginning with a very fast fifteen minutes, in which one man broke his collar-bone, one his arm, one his horse's back; one was in bed when I left yesterday from a fearful shake; Grosvenor himself had a tumble and lamed his horse, and Lady Constance hurt hers very badly. I never saw so many falls in my life.

"We are in our new house, which I shall be proud some day to show to you and Mrs. Thomson. I know it is out of the question to ask you now.

"Pray remember me to her, and believe me, "Yours ever,

"H. F. Meynell Ingram."

"Skeffington Hall, "LEICESTER, I2th December, 1864.

"My Dear Thomson,-

"I think you will find on inquiry that you have been misled as to the neutrality of the Husbands Bosworth coverts. Marston Wood and 
the Owthorpe Hills are neutral between the Pytchley and the Quorn countries, but all coverts north of the brook, like coverts in the parish of Bosworth, I have always understood to belong solely to the Quorn country.

"I have consulted many farmers and the oldest inhabitants on the subject, and they all say that Bosworth Spinnies like other coverts in that parish belong solely to the Quorn country.

"I am sure you will excuse me wishing to set you right on this matter, and you will also be glad to hear that we found a fox on Owthorpe Hills to-day, although it had been disturbed on Saturday.

"Believe me,

"Very truly yours, "W. W. Tailby.

"P.S.-As a slight confirmation of the above, I may add that the fees for each stopping at Bosworth Spinnies are included in my account.-W. W. T."

"14th December, 1864.

"My Dear Tailby,-

"I received your letter yesterday, but I did not get home till the post had gone. I must thank you for the very moderate and gentlemanlike manner in which you have stated the case of my supposed aggression. I asked those gentlemen who were most likely to know, and all agreed that the Pytchley Hounds are entitled to draw all the Spinnies in the lordship of Bosworth; and the point which requires explanation is how the Quorn ever acquired the 
right to draw Owthorpe Hills. However there is no doubt of that fact, and at present I can express no further opinion whether I was in error or not. I must express my regret for having done what was apparently a very unneighbourly act in drawing Owthorpe Hills a few days before you; but I had given Payne orders to draw them, and we were on our way there before I knew that you were to meet at Teddingworth on the Monday following. Luckily we found directly, and did not disturb a great part of the covert. I will take care that it does not occur again, and I hope you will find me a good neighbour in every respect.

$$
\begin{aligned}
& \text { "Ever yours, } \\
& \text { "J. A. T." }
\end{aligned}
$$

I got on very well with Payne through the season, but his ways were not always my ways. At the end of the season he heard that John Walker was going to leave Sir Watkin Wynn, so it occurred to him that Sir Watkin's hounds would be a desirable cross with the Pytchley. He took some bitches and went down to Wynstay and looked round the place and made inquiries. A few days after this I received a letter from Sir Watkin.

"Wynstay, April, I865.

"Dear Jack,-

"Here I am with my head tied up, just recovering from the mumps. Seen old Walker two good days this week; he is cheery, but, poor old man, 
he feels this is his last season. I had a letter from George Fitzwilliam saying that he was going to keep Carter on, and hear Lord Fitzwilliam has offered him his place. Will you tell me, is Charles Payne to be talked to or not? He has been down to see the kennels, etc., here. I was out, as I went off very early to Quarter Sessions. I did not know he was stopping, or he might have had a day's hunting on Friday. Will you write me a line on huntsmen in general.

"Yours sincerely,

"W. WYNn."

I then wrote to Payne:-

"PAyne,-

" Pitsford, Northampton,

"April, r 865.

“I have received a letter from Sir. Watkin Wynn in which he says,' "This is Walker's last season; tell me is Charles Payne to be talked to or not; he has been down here to see the kennels, etc. I was out and did not see him, etc.' I am anxious that there should be no mystery between you and me, so. I send you a copy of my answer. 'With regard to Charles Payne, you are welcome to speak to him: He is a thoroughly respectable man, and I have found him very attentive and willing. I have not quite made up my mind as to next season, as my eldest boy is not strong, and may require a warmer climate. I should like to go on, and if I do, 'I think a change may be desirable, though I have got on very pleasantly with Payne.' 


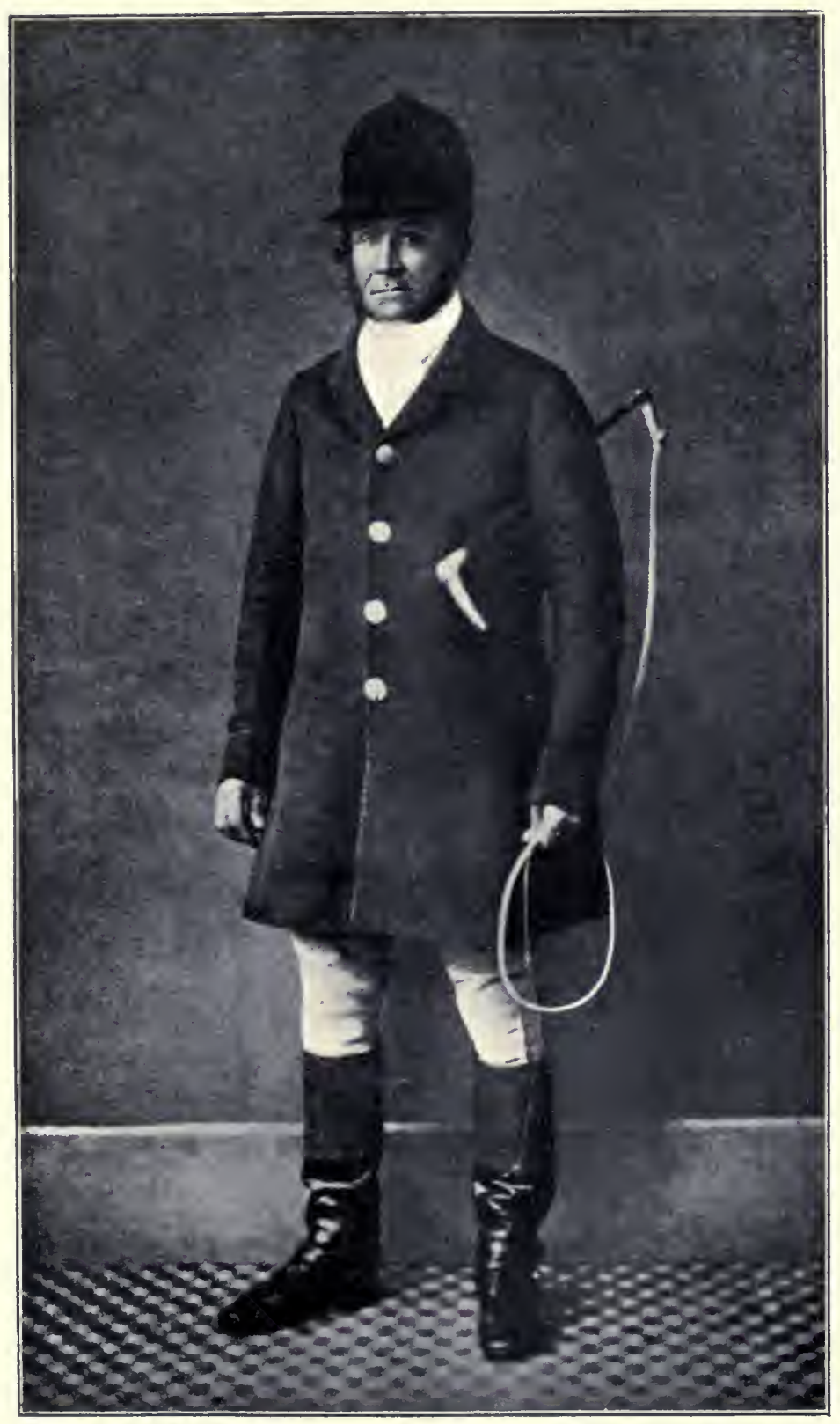

JOHN WALKER, FIFE HOUNDS.

I 829 - 1848 . 

You now know what has passed between Sir Watkin and me, and can do what you consider best for yourself."

As Payne was going to leave at the end of the season I had to look out for another huntsman. I went down to Cirencester to see Fred Turpin, and also went to see Doudswell, Lord Macclesfield's huntsman. I settled to keep Richard Roake as kennel huntsman; engaged Ned Edwards, from Lord Fitzhardinge's, as first, and Tom Firr as second whip; Morris, my second horseman, and George Watson, Dick's second horseman; Frank Mapperson, kennelman; Will Ekins, his assistant.

Charles Payne's father was the regimental Sergeant-Major of the 9th Lancers, and Charles Payne was born in the regiment. His first service was with Colonel Morland, who commanded the regiment, and he went from him to Mr. Errington. I joined the 9th Lancers in 1836 , and one of Charles Payne's brothers was then a corporal in Captain Fullerton's troop, and went to India with the regiment in 1842 . In 1827 there was a vacancy for the adjutancy of the regiment, and Sergeant-Major Payne expected to get the appointment. For some reason he was passed over, and the commission was given to Sergeant-Major Cooke. On hearing of this, Sergeant-Major Payne went home, broke his sword in two, and placed it behind the fire, saying, "My soldiering days are over," and some time after he got his discharge. Charles Payne told me 
this himself, in I864, one afternoon while we were walking out the hounds at Brixworth.

"Pitsford, 6th March, 1865.

"I agree to continue to hunt the Pytchley country five days a week for the sum of $£ 3,300$, or four days a week for $£ 3, \infty 00$. In either case I propose to hunt one pack myself two days a week. "With regard to the hounds which I have added to the pack, the committee to have the option of purchasing them; or I give up the pack in the same state as to numbers and efficiency as I received them in May, 1864. That I be allowed the sum of $£ 40$ to expend in some alterations in the kennels and stables.

"I enclose a statement of the cost of hounds added by me, and also a memorandum of the state of Pytchley Hounds last spring.

$$
\text { "J. Anstruther Thomson." }
$$

\section{State of Pytchley Hounds.}

$$
\text { June, } 1864 \text {. }
$$

Old Hounds, sound . $\quad \cdot \quad \cdot \quad \cdot \quad \cdot 40 \frac{1}{2}$

" blemished Couples.

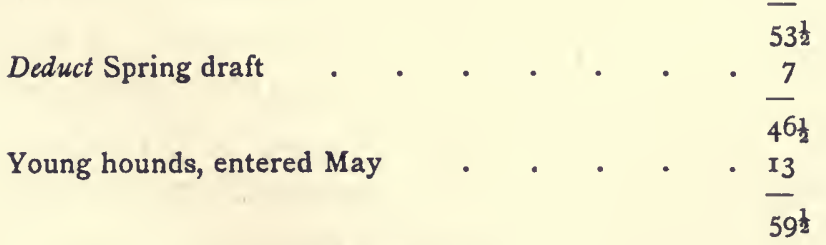

March, 1865. 
"George Hotel,

"I 5 th April, r865.

"Pytchley Hunt.

"My Dear Thomson,-

"At a general meeting held here to-day your proposal to hunt the country five days a week during the ensuing season at $£ 3,300$ was accepted. The committee have also been authorised to purchase hounds from you to the extent of $£ \mathrm{I} O 9$ and that $£ 40$ be allowed you to expend in repairs.

"The following resolution was then carried: 'That Mr. Thomson engage to keep up the complement of the pack to sixty couple of efficient old and fifteen couple of efficient young hounds; and that when he gives up the country he leave a corresponding number of hounds as the property of the country, and that the committee shall have the option of purchasing any surplus hounds which may then be in the kennel at the usual draft price; that $\mathrm{Mr}$. Villiers, Mr. Cust and the chairman (Earl Spencer) communicate this resolution to Mr. Thomson, and carry out any modifications that may be necessary.'

"This concluding paragraph signifies that should you be unwilling to agree to the last proposal, Spencer, Villiers and Cust have full powers to treat with you on behalf of the committee.

$$
\begin{gathered}
\text { "Yours ever, } \\
\text { "G. J. Whyte-Melvilie." }
\end{gathered}
$$

On I 7 th May, 1865 , Payne was presented with a testimonial on leaving. Fred Villiers made the presentation at the George Hotel.

VOL. I. 
Went to Charleton on Ioth June.

Commenced cub-hunting, second season, Nobottle Wood, 8th August, I 865 .

At Brigstock one morning when going out cubhunting Edwards and Tom were not to be found, so I went out with Dick and Morris. The two defaulters had been at a ball all night. I had received a doubtful character of Edwards, and told him he would be discharged without warning for his first offence. He was an ill-conditioned chap, so I started him. I then got George Orbell, but he was no use. I then engaged Humphrey Pearce, but he was no good either, but I kept him till the end of the season.

$\mathrm{My}$ mother and sisters were staying with me at Pitsford, when we heard that my brother had died at Calcutta. In the burial ground at Kilconquhar, in Fife, this tablet is erected by his widow to his memory :-

\section{WILLIAM ADAM ANSTRUTHER THOMSON,}

Lieut.-Col., gth Bengal Cavalry,

who died in Calcutta, 3rd August, 1865 , aged 42 years. He served throughout the Scinde campaign on the personal staff of Sir Chas. Napier; after which he was two years Adjutant of $1^{\text {th }}$ Irregular Cavalry; Commandant of the GovernorGeneral's Bodyguard for eleven years under Lord Dalhousie and Lord Canning; and Political Agent at Moorshedabad, which appointment he held at the time of his death.

"A character so noble, simple and true needs no description, but was appreciated by all who knew him; and its memory is fondly cherished by the wife and children he so tenderly loved."

My brother, William Adam Anstruther Thomson, was a subaltern in the Bengal Cavalry, and on Sir 
Charles Napier's staff during the Scinde War. He was present at the battle of Meanee in 1842 , and there lost a seal, a greenish-grey stone with the Thomson crest on it, and the motto "Honesty is good policy". The seal was afterwards found on the battleground by a private soldier. It was covered with clay. He gave it to a half-caste woman. She came to England on board the Himalaya as ayah in charge of some children in the same ship with General Taylor of Ogwell's children. She gave the seal to their nurse Harriet, who afterwards gave it to Miss Robertson, a friend of the Taylors, and told her how she got possession of it. Many years later Mr. Gathorne Hardy, then a schoolboy, was taking the impression of various seals with Miss Robertson and asked whose crest it was. She did not know, but sent it to Strongitharm, the seal engraver, who said that it belonged to a Scotch family, Anstruther Thomson. Miss Robertson gave it to my niece, Clem Campbell, and she brought it to Charleton in September, 1899. My brother's widow was at Charleton at the time. She said Willie told her that he had lost it at Meanee. She thought it was given to him by his uncle, Sir Charles Adam, who was a Lord of the Admiralty, when he was staying with him at the Admiralty before he sailed to India. It was thirty-seven years from the time it was lost at Meanee till Miss Robertson discovered that it belonged to the family of Colonel W. Anstruther Thomson.

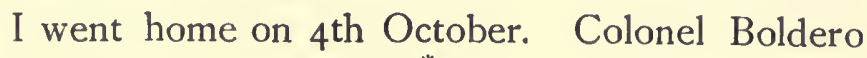
$22 *$ 
made an inspection of F. L. H. ; it took place on the 7 th at Cupar. Returned to Pitsford on the Ioth.

Whitehall was taken ill and died, and was buried at Brixworth on I $3^{\text {th }}$ October. I then put John Pye on to be stud groom.

November, 1865.-First Wednesday, Crick. I had picked all the best horses, and put Dick on to "Fresco," a capital little chestnut horse, which I bought from Dick Painter. Found a fox in Crick gorse, and ran down to Hillmorton. "Fresco" would not jump over a stick; he refused everything. I gave Dick my mare "Valeria" and took "Fresco" myself, but he was quite as bad with me; would not jump, and scrambled through everything. Next time he came out Tom Firr rode him. Galloping alongside of me he called out, "I could win the Liverpool Steeplechase on this horse, sir". Afte that no one else ever rode him, and he carried Tom all the time I had the hounds, and he rode him in the Waterloo run.

The cattle plague broke out in 1865-66, and there was a great panic among the farmers.

\section{" Drayton Lodge, Daventry, "26th December, I865.}

"Captain Thomson,"SIR,-

"By the papers, you meet at Badby Toll Gate on Saturday, and I suppose you intend to try the coverts on my farm, Staverton Wood, etc. I am sorry I cannot agree to the hounds going over my land, as I have an opinion that there is great danger 



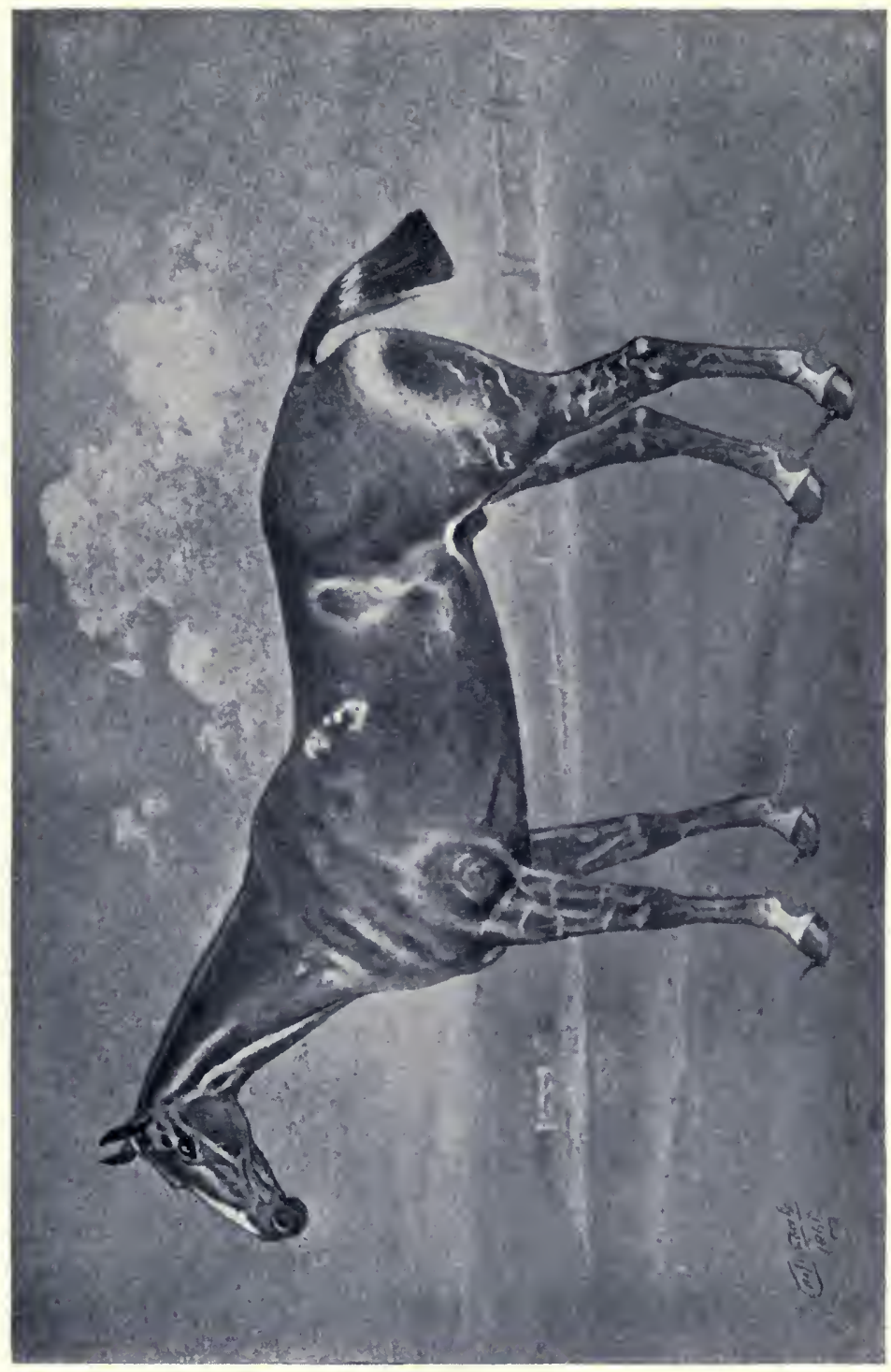

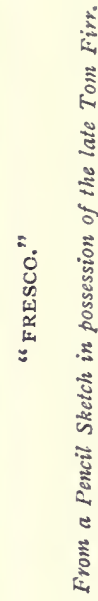


to cattle in hunting, it being a means of bringing the cattle plague. I have 103 bullocks on my farm, almost the whole in the fields, and I dare not put them in yards, as when one gets the plague there they all die, if they are together. I shall consider it a great favour if you would drop a line to say I need not fear. Hoping you will excuse me troubling you,

"From your obedient servant,

"George Emery."

"PITSFORd,

"Thursday, 28th December, 1865.

"Dear Sir,-

"In consequence of your letter having been directed to Brixworth, I did not receive it till after I had left home yesterday morning, and I did not return till too late for the post.

"I should be very sorry to be indirectly the means of doing any damage to your stock or of putting you to any inconvenience. I shall, therefore, for the present, avoid crossing your land as far as I possibly can, and I will not draw the coverts at Staverton to-morrow.

"Although I trust and believe that your fears are groundless as to hounds being the means of conveying the cattle plague, I have acceded to your request in deference to your wishes, and shall be much obliged if you will consider this letter as private.

"Believe me,

"Yours truly,

"J. Anstruther Thomson." 
"DEAR Sir, -

" 5 th January, 1866.

"I wrote to you on the 28th saying that I would not draw the coverts at Staverton in deference to your wishes. Since that time I have learned that there are no cases of cattle plague in your neighbourhood. I conceive that the only possible risk can be from cattle straying from field to field, and that may easily be obviated by attention in closing the gates. That hounds individually can be the means of conveying the cattle plague, I consider to be extremely improbable; no case of it has ever yet been heard of, and I may call to your notice the opinion of Mr. Mavor, V.S., which lately appeared in the newspapers. I have, therefore, considered it right to let you know that unless anything should happen to cause me to alter my opinion, I shall draw the coverts at Staverton as usual the next time that the hounds are in that district. I need hardly add that I will do all in my power to avoid putting you to any inconvenience, and that I have given strict orders to the servants to be very careful in closing the gates after them.

$$
\begin{aligned}
& \text { "Yours, etc., } \\
& \text { "J. Anstruther Thomson." }
\end{aligned}
$$

All the gates were doubled all over the country, and the slaughtered carcases were hung up in the fields before removal. A meeting of farmers was held in Northampton and a requisition sent to me to stop hunting, with three pages of signatures. Next day a requisition was sent to me with three 
times the number of signatures, desiring me to go on hunting.

"The Cattle Plague and the Pytchley Hunt.A meeting of farmers and other gentlemen residing within the district of the Pytchley Hunt was held at the George Hotel, on Saturday afternoon, to consider the question of fox-hunting in connection with the cattle plague. J. Topham, Esq., presided, and there was a very large attendance of persons interested in the question. On the motion of $\mathrm{Mr}$. Oldacre, seconded by Mr. Bennett, of Husbands Bosworth, it was unanimously resolved that a requisition should be sent to Captain Anstruther Thomson requesting him to continue fox-hunting until the end of the season, avoiding places where the cattle plague existed. It was also recommended that particular attention should be paid to shutting the gates of fields, so as to prevent cattle from straying. There was no dissentient voice in the meeting; immediately after which a large number of names were affixed to petitions."

The following morning at the meet, at Yelvertoft, I informed the assembled field of what had taken place, and requested them to give strict orders as to shutting gates. 
CHAPTER XX.

THE WATERLOO RUN.

I866, Friday, 2nd February.-Met at Arthingworth. I rode "Valeria" and "Rainbow"; Dick Roake, "Usurper"; Tom Firr, "Fresco"; Charlie (my son), "Amulet". I was staying at Sir Charles Isham's, at Lamport, and hounds called for me as they passed. A very wet morning, but cleared at eleven o'clock; very mild and still; not a very good scent in cover; wind, south-west. Found in Waterloo at five minutes past two by my watch (twenty minutes fast). The fox lay so still, I drew all round the cover, and back to the top before he moved. He lay among a heap of dead sticks; "Graceful" found him. Morris ${ }^{1}$ holloaed him away towards the tunnel. I was at the other end of the cover, and before I got to the hounds they had checked near the road. I took them along the road nearly to the white gate, where they got the line towards Arthingworth. They were ridden off the line in the first field, but swung round through the fence on to it again, over the brook and spinney at

2 Richard Morris, my second horseman, a capital man with hounds, many years with the Warwickshire, and with me in Bicester, Pytchley and Atherstone countries. 


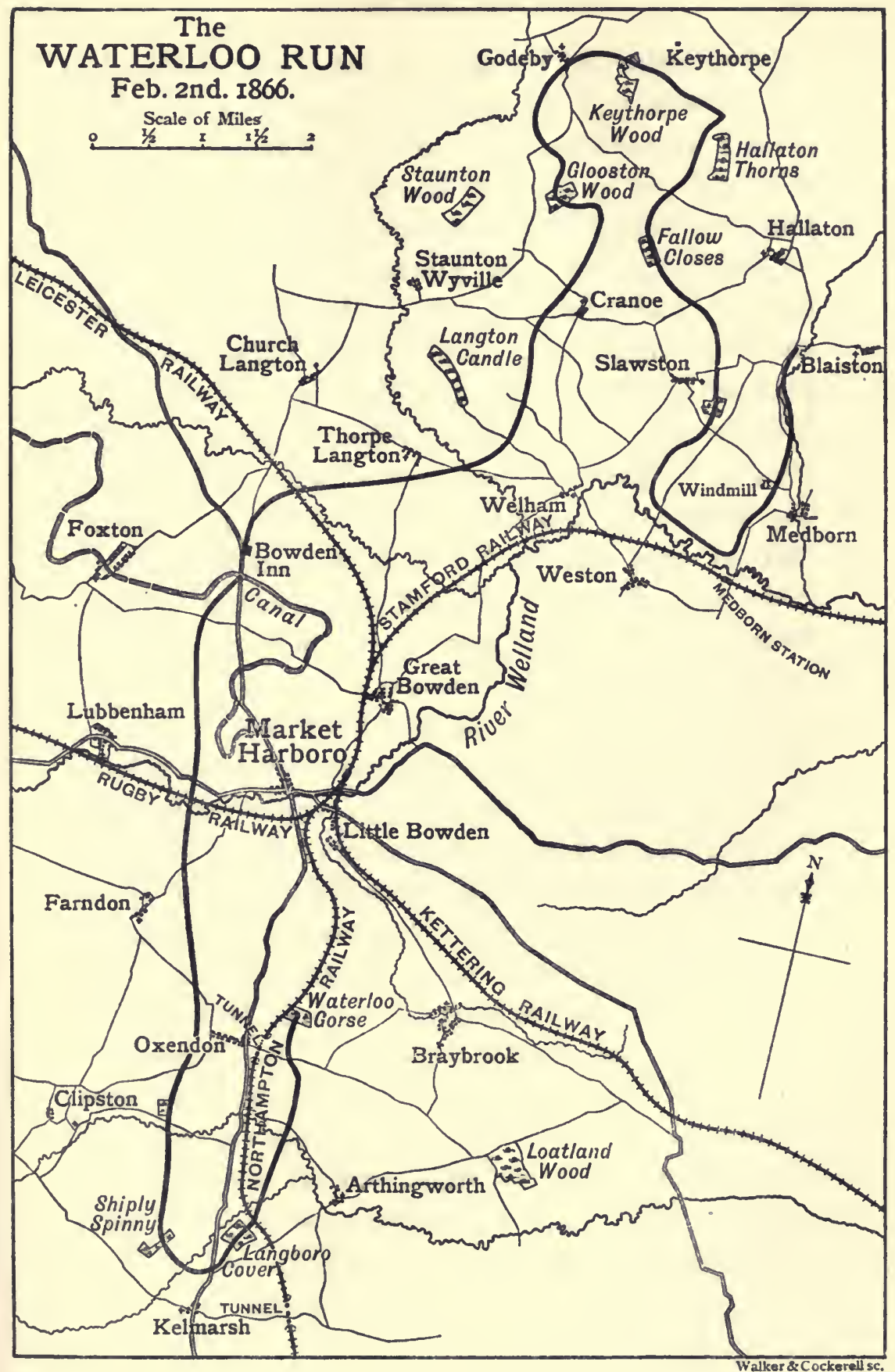


Arthingworth, and crossed the rail. The field was full of sheep, and the shepherd told me the fox had gone into Langborough. I carried them on, and just as I got to the gate he was holloaed away on the other side. I cut down the middle ride and got on the line, crossed the Harborough road, and we ran fast on to Shipley Spinney. Hounds just crossed and went right up the hill towards Clipstone, and then it began in earnest. Dick went round the Tallyho end of the spinney (Tallyho covert lies to the west of Shipley Spinney), and viewed another fox, and blew his horn, which distracted some of the field and put them out of it. Two fields further on there was a stiff stile and footboard, which lots of fellows tumbled over. I had a shy at the bullfinch up hill, high and strong, and it turned "Valeria" over. I lost a spur, which I put in my pocket, picked up the pieces and set sail, but I lost half a field, which I could not regain. Two fields on another stile, and lots of grief; Robertson ${ }^{1}$ and another down, blocked the way. The field then divided into two lots, the right-hand lot well with the hounds-Custance, Tom, Charlie White, Fraser, Topham, and perhaps twenty more; the left-hand lot-myself, Mills, De la Cour, Boyd, etc.-about a field and a half behind the hounds. Hounds ran on without a pause past the spinney between Oxendon and Clipstone, leaving Oxendon village to the right, into the Farndon and Oxendon road. I came into the road opposite Mr. Kirkman's house. They checked here, and I lifted

${ }^{1}$ Brother of Captain Robertson, Royal Dragoons. 



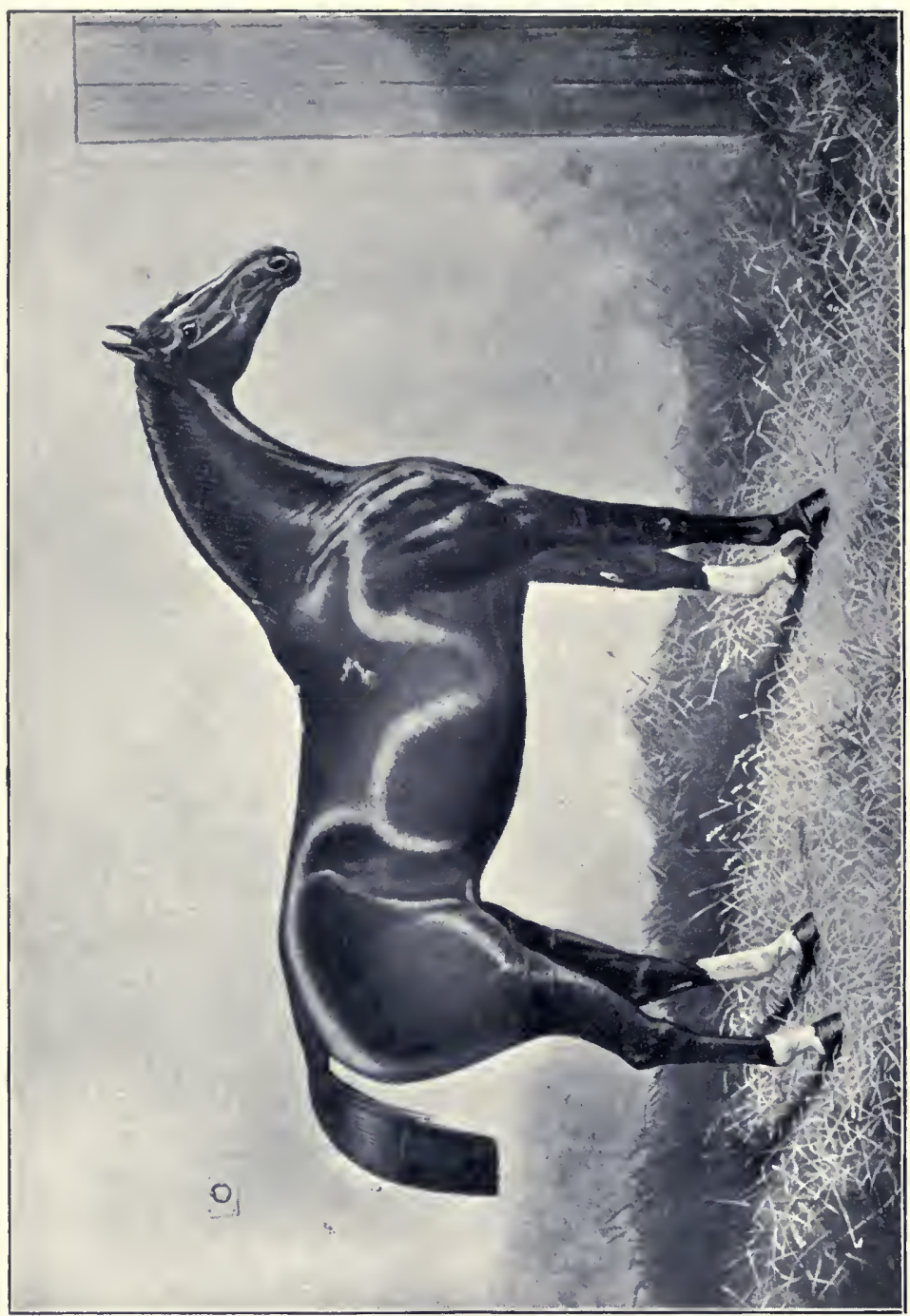

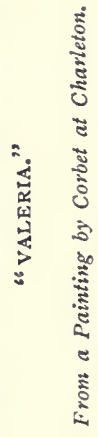


them on to a holloa one field off, having to jump a nasty double, with a rail towards me to get at it. "Governess" first spoke to the line, and off we went again, crossed the bottom from Farndon, which Vivian jumped first and fell; I scrambled in and out. Nethercote, White, Fraser and Topham were first at the next fence. Hounds then began to go down the hill towards Lubbenham, one field to the right of the Farndon and Harborough road. I got into the road, and here Dick and Charlie (my boy) joined us. Hounds crossed the road into the big field, at the Harborough corner of which is the Welland river. Charlie had a shy at the rails and tumbled over them. I went further up the field for a broken rail. Dick and I both lay to the left for Lubbenham covert, thinking that was his point, but he crossed the river and rail at the Harborough end. We lifted the railway gate off its hinges, and crossed near the covert-Topham, Mills, Mayou, Charlie, etc. We caught the hounds at the Harborough and Lubbenham road. They then turned their heads towards Bowden Inn, and began to run hard. Grief began to be visible at the next fence, a nasty place up hill; Birch Reynardson had his horse in the ditch, and was exclaiming, "Oh, dear! oh, dear!" Two fields further on my mare began to trot (she had a good dressing with the first fox, having run an hour up and down the rides in Loatland Wood). I heard Dick whistle behind me, and say, "Take my horse, sir; he has ten minutes left". I changed with him, and told him to get "Rainbow" from 
Morris as soon as he could. "Usurper," his horse, was fresh enough, for he rushed at the first fence (a drop), over-jumped himself, and gave me a regular burster, and knocked five minutes of the ten out of himself. No harm done; scrambled on and caught the hounds at the railway bridge at Bowden Inn. The fox had run the road. "Relish" hit the line through the hedge on the right, and Tom held the rest up to her. The field had cut off the tail hounds, and got "Flasher" and "Graceful" in the middle of them, and were playing at football with them, for which I blessed them. They ran round the back of Bowden Inn, paused for a minute at a plough, and crossed the rail at the first crossing right of the Langton road. "Flasher" first over the rail, and then over the brook, and on as if for Langton Caudle. Frank Langham went at the brook, and his horse jumped in. Tom Firr, seeing the bottom was good, jumped in and out. Custance jumped it well, just as Tom got out. Mills and I jumped it more to the right, in a watering-place, and got over well; only two others, Langham and Tom, over before us. It caused lots of grief, and many took to the road at Bowden Inn. White and Fraser's horses stand there, and they both got fresh horses. The fox was headed on the top of the next hill and turned along the valley. Here Charlie White came up on a fresh grey horse, and kindly offered to let me have it. We now began to be a mutual assistance society, and help each other, and pulled down rails and made gaps. Crossed the road between Thorpe 
Langton and Great Bowden; hounds still carried on steadily. I just saw Langton Caudle, which we passed on our left, and thought it would be the end of the journey, and that I could just hug up to it. Crossed the Thorpe Langton and Welham road, got through the brook at a ford. Going up a hill, "Usurper" dropped into a trot, and Mr. Hay lent me his horse, a brown thoroughbred. The first gate I came to half closed and touched his side; he plunged and pitched me clean over his head. We here came to a ploughed field and a wheat-field. The field remained on the grass on the top of the hill. I went with the hounds, and had to jump a ditch up hill out of the plough. The horse did not land his hind-legs, and was not strong enough to get up, so I jumped off. At the bottom of the hill a "Pat" holloaed us on: "Just gone when I holloaed". Off again over the grass, turned to the left, passed a brick kiln, crossed the road between Staunton Wyville and Cranoe, and up hill to a spinney. Hay's horse could gallop well, so I got on to the other side, stood still for a minute, and saw hounds come out, " Royston" hunting it single-handed through the sheep; and then "Monarch" spoke on the other side of the hedge. The rest came bundling on, and away we went, "Cherry" Angel ${ }^{1}$ here in company. Crossed a lane near Glooston village, and carried on well through several fields full of sheep. "Hurrah for the Duke of Beaufort!" said I-" Ferryman," 2 guiding the

${ }^{1} \mathrm{Mr}$. Angel of Lubbenham. "Cherry," contraction of Cherubim, his cognomen at Eton.

a "Ferryman," by Duke of Beaufort's "Finder". 
scent, leading to Glooston Wood. "I always told you so," says Captain Clerk (Tailby had been in it the day before). Through the wood like bells, and away on the other side towards Skeffington. Allan Young holloaed them away. On coming out of the wood I had a shoe off, and Walter de Winton changed horses with me. There is a nasty deep bottom at the end of the field, where Custance got his horse fast ; my horse, or rather Walter de Winton's, refused it, and Edghill ${ }^{1}$ scrambled in. Just then I heard Dick whistle, and found him on the other side on "Rainbow". I jumped off, got over the rails, and set sail all right again. Some men rabbiting had turned the fox half a field to the left, and they ran clean away from us again. John Chaplin and another were before me, but kept too far to the left. I got along the road to Godeby with Colonel: Mayou, and caught them at the corner of the road, and then went on with them alone to Keythorpe Wood. Here they checked a moment in the, wood; or at least did not speak. I got on to the middle ride, and saw "Singer," "Streamer" and "Ferryman" cross, but not on the line; however, they hit it off again, and went away towards Ramshead. I got the rest after them, and had eleven couple on- "Fanny" the last hound out. Dick and Tom both there. Three fields further on the fox tried the earth, where Tailby had run to ground on the previous Tuesday, and dug out. I looked at my watch; one hour and fifty minutes, and, I think, about eighteen miles, and hounds had only

${ }^{1}$ Edghill, I7th Lancers. Killed in the Zulu War. 


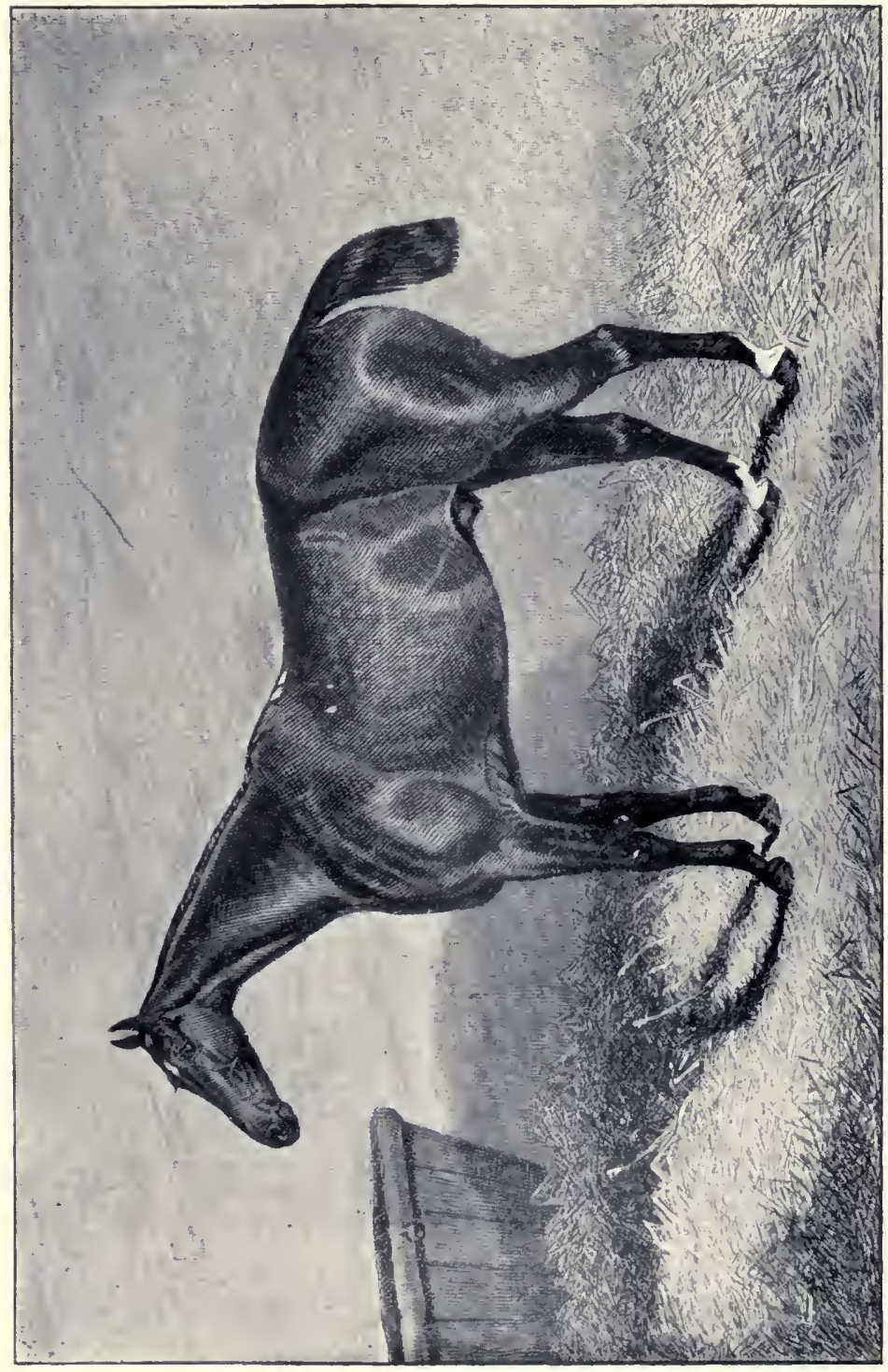

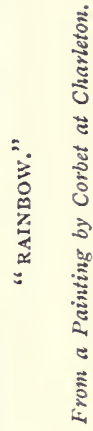



once been off the line, when I lifted them at Little Oxendon. Here there was something like two lines, the body of the hounds going down the field towards Ramshead; a few others had a scent on the righthand side of the hedge. Coventry ${ }^{1}$ joined us somewhere here, with a pair of trousers on. I heard Tom, a field behind me, holloa, "Yonder he goes!" and, at the same time, Colonel Fraser told me one and a half couple of hounds were two fields on to the right. I thought the fox had gone through Hallaton Thorns ; there is a deep bottom and very steep hill here. I lifted the hounds (hoping to catch the leading ones there) to the far side of Hallaton Thorns. When I got half-way up the hill, two gentlemen on foot, who were rabbiting, showed me where the leading hounds were; they had not come into Hallaton, but were pointing for Fallow Closes, along and outside the fence, in at the gate, and then away along the bottom. I only got thirteen couple away from here, "Merryman," "Streamer," "Relish," "Ransom," "Dragon" and "Singer" generally leading, and all working well. "Frantic," though she had not been out for weeks, was there. We passed Mr. Studd's house, and they ran away from us again down to Slawston covert. They just came out of the cover as we got there. The field was full of sheep, and they got the line at the cross roads. While we were on the road some men on the hill viewed the fox

${ }^{1} \mathrm{Mr}$. Coventry (B) was driving into Harborough. He put up his trap, borrowed a horse from Mr. Angell, and joined in the pursuit. 
going along the hollow behind us, only one field off. We cut along the road, and got on the line directly, ran hard down the meadows to the Welland, near the angle of the river at Welham; turned to the left along the bank of the river, as far as the road which goes to Medbourne station, there turned to the left up to the windmill, and got on to ploughed land. Here Captain Clerk turned up. The fox had been coursed by a sheep-dog, and repeatedly turned. This caused a long check (perhaps twenty minutes). A man told me he had gone slantways across a large wheat-field (which was wrong), and after holding the hounds all round it, I got the line straight on again in the direction we had formerly been going, but with a failing scent. The hounds crossed the line without acknowledging it ; "Relish" stopped back alone, and made a drive down the furrow without speaking to it. I put the rest on to her, and in the next field they began to hunt it again, but they could not go the same pace as before. They crossed the road between Medbourne and Hallaton, and ran up the side of the brook to the road which goes to Blaston, "Graceful" being the last hound to hit off the line; she had also been the first one to speak to it in the morning. It was then getting dark, and I was afraid we might lose the hounds, so I stopped them at $5 \cdot 30$, having run three hours and forty-five minutes. There was a holloa about two fields on at the time. Mr. Piercy, the clergyman at Slawston, had come out on foot when he heard the hounds. He took us to his house and refreshed us, gave the horses gruel, 
and treated us hospitably, and most kindly offered me a hack if I wished to leave my horse, but he was not tired, and carried me home quite cheerfully. $\mathrm{He}$ carried me more than two hours, and never made a mistake-a pretty good trial for a five-year-old. I had gone on for an hour and forty-five minutes without a whipper-in, or having the hounds turned to me once. Captain Clerk, who was the only man who went through on one horse, helped me through Market Harborough; all the rest of the way we jogged side by side, and the hounds trotted along with their sterns up. It was a fine, mild, quiet night. I stopped every three or four miles, and called them ; they all came round me, wagging their tails, and trotted on again. We got to the kennels, eighteen or nineteen miles, about ten o'clock.

At Lamport I met all the party starting for the Harborough ball. My wife returned, and waited while I went to Brixworth with the hounds, got a hack and galloped back to Lamport. I met Dick with "Usurper," just as I was coming out of Brixworth. I sat down to dinner at ten minutes to eleven o'clock, got to the Harborough ball at I2.30, and remained two hours. I was very little tired, and was at Ashby St. Ledgers by twelve o'clock the next day.

After I changed horses with Dick ${ }^{1}$ at Glooston, he came on with Mr. Hay's horse to the top of Hallaton Thorns, but finding he could not go the

${ }^{1} \mathrm{R}$. Roake had been second horseman with Mr. Tailby, and was thoroughly well acquainted with the country.

VOL. I. 
pace to be of any assistance, he came quietly on to Fallow Closes, picked up "Tyrant" (who was short of work, having a toe-nail off) and "Bluecap," and went to Mr. Hay's, at Great Bowden. He there got his own horse, who had eaten a feed of corn, went into Harborough to get a shoe put on, and jogged on home. Charlie went as far as Langton, overtook Morris at Bowden Inn, and went home with him. Tom's horse, "Fresco," carried him capitally up to Keythorpe, and there he stopped trying to get up to me when he viewed the fox. He came on as far as Slawston, and then went on to Bowden Inn, where his horse remained all night. John Pye, my groom, came on the carriage to Harborough when we went to the ball, and brought him home next morning. Tom Firr came home on the box of the carriage after the ball. Of the hounds left out, "Bowman," "Fanny," "Governess" and "Glory" came home next day; "Monarch" came in on Monday. I never could see the fox or get any advantage on him, and I don't think I lost a chance. At Keythorpe we may have changed, for Tom saw a fox besides that which the hounds were on. Tailby had been in Glooston Wood the day before. There was no check or perceptible change of scent.

This was the best run I ever saw, and over the finest country and longest distances, straight. There was one ploughed field between Waterloo and Kelmarsh; the second was next the railway behind Bowden Inn. There was a wheat-field and a 
ploughed field together near Cranoe, and I don't think the hounds were ever off grass, with these exceptions, up to the earth at Keythorpe, one hour and fifty minutes. The hounds worked well, chasing and carrying a good head up to Bowden Inn, hunting steadily through sheep and all difficulties; they were very fit to go, and not an ounce too much flesh. They did a wonderful day's work, having run their first fox an hour and five minutes before they began with this one.

\begin{tabular}{|c|c|c|}
\hline \multicolumn{2}{|c|}{ Pytchley Hounds. } & \multirow{2}{*}{$\begin{array}{l}\text { Young Hounds. } \\
\text { Dragon }\end{array}$} \\
\hline Regent & Singer & \\
\hline Monarch & Streamer & Flasher \\
\hline Falstaff & Statesman & Folly \\
\hline Pilgrim & Tasty & Frantic \\
\hline Governess & Tyrant & Glory \\
\hline Gambler & Dashwood & Gossamer \\
\hline Plunder & Driver & Gaiety \\
\hline Royston & Druid & \\
\hline \multicolumn{2}{|c|}{ Ferryman-Beaufort. } & $\left.\begin{array}{l}\text { Bluecap } \\
\text { Graceful }\end{array}\right\}$ Meynell. \\
\hline $\left.\begin{array}{l}\text { Merryman } \\
\text { Ransom }\end{array}\right\}$ & Fitzwilliam. & $\left.\begin{array}{l}\text { Romeo } \\
\text { Promise }\end{array}\right\}$ Warwickshire. \\
\hline $\left.\begin{array}{l}\text { Relish } \\
\text { Singer }\end{array}\right\} \mathrm{Bra}$ & imham. & Bowman-Lothian. \\
\hline
\end{tabular}

$\left.\begin{array}{l}\text { Fanny } \\ \text { Lancer }\end{array}\right\}$ Lord Henry Bentinck.

Some years after I met Sir Charles Mordaunt and Captain Gilbert Robertson, and they told me their experiences. Sir Charles Mordaunt said, "While I was fording the brook near Bowden Inn, Murietta rode at it and tumbled in and splashed me all over. I left my horse at Cochrane's (The Old Ship) at East Langton and he lent me a hack to ride home." Captain Gilbert Robertson said, 
"When my brother tumbled over the stile at Shipley, I jumped the hedge on his left. I forded the brook at Bowden Inn at the same place as Tom Firr, while Custance jumped it on his right. I got as far as Cranoe and stopped, feeling my horse's heart beat against my leg. I got some gruel and got home well to Bosworth Hall. My brother's horse was dead beat."

Tell me, old chap, if acquainted you've been, Of the doings they had t'other day :

How the hounds ran away and beat them all clean, Every man who took part in the fray.

Waterloo was the place where they put up their fox, And away they all scuttled like mad,

Till one and another had settled their crocks, Each man looking darnation sad.

Round Kelmarsh and Clipstone, where many got spilt ;

Lorks bless ye, to me 'tis a wonder

Over Oxendon fields there was none on 'em kilt

$O$ 'er the oxers which rattled like thunder.

Right on past Farndon and Bowden Inn,

With many a tile that was broken,

Until but a few of the best were left in,

Not one with much go could betoken.

When down to the brook below Langton they went,

I seed there was sport, for none feared it,

They rode like the deil-on being over was bent-

Harry Custance was all though as cleared it.

Then on towards Cranoe and Keythorpe like crows,

The pack skid away o'er the pastures-

How the folks follow'd arter, the Lord only knows-

Each and all meeting many disasters.

Past Hallaton Thorns, where some cove got a view,

"Yoiks for'ard," he shouts, "tally-ho,"

'Till the Captain came up, and his whistle he blew,

"Come, tell me then, where did he go?"

"He's gone for the Welland, dead beat," cried the man;

Like a genius the Captain besought him;

Evening came on, and then darkness began-

You bet, he'd like to have caught him.

TOM FIRR. 


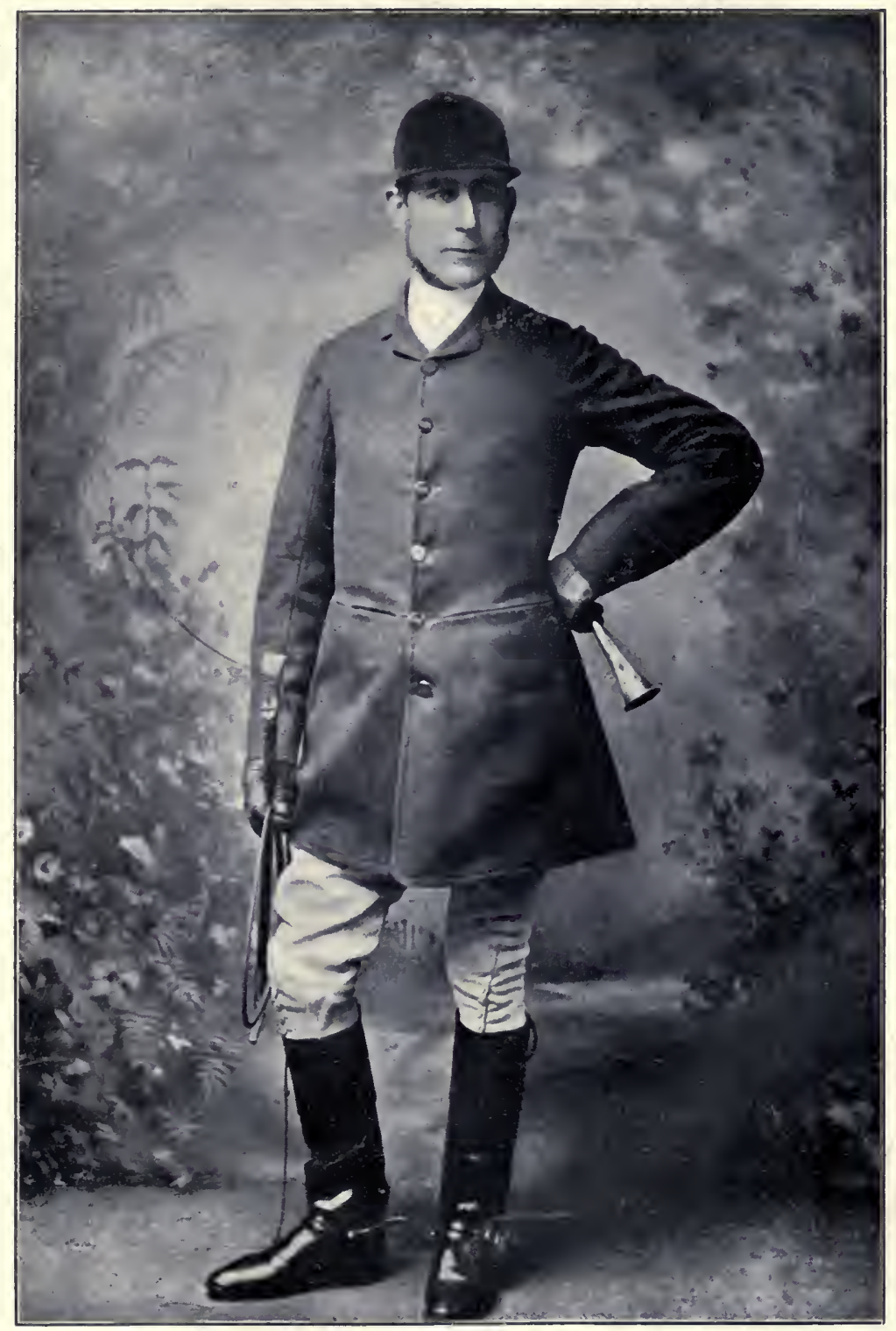

TOM FIRR (ABOUT I870). 

2nd February, 1866.

"Sir,-

"The accounts of the Waterloo Run have. been so many and so various that your readers must be puzzled to know the real state of the case, and as 'Bailey' is not quite correct, I venture to send you what I believe to be the leading facts in the day's sport.

"The hounds found their first fox in Loatland Wood, and ran in and out of covert for one hour and five minutes, and ran hard to ground at Arthingworth. They found again in Waterloo Gorse, at a quarter to two o'clock. The time from Waterloo to the earths at Keythorpe was one hour and fifty minutes. The total time was three hours and fortyfive minutes; but we had a long check, twenty or twenty-five minutes, at the windmill at Medbourne, and hunted on slowly afterwards. I take the distance to be-from Waterloo to Kelmarsh, three miles; Kelmarsh to Keythorpe, eighteen, as we ran it-twenty-one miles in one hour and fifty minutes. There were only four ploughed fields in that distance. The hounds were only off the line once, between Kelmarsh and Keythorpe, when I lifted them one field to a holloa at Little Oxendon. As to changing foxes, I don't think we changed at Shipley Spinney. We might have changed when I lifted the hounds at Little Oxendon; but I don't think we did, as it was quite in the same direction our fox was travelling. I think we changed at Keythorpe Wood, as another fox was viewed there 
besides the fox which we followed to Medbourne We may have changed anywhere in hedgerows, but I saw no perceptible change of scent, or anything to cause me to think so.

"Some of your correspondents have asked where I managed to get five horses during the run. They will see in 'Bailey' that. I was indebted to the kindness and sportsman-like feeling of my friends Mr. Hay and Mr. Walter de Winton, and I beg all of them to accept my most grateful thanks. Both Colonel Fraser and Colonel Whyte on getting fresh horses also most generously offered them to me. Captain Clerk was the only man who rode the same horse to the end of the run, and rode home with me to the kennels. I left two and a half couple of hounds out (not four and a half in the covert at Fallow Closes), but they all came home next day, except one, and he came home on Monday. The only men present when I stopped the hounds were Captain Clerk, Colonel Fraser, Colonel Whyte and Mr. John Chaplin.

"This I believe to be a correct statement of the leading facts. I can only add I never saw hounds carry on so far at the same pace, and so straight and over so fine a country.

$$
\begin{aligned}
& \text { "Yours truly, } \\
& \text { "J. A. T." }
\end{aligned}
$$

In spring of 1866 I wanted some more young hounds. I received a letter from Lord Doneraile, who was then Master of the Burton Hounds, but 
the hounds were still the property of Lord Henry Bentinck :-

\section{"Dear Thomson,-}

"I send with your man seventeen and a half couple, I think, of puppies-two and a half Goddard has hung; some small ones; seven couple we have marked with a clip on the throat. These are the lot we should have handed over to Augerstein."

They all arrived in the last stage of distemper. I wrote :-

"You were right when you said they were a bad lot. I never saw one like them-one died on the journey; three died last night; one is dying now; I expect two or three more will die before morning. What am I to do about paying for them? Surely you don't expect me to pay for the dead bodies and skins? I must really ask you and Goddard what you expect me to do about the settlement for the draft. Seven couple died in the first two days, and I believe they are now all dead except three and a half couple."

"HONRd. Sir,-

“Reepham Kennels,

" Ioth March, 1866.

"His Lordship gave me the letter that you wrote to him about the draft. I was sorry to hear that you had lost so many of them, i only have a part of the draft and Charles Hawtin the other part. It his a very Bad Job for me having such a few to 
send away. I hope, Sir, that you will pay for the I 8 couple; Charles expects his half of the money.

"Honrd. Sir, i Beg to remain your humble and obeident Servant,

$$
\text { "B. Goddard." }
$$

I replied :-

" 29 th April, 1866.

"I most decidedly object to pay you for the whole eighteen couple, and I do so on the principle that no huntsman has any right to send away draft hounds in the last stage of distemper when they could not possibly recover. If my man had come two days later, many of them would have been dead, and then you could not have sent them.

"You say it is a bad job for you having so few to send. It is a much worse job for me having to pay for what I have not got, as there are only two puppies fit to keep.

"However, I will send you a cheque for $£ 30$, and if you are not satisfied with that arrangement, I will refer it to any huntsman or Master of Hounds you like. Let me hear, and I will at once send you the cheque."

Lord Doneraile was afterwards Master of the Duhallow Hounds in Ireland, and his death was most melancholy and distressing. He died of hydrophobia from the bite of a tame fox which he used to take in his carriage. $\mathrm{He}$ and I were in the same tutor's house at Eton. 


\section{CHAPTER XXI.}

JOHAN ERASMUS BOEHM, AFTERWARDS SIR EDGAR BOEHM.

Bоенм was making an equestrian statuette of Lady Spencer. I happened to ride over to Althorp one afternoon, and Spencer took me to see the statuette and introduced me to Boehm. He had not then been very long in England, and did not talk English very well, but he knew it and wrote it very perfectly. He said that he wished to have an opportunity of studying fox-hounds, as he had an order from an American gentleman to make a group. I said, "Come and stay with me at Brigstock, and you can study them all day". I was staying by myself at "The Three Cocks". He came there and I lent him a pony to go out cub-hunting, and in the evenings he made little wax models of hounds. When he was going away he said, "Have you any objection to my making a model of you?" I said, "I shall be too proud". I then found that while out hunting he had made many sketches of me in different positions. $\mathrm{He}$ made the statuette without my ever sitting for it, and when he did the head, he had a bit of clay on the end of a stick, and walked about the room talking to me. His facility in modelling was most wonderful.

I believe Lord Spencer had mentioned him to 
the Queen, and he was desired to send two specimens of his work. Lady Clifden, one of the Queen's ladies, wrote asking if mine might be sent. As I knew that Boehm was away from home, I wrote to Mrs. Boehm.

\author{
"Gloster Hotel, West Cowes, \\ "ISLE OF WIGHT, .22nd January, 1869. \\ "My Dear Captain Thomson,- \\ "Pray forgive that only now I thank you
} for the kindness you had in writing to Mrs. Boehm about the statuette, which is now in my studio at Osborne and having been en face Her Majesty, during a long sitting she gave me to-day, formed the chief point of our conversation. From head to kneecap, from brow to toe, every detail was examined and bespoken; and you may be sure that I did not spare to speak of my kind mentor in the noble sport (though I do him little honour in that line) with all the enthusiasm I feel for you. You have no idea what use that statuette has already been to me. I soon expect your exemplar, which I wish I had had instead this one, which is a second, though good, cast only of the original bronze of yours, that I believe will in a few weeks be back again with proper colour and accoutrements. But now if you are ever so tired from ever so fine a run, you must hear my rambles across country from Deene to London, where I had only a few hours cheque (check), and on again at the rate of fifty miles an hour to Osborne. I have to thank you the preliminary introduction or proposal of an equestrian statuette, of the most charming of all 
hostesses-Lady Cardigan. There I did a bust of her, intended for reproduction on the monument, by the side of the late Earl, to be executed to both in her life-time. The bust having been approved of is to be done as a bust in marble, besides the monument and also the equestrian statuette on Sultan. I had scarcely finished when kind Lady Clifden's letter came, and the order soon after that I was to be off to Osborne. Yesterday the Queen shewed me the horses she wished to have done--one thoroughbred chestnut, full of character and some beauty, with the name of Andrew (instead Methusalem), with the Princess Louise on, who has a splendid seat and a beautiful figure. Another favourite cob which Her Majesty rides, with an attendant in Scotch costume, a nice peculiar shape, lean and sleek cob, and a charming head, also a good subject. And thirdly, the most important of all, the Queen herself, sitting and spinning with a favourite collie at her side. I cannot tell you how kind, how amiable she is, and with what interest she inquired about all my works, etc. She has the sweetest, purest expression and smile when she speaks, and is so natural and courteous. Oh, it is such a difference to the house of Austria, who might take many a good lesson of the behaviour necessary if they wish to endear themselves to their subjects. England for ever. I need not tell you how I shall try to deserve all my good lucksuch I may call it. If I lose one kind patron who leaves as a viceroy, I find one other in a queen. Please forgive all this egotistical account, but I know 
you take an interest; and I am so glad to have an opportunity to do the best I can in these new works, and I hope I may succeed, as my best will be but poor. I hope Mrs. Thomson and family are well, though the last accounts I heard were not so favourable of Mrs. Thomson's state of health. Please to give her my best compliments, and to remember me also to J. Pye. I hope you will find some day some nice cheap horse for me-I long for one.

"Ever sincerely and obligingly yours,

"J. Е. Военм."

Boehm made a beautiful statue of the Queen, life-size, sitting with a spinning-wheel and a collie dog lying by her side. He very often came down to Brixworth, and used to ride an old horse of mine called "Rocket," but he did not like my plain flapped saddles, so I got one with plenty of stuffing in front of the knees. He said, "The saddle was charming, and Rocket was charming". He jumped a small brook, a branch hit him on the face, and knocked his hat off into the brook. He picked it up and put it on: "Trickle, trickle, and I said to myself, here comes bluid, but it was water".

Boehm's father was the manager of the mint in Austria, and his principal occupation as a boy was drawing designs of the emperor for the dies for coins. He first went to Paris, but he did not like the French style of equestrian statues-they were too ideal, and he wanted something more real; so he came to England, and commenced with statuettes, 
but his great ambition was to get great works. His statues of horses were wonderfully true and life-like; and among his statues of men, Carlyle was one of the best. He was very industrious, and never lost a chance. If a horse tumbled down in the street, he would sketch it in his pocket-book. My eldest boy stayed with him some time in London, and he made a beautiful bust of him (while an Eton boy).

He was a most agreeable, charming companion, and the kindest and best of friends. He made me a present of my statuette, and afterwards his charge for them was 300 guineas. His studio was a constant source of pleasure to me when I was in London; and he allowed my daughter to go there when she liked to model or draw.

\section{"13 Summer Place, "Onslow Square, ist December.}

“Dear Colonel Thomson,-

"I heard a few days ago that the new series of bronze casts of your statuette, the Duke of Beaufort, etc. etc., will arrive here from Germany the end of this month, and as soon as I have it I shall send your bronze to Brixworth. I am very sorry for the long delay, but under five or six months I cannot get any order executed there, and as I cannot get it anywhere done like that, I must submit to it. I have just made arrangements with a jeweller, who is going to open a shop in the middle of St. James' Street, to publish my bronzes, and am working hard at making several sporting groups for stock, under 
others also 'The Death,' with nine or ten hounds, which has been begun so long ago, and will I hope be finished at last. I hope the speculation will not be a failure. I find that the thing would take, if it were more known, and therefore chose that way of publicity. I don't know whether I have written to you since I saw 'Highlander'. $\mathrm{He}$ is a wonderful horse, and ought to be kept in an academy as a study for artists; in some future time, perhaps, it may be thought a not quite inseparable branch of art to study animals too. I was astonished when I came back at the wonderful exactness of your outline of him. As pendants to my bulls I have made two groups of cart-stallions, which I should be very glad if you could see. If you have room anywhere, and don't think the large statue of the duke too bad, and like to accept it, I shall be glad, if you like to take it from my studio. I am only afraid the plaster won't stand the open air, but would do in the kennel, or some place like that. I hope Mrs. Thomson is better, and beg to be kindly remembered. I am so sorry I missed your two sons and Miss A. Thomson the day before yesterday, when they called here. Could you make me a sketch, when sometime at leisure, of a dead fox, how the huntsman holds him to shew the hounds. Excuse the liberty of asking you that trouble, and believe me,

"Yours sincerely, "J. Е. Военм.

"I hope John Pye's leg is well again." 
"The Avenue,

" 76 Fulham Road, S.W.,

" rgth November, 1872.

"My Dear Captain Thomson,-

"It reminded me quite of the delightful days when I began and ended my hunting career when the post this morning brought me a letter from you and Captain Percy Williams-the days of which I always shall think back with infinite delight, and shall never cease bragging of having been out with you or of getting a gate slammed on my shins by Percy Hotspur-the days when I ordered a pair of breeches by Hammond, in which moths hunt now instead I in them. Shall you never be any more within reach and have a 'Rocket' for me? I shall of course be very glad if Sir Windham Anstruther will call and wishes a copy of your bronze, the only really popular one I ever published. I was obliged lately to raise the price of it to thirty guineas in bronze, because they now charge me exactly double for everything in the German foundry, since the strike system has found its way there, and the late war increased the demand for superior workmen. I was told that out of seventy-four young men who had to join the army from the foundry at Lankhammer only twenty-nine returned after the unfortunate time was over! and I have to try now to get my bronzes done in England.

"I am full at work on John Bunyan-a ten feet figure is more amusing to do than small statuettes, and certainly not so trying to the eyes. 
"We have now left the house in Onslow Square, which Mr. Mackenzie of Seaforth has made into a Bijoux Museum, full of armour and trophies, etc. I hope Mas. Jack is well, and that Miss Kitty will find plenty of amusement in modelling, than which there is no more fascinating occupation. If I can do anything to aid I shall be most happy. I believe Mr. Steele is a very nice man and a clever sculptor, who I am sure would be useful; also a Mr. Hutchinson, a clever sculptor whom I know. Please give my compliments to Mrs. Thomson. (I hope everything will come off happily.) "Believe me,

"Yours most sincerely,

$$
\text { "J. Е. Военм." }
$$

His death was very sad and sudden. He was found dead in his studio when one of the royal princesses went there for her lesson in modelling.

"Pitsford, " 22nd March, 1866.

"My Dear Melville,-

"I beg to make the following offer. I am willing to hunt the Pytchley country four days a week. The subscription to be $£ 3,300$, as at present. I hunt the hounds myself. I have spoken to Dick, and he is willing to remain with me under this arrangement. "Ever yours truly,

$$
\text { “J. Anstruther Thomson. }
$$

"Pray let me have an answer 'Yes' or 'No' as soon as possible, and if there is any decided objection to this proposal, please withdraw my offer at once." 
"Dear Thomson,-

"Carlton Park, Rockingham, " 2 th March, 1866.

"I am very sorry to hear that there is a probability of your giving up the hounds. I am, as you know, badly situated for getting out with the Pytchley, but if things can be so arranged as to induce you to continue the mastership, I shall have much pleasure in giving you a subscription of $£_{50}$ a year. The only condition that I should like to attach to this offer is that the Forest Day should be changed from Tuesday to Monday. Tuesday is my magistrate's day at Harborough ; and if this change could not be effected, I could hardly hunt with the Pytchley at all without shirking my duties at the bench.

"My offer of a subscription is personal to yourself, and I will not pledge myself to your successor.

"Believe me,

"Yours very truly,

"Geoffrey Palmer.

"Pray give me a line, in answer, to Senior University Club, Suffolk Street, Pall Mall, London."

"At a meeting of subscribers to Pytchley Hounds, held at the George Hotel, Northampton,

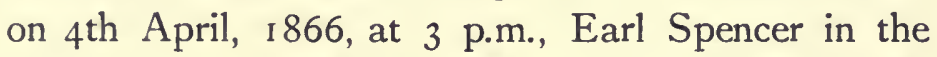
chair, it was agreed that Mr. Thomson's proposal to hunt the open country four days a week for $£_{3,300}$ during the open season with a huntsman and two whippers-in, and to make arrangements with $\mathrm{Mr}$. voL. I. 
Watson for managing the hunting in the woods during the open season, be accepted, provided the necessary funds be raised for the purpose, and that the terms of the arrangement between $\mathrm{Mr}$. Watson and Mr. Thomson be settled by a committee, to consist of Sir R. Knightley, Bart., Hon. F. Villiers, Hon. C. Cust, A. A. Young, Esq., Captain Clerk. A letter from the Earl of Cardigan on the subject of the above arrangement was considered and referred to Captain Thomson and Mr. Watson.

"It was agreed that when Mr. Thomson has made up the seventy-five couple required of him, according to the agreement of last year, the above committee should arrange the number of hounds to be kept up under the new arrangement and the manner in which the hounds to be deducted (if any) should be disposed of. It was agreed that Major W. Melville be requested to act as secretary.

"(Signed) Spencer."

"6th April, 1866.

"My Dear Mr. Thomson,-

"I have heard in an indirect way that your offer to the gentlemen of the county with regard to the Pytchley Hounds is either accepted or likely to be accepted, and that there is a proposal for $\mathrm{Mr}$. Watson to keep a pack of hounds to hunt the woodlands. I hope you will not enter into any arrangement with him with regard to the appropriation of hounds with Mr. Watson for the purpose, because I cannot allow hounds kept by him to draw 
or run through any of my coverts. I congratulate you on your remaining in the country.

"Believe me,

"Very faithfully yours,

"Cardigan."

"My Dear Lord,-

"Briastock, 8th April.

"I received your letter yesterday. I am told, but I have received no official notice, that my offer to hunt the Pytchley country four days a week has been accepted. The idea of Mr. Watson hunting the woodlands was not suggested by me, and was no part of my proposal. I am sorry that your lordship does not approve of the arrangement. I was asked if I would agree to it, and at once did so, as it makes little difference to me, and would promote sport by drawing the forest foxes into the open country.

"I beg to thank you for your good wishes, and for all the kindness which I have received from you.

"Believe me,

"Yours very truly,

"J. Anstruther Thomson."

"Wooton Hall, Northampton,

" I7th April, 1866.

"My Dear JACK,-

"I enclose a copy of resolutions come to at the meeting on the 4 th, as sent me by Spencer. You should have had them sooner, but I thought he would tell you all about it. I was not present, so I don't know what took place, but I fancy when 
they had got rid of their talk they were unanimous enough. As Knightley does not mean to hunt next season, and it cannot therefore affect him, he is likely enough to have seized the tempting opportunity of a growl gratis.

"It would take a lawyer's opinion to decide how we all stand now, but I think it is clear that we give you $£ 3,300$ for four days a week in the open. I have sent circulars according to orders, stimulating the subscribers to fresh exertions under the system which has already fallen through. As, however, I do not find in the answer the slightest tendency to rise, I shall not distress myself on this point.

"I go to Hooton either Monday or Tuesday, according to my wife's arrangements for a move to London, so fear I may miss you on the road. You ought to go on Tuesday at latest, for the mug is run for (I think) on Wednesday.

"I hunted with Arkwright yesterday. Such a sweet pack! I think you would have said there was very little more to be done to these bitches, who worked like the squarest-headed dog hounds I ever cursed, and so handsome. He expects to see you at Cowper's Oak on Thursday.

"Yours ever,

"G. W. M."

I 866. - There was an idea that the forest should be hunted by a separate pack of hounds, and George Watson of Rockingham was quite willing to do it, but Lord Cardigan was strongly opposed to it. 
"Wooton Hall, Northampton,

" 8th April, 1866.

"My Dear Jack,-

"I have a very strong letter from Cardigan, written yesterday on his way through Harborough. He says: 'Speaking of the woodlands, I am anxious to communicate to you that I am quite determined to do everything to prevent a woodland pack being kept. I shall not allow any one of my coverts to be drawn by the proposed hounds of $\mathrm{Mr}$. Watson, and shall consider all running through my woods or over my lands as a trespass, and act accordingly, according to law. [!] I am quite serious and quite determined on this point, and I hope you will let it be known before the necessary arrangements are made.' He goes on to say he has written to you and hopes we shall talk it over; and concludes: 'The Pytchley Hounds are the proper hounds to hunt the Pytchley country.'

"You can show this to Watson if you think it advisable. I will write to him the gist of it by to-day's post. I fear it will be a very difficult matter to get Cardigan's permission to hunt his woods now (at least with Watson's hounds), and I do not see how the latter can do without it. I had already written very strongly to our impracticable friend, apprising him any permission he granted would not be abused, and Spencer had also dispatched a touching epistle, but it seems without effect.

"Yours ever,

"G. W. Melville." 
"My Dear Clerk,- -

"Bulwich,

" Igth April, 1866.

"I have this morning received from Whyte Melville the minutes of the meeting of the 4 th April. As you are a member of the committee, I want a little advice from you. It is left to me to arrange with Mr. Watson about the hunting of the woods during the open season. It is impossible that I can do so if the landed proprietors object to it, so presume that arrangement must be given up. I am to hunt the open country four days a week during the open season. Is that to hold good if the arrangement with Watson is given up; and am I not to go to the woods at all, and if I do, on what days?

"As to the hounds, there are now in the kennel seventy-one couple of old hounds, of which I shall draft ten couple before Ist May, to bring them down to the proper complement of sixty couple of old hounds. There are about twelve couple of young ones, which I must make up to nineteen couple before Ist May. How many am I to keep in future? I should think fifty-two old and twelve young would be quite sufficient, and what is to be done with the surplus? It is time to be looking out for a customer.

"I am going down next week to stay with Naylor for Chester Races, so I shall not see you for some time, and it is better to have these points settled at once. We meet at Biggin Park next Monday, and 
Brigstock on Tuesday, and if there is no rain I think we shall do no more.

$$
\begin{aligned}
& \text { "Ever yours, } \\
& \text { "J. Anstr. Thomson. }
\end{aligned}
$$

"To Capt. Clerrk."

$$
\begin{gathered}
\text { "Spratton, } \\
\text { "2oth April, } 1866 .
\end{gathered}
$$

"My Dear Thomson,-

"I have yours of yesterday. Melville, I think, made a mistake when he sent you the proceedings of the meeting of the $4^{\text {th }}$; such proceedings, I apprehend, were caused by the failure of the wild Watson scheme. I quite understood from Lord Spencer, on Saturday last, that you were to hunt the entire country nine days a fortnight, as proposed some little time ago, and I am sure it is Spencer's impression that it is so settled. I believe S. is now in London, but I will go over to Althorpe to-day on the chance of finding him.

"It is in my opinion a great pity that so much trouble should be created about the Brigstock country. The open country, as it is called, cannot be alone hunted four days a week; blank days will be the result of an attempt to do so, and it would soon dwindle down to a two day a week country. 'Keeping a country together' is one of the first maxims in hunting, I have been told.

"With regard to the hounds, if you do hunt nine days a fortnight, the hounds, I suppose, will require being kept up to sixty couple; but as I hope.to see you at Boughton to-morrow I will have 
some talk with you on the subject, if you have time.

"I should advise you not specifying any particular days for hunting the Brigstock country, but have it left to your discretion to do the best you can. It would probably be the best for you and the hounds to do more there before Christmas than when the days are at the shortest, and then in February to send one lot of hounds to Brigstock kennel for a week. Spencer did that, and every one seemed satisfied, and it did the hounds good. The foresters are not gluttons at hunting in the winter, however much they may like it at this time of year.

"Pray excuse all this rigmarole,

"Believe me,

"Yours very truly,

“ M. Clerk.

"Spencer is the person we really have to look to for support. There is no use in a few cottagers getting together and thinking to settle matters."

Met at Biggen Park on 23rd April. Last day. On 26th went to stay with Naylor at Hooton for Chester Races; George Whyte-Melville and John Welby were there; saw "Stockwell," the biggest thoroughbred horse I ever saw.

On I6th June, I866, Lord Rosslyn died in London. He had been very ill for some time. $\mathrm{He}$ was buried at Roslin Chapel, and I went with Loughborough, John Balfour and John Whyte-Melville by the night train to Scotland. We went straight to 
Roslin to attend the funeral. He was a Lieut.-General in the army and Lieut.-Colonel of the Fife Light Horse. He commanded the 9 th Lancers when I joined in 1836 .

So many mistakes arose in the consequence of there being two roads between the kennels at Brixworth and the house at Pitsford that I decided to live at Brixworth. I got possession of the "Nelson" public house, and had to take over all the pewter pots and the beer pump with it! I also got Dr. Noble's house, which was next to it, and I joined the two together. The kitchen was in Noble's house, and I made a "buttery-hatch" in the wall to put the dinner through into the dining-room.

I866. - The first hunt was at Althorpe on the I $3^{\text {th }}$ August. Dick Roake, kennel huntsman ; Tom Firr, second whip; and Will Goodall came from George Fitzwilliam.

3oth November, I 866. - The meet was at Duston. About eight o'clock in the morning Dick rushed into my house in his shirt sleeves and said, "What shall we do, sir? George has fed the wrong lot of hounds." "Why the devil didn't you feed them yourself? What have you got that are not fed?" "Seven couple of cripples or short of work." "Take all the lightest feeders, give them all a dose of salt and water and send them out to walk." About ten o'clock we drew seventeen couple, and started not very cheerfully. When we got to Brampton some of them looked like drums, so we shut them up at Sanders' house. The moment the hounds were in covert a great banging fox came out across the 
middle of the field. The hounds got a capital start. There was one big black dog, a very hard runner, that had not been fed; he got away first and was first all day, and the others ran after him. They ran for an hour without a vestige of a check into Grafton country, through Salcey Forest. As I opened the gate at the top of the ride I saw the fox cross at the bottom of the ride and the hounds about a hundred yards behind him, and they ran into him in the next field outside the wood. About the middle of the run Harry Sanders got into a ditch with a horse called "Absalom" on the top of him, and I believe Lord Spencer assisted at the rescue, and afterwards bought Absalom. He was heard exclaiming, "Help! help! I'm $d-d$ if I shan't be killed ! Oh, my poor children!" We had a long way to go back into our own country, and I did not do much more in the afternoon.

5th December.- "Valeria" plopped into a brook at Lilburne, and wet me through up to the chin. I was very hot at the time and it took my breath away. I never knew before the meaning of a chill. I woke in the middle of the night and couldn't turn over in my bed. However I got better in the morning, and got on a pony at twelve o'clock and went out to look for the hounds.

The year 1867 began with a very hard frost, which lasted a fortnight.

April 2oth.-My father-in-law, Rev. J. Hamilton Gray, died in London. He was rector of Burton-inthe-Wold and Rural Dean of Chesterfield. 
April 22nd.-Heavy snowstorm.

April 27th.-Mr. Hamilton Gray was buried in the crypt at Glasgow Cathedral. He had been interested in it, and had put up two memorial windows there.

I did not hunt again this season, and went to Charleton.

I 7 th September, I 867.--My wife and I, Kit, Jack and Charlie, with Elise, the French maid, started from Brigstock for the Paris Exhibition. We got to Folkestone on the i 8 th. It was blowing very hard. On going on board the steamer the steward said, "Will you have a waterproof?" I saw that all the other passengers had them, and when we started with a head wind the boat just dived through the first wave, about three or four feet of water rushing along the deck. The rest of the passengers had gone below except Admiral George Tryon, who was going to Egypt in charge of transport. (He was drowned a few years ago in the terrible Victoria disaster.) He and his secretary and Charlie and I, who remained on deck, were the only ones who were not sick!

When we landed at Boulogne all the children were wet through, and as we had cleverly plombeed all our luggage to Paris, we could not get any dry clothes. So we had to put them all to bed while their things were drying.

Next morning we went on to Paris to the Clarendon Hotel, and changed from there to the Hôtel Mirabeau. We went to the Exhibition every 
day. The chief thing we did was to drink American cocktails and go to the circus in the evening. We came back to Folkestone on the 26th. Jack went back to Eton, and we returned to Brigstock.

"Fawsley.

"My Dear Thomson,-

"About twenty-five years ago the Master of the Pytchley, with the concurrence of the principal members of the hunt, gave Lord Southampton (who at that time hunted the Duke's country) permission to draw all my father's coverts, with the exception of Dodford Holt ; for twenty years he availed himself of it and drew Badby Wood regularly. That permission has never been withdrawn to my knowledge by any master of the Pytchley; but Lord Spencer, when he kept them privately, intimated to me that it was a privilege he did not wish to see made too much use of, and consequently, as he drew this side of the country very fairly, the Duke of Grafton very seldom drew Badby Wood, although he did so on one or two occasions during Spencer's mastership. As I thought you might be ignorant of all these circumstances (and your letter clearly shows you were so), I sent you a message by Craven, that you might apply to me for information rather than to the Duke of Grafton, who is as unlikely to infringe any hunting law as I should be to ask him. But my coverts in Preston Charwelton and Everdon have never been drawn once this year by you; Badby Wood and Dodford only twice. We have now 
arrived at the Ioth of February; we are eaten up with foxes; the lambing season is coming on, and it is quite impossible for me to prevent the foxes being destroyed if they are never hunted. Under these circumstances I think it will be better. for all parties that you should not withdraw a permission which has not been taken away by any of your predecessors for a quarter of a century, and trust to me to find you a fox whenever you condescend to draw my coverts.

"Believe me,

"Yours very truly, "Rainald Knightly."

One day we met at Dob Hall and found in Brampton Wood. After running some time hounds divided. Dick went to stop one lot; the body went away past Dingley, over the stiff country by Braybrook, Oxendon, under Clipstone Hill to Hothorpe, Bosworth Gorse, only myself and Tom Firr with them, along the banks of the canal towards Laughton Hills. Here I met Jack Topham, coming back from hunting with Tailby. I said, "Come along with me Jack, perhaps I shall want your help". When we got to the!spinnies on Laughton Hills, when I blew my horn twelve couple of strange hounds came to me, and a few minutes after Jim Bailey, Tailby's whipperin, thinking I was Goodall. The hounds ran all together into the covert, two or three times round it, and killed. Frank Goodall was on the top, I was at the bottom, and as he had to run down hill 
and I had to run up, he got to the fox first, and carried it out of the covert. When I got to him he said, "Which will you have, sir, head or brush?" I said, "Brush". After eating the fox, we said, "Be quiet, don't say a word". We turned our horses in opposite directions, and whistled quietly and the two packs separated, except one hound, one of mine.

I agreed to go on again with the hounds. Will Goodall left ist May. Mr. Herbert Langham was honorary secretary, Major Whyte-Melville having gone to live in London.

1867. 26th August.-Commenced hunting at Althorpe.

"Cottesbrooke Park, Northampton,

"February, 1868.

"Sir,-

"At a meeting of subscribers to the Pytchley Hunt, held at Brixworth on February IIth, the following resolution was proposed and carried for season 1868-69:-

"'That Captain Thomson's offer to hunt the country four days a week in the open, and the woodlands in the usual way during the spring and autumn, for the sum of $£_{3}, 000$, be accepted, provided such sum can be obtained. The open country to include Brampton Wood, Rushton, Boughton and Weekly Hall Wood.'

"(Signed) Herbert Hay Langham."

March I868.-Hourds met at Rockingham 
Castle. There was a long broad avenue which went down to Dene. As I was moving off with the hounds, Lord Cardigan rode up to me and said, "You have known me many years". "Yes, sir." "I have always been a very healthy man." "Yes, sir." "Just now I got a fit of giddiness. I'm not well ; I'm going home-Good-bye," and he rode away slowly towards Dene. About an hour afterwards, when we were near Dene, he came back with his mackintosh on. I said I was glad to see him again. He said, "I felt better, so I thought I would come out for a little while".

One of his keepers lived in a lodge on the avenue; his name was Simon Bell. A gun burst in his son's hand and injured his fingers. Lord Cardigan rode out to inquire for the boy, and was found dead on the ground and his horse standing beside him at the gate. I believe that he had fallen off in a fit, and that the first symptom of it was when he told me he was giddy a few days before.

I $3^{\text {th }}$ March, I868.-Prince of Wales at Althorpe; met at Maidwell. The Prince of Wales came down from London to hunt. Found at Berrydale, ran through Maidwell Dales, a ring round by Scotland Wood and Kelmarsh to ground near Maidwell; did not get him. Found again in Scotland Wood, ran well by Kelmarsh Spinnies up to Clipstone, and killed. On to Langborough, which was blank; found at Sunderland Wood, passed Blue Covert on our left to Faxton Corner, where we got 
up to him; ran on to Mawsley Wood and Old Poor's Gorse. I was on right side of fence with line of gates, Prince on left side, posts and rails, which he jumped most gallantly. Dined at Althorpe. After dinner I was sitting next the Prince, Spencer on his left. The Prince's servant brought his cigar case, which he handed to Spencer. He took one, although he hates smoking. The Prince turned to me and said, "I know you never smoke," and passed it to the next. It was pretty hard work dining out after hunting.

Next day we met at Stowe Nine Churches. I was at Althorpe with the hounds about half-past nine. The Prince came out and said, "How are you this morning?" "Fresh as a four-year-old, sir." He said, "I never was so tired in my life". He had not been hunting much.

We drew Badby Wood, and a great badger crossed the road in front of me. I tried to make the hounds hunt it, but they would not. I forget what we did; but we ran through a village, down a footpath with a stiff stile into the road. I jumped it on "Iris," and the Prince followed me. We had a capital run up to Shuckborough, late in the afternoon. The Prince left there, and went to London by train. Hounds got on a fresh fox and ran down to Ladbrook Gorse in Warwickshire country. I stopped them there, almost dark. I got home at ten o'clock; hounds a quarter-past twelve.

Ist August. - A volunteer review took place at Perth, Colonel Bulwer, C.B., commanding. On 
arriving, the Fife Mounted Rifle Volunteers marched to the barracks; the horses were fed in the ridingschool, and the officers and men were hospitably entertained by the 8th Hussars, a squadron being quartered there under Captain Mussenden.

In Yorkshire, Weatherby Show took place on $5^{\text {th }}$ August. I went and stayed at Bramham with George Lane Fox, and got first prize with "Iris" and second with "Borderer".

“6th August, 1868.

“My Dear Thomson,-

"I hope to hear nothing is good news, and that Mrs. Thomson is much better, and you relieved from anxiety about the winter.

"Your beginning the new house was a good sign. Our movements would depend to some extent on yours, for if I had to take a more active part next season, which I devoutly trust will not be the case, I should like to get home to settle early in November, and be on the spot to see how things go on in the woods. It would therefore be a great relief to me to know I need not think more about this.

"We are much bored at being away from Althorpe this glorious weather, but we have a charming villa very suitable for my work at Woolwich. When not on my committee, I feel the want of interests about the place and neighbourhood, which is very Cockneyfied, covered with a network of villas and their gardens.

"I hope these fine showers may save a few voL. I. 
turnip-fields. The ground is so hot, directly rain saturates it, every seed will be forced into growth as though in a hotbed.

"Very truly yours,

"SPEnCER."

"The Nelson" was a very tight fit for us, and noisy, being in the street.

My wife had never been well since her father's death, and during the winter at Brixworth was very unwell, and towards the end of the season she was confined to her bed. I wrote to my sister, Mrs. Montgomery, at Lillington, and said "if she could not come to help me I should have to shut up". Jack was at Eton, Charlie at Mr. King's at Brighton, the girls and Bill were with us, and only Elise, a French maid, to look after them. Mrs. Montgomery came to us, and her husband got a bedroom in the saddler's house.

Lord Overstone had a house at Great Houghton which had been a school, and happened not to be occupied, and he most kindly lent it to me. Lord Spencer lent me his omnibus, and we moved Mrs. Thomson there, end of April. We had to carry her downstairs in her bed. She got better while at Houghton, and used to sit out in the garden; and we had very nice neighbours in the Rev. J. Gregory and his wife. She was sister of John Stone, my old Eton friend. We remained at Great Houghton all the summer.

Commenced hunting at Boughton on 25th 
August. Rev. Mr. Wicks came out on foot with a pint bottle and a broken wine-glass and gave me a glass of cherry brandy.

During the summer of $1868 \mathrm{I}$ got possession of the cottage at Brixworth on a lease of five years, and Mr. Wood, my landlord, agreed to lay out a year's rent on improvements. I set to work on it, and built the drawing-room and a staircase, and just succeeded in getting into it at the beginning of the hunting season.

Edward Goode, the builder in Brixworth, undertook the work, and was a first-rate workman and excellent man. I used to ride over every day from Great Houghton, and all the stablemen used to work as masons' labourers in the afternoon, their only pay being some pints of beer. They got on well with the work, as we got into the house on I 2 th November. The plaster was not quite dry and used to sweat at night; I used to wipe it down with a rough cloth. Then Bill got an attack of bronchitis; we were able to keep him in the old part of the house with a curtain across the passage.

My wife was very unwell during most of the winter, and I did not like to disturb her in the morning. I waited till the last moment, and then galloped all the way to covert. I went to Misterton, sixteen miles, with two hacks, and did it in an hour and ten minutes. 


\section{CHAPTER XXII.}

SALE OF PYTCHLEY HORSES AND LEATHAM GRANGE.

ON 9th January, I 869, the hounds ran into the coverts at Dene while a shooting party was going on. Next day I wrote to Lady Cardigan :-

" roth January, 1869.

"My Dear Lady Cardigan,-

"I am very sorry that the hounds yesterday ran into one of your coverts and disturbed the sport of your friends who were shooting there. I could have prevented it ; but the hounds were in the middle of the covert before I was aware that there was any shooting. I hope that we did not very much interfere with their sport. We found a fresh fox in the covert and another in Oakley purlieus, which we also ran through.

"Believe me,

"Yours very truly,

$$
\begin{gathered}
\text { "J. A. T." } \\
\text { "Dene, } \\
\text { "13th January, r869. }
\end{gathered}
$$

"My Dear Mr. Thomson,-

"Many thanks for your kind letter. Your hounds did no harm whatever. I should be only too 
glad to see them a little oftener. Formerly, when Lord Spencer hunted them, he gave Lord Cardigan leave to ask Mr. Fitzwilliam to come occasionally (about once in three weeks) during February and March until the Pytchley came to Bristock, which was a great aid in getting rid of the numerous foxes in my woods, but of course I should not like to ask your consent unless it were perfectly agreeable to you. I only mention it now because last week Mr. Whyte-Melville, who came to see me from Bulwich, told me he thought you would not object.

$$
\begin{aligned}
& \text { " Believe me, } \\
& \text { "Yours very sincerely, } \\
& \text { "Adeline Cardigan." } \\
& \text { " Milton, Peterborough, } \\
& \text { "22nd January, I86g. }
\end{aligned}
$$

"Dear Thomson,-

"I received a letter from Lady Cardigan to-day enclosing one from you to her, in answer to a request she seems to have made that I might be allowed to hunt the Dene woods. Of course, I don't know in what terms the request was made, but the idea did not originate with me, for Lady Cardigan asked me some time ago to go and hunt at Dene, and I was obliged to remind her of the etiquette which M.F.H.'s are expected to show as regards hunting, and that I could not without special permission invade a neighbouring country.

"However, your answer to Lady Cardigan has set the matter at rest to the end of your mastership 
of the Pytchley, which I am sorry to see is so near at hand.

"We killed one of your foxes to-day after a very good hunting run over the fine grass country between the woods. I hope you have had good sport. We have had better than I ever remember-the bad days are quite the exception.

"Believe me,

"Yours truly,

"G. W. Fitzwilliam."

I 869. - The Duc de Chartres when staying at Althorpe was out hunting a few times. He was a capital fellow, very keen and handy; would jump off to open gates and make himself useful. When he went away he sent me a beautiful book on hunting, in three volumes.

"Morgan House, Ham, Surrey, " Igth February, I869.

"My Dear Sir,-

"I take the liberty of forwarding to you by rail a copy of M. de Noirmont's History of Hunting in France. When I was last at Spratton House we spoke of that book; and I hope you will accept it as a remembrance of the days' sport I have enjoyed with your hounds.

"Pray believe me,

"Yours very truly,

"Robert d'Orléans

"(Duc de Chartres).

"Captain J. Thomson,

"Brixworth." 


\author{
"Brixworth, \\ " 2oth February, 1869.
}

"Dear Duc de Chartres, -

"I beg to return your Royal Highness my sincere thanks for your kindness in sending me that beautiful work on hunting, which I received this morning. I assure you that I shall study it with much pleasure and value it most highly as a memento of having had your Royal Highness as a brother fox-hunter. If I have an opportunity I shall beg you to do me the honour of writing, your name in it. I hope I may again have the pleasure of seeing you out hunting before the end of the season, which, I am sorry to say, is my last as Master of the Pytchley.

"I have the honour to remain,

$$
\text { "Yours very truly, }
$$

1869.--On giving up the Pytchley Hounds I had many offers to take other countries.

North Warwickshire.-Jenings' letter :-

"Milverton Farm, Leamington,

"I3th February, I869.

"Dear Thomson,-

"How would it suit you to take the North Warwickshire country, as Mrs. Thomson is in delicate health? You could get good house here, amusement, and plenty of medical advice for her; also be able to hunt two days a week with the Pytchley; and your 
doing so would confer a great favour on our hunt committee (of which I am one) as well as on the hunting people here generally.

"Be kind enough to send me a line at your convenience, and oblige,

$$
\begin{gathered}
\text { "Yours very truly, } \\
\text { "J. F. Jenings." } \\
\text { "Shardeloes, Amersham, } \\
\text { " } 23 \text { rd January, t869. }
\end{gathered}
$$

"My Dear Thomson;-

"My parson comes from London, and tells me he hears you give up the Pytchley. You will, like me, be miserable without hounds. Have you any fancy to hunt a bad country, with a good subscription (about $£ 2,000$ per annum; kennels, hounds and stables found), as this country will be vacant in a few days? I am not authorised to offer you this country, as I do not think any one but myself knows that it will be vacant. But when it is, I have a good deal to do with choosing the Master, as several landed proprietors will do what I advise. Don't mention this till you have written to me, and if you fancy it, wait my answer.

$$
\begin{aligned}
& \text { "Yours very truly, } \\
& \text { " T. T. DRAKE. }
\end{aligned}
$$

"Three days a week."

New Forest._Lindesay Shedden and Martin Powell's letters :- 
"Private.

"Delawarr, Lymington, Hants; "I 8th February, 1869.

"My Dear Thomson,-

"I understand you give up the Pytchley at the end of this season; that one reason for your giving up is on account of Mrs. Thomson's health; that she requires a milder climate. I believe the New Forest country is vacant, and it may appear absurd asking you to take it, for it is certainly a wretched country, and a good deal spoilt since the days I hunted it; still it is a good scenting country, and a man so fond of real hunting as you are might be tempted to try it. It is a cheap country to hunt, and if a man would hunt it four days a week, always hunting one day a week the north side of the country, Salisbury and Romney side, I think he would get a subscription of close on $£_{1}, 000$, and it would not cost more than $£ \mathrm{r}, 200$, so that the Master would not be much out of pocket, particularly if he hunted the hounds himself, which of course you would do.

"I am glad to hear you have shown such sport in Northamptonshire. I very seldom see a pack of hounds now-sometimes Billy mounts me. He still goes out, but I should say more for exercise than anything else, as he hardly ever sees a hound after they find; still he enjoys it in his own way. He has got a capital house, Wortley Park near Winchester, and lives very comfortably. 
"Mrs. Shedden joins me in kind regards to you and Mrs. Thomson, and hopes she will improve in health in a milder climate.

"Yours very truly,

"Lindesay Shedden.

"P.S.-There are kennels and stabling for about twelve horses belonging to the country. There are two other persons after the country, so let me have a line as soon as you can, saying if you entertain any idea of it."

"Shrubs Hill, Lyndhurst, "22nd February, r 869.

"Sir,-

"I am desired by the members of the New Forest Hunt to say that in consequence of the present master of their Hounds having given notice of his intention to discontinue hunting the country at the end of the present season, they are anxious to offer the country to you.

"A New Forest Hunt meeting is fixed for Friday, the 26th inst., and I shall feel greatly obliged to you if you can possibly let me hear from you on the subject in time to lay your letter before the meeting on that day.

"I have the honour to be, Sir,

"Your obedient servant, "W. Martin Powell, "Hon. Sec. N. F. H.

"Tо John Thomson, Esq.,

"M.F.H." 
V.W.H.-Wharton Wilson's letter :-

"Private.

“Dear Thomson,-

"Ablington, Fairford, " 28th January, I869.

"If you are really leaving the Pytchley, and intend hunting any other country, will you come here? I have not as yet said a word to any one of my intention, but I must be out of it at the end of the season. My father is getting an old man, and I want to be more independent and able to be with him than I am.

"Now, I have got a capital pack of hounds, and will either lend them to you for three years, leaving them entirely under your control, or sell them to you. I think the people in the country are well satisfied with them. All is as straight and right as can be, and there are plenty of foxes everywhere. The subscription $£ \mathrm{I}, 100$, and the hounds, stables and country free.

"A house could be got at Coates, which is a mile and a half from the kennels. If you think of this, come down to me, and I will tell you all I know unreservedly. I have no intention of giving up my place here, but only want to be more at liberty than I can be now. Kindly consider this private, at all events for a week.

"Yours sincerely,

"Matthew W. Wilson."

Tedworth.-Letter from Lord A. St. Maur, afterwards Duke of Somerset :- 


\section{"Wilcot Manor, Marlborough, \\ " 17 th March, 1869.}

“My Dear Thomson,-

"A friend of mine, a member of the Tedworth Hunt, begged me to ask you whether you wished to have another country on leaving the Pytchley. This is quite private, as I have no authority to move in the matter. These hounds hunt four days a week, Monday, Tuesday, Thursday and Saturday. The subscription is about $£ \mathrm{I}, 600$ a year, Lord Ailesbury and Sir Edmund Antrobus being the chief subscribers and supporters of the hunt. The country is about half down and half enclosed, with two very large coverts of nearly 2,000 acres each; the fences are very small indeed, and scarcely deserve the name.

"Hoping that you are quite well and have had a good season, with kind remembrance to Mrs. Anstruther Thomson,

"I remain,

"Yours very truly,

"Algernon St. Maur."

All these offers I declined.

Towards the end of the season, April, I869, a deputation of farmers, headed by that grand old sportsman, Matthew Oldacre of Clipstone, called on me at the cottage at. Brixworth with the following address :-

"We, the undersigned farmers, graziers and occupiers of land in the Pytchley country, 
having heard with extreme regret of your resignation of the mastership of the hounds beg most earnestly and respectfully to entreat your reconsideration; but whatever may be your final decision, we wish to express the esteem and regard your undeviating gentlemanly bearing has won from all, and the high appreciation we have formed of the sportsmanlike manner your mastership has displayed."

Here follow nearly two hundred signatures. In reply to the requisition I wrote :-

"Gentlemen,-

"BRIXWORTH, " I4th April, I869.

"I beg to thank you for the compliment you have paid me. I regret that the reasons which induce me to resign are so important that it is not in my power to alter my decision. I can now only repeat my thanks to you for the kind expression of your approbation, and I assure you I shall always have a grateful recollection of your kindness to me while Master of the Pytchley Hounds.

"Yours very truly, "J. Anstruther Thomson."

They then started the idea of giving me a testimonial, and asked Mrs. Thomson in what form it should be. She decided a picture. A preliminary meeting took place at John Darby's at Rugby, and the choice of an artist was discussed. John Darby 
said it must be painted by Sir Francis Grant. "It just makes the difference of having your things made by Poole or being clothed by Nicholls." John Woods of Brampton kindly consented to be honorary secretary, and issued the following notices :-

"SiR,-

"June 1869.

"It was unanimously resolved that the testimonial about to be presented to Anstruther Thomson, Esq., should be a painting of himself on 'Iris,' by Sir F. Grant, and that the subscription should not be confined to the Pytchley Hunt.

"If you are disposed to contribute, will you have the goodness to fill up and sign the enclosed form. The account is opened at the Northamptonshire Union Bank. No donation to exceed $£_{55} 5$.

"I have the honour to be,

"Your obedient servant,

"John Woods, "Hon. Sec."

"Cameron House, Windygates, Fife, " 7 th June, 1869.

"SIR,-

"I shall feel obliged by your publishing the enclosed letter from the committee for presenting Mr. J. Anstruther Thomson with a testimonial on his retirement from the mastership of the Pytchley Hounds. I take the liberty of publishing the letter, as I know it is generally thought in Scotland that subscriptions to the testimonial are exclusively confined to members of the Pytchley Hunt, instead of 
being open to admirers of the great sportsman. I have only to add that I shall be delighted to be the medium for forwarding any sums I may be entrusted with for the above purpose.

$$
\begin{aligned}
& \text { "I am, etc., } \\
& \text { "H. V. HaIG." }
\end{aligned}
$$

" 27 Park Street, W., "I 4 th May, 1869.

"My Dear Thomson,-

"I have had a long chat with Frank Grant, who you will be sorry to hear is very far from well. He says he is quite used up, what with the incessant duties of the presidency of the Royal Academy and his own professional labours. He suffers great pain from neuralgia in the head, and unfortunately in the right arm, no doubt from its excessive use in painting.

"He says he cannot undertake to paint a man on a horse, as the picture, in the first place, would be enormous, and, in the next, that it would entail more labour than he could in his present state bestow upon it ; and besides, he has found the necessity of having a horse in the painting-room so very troublesome, that he does not feel disposed to undertake another picture of that class at present. It would, moreover, be 800 guineas. What he suggests is that you should be represented with three hounds (portraits) standing on a fox earth, where you had run to ground, with your cap in one hand and horn in the other. It is a grand idea, and when you consider the commanding appearance of the subject, that cheery, animated countenance which is natural to that subject, 
increased by the occurrence the picture is meant to represent, I do hope that your Pytchley friends will abandon their wish, so very natural under the circumstances, to have you, where they have so often seen you, on your favourite horse, and adopt the artist's suggestion. He says the picture would be too large for any moderate-sized room with the horse, and moreover that the one that he proposes in lieu of it would be infinitely more valuable as a family portrait to descend as an heir-loom to all future inhabitants of Charleton. However, as the dealer of the last century, Hobson, used to say to his customers, it is Hobson's choice, both as to the disinclination of the artist to paint a man on a horse and the price-you and your hounds would be 500 guineas.

"Grant asked how are you to be painted if you are going abroad, which looks as if he were willing to undertake the picture, as he proposes painting it, forthwith. I could not answer the question. Mrs. Thomson's health is your first object; but to have your picture painted amounts almost to a duty you owe your family as well as those friends you leave to their great regret.

"I am, etc.,

"Charles Earle."

"My Dear Earle,-

“ 27 Sussex Place,

"Regent's Park, N.W.

"When you asked me about Thomson's picture, I mentioned my regular charge for a fulllength was 400 guineas, and that the portrait of three hounds would be 100 extra. But on thinking over 
the matter, I feel that it is a congenial subject, and that if the subscribers cannot afford the full sum, I should be sorry that a question of price should prevent my doing it if required.

"Perhaps they could make up 450, and if they cannot do so, I would make them a present of the three hounds, and do J. Thomson on foot with the three hounds for the regular terms of 400 guineas. But they would have to pay half the sum at the first sitting.

"Yours truly,

"Francis Grant."

"My Dear Thomson,-

“27 PARK Street,

" 29th May, 1869 .

"I forward a letter from Sir Francis just received. I do hope the farmers may close with his most liberal offer. It is very natural that they should wish to see you on canvas as they have seen you on the field, but it is not to be done for reasons I stated in a former letter.

"I hope Mrs. Thomson's health continues to improve, in spite of this dreadful weather, and that the other members of your family are well.

"We had a dinner of old friends on Thursday at Sir Hope Grant's, and it would have done you good to see Melville and the Laird of Kilgraston in such spirits. As for Melville, though in years the oldest of the party, he was in joviality the youngest.

"Believe me,

" Ever very sincerely yours, "Charles Earle."

VOL. I. 
On 2nd June Mr. Earle saw Sir F. Grant. Grant agreed to do J. A. T. on "Iris" and three hounds for 700 instead of 800 guineas. Copyright to be his. Engraving to be a subsequent arrangement.

I869. - The sale of the Pytchley horses took place on Ioth of May at Tattersall's. A few days before the sale I travelled up to London with Nigel Kingscote. He asked me what I would take for the lot. I said, " $£ 5,000$ ". He said, "You won't get it". I was not far wrong.

\begin{tabular}{|c|c|c|c|c|c|c|c|c|c|}
\hline Boughton & • & $£ 36$ & 15 & o & Roland & - & $£ 110$ & 5 & \\
\hline Benjamin & & 21 & o & o & Harold & - & 252 & o & \\
\hline Amulet . & & 34 & 13 & 0 & Iris. & . & 388 & 10 & $\mathrm{o}$ \\
\hline Ladybird & - & 52 & 10 & 0 & Borderer & . & 315 & 0 & \\
\hline Birthday & . & 27 & 6 & 0 & Landlord & . & 168 & 0 & \\
\hline Cross-stitch & . & 54 & 12 & o & Rainbow & . & 420 & 0 & \\
\hline Needlewomar & & 105 & 0 & 0 & Hypothec & & I4I & 15 & \\
\hline Velocipede & . & 68 & 5 & 0 & Mistletoe & 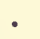 & 157 & Io & \\
\hline Sultan . & . & 54 & 12 & o & Fugleman & . & 89 & 5 & \\
\hline Moonshine & • & 63 & 0 & o & Princess & . & $23 I$ & 0 & \\
\hline Silkworm & $\cdot$ & 60 & 18 & o & Valeria. & . & 210 & o & o \\
\hline Fresco & - & 147 & 0 & 0 & Earlybird & - & 57 & I5 & 0 \\
\hline Dowager & . & II5 & 10 & 0 & Corsair . & - & $5^{2}$ & I0 & o \\
\hline Monkey . & . & 78 & 15 & o & Thunderbolt & & 84 & 0 & \\
\hline Usurper. & . & 131 & 5 & 0 & Shaver. & . & $3 I$ & 10 & o \\
\hline Regoletto & . & 64 & I & o & Hollyhock & . & 89 & 5 & o \\
\hline Moorcock & . & II 5 & I0 & o & Abyssinian & & 95 & II & o \\
\hline Wanderer & - & 315 & 0 & 0 & Philosopher & & 32 & II & o \\
\hline Fountain & & 346 & 10 & o & & & & & \\
\hline Druid . & - & 252 & o & & & & & 9 & \\
\hline Man of the & & 168 & & & & & & & \\
\hline
\end{tabular}

At the end of the season, May, 1869, I took a house at Sydenham called Leatham Grange, and Grant began to paint the picture. We remained there about two months. I bought a coach from Holland, and he lent me a brake while it was being done up. I went out one day for a trial trip with a 
team; the near wheeler was a horse with one eye, called "Bull's Eye". I bought him from Mr. Bull at Weedon. The leaders were two cobs; they had no blinkers, only head-stalls. My little daughter Kit 'was on the box with me; John Pye and Fred Welch behind. Going down a steep hill when I put the drag on, a stone got into it, and made a tremendous scream that frightened the horses. When I pulled them, "Bull's Eye" turned his head and laid in on the pole. When I raised the whip, both the leaders jumped forward, and I had a real handful. "Bull's Eye" kept edging the coach to the side of the road, and it slowly and quietly went up the bank till it toppled over. Kit flew away, with her hair flying into the air; I followed her, and landed on my side in the middle of the road. I didn't leave go of the reins; they dragged me a yard or two and stopped; both the men tumbled out behind. We got two or three men to come and help us, and lifted the brake on to its wheels again. There was nothing broke except the lamp iron. In the meantime Kit had collected all the hats and put them in a row along the side of the road.

On leaving Sydenham I took Lady Norbury's house, on 9th July, in Onslow Gardens, next door to George Whyte-Melville's, and used to sit in the garden after dinner with them.

Sir Francis began the picture while we were at Sydenham. I rode "Iris" round his garden, in Regent's Park, while he made the first sketch. It was about fifteen inches square; and his brother, Sir 
Hope, gave him $£ 100$ for it. He used to take me and "Iris" alternately, one before lunch and the other after. "Iris" got so used to it, that he walked up to his own place in the studio and stood on the mat.

I used to have lunch with Lady Grant. One night I dined with them, and sat next Little Gilmour. I saw Sir Francis watching me, and he said, "I have it". Next day when I went to the studio, he had painted in my face.

One day Sir Edwin Landseer came in. $\mathrm{He}$ shaded his eyes with his hands and said, "A fine broad piece of painting, Grant; I should continue that road up to the sky line". "Do it yourself," said Grant. Sir Edwin took a dab of paint on his finger and finished the road. He also said, "I should put some more light behind the horse," and took up a piece of white chalk and made crosses. Sir Francis had painted my hand, holding my cap, very carefully. One day his son, Colonel Grant, came in, and said, "Who ever saw a gentleman out hunting without gloves?" and he painted a dogskin glove on it. When he was painting the reins on "Iris'" bridle, I said, "That rein is twisted". He said, "I am d_- d if I am going to alter it to please you". Next time I saw it it was altered.

When I and the horse were finished he had the hounds up in London, and kept them in a loose-box. I used to walk them out in Regent's Park, much to the astonishment of the nursery-maids. When old "Rallywood" was led in, and saw the picture at the 
other end of the studio, he thought that I was there, and began whimpering and jumping about, lashing his stern. Grant said, "It was the greatest compliment ever was paid him".

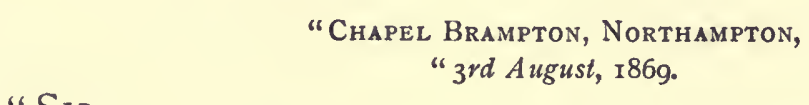

"Sir,-

" 3rd August, I869.

"Our account at the bank keeps increasing, but not very rapidly; there are several more subscription lists to be sent in which I trust will raise the amount to the sum required. I am delighted to hear so good an account of the painting. My neighbour, H. Sanders, called upon Sir F. Grant the other day, just to have a look. He told me he thought the likeness of both 'I ris' and yourself perfect. I have been hoping 'Damon' may be one of the hounds chosen to represent the three favourites of the Pytchley kennels.

"I wrote to Mr. Mills the other day, but have not received an answer. Do you know if he has left his seat in Norfolk? I want to write to him again. I heard from Mr. Hugo Haig the other day, and sent him a few circulars to assist him in collecting subscriptions, for he said he should very shortly be going into Aberdeenshire for a few weeks' shooting, and then should require the circulars.

"If you should wish to see me when at Brixworth please drop a line and I will trot over any morning.

"Your obedt. servant, "John Woods.

"J. Anstruther Thomson, Esq." 
Henry Dixon, "The Druid," came to Charleton on 4th February, r 864. I had made his acquaintance at the Redcar Hound Show. He was a very clever fellow, and was the first who instituted the practice of "interviewing". He bought a pony in Shetland, and rode it all the way to London. It did not kill the pony, but it caused his own death, for he got an attack of bronchitis from which he never recovered. I met him at the New Inn kennels. I don't know where he left his pony. He had a very light kit, for he bought a pair of worsted stockings in the village.

He gives a description of the Fife Hounds in Field and Fern, published in 1865 , and in the preface says he returned home in the snow on a February night with an Orkney garron, fourpence in his pocket, and two fat little note-books. He was collecting materials to write Saddle and Surloin. It took him three summers, one winter and one spring. He travelled 8,000 miles, and was away from home 250 nights before he wrote a line. $\mathrm{He}$ was at Charleton the year before the book came out. During the Islington Horse Show he was brought into the secretary's room speechless and in a fainting condition. He whispered to me, "I shall be better presently". I got him some tea, and remained with him till he somewhat recovered.

Letter from "The Druid" :-

$$
\begin{gathered}
\text { "Io Kensington SQuare, } \\
\text { "London, W., 22nd January, } 1866 .
\end{gathered}
$$

"Dear Sir,-

"Would you kindly drop me three lines to say how sport is with you. Field and Fern gets on 
very fairly considering that the rinderpest is dead against it, and hardly a Scotch editor knows what to make out of such beef and mutton, greyhound and foxhound worship. One was very much disgusted at the prominence given to Joe Graham in Dumfriesshire hunting (because Mr. Carruthers has no individuality about him, and wouldn't act as a 'head centre'). Hence it says with great scorn, 'Joe Graham, who figures in their pages as the leading man in the country'.

"I was near Donnington, alias Rackrent Castle, the other day. The presentation of Bibles on two different occasions by the tenantry does not seem to have effected much. The Sundays, I am told, are fearful. I never heard of such extravagance. They do say the pony races, etc., cost $£ \mathrm{I}, 500$. They took their own champagne to the Ashby ball, and one or two of the party never got further than a private room, where they sat and enjoyed the champagne. Then the Marquis slipped an open knife into a friend's coat pocket unawares and caused him to cut his hands. Such are the floating stories of this much degenerated Donnington.

"I am quietly going through the English counties for another look, and have done five. What with those three heavy Scotch summers and asthma I have had the steel pretty well taken out of me, and cannot work as I did, when I sent every proof to Fawsley.

"Poor old Sir Charles would have gloried to see the Pytchley in the form you have them once more. 
"I stayed a night with Captain Williams lately, and had a very merry day with the Jesuits at Stonyhurst - a great dinner and plays at night. I never saw such a jolly set of men when they really unbend among themselves. Sir Charles Tempest had just died there 'in retreat'. They smiled when he came, and said he looked well, but he told them he had only a few days left, and he lived five.

"Faithfully yours,

"Henry Dixon."

"Dear Sir,--

"Io Kensington Square, W., " 18 th February, 1867.

"Would you kindly, if it is not asking you too much, drop me a line on your off day to say what you are doing? I see the great run's memory is to be embalmed in a Waterloo Gorse Stakes. I found my wife (and never changed on the line) within a quarter of a mile of that cover, so from different reasons I have as great a respect for it as you can have.

"I have had a fearful fight with asthma these last three months, but it fairly wore me out with gasping and sleepless nights, and now I cannot walk across a room without holding by somebody and blowing like a steam-engine, so for eight days I have been in bed propped up with a bed-rest, and I know not when I shall leave it, as the slightest turn or twist affects the throat. Night and day are much the same. I sleep when I can, like a poacher's dog more by day than night, and I write this at half-past 
three A.M. by my night lamp. Oh! the dreary sameness. I seem the mere sickly shadow of the queerly dressed enthusiast who bustled about Scotland among bullocks and rams A.D. 1862-64. However, it is my lot, and I must bear it, and I may get all right again with rest. I am so glad that I was in Scotland when poor Hall Maxwell was in his prime as well as old Dick, whose successor has soon departed.

"Faithfully yours,

"Henry Dixon."

" 59 Warwick Gardens, Kensington,

"London, W., 2gth October, 1869.

"Dear Sir,-

"I have forwarded you the Gentleman's Magazine with your little article in. Is 'Weekly Hall Wood' right? I think there should be a slight notice of the great Waterloo Gorse run-a slight sketch of it, your notion where you changed foxes, the hounds which did best, and 'sich a getting home,' etc. - to make the thing complete. Poor Fred Thursby, clergyman at Abington Abbey, is dead. I think you must have known him-a martyr to gout, which attacked his kidneys. Such fun at the harrier sale. The Windsor people were quite excited. An eighteen-year-old white mare, which was expected to go at 35 guineas for a brood mare, made 9I guineas. Her Majesty has never liked them ever since Prince Albert had two tumbles in her august presence, and was taken home out of fair pity in the carriage. They won't keep on the old hunts- 
men I am told. Poor Bill Orvis of the York and Ainstey had the accidental insurance papers in his house, but he put off signing them, and so his wife has lost $\mathscr{E} \mathrm{I}, 000$. The subscription will not make that up. Poor Robinson hit that company hard, once for a broken leg, again for brain concussion, and for $£ \mathrm{r}, 000$ when he was drowned. There seems something still a little mysterious about Clark leaving Badminton, but I fancy that he had grown very incompetent in the field, and his riding especially bad. I don't think Lord Kesteven's man quite likes his berth.

"We wanted 'Iris' sorely at Beverly for that roo guinea cup; but still the ring would hardly have been large enough for him, and none of the judges saw what John Elliot saw, that to find 'Lady Derwent' out, you must give her a straight-away gallop, not keep her to circus business, which she knows to a nicety. I saw the Rev. Everett, master of the B.V. Harriers, at Tattersall's, and asked him if he had squared the new Bishop of Oxford; but he says he has worn his green coat and red waistcoat under four bishops in that and three other dioceses, and cares for none of them. He is Morell's brother-in-law. I hope to have the first volume of Saddle and Surloin out in a few weeks. well,

"Trusting that Mrs. Thomson continues pretty

"Believe me,

"Faithfully yours,

"Henry Dixon. 
"You passed me two or three times in the twilight last summer driving in these parts. I was on the wrong side of the top of the omnibus once, or you would have stared to hear the familiar cobbler sound, Good-night, Capting! ${ }^{1}$ Your driving and my riding road north quite differ. I rode by Kendal, Settle, Bromley, Manchester, Buxton, Derby, Leicester, Daventry, Worcester and St. Albans."

My son wrote the following account of the Queen's Staghounds :-

"Dear Papa,-

"Eton, Tuesday,

"27th October, 1869.

"As I was standing looking on at a match to-day, about twenty minutes to dinner time, I heard something which sent a thrill through my carcase, and after listening for a second I said to Lyttleton, 'If those arn't hounds my name is not Thomson,' and I bolted to see them. When I had run nearly to Surley Hall across country, I heard the horn and saw the hounds. By that time it was about dinner time, but I forgot all about dinner as soon as I saw the hounds. I ran on and saw a crowd standing on the river bank, ran up and saw the deer swimming down stream with three punts after him and two whips on their feet each side of the river and a crowd of cads. I think they made more noise than when a fox breaks before the Pytchley cobblers-everybody yelled and nobody seemed to

${ }^{1}$ The greeting of the cobblers as I passed through Long Buckby in the dark on my way home from hunting. 
know what to do. One chap in a punt made a dab under water and caught hold of the deer's hind leg, and very nearly drowned it, for it was so blown. Then the row became louder, for the whips holloaed and swore, the cads yelled to the fellow to hold on, and between them all the poor brute was pulled to land near dead, and a cord round his horns was pulled by some chaps and the deer came up the bank; then they capped the hounds on to him while two chaps held him. King and the hounds galloped up as if they were going to kill him at once, but only one hound offered to touch him, and flew at his nose and hung on. The hound was the best they have got, called 'Warrior'. I asked King what he was going to do with him, and he said he would have him killed when he went home because it was such a brute. It swam from Surley Locks down to Athens Bay with half the pack in the water. They went home immediately afterwards. Wickham, Charlesworth and Harris were the only Eton fellows there. Wickham is Mrs. Gregory's nephew. He said that it did one good to see a red coat again, although it was all covered with 'brass'. They begin regular hunting on Tuesday.

"I believe they are going to build new kennels here for the beagles, and it will be much better, as half the fellows don't bring them on account of kennel lameness. The kennels are at present twenty yards from the river, and in it during the floods. What could it be done for? Currey (captain of boats) says he will have it done if it costs under thirty 
shillings; there must be room for twenty couple of hounds. I wish they would make me a whip, but only fellows in fifth form are. Give my love all round.

"Your most affectionate son, “J. St. C. Anstruther Thomson."

An account of a leopard hunt by the Madras Hounds :-

I 869. - "The Madras Hunt, which has long been the best-supported establishment of the kind in India, and is still a very flourishing institution, was started early in the century, but had been allowed to expire for want of funds about the year 1856 . It was re-established in 1862 by Mr. Dalyell, and during his ten years' tenure of office there was no lack of funds, the annual subscription list sometimes reaching the good sum of $£ \mathrm{I}, 500$. This enabled him to put the establishment on a thoroughly efficient basis as a three day a week pack, and also to make a most salutary change in the system of management. It had always been usual to sell off the pack at the close of the short Madras hunting season of four months, and to purchase a fresh pack each year from -England; but during Mr. Dalyell's mastership it was arranged that the pack should also hunt the Neilgherry hill country for a portion of the year, and return to Madras in November. On these hills, 5,000 feet above the level of the sea, there is a plateau of grass, about twenty-five miles square, very similar in character to the downs at Brighton, but more.interspersed with small woodlands, which form 
excellent coverts. The climate is magnificent all the year round, the glass rarely reaching freezingpoint on the coldest nights, and the hottest weather never exceeding the heat of an Italian summer.

"Such an addition of country was an enormous benefit to the Madras Hunt in all respects, but it was also the cause of the institution obtaining at one time a world-wide reputation, and the notice of all the sporting journals of England and America, for here it was that occurred an incident quite without parallel in the records of sport. On 22nd June, I869, the hounds had had a fair run, and killed their jackal (which animal in India does duty for a fox), but had given the whole of the field the slip except two gentlemen who were doing what they could to get them towards home. Suddenly a full-grown leopard dashed out of a thicket and crossed the path, which was too much for the uncontrolled pack, for in a moment the whole thirteen couple were after him at score. They hunted him for some little distance and eventually turned him over, in the open, on a grassy hillside, in full view of the two gentlemen in question. Every hound was at him on the ground, and would undoubtedly have then and there made an end of him, had it not been for the extraordinary toughness of his hide, which they could not quite get through, so that he was at last enabled to regain his legs and shake off the pack, and, after a further exciting chase, to take refuge under a rock on the edge of a stream running through a small copse of brushwood. Here the hounds regularly bayed the 
beast, forming a semicircle round him, and receiving his charges hither and thither in the most gallant manner. After some little time the huntsman and the field came up, and for upwards of half an hour every endeavour was made to whip off the pack, as the greatest fears were felt for their safety, especially as it was noticed that many of them were already severely wounded. Some few of the hounds were got together, but nothing would induce many of that thoroughbred little pack to leave their quarry until a gentleman who had succeeded in obtaining a rifle discharged it at the animal. The report had hardly been heard and the smoke had not cleared off, before every one of the pack which had hitherto been most forward in the attack had trotted quietly out of the copse in the most dignified way and rejoined the huntsman, evidently considering that if guns were to be used their business was at an end. It was stated at the time, by an eye-witness, that there was an air of calm contempt about the whole demeanour of these hounds, even to the manner in which they carried their sterns and ears, as they trotted out of the wood when the gun was fired, which was most amusing to watch. On an examination of the pack it was found that the whole thirteen couple were alive, and only some three couple severely injured, though many of the others were bitten or scratched. The number and dash of the assailants seems to be the only explanation of such an escape from so powerful and savage an animal, as one stroke of his paw would have undoubtedly killed the strongest 
foxhound ever bred. The rush, however, of twenty-six hounds on different sides whenever the leopard turned in any one direction seems to have left him neither time nor presence of mind for a single well-directed blow or bite. Eventually, when a second shot put an end to the animal's life, he was found to be a full-grown leopard, measuring seven feet and weighing 7 st. $4 \mathrm{lb}$.

"The pack which performed this wonderful exploit was almost exclusively from the Pytchley kennels, as Mr. Dalyell was in the habit of obtaining an annual draft from his relation, Mr. Anstruther Thomson, but it is satisfactory to all who are interested in the 'Kingdom of Fife' to be made aware that the one hound which was most distinguished on the occasion was 'Royster' by Fife 'Sportsman,' out of Fife 'Dairymaid,' a three-year-old dog which had been two seasons in India.

"The skin of the leopard was retained by Mr. Dalyell as a trophy, ibut the head of the animal, handsomely mounted by Ward of Wigmore Street, was presented to Mr. Anstruther Thomson by the members of the Madras Hunt as a suitable acknowledgment of their appreciation of his kindness in supplying them with hounds of such wonderful stamina and pluck."

\begin{tabular}{llll}
\multicolumn{3}{c}{ 1868. - Hounds PresenT (13 Couple.) } \\
Tarquin. & Dimity. & Gaudy. & Darter. \\
Gaiety. & Marksman. & Boscobel. & Driver. \\
Genial. & Sampson. & Limner. & Royster. \\
Fleecer. & Prowler. & Lively. & Hasty. \\
Harriet. & Clovis. & Bouncer. & Druid. \\
Gilder. & Shiner. & Purity. &
\end{tabular}

And three others, names not known. 


\section{APPENDIX}

Colonel Tremayne wrote to me on 6th December, $1903:-$

"Percy Smith and I, on the morning of the battle of Balaclava, inhabited the same tent. We turned out long before daylight. In the hurry and dark he could not find an iron guard he used to slip over his wrist to save a sword cut, for, you will remember, he shot some of his hand off in Ireland and could not draw his sword. He went perfectly defenceless as far as any one in the charge-very cool and collected, and returned safe, with his tunic torn by a lance. ... In the morning early, when we were retiring by alternate squadrons from Canrobert's Hill, and when we were halted and fronted, a shell pitched within a few yards of Percy, who as acting adjutant was on the right of the regiment. I saw the beastly thing pitch. Percy never moved his horse an inch, which he might have done as adjutant, but called out 'Eyes front, men!' The shell burst, but hurt no one."

My wife having asked Percy Smith's permission to publish Colonel Tremayne's letter, received the following reply :-

"16th December, 1903.

“Dear Mrs. Anstruther Thomson,

"I return your extracts from Tremayne's letter. Pray make whatever use you like of them in the Reminiscences.

VOL. I. 
"It may perhaps interest Jack to hear the rest of the story of the torn jacket, as the jacket would not now be in my possession, nor should I now be writing to you, if it were not for a horse.

"The horse I was riding in the charge was in the studbook under the name of 'Cantharides,' and I bought him of Dick Bernard (whom Jack will remember), who had ridden him regularly with the Dublin Garrison Staghounds. When selling him to me Bernard said, 'It's a good thing to know, that if ever you want him to jump "big," you've only got to give him a little holloa the last stride before he takes off, and he'll understand you'.

"When we got to the guns the leading line (the I 7 th Lancers and ourselves) was terribly cut up, and the mere fact of passing through the guns and cutting down the men left with them broke us up still more. When we were fairly through them I found myself practically alone, but with some half-dozen of our men near me, all very busy with their swords on the drivers of the Russian artillery. I walked quietly on, singing out 'Rally I 3th,' and thinking more about getting some men together than anything else, when I suddenly found myself opposite to three Russian lancers coming towards me at a walk. Neither of us stopped till we were within a few yards of each other, and I. then saw that turning was out of the question, as one lancer was right in front of me and the other two were closing in on each flank. Fortunately for me, the man on my right wasn't quite in earnest, and only held out his lance instead of really using it. The man on my left meant business, and gave point savagely at my side, but I jerked my bridle-arm forward and turned the point of his lance clear of my body, the lance going through the sleeve of my jacket and shirt and making a red line across my arm, but doing no further damage. At the same moment the man in front attacked, and I saw that I couldn't pos- 
sibly parry it, and that unless I got out of the mess somehow I was done for. Dick Bernard's hint about the horse luckily occurred to me at the critical moment, and I gave the little holloa he spoke of. 'Cantharides' jumped at once, and down went both Russian and his horse. Meantime he had got his lance into my chest, but as the point hit on one of my ribs it only went in a very short way, and, in fact, I didn't suffer any inconvenience from it till the next day. After this performance the remaining Russians left me alone.

"If you think this long story about myself will bore the Colonel, pray don't read it to him, but put it quietly in the fire.

"With our very kind remembrances,

"Believe me,

"Sincerely yours,

"Percy Smith."

END OF VOL. I. 




\section{UNIVERSITY OF CALIFORNIA LIBRARY}

Los Angeles

This book is DUE on the last date stamped below.

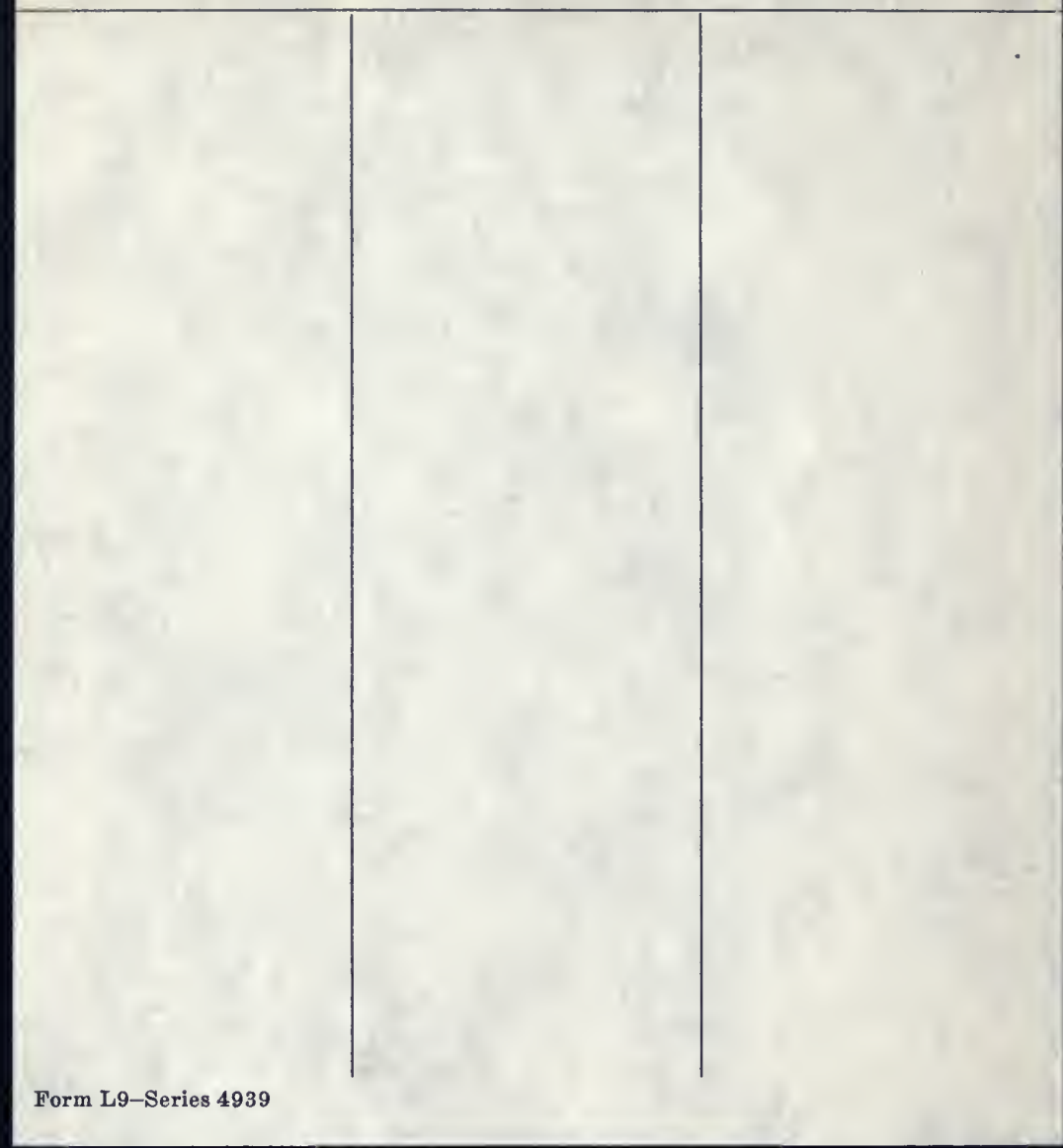




\section{PLEASE DO NOT REMOVE} THIS BOOK CARDE

(1)

$\sim$

-

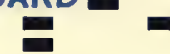

NHE.LIBRARYOOF.
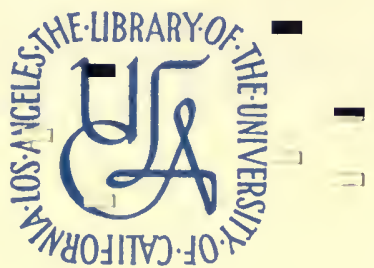

University Research Library
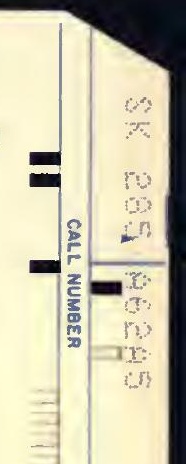
